

\section{INSTITUTO DE PESQUISAS ENERGÉTICAS E NUCLEARES}

Autarquia associada à Universidade de São Paulo

Avaliação de alternativas ao uso de níquel e cromatos no processo de fosfatização tricatiônico aplicado ao aço carbono

Rosele Correia de Lima Yamaguti

Tese apresentada como parte dos requisitos para obtenção do Grau de Doutor em Ciências na Área de Tecnologia Nuclear - Materiais

Orientadora:

Profa. Dra. Isolda Costa

São Paulo 


\section{DEDICATÓRIAS}

Dedico esta tese à minha família Alex, Luiza e

Vinicius, pela companhia, paciência e inspiração

sempre presentes.

Dedico também a todos meus familiares, em

Recife e São Paulo, que vislumbraram junto comigo a finalização desta importante etapa em minha vida.

"A natureza é o único livro que oferece um conteúdo valioso em todas as suas folhas" 


\section{AGRADECIMENTOS}

Durante o período dedicado ao desenvolvimento desta pesquisa, várias pessoas, de uma forma ou de outra, colaboraram no seu andamento e finalização. É de fato muito importante recordar de todos e agradecer pelo apoio nesta caminhada, mesmo que não seja possível aqui citar todos.

Agradeço a Deus primeiramente, por permitir, através das experiências vividas, meu desenvolvimento pessoal e profissional e possibilitar a conclusão deste desafio. Agradeço à Dra. Isolda Costa pela orientação deste trabalho e ao CNPq pelo apoio financeiro. Só para citar alguns nomes, agradeço aos colegas Antônio Carlos de Oliveira Sobrinho, Luiz Antonio Rossi Jazbinsek, Eurico Felix Pieretti, Olandir Vercino Corrêa e também ao Everson do Prado Banczek e Elki Cristina de Souza pelo auxílio e trocas de conhecimentos acadêmicos e profissionais e, a todos com quem convivi no IPEN. À Darlene Kobayashi e aos colegas do Centro Tecnológico da Marinha - SP, agradeço o apoio na finalização deste trabalho.

Agradeço a Companhia Brasileira de Metalurgia e Mineração (CBMM) pelas amostras cedidas de oxalato de nióbio e amônio, componente essencial da pesquisa,

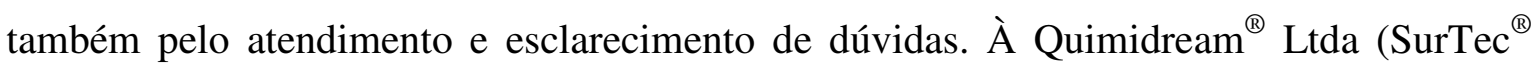
Ltda), que através do seu Consultor e Químico Anuar Gazal, forneceu ao laboratório vários componentes utilizados no processo de fosfatização. Agradecimentos também são devidos à indústria automotiva Mercedes-Benz em São Bernardo do Campo/SP, na pessoa do especialista em tratamento de superfícies Antônio Carlos O. Sobrinho e, pela cooperação no desenvolvimento da linha piloto de fosfatização agradeço a Bass Equipamentos Ltda, nas pessoas dos engenheiros Carlos e Cristian Maciel.

Agradeço a todos meus amigos, pelo incentivo sempre recebido. Com muito carinho quero registrar meu agradecimento a Dona Penha e Seu José Miklos, minha família aqui em São Paulo, por todos esses anos compartilhados. 


\title{
AVALIAÇÃO DE ALTERNATIVAS AO USO DE NÍQUEL E CROMATOS NO PROCESSO DE FOSFATIZAÇÃO TRICATIÔNICO APLICADO AO AÇO CARBONO
}

\author{
Rosele Correia de Lima Yamaguti
}

\begin{abstract}
RESUMO
Camadas de fosfato tricatiônico são largamente utilizadas na indústria automotiva como proteção contra corrosão e adesão de revestimentos orgânicos ao substrato de aço. A combinação do fosfato e revestimento proporciona à superfície metálica, alta durabilidade à corrosão. Porém a camada cristalina obtida com este tipo de fosfato apresenta poros entre os cristais, expondo o substrato metálico ao ambiente corrosivo, tornando importante um tratamento de passivação após fosfatização. O tratamento comercial de fosfatização tricatiônico e subsequente passivação envolvem o uso de elementos tóxicos, tais como níquel e cromo hexavalente, produzindo resíduos que são prejudiciais ao ambiente e seu uso têm sido cada vez mais proibido. O objetivo do presente estudo é investigar o efeito da troca do níquel, no processo de fosfatização, pelo composto de nióbio (oxalato de nióbio e amônio) com relação à resistência à corrosão do aço fosfatizado. Esta investigação foi realizada através de métodos eletroquímicos, utilizando-se principalmente ensaios de polarização potenciodinâmica e técnicas de espectroscopia de impedância eletroquímica (EIE); como também ensaios de névoa salina. Para caracterização superficial das camadas de fosfato foram adotadas, entre outras, as análises por microscopia eletrônica de varredura (MEV), espectroscopia de energia dispersiva (EDS) e difração de raios-X. Foram adotados dois tipos de banho de fosfato tricatiônico. Inicialmente utilizou-se uma composição de banho preparada em laboratório baseada em formulação usada por indústria de eletrodomésticos. Posteriormente foi adotado um banho com composição típica da indústria automotiva, especialmente preparado para estudos sem a presença do níquel. Os resultados dos testes eletroquímicos mostraram que a camada de fosfato obtida em solução contendo nióbio (zinco, manganês e nióbio) produziu melhor proteção contra corrosão do substrato, comparativamente àquela obtida em banho contendo níquel (zinco, manganês e níquel). O ensaio de névoa salina, por outro lado, sugeriu um desempenho similar com relação à corrosão para estes dois tipos de camadas de fosfato. $\mathrm{O}$ oxalato de nióbio e amônio parece apresentar um efeito de passivação mesmo quando usado em banhos de fosfatização. Mas como agente de passivação para aço carbono fosfatizado, os resultados apontaram para a necessidade de se realizar novas pesquisas.
\end{abstract}




\title{
EVALUATION OF ALTERNATIVES TO NICKEL AND CHROMATE IN THE TRICATIONIC PHOSPHATING PROCESS OF CARBON STEEL
}

\author{
Rosele Correia de Lima Yamaguti
}

\begin{abstract}
Tricationic phosphate layers are largely used in the automotive industry for corrosion protection and coatings adhesion to the steel substrate. The combination of phosphate and coating provides to the metallic surface long life protection against corrosion. The crystalline phosphate layer however presents porosities that exposes the metallic substrate to the corrosive environment and, consequently, a passivating treatment subsequent to phosphating is advisable. The commercial treatments of tricationic phosphating and subsequent passivation involve the use of toxic elements, such as nickel and hexavalent chromium, producing residues that are harmful to the environment and their use is being increasingly prohibited. The aim of the present study is to investigate the effect of replacement of nickel in the phosphating process by a niobium compound (ammonium niobium oxalate) on the corrosion resistance of the phosphated steel. The corrosion resistance evaluation of the phosphated steel was investigated by electrochemical methods, mainly polarization tests and electrochemical impedance spectroscopy (EIS), and salt spray tests. Characterization of the phosphate layer was also carried out by scanning electron microscopy (SEM), energy dispersive spectroscopy (EDS) and X-ray diffraction. Two types of tricationic phosphate baths were adopted. Initially, a laboratory prepared type based on the composition used in the electro domestic industry was utilized. Subsequently, another bath with a composition typical of the automotive industry, but specially prepared for this study with no nickel, was used. The results from electrochemical tests showed that the phosphate layer obtained in the niobium containing solution (zinc, manganese and niobium) produced better corrosion protection of the substrate comparatively to that produced in the nickel containing one (zinc, manganese and nickel). The salt spray tests, on the other hand, suggested similar corrosion performance for the samples with the two types of phosphate layers. The oxalate of niobium and ammonium seems to present a passivating effect when it is used in the phosphating bath. But to passivating effect the results pointed out to the need to carry out further research on the effect of niobium compound as a passivating agent for phosphated carbon steel.
\end{abstract}


1. INTRODUÇÃO

2. JUSTIFICATIVA E IMPORTÂNCIA DO TEMA .....................................................2

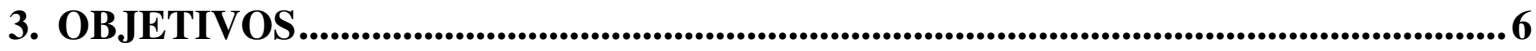

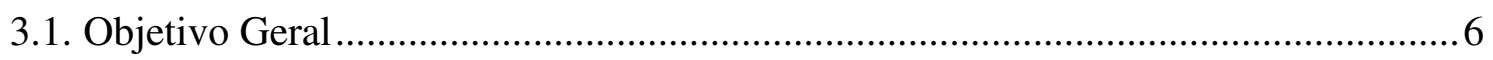

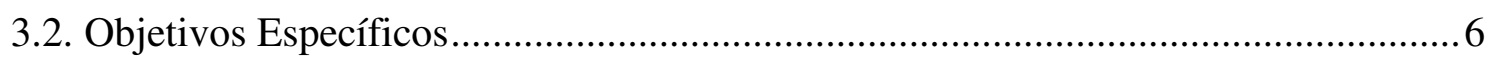

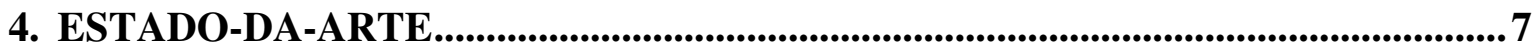

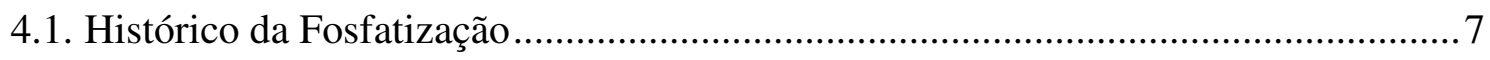

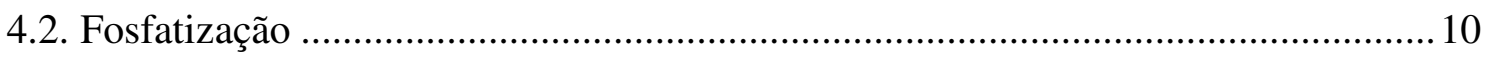

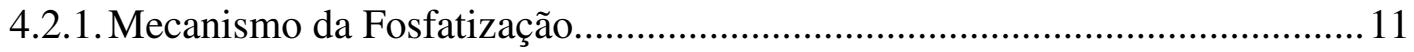

4.2.2. Aceleração do Processo de Fosfatizaçãa ........................................................ 16

4.2.3. Tipos e Propriedade dos Fosfatos ............................................................ 18

4.2.4. Processo de Fosfatização ........................................................................ 21

4.3. Aspectos Ambientais Ligados a Fosfatização..........................................................23

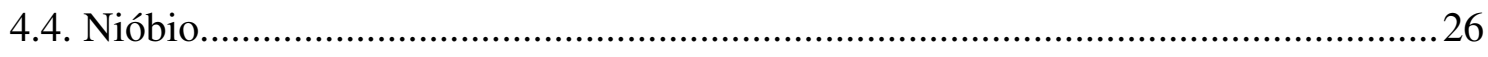

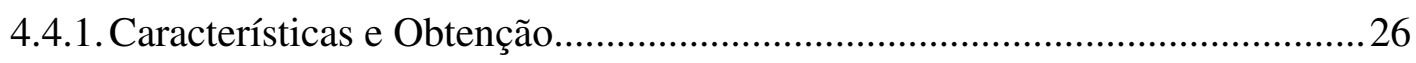

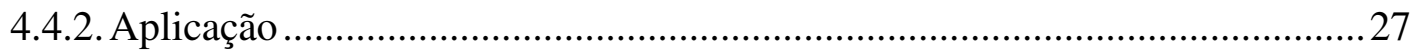

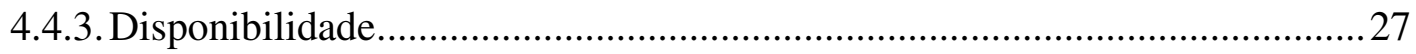

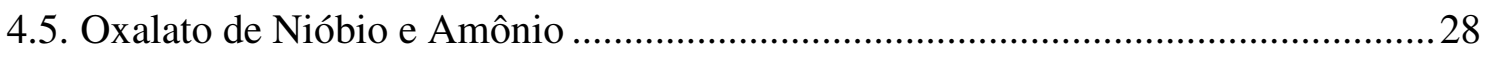

4.6. Passivação de Camadas Fosfatizadas...................................................................... 30

4.6.1. Cromo Hexavalente ............................................................................... 31

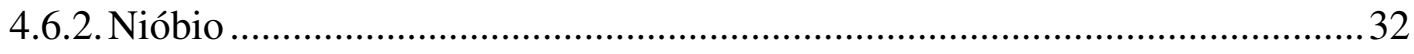

5. PROGRAMA EXPERIMENTAL .........................................................................34

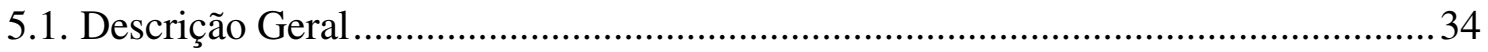

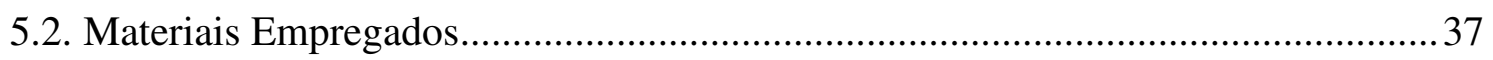

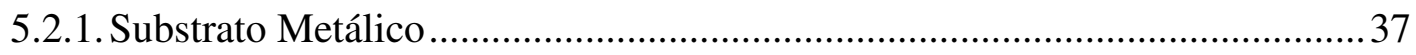

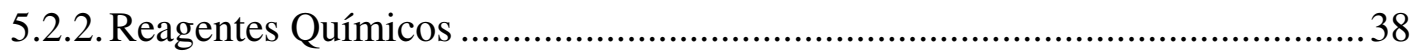

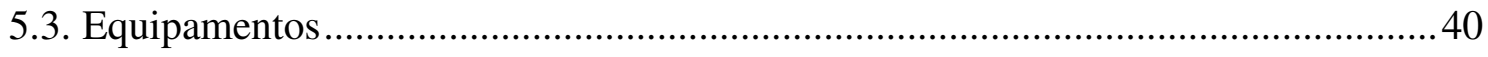

5.3.1. Dispositivo para Controle da Temperatura nos Banhos ............................... 40

5.3.2. Linha Piloto de Fosfatização .................................................................... 40

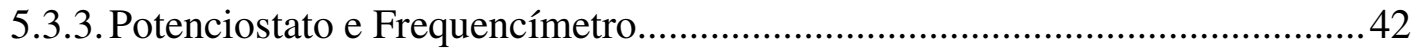


5.3.4. Células Eletroquímicas e Outros Acessórios 43

5.3.5. Microscópio Eletrônico de Varredura e Difratômetro de Raios-X.................. 44

5.3.6. Espectrômetro de Infravermelho ............................................................. 45

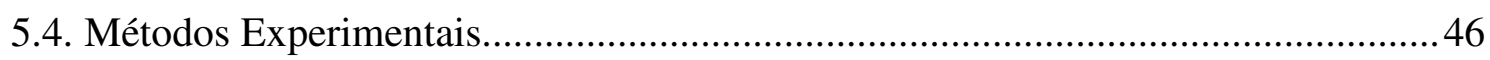

5.4.1. Elaboração das Soluções para Fosfatização ...................................................46

5.4.2. Padronização dos Banhos de Fosfatização (Ajuste da Acidez) ...................... 47

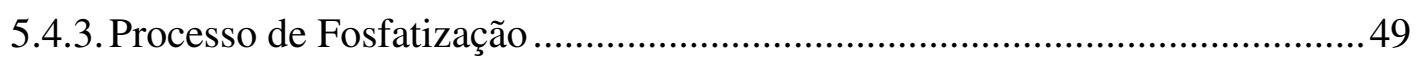

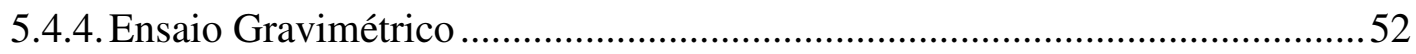

5.4.5. Desenvolvimento de Solução para Fosfatização Substituindo Níquel por

Composto de Nióbio...............................................................................53

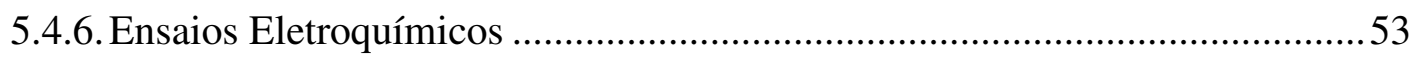

5.4.7. Caracterização Química e Morfológica das Camadas Fosfatizadas .................55

5.4.8. Passivação com Oxalato de Nióbio e Amônio .................................................56

5.4.9. Ensaio de Névoa Salina e Determinação da Aderência de Tintas ...................57

6. RESULTADOS OBTIDOS COM CONCENTRADO LABORATORIAL .............58

6.1 Definição das Condições de Fosfatização para o Banho Contendo Zn, Mn e Nb ....58

6.1.1. Ensaio Gravimétrico para Camada Obtida com Fosfato de Zn, Mn e Ni.......58

6.1.2. Micrografias por MEV das camadas de fosfato de $\mathrm{Zn}, \mathrm{Mn}$ e $\mathrm{Nb}$, com variação da concentração de $\mathrm{Nb}\left(5\right.$ e $\left.50 \mathrm{mg} . \mathrm{L}^{-1}\right)$

6.1.3.Micrografias por MEV do efeito da temperatura e concentração de $\mathrm{NaNO}_{2}$ na morfologia da camada de fosfato de zinco, manganês e nióbio.

6.1.4. Micrografias por MEV do efeito do tempo de imersão e da concentração de $\mathrm{NaNO}_{2}$ na morfologia da camada de fosfato de zinco, manganês e nióbio....65

6.2. Caracterização Superficial das Camadas de Fosfato Obtidas em Banhos com Base

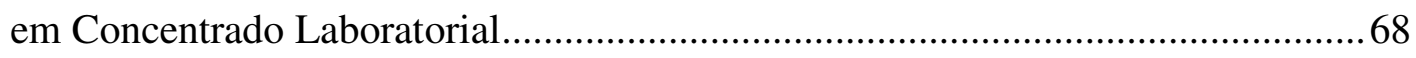

6.2.1. Microscopia Eletrônica de Varredura (MEV) das Camadas de Fosfato ........68

6.2.2. Determinação da Composição Química Elementar das Camadas de Fosfato 74

6.3. Avaliação Eletroquímica da Resistência à Corrosão de Aços com Tratamentos Selecionados de Fosfatização.............................................................................. 81

6.3.1. Espectroscopia de Impedância Eletroquímica (EIE) de Aços Fosfatizados... 81

6.3.2. Curvas de Polarização Potenciodinâmicas de Aços Fosfatizados .................. 83

7. CONSIDERAÇÕES PRELIMINARES.

8. RESULTADOS OBTIDOS COM CONCENTRADO INDUSTRIAL.......................86

8.1. Caracterização Superficial de Aços com Camadas de Fosfato Obtidas em Banhos com Base em Concentrado Industrial 
8.1.1.Ensaio Gravimétrico para as Camadas de Fosfato Obtidas em Banhos com Base em Concentrado Industrial 87

8.1.2. Microscopia Eletrônica de Varredura (MEV) de Aços com Camadas de Fosfato Obtidas em Banhos com Base em Concentrado Industrial. 88

8.1.3. Determinação da Composição das Camadas de Fosfato Obtidas em Banhos com Base em Concentrado Industrial ......................................................... 90

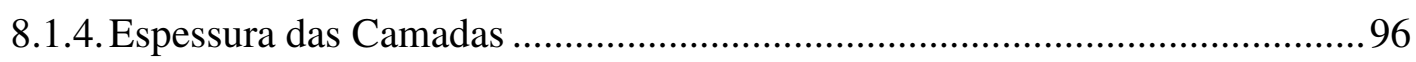

8.2. Avaliação Eletroquímica da Resistência à Corrosão das Camadas de Fosfato Obtidas em Banhos com Base em Concentrado Industrial 98

8.2.1. Espectroscopia de Impedância Eletroquímica de Aços com Camadas de Fosfato Obtidas em Banhos com Base em Concentrado Industrial. 98

8.2.2. Curvas de Polarização Potenciodinâmicas de Aços com Camadas de Fosfato Obtidas em Banhos com Base em Concentrado Industrial. 100

8.3. Resultado da Passivação com Oxalato de Nióbio e Amônio 104

8.4. Ensaio de Névoa Salina e Determinação da Aderência de Tintas 110

9. DISCUSSÃO DOS RESULTADOS 113

9.1 Proposta de Mecanismo para Atuação do Oxalato de Nióbio e Amônio Durante Fosfatização do Aço Carbono 116

10. CONCLUSÕES 118

11. PROPOSIÇÃO DE TEMAS PARA PESQUISAS FUTURAS 119

ANEXO A - Laudos da Análise do Aço. 120

ANEXO B - Projeto da Linha Piloto de Fosfatização. 123

REFERÊNCIAS BIBLIOGRÁFICAS. 


\section{LISTA DE TABELAS}

Tabela 1. Principais fases constituintes dos revestimentos de fosfato sobre Fe e $\mathrm{Zn} \mathrm{[32]} \mathrm{..} 15$

Tabela 2. Diferentes tipos de aceleradores usados em fosfatização [19]. 17

Tabela 3. Soluções de Fosfatização para substratos de ferro e aço carbono [14] 19

Tabela 4. Soluções de Fosfatização para substratos não ferrosos [14] 19

Tabela 5. Tipos e propriedades dos fosfatos mais utilizados [47] 20

Tabela 6. Resíduos nos quais pode estar contida a borra de fosfato [55] 24

Tabela 7. Impactos Ambientais e suas fontes na etapa de fosfatização [57] 25

Tabela 8. Algumas fontes comerciais disponíveis para $\mathrm{Nb}(\mathrm{V})$ [62] 29

Tabela 9. Resistência à corrosão dos principais tipos de revestimentos de fosfatos [14]....30

Tabela 10. Denominação dos banhos e camadas de fosfato utilizados neste trabalho .34

Tabela 11. Caracterização química de amostras de aço carbono .37

Tabela 12. Compostos químicos utilizados na pesquisa 39

Tabela 13. Composição da solução concentrada de fosfato tricatiônico com níquel 46

Tabela 14. Composição da solução concentrada de fosfato de zinco e manganês, base para preparo do banho tricatiônico com nióbio 47

Tabela 15. Padrões para a acidez livre e total para os fosfatos compostos por $\mathrm{Zn}, \mathrm{Mn}$ e Ni

Tabela 16. Banhos de fosfatização adotados neste trabalho 49

Tabela 17. Amostras e soluções adotadas nos testes de cronoamperometria 55

Tabela 18. Definição das amostras para o teste de névoa salina 57

Tabela 19. Condições testadas para o banho de fosfatização de $\mathrm{Zn}, \mathrm{Mn}, \mathrm{Nb}$. 61

Tabela 20. Absorções características no IR para camadas obtidas de fosfato tricatiônico.. 78

Tabela 21. Definição dos sistemas eletroquímicos analisados. 81

Tabela 22. Banhos de fosfato com base em concentrado industrial (ST617) 86 
Tabela 23. Análise semi-quantitativa da composição química por EDS das camadas de fosfato ST617 Zn,Mn,Ni e ST617 Zn,Mn+Nb ....................................................... 91

Tabela 24. Posição das bandas no espectro de infravermelho de revestimentos de fosfatos sobre aço galvanizado [39]

Tabela 25. Modos de vibração para as bandas encontradas nos fosfatos tricatiônicos de $\mathrm{Zn}, \mathrm{Mn}, \mathrm{Ni}$ e de $\mathrm{Zn}, \mathrm{Mn}$, Nb relacionados com os picos do espectro da Figura 52 .....94

Tabela 26. Valores de espessura, desvio padrão e médias para camadas de fosfatos com e sem tinta

Tabela 27. Efeito da adição do oxalato de nióbio e amônio no pH do eletrólito. 105 


\section{LISTA DE FIGURAS}

Figura 1. Dermatite causada pelo contato com níquel no solo [7]. 2

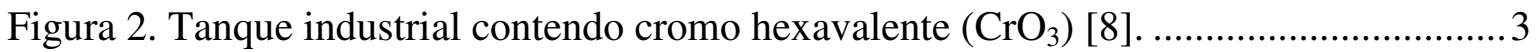

Figura 3. Exemplos de corrosão perfurante na carroceria de veículos automotores [10]......4

Figura 4. Distribuição dos custos diretos da corrosão nas diversas indústrias de transporte [11].

Figura 5. Representação das reações químicas geradas pelo ataque ácido na superfície metálica, de maneira genérica e para superfícies ferrosas.

Figura 6. Mecanismo simplificado de formação da camada de fosfato de zinco sobre aço carbono.

Figura 7. Identificação das etapas da fosfatização relacionadas à valores dos potenciais eletroquímicos medidos durante o processo: A - ataque eletroquímico; B - precipitação amorfa; B' - Dissolução do metal base; C - cristalização e crescimento; D reorganização cristalina [31]...

Figura 8. Ilustração e detalhes da estrutura cristalina da fosfofilita [33]............................ 15

Figura 9. Ilustração e detalhes da estrutura cristalina da hopeita [33] .............................. 15

Figura 10. Seqüência usual automatizada de fosfatização por imersão..............................23

Figura 11. Solubilidade do oxalato amoniacal de nióbio em função da temperatura [63]. . 29

Figura 12. Estrutura molecular básica do ânion oxalato de nióbio em que o átomo de nióbio é coordenado por 7 átomos de oxigênio e 2 grupos oxalatos [63] .................................30

Figura 13. Diagrama de equilíbrio potencial-pH para o sistema $\mathrm{Nb}-\mathrm{H}_{2} \mathrm{O}$, a $25{ }^{\circ} \mathrm{C}$ [73]. .... 32

Figura 14. Fluxograma do desenvolvimento inicial da pesquisa...................................... 36

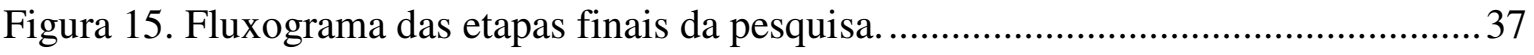

Figura 16. Dispositivo para controle de temperatura nos banhos de fosfatização................40

Figura 17. Linha piloto de fosfatização ........................................................................ 41

Figura 18. Projeto da linha piloto de fosfatização - vista frontal (dimensões em mm) ......41 
Figura 19. Projeto da linha piloto de fosfatização - vista superior e perspectiva isométrica do tanque interno (dimensões em $\mathrm{mm}$ )...................................................................42

Figura 20. Potenciostato e frequencímetro conectados a microcomputador 42

Figura 21. Foto da célula eletroquímica "flat cell" (a) montada, mostrando locais para os eletrodos de trabalho e de referência. (b) desmontada, mostrando orifícios e anel de vedação

Figura 22. Célula eletroquímica com área de exposição da amostra na parte inferior, área circular igual a $1,0 \mathrm{~cm}^{2}$. Utilizada para ensaios de curta duração.

Figura 23. (a) Eletrodo de referência da Analyser® $\mathrm{Ag} / \mathrm{AgCl}$; (b) Contra-eletrodo de platina ( $\phi=1 \mathrm{~mm}$ e $\mathrm{L}=750 \mathrm{~mm}$ ). Utilizados para os dois tipos de células.

Figura 24. (a) Equipamento de difração de raios-X. (b) Microscópio eletrônico de varredura

Figura 25. Espectrômetro de infravermelho 45

Figura 26. Ilustração da seqüência de fosfatização tricatiônica adotada 52

Figura 27. Equipamento utilizado (Fischer) para estimativa da espessura dos revestimentos .56

Figura 28. Variação de massa de fosfato em função do tempo de imersão no banho de fosfatização de Zn, Mn e Ni. 59

Figura 29. Micrografias por MEV da superfície do aço após imersão por 5 minutos em banho de fosfato tricatiônico ( $\mathrm{Zn}, \mathrm{Mn}, \mathrm{Nb}$ ), com teor de $\mathrm{Nb}$ de (a) $5 \mathrm{mg} . \mathrm{L}^{-1}$ e (b) 50 mg. $\mathrm{L}^{-1}$

Figura 30. Camadas de fosfato de $\mathrm{Zn}, \mathrm{Mn}$ e $\mathrm{Nb}\left(5 \mathrm{mg} . \mathrm{L}^{-1}\right)$ obtidas para 3 minutos de imersão em banho de fosfato com várias concentrações de $\mathrm{NaNO}_{2}$ a $25^{\circ} \mathrm{C}$ e $50{ }^{\circ} \mathrm{C} \ldots 62$

Figura 31. Camadas de fosfato de $\mathrm{Zn}, \mathrm{Mn}$ e $\mathrm{Nb}\left(5 \mathrm{mg} . \mathrm{L}^{-1}\right)$ obtidas para 5 minutos de imersão em banho de fosfato com várias concentrações de $\mathrm{NaNO}_{2}$ a $25^{\circ} \mathrm{C}$ e $50{ }^{\circ} \mathrm{C} \ldots 63$

Figura 32. Superfícies do aço fosfatizado em banho de $\mathrm{Zn}, \mathrm{Mn}$ e $\mathrm{Nb}\left(5 \mathrm{mg} . \mathrm{L}^{-1}\right)$ a $25^{\circ} \mathrm{C}$ com várias concentrações de $\mathrm{NaNO}_{2}$, para 3 e 5 minutos de imersão.

Figura 33. Superfície do aço fosfatizado em banho de $\mathrm{Zn}, \mathrm{Mn}$ e $\mathrm{Nb}\left(5 \mathrm{mg} . \mathrm{L}^{-1}\right)$ a $50{ }^{\circ} \mathrm{C}$ com várias concentrações de $\mathrm{NaNO}_{2}$, para 3 e 5 minutos de imersão..

Figura 34. Micrografia obtida por MEV da superfície do aço carbono sem revestimento..68

Figura 35. Micrografias por MEV de camada de fosfato tricatiônico de Zn, Mn e Ni, obtido para 5 minutos em banho com $0,5 \mathrm{~g} . \mathrm{L}^{-1}$ de $\mathrm{NaNO}_{2}$, a $25^{\circ} \mathrm{C}$. (a) Aumento menor mostrando regiões de baixa cobertura do substrato e (b) maior aumento mostrando a morfologia dos cristais 
Figura 36 (a) e (b). Micrografias por MEV de camada de fosfato tricatiônico de Zn, Mn e $\mathrm{Nb}$, obtido para 5 minutos em banho com 2,0 g.L $\mathrm{L}^{-1}$ de $\mathrm{NaNO}_{2}$, a $25^{\circ} \mathrm{C}$....................... 70

Figura 37 (a) e (b). Micrografias por MEV de camada de fosfato tricatiônico de Zn, Mn e $\mathrm{Nb}$, obtido para 3 minutos em banho com 2,0 g. $\mathrm{L}^{-1}$ de $\mathrm{NaNO}_{2}$, a $50{ }^{\circ} \mathrm{C}$...................... 71

Figura 38 (a) e (b). Micrografias por MEV de camada de fosfato de Zn e Mn obtida para 5 minutos de imersão em banho com 2,0 g. $\mathrm{L}^{-1}$ de $\mathrm{NaNO}_{2}$, a $25^{\circ} \mathrm{C}$

Figura 39 (a) e (b). Micrografias por MEV de camada de fosfato de Zn e Mn obtida para 3 minutos de imersão em banho com 2,0 g. $\mathrm{L}^{-1}$ de $\mathrm{NaNO}_{2}$, a $50{ }^{\circ} \mathrm{C}$................................ 74

Figura 40 (a) - (f). Espectros obtidos por EDS da superfície do aço carbono, sem e com vários tipos de camadas de fosfato.

Figura 41. Espectros de infravermelho das camadas de fosfato de Zn, Mn e Ni; Zn, Mn, Nb e Zn, Mn, obtidas para diferentes condições de temperatura e tempo de imersão. .......77

Figura 42. Espectros de infravermelho das camadas de fosfato de $\mathrm{Zn}, \mathrm{Mn}$ e Ni em relação às camadas de $\mathrm{Zn}, \mathrm{Mn}, \mathrm{Nb}$ e de $\mathrm{Zn}, \mathrm{Mn}$ à $25^{\circ} \mathrm{C}$ por 5 minutos de imersão. .78

Figura 43 (a) - (d). Difratogramas de raios- $\mathrm{X}$ do aço carbono sem revestimento e com camadas distintas de fosfato. (1) $\mathrm{Zn}_{2} \mathrm{Fe}\left(\mathrm{PO}_{4}\right)_{2}\left(\mathrm{H}_{2} \mathrm{O}\right)_{4}$ (fosfofilita); (2) $\mathrm{Zn}_{3}\left(\mathrm{PO}_{4}\right)_{2}\left(\mathrm{H}_{2} \mathrm{O}\right)_{4}$ (hopeita); (3) Fe (ferro).

Figura 44. Diagramas de Nyquist para amostras de aço carbono 1005 sem revestimento e revestidas com fosfatos tricatiônicos, ensaiadas em solução de 0,5 mol.L $\mathrm{L}^{-1}$ de $\mathrm{NaCl} . .82$

Figura 45. Diagramas de ângulo de fase de Bode para amostras de aço carbono 1005 sem revestimento e revestidas com fosfatos tricatiônicos, ensaiadas em solução de 0,5 mol. $\mathrm{L}^{-1}$ de $\mathrm{NaCl}$.

Figura 46. Curvas de polarização potenciodinâmicas catódicas para o aço carbono sem e com revestimentos de fosfatos..... 84

Figura 47. Curvas de polarização potenciodinâmicas anódicas para o aço carbono sem e com revestimentos de fosfatos

Figura 48. Variação de massa de fosfato em função do tempo de imersão no banho de fosfatização de $\mathrm{Zn}$, Mn e Ni e de $\mathrm{Zn}, \mathrm{Mn}$ e Nb .....

Figura 49. Micrografias obtidas por MEV do revestimento de fosfato composto por $\mathrm{Zn}, \mathrm{Mn}$ e Ni (imersão por 5 minutos, com 0,3 g. $\mathrm{L}^{-1}$ de $\mathrm{NaNO}_{2}$, a $50{ }^{\circ} \mathrm{C}$ )

Figura 50. Micrografias obtidas por MEV do revestimento de fosfato composto por $\mathrm{Zn}, \mathrm{Mn}$ e $\mathrm{Nb}$ (imersão por 5 minutos, com 1,0 g. $\mathrm{L}^{-1}$ de $\mathrm{NaNO}_{2}$, a $50{ }^{\circ} \mathrm{C}$ ) 90

Figura 51. Espectros obtidos por EDS da superfície do aço com revestimento de fosfato .91 
Figura 52. Espectros de fosfatos tricatiônicos obtidos por espectroscopia de infravermelho. (a) Intervalo entre $500 \mathrm{~cm}^{-1}$ a $4000 \mathrm{~cm}^{-1}$. (b) Ampliação do espectro para o intervalo entre $500 \mathrm{~cm}^{-1} \mathrm{e} 1200 \mathrm{~cm}^{-1}$

Figura 53. Estrutura molecular do fosfato.

Figura 54. Difratograma de raios-X do aço carbono com revestimentos de fosfato tricatiônico ( $\mathrm{Zn}, \mathrm{Mn}, \mathrm{Nb}$ ) onde (1) fosfofilita, (2) hopeita e (3) ferro. 95

Figura 55. Difratograma de raios- $X$ padrão para revestimento de fosfato de zinco em substrato de aço zincado [81] 96

Figura 56. Diagramas de Nyquist para amostras de aço carbono 1005 com camada de fosfato de $\mathrm{Zn}$, Mn e $\mathrm{Ni}$ obtida a $50{ }^{\circ} \mathrm{C}$ durante 5 minutos de imersão. Ensaios realizados em meio de $0,5 \mathrm{~mol} \mathrm{~L}^{-1}$ de $\mathrm{NaCl}$, após $2 \mathrm{~h}$ de imersão.

Figura 57. Diagramas de Nyquist para amostras de aço carbono 1005 com camada de fosfato de $\mathrm{Zn}, \mathrm{Mn}$ e $\mathrm{Nb}$ obtida a $50{ }^{\circ} \mathrm{C}$ durante 5 minutos de imersão. Ensaios realizados em meio de $0,5 \mathrm{~mol} \mathrm{~L}^{-1}$ de $\mathrm{NaCl}$, após $2 \mathrm{~h}$ de imersão.

Figura 58. Diagramas de ângulo de fase de Bode para amostras de aço carbono 1005 com camadas de fosfato de $\mathrm{Zn}, \mathrm{Mn}, \mathrm{Nb}$ e $\mathrm{Zn}, \mathrm{Mn}$, Ni obtidas a $50^{\circ} \mathrm{C}$ durante 5 minutos de imersão. Ensaios realizados em meio de $0,5 \mathrm{~mol} \mathrm{~L}^{-1} \mathrm{de} \mathrm{NaCl}$, após $2 \mathrm{~h}$ de imersão. ...99

Figura 59. Curvas de polarização potenciodinâmicas anódicas (a) e catódicas (b) para o aço carbono com revestimento de $\mathrm{Zn}$, Mn e $\mathrm{Nb}$. Ensaios realizados para 3 horas de imersão em meio de 0,5 mol. $\mathrm{L}^{-1}$ de $\mathrm{NaCl}$.

Figura 60. Curvas de polarização potenciodinâmicas anódicas (a) e catódicas (b) para o aço carbono com revestimento de Zn, Mn e Ni. Ensaios realizados para 3 horas de imersão em meio de 0,5 mol. $\mathrm{L}^{-1}$ de $\mathrm{NaCl}$. 102

Figura 61. Curvas de polarização potenciodinâmicas anódicas (a) e catódicas (b) de aços fosfatizados em banhos de $\mathrm{Zn}, \mathrm{Mn}, \mathrm{Ni} ; \mathrm{Zn}, \mathrm{Mn}, \mathrm{Nb}$ e tricatiônico industrial. Ensaios realizados para 3 horas de imersão em meio de 0,5 mol. $\mathrm{L}^{-1}$ de $\mathrm{NaCl}$ 103

Figura 62. Curvas cronoamperométricas de aços fosfatizados em banho de $\mathrm{Zn}, \mathrm{Mn}$ e $\mathrm{Nb}$ imersos em soluções tamponadas com e sem nióbio $\left(200 \mathrm{mg} \cdot \mathrm{L}^{-1}\right)$. (a) Soluções tampão originalmente com pH 6. (b) Soluções tampão originalmente com pH 8. Comparadas à passivação em solução de cromo hexavalente $(\mathrm{pH} 4)$ 105

Figura 63. Curvas cronoamperométricas de aços fosfatizados em banho de $\mathrm{Zn}, \mathrm{Mn}$ e $\mathrm{Nb}$ imersos em soluções tamponadas com e sem nióbio (400 mg. $\mathrm{L}^{-1}$ ). (a) Soluções tampão originalmente com pH 6. (b) Soluções tampão originalmente com pH 8. Comparadas à passivação em solução de cromo hexavalente (pH 4)

Figura 64. Curvas de polarização anódicas e catódicas do aço fosfatizado ( $\mathrm{Zn}, \mathrm{Mn}$ e $\mathrm{Nb}$ ) e passivado em soluções com $\mathrm{Nb}$ ou $\mathrm{CrO}_{3}$. Resultados obtidos em solução $0,2 \mathrm{~mol} \mathrm{~L}^{-1}$ $\mathrm{NaCl}$ 
Figura 65. Resultados de EIE: (a) Diagramas de Nyquist e (b) Diagramas de ângulo de fase de Bode de aço fosfatizado ( $\mathrm{Zn}, \mathrm{Mn}$ e $\mathrm{Nb}$ ) e passivado em soluções com composto de $\mathrm{Nb}$ ou $\mathrm{CrO}_{3}$. Resultados obtidos em solução 0,2 mol.L $\mathrm{L}^{-1} \mathrm{NaCl}$ após $2 \mathrm{~h}$ de imersão.. 109

Figura 66. Placas de aço sem revestimento e fosfatizadas em banhos tricationnicos 110

Figura 67. Placas de aço fixadas em cabine antes da pintura por imersão e revestidas com tinta eletroforética após pintura e secagem

Figura 68. Placas após 504 horas em câmara de névoa salina, segundo norma ASTM B117. (a) Aço sem revestimento, com tinta eletroforética. (b) Aço com fosfato de Zn, Mn, Ni e tinta eletroforética. (c) Aço com fosfato de Zn, Mn, Nb e tinta eletroforética

Figura 69. Resultado do ensaio de aderência, após corrosão por névoa salina, segundo norma NBR 11003/2009. (a) Aço sem revestimento, com tinta eletroforética. (b) Aço com fosfato de $\mathrm{Zn}, \mathrm{Mn}$, Ni e tinta eletroforética. (c) Aço com fosfato de $\mathrm{Zn}, \mathrm{Mn}, \mathrm{Nb}$ e tinta eletroforética 112

Figura 70. Amostras de aço apresentando revestimento não uniforme de fosfato de $\mathrm{Zn}, \mathrm{Mn}$ e $\mathrm{Nb}$ aplicado à $58^{\circ} \mathrm{C}$ por 5 minutos, com $1 \mathrm{~g} . \mathrm{L}^{-1}$ de $\mathrm{NaNO}_{2}$ 114

Figura 71. Micrografias por MEV (imagens por elétrons retroespalhados) de camada de fosfato de $\mathrm{Zn}, \mathrm{Mn}$ e $\mathrm{Nb}$, obtida por 5 minutos de imersão a $58{ }^{\circ} \mathrm{C}$, apresentando 3 regiões distintas, referenciadas na Figura 70. A1) região azulada. A2) região pouco recoberta. A3) região melhor recoberta.

Figura 72. Espectros obtidos por EDS de camada de fosfato de $\mathrm{Zn}$, Mn e $\mathrm{Nb}$ obtida por 5 minutos de imersão a $58{ }^{\circ} \mathrm{C}$, apresentando 3 regiões distintas referenciadas na Figura 70. A1) região azulada. A2) região pouco recoberta. A3) região melhor recoberta... 115

Figura 73. Representação esquemática de proposta para atuação do oxalato de nióbio e amônio em banho de fosfatização tricatiônico, tanto na nucleação de cristais como na passivação superficial de áreas do substrato metálico exposto 116 


\section{INTRODUÇÃO}

A fosfatização é um processo bem antigo, com registros de patente desde o ano de 1869 [1]. O processo de fosfatização tricatiônico é um tratamento de superfície em metais bastante utilizado na melhoria da aderência entre a superfície metálica e os revestimentos de pintura, proporcionando também um aumento da durabilidade do sistema à corrosão. Este processo é adotado principalmente por indústrias automobilísticas, tendo em sua composição normalmente cátions de zinco, níquel e manganês.

Normalmente, as indústrias que utilizam processos de fosfatização têm em suas plantas as instalações necessárias para execução destes, porém adquirem de indústrias químicas os componentes concentrados para as diversas etapas que envolvem a fosfatização. Devido à necessidade de um controle rigoroso nas diversas fases do processo, é comum o acompanhamento de cada etapa por técnicos especializados, coletando amostras, quando necessário, para confirmação da qualidade do revestimento obtido.

Desta forma, esse processo, demanda altos custos para garantia da durabilidade à corrosão das peças metálicas, envolvendo em sua formulação componentes que hoje, sob a ótica ambiental, são danosos ao meio ambiente ou, diretamente, à saúde humana.

Este trabalho investiga alternativas visando a possibilidade da substituição do níquel (Ni) presente em banhos de fosfatização tricatiônico, assim como a troca do cromo hexavalente $\left(\mathrm{CrO}_{3}\right)$, tradicionalmente utilizado como proteção passiva das camadas fosfatizadas. O estudo abrangeu a substituição de ambos, Ni no banho de fosfatização e $\mathrm{CrO}_{3}$, como passivador da superfície fosfatizada, por composto a base de nióbio, visto que este elemento não apresenta restrições ambientais.

Em 2008, BANCZEK [2] apresentou resultados promissores de estudos relacionados ao uso de compostos de nióbio em banhos de fosfato de zinco em substituição ao níquel. Em continuidade à pesquisa com fosfato de zinco, o presente trabalho apresenta resultados de estudos relativos à substituição do níquel por composto de nióbio em banhos de fosfato tricatiônico, bem como o efeito deste composto na passivação da superfície fosfatizada. 


\section{JUSTIFICATIVA E IMPORTÂNCIA DO TEMA}

Dois pontos são relevantes quanto às pesquisas com fosfatização, a saber: Primeiro o aspecto ambiental e de saúde humana advindo dos produtos e processos que envolvem a elaboração e uso dos banhos de fosfatização e, em segundo, questões relativas a aspectos econômicos advindos dos problemas gerais acarretados pela corrosão metálica.

Os problemas ambientais resultantes da fosfatização são relativos principalmente à presença de níquel e do cromo hexavalente utilizados em seu processo, a geração de resíduo, descarte e tratamento deste.

Os riscos de contaminação pelo níquel nos banhos industriais de fosfatização estão relacionados ao preparo e manuseio destas soluções e na destinação final do resíduo de fosfatização, devido ao risco de inalação e contato com a pele ou olhos [3]. Estudos realizados pela Agência Internacional de Pesquisa em Câncer (IARC) demonstraram que o níquel é carcinogênico [4]. Alguns compostos apresentam maior risco, conforme classificação da Agência de Proteção Ambiental Americana (EPA/USA). Segundo a EPA, a poeira de refinaria e o sulfato de níquel fazem parte do Grupo A, referente a compostos carcinogênicos em pessoas. Já a carbonila de níquel faz parte do Grupo B2, relativo a compostos provavelmente carcinogênicos em pessoas [5].

Como fontes principais de níquel para o meio ambiente, citam-se a queima de combustíveis fósseis, os processos de mineração e fundição do metal, fusão e modelagem de ligas, e indústrias de eletrodeposição. Doses elevadas de níquel podem causar dermatites nos indivíduos com sensibilidade a este metal (Figura 1), bem como afetar nervos cardíacos e respiratórios [6].

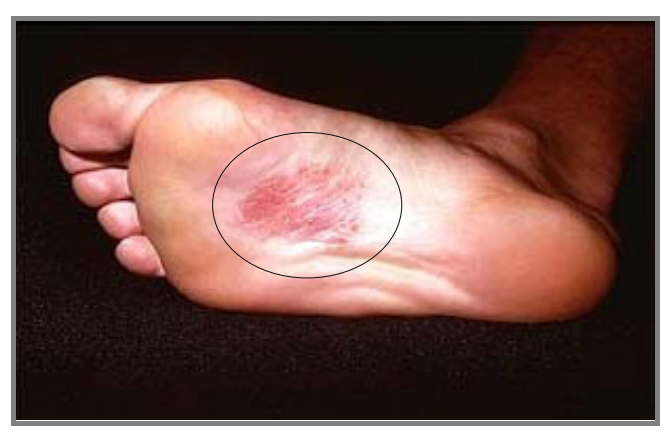

Figura 1. Dermatite causada pelo contato com níquel no solo [7]. 
O uso do cromo hexavalente no processo de fosfatização ocorre na etapa de passivação. Esta etapa tem por finalidade recobrir o substrato metálico, selando os poros existentes na camada de fosfato. $\mathrm{O}$ cromo hexavalente $\left(\mathrm{CrO}_{3}\right)$ é reconhecidamente cancerígeno, mas ainda é adotado em processos por algumas indústrias.

O Instituto Nacional para Saúde e Segurança Ocupacional - NIOSH (USA) considera todos os compostos a base de $\mathrm{CrO}_{3}$ como potenciais carcinogênicos ocupacionais [8]. Milhões de trabalhadores ao redor do mundo estão expostos à fumaça, névoas e poeiras no ar contendo cromo ou seus compostos. Das situações de trabalho em que ocorre a exposição ao cromo hexavalente, as mais frequentes são durante a produção de cromato, soldagem, fabricação de pigmentos cromados, cromagem e pintura spray [4], assim como em banhos de tratamento superficiais contendo cromo hexavalente em processos industriais, conforme ilustrado na Figura 2 [8].

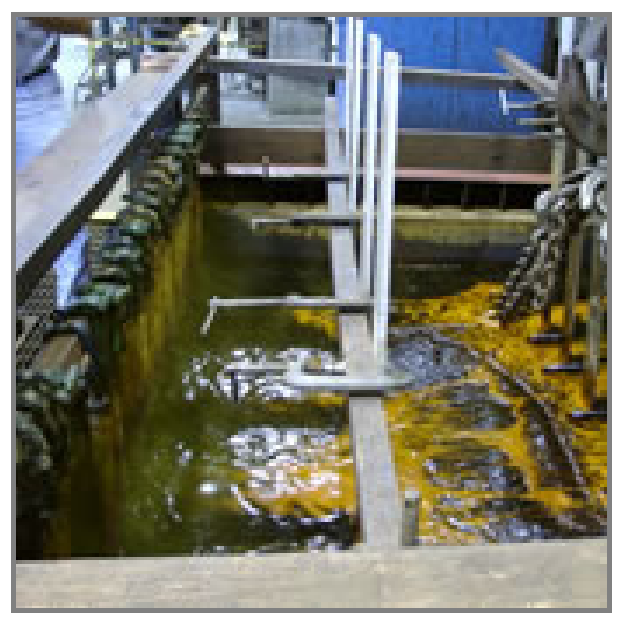

Figura 2. Tanque industrial contendo cromo hexavalente $\left(\mathrm{CrO}_{3}\right)[8]$.

A principal exposição ocupacional ao níquel é via inalação. Fontes não ocupacionais de exposição ao cromo hexavalente incluem alimentos, ar e água; mas os níveis são geralmente bem mais baixos do que os normalmente encontrados em situações ocupacionais [4]. Efeitos adversos à saúde associados com a exposição ao $\mathrm{CrO}_{3}$ incluem dermatites, úlceras na pele, alergias de contato, asma ocupacional, rinites, câncer nasal, irritação nos olhos e edema pulmonar, entre outros [8].

A fosfatização como tratamento de superfície, visa, entre outros efeitos, o aumento da resistência à corrosão das peças metálicas. Porém, sua principal importância não decorre de suas propriedades intrínsecas, mas de seus efeitos secundários [9]. A cobertura de fosfato sobre o aço pode aumentar sua resistência contra a corrosão, mas não 
significativamente como indica GENTIL [9], que mostra que a fosfatização combinada com revestimentos (tinta) representa grande aumento na durabilidade de peças e componentes metálicos expostos à corrosão atmosférica.

Muito comum há décadas, a corrosão perfurante costumava surgir em carros com mais de cinco anos de vida útil, podendo ocorrer mais cedo nos veículos expostos às regiões litorâneas (Figura 3) [10]. Com a evolução do tratamento dos componentes metálicos e sistema de pintura, este tipo de problema de corrosão foi ultrapassado.

Apesar dos avanços, um levantamento realizado entre 1999 e 2001 nos Estados Unidos, pela CC Technologies Laboratories Inc. com suporte da FHWA e NACE ${ }^{1}$, apresentou como custos diretos da corrosão na indústria de transporte o valor de US\$ 29,7 bilhões, sendo que US\$ 23,4 bilhões (ou 79\%) destes são relativos a veículos automotores (Figura 4) [11].

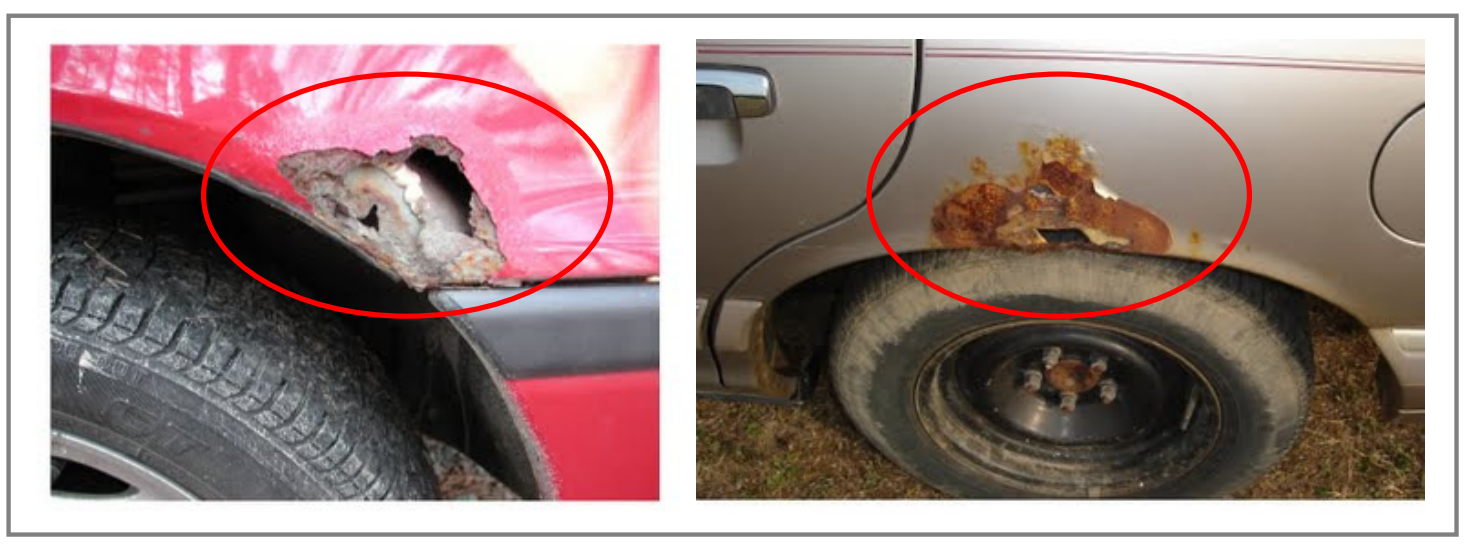

Figura 3. Exemplos de corrosão perfurante na carroceria de veículos automotores [10].

\footnotetext{
${ }^{1}$ FHWA - Administração Federal de Auto-estradas nos Estados Unidos. NACE International - Organização Americana dedicada ao estudo da corrosão.
} 


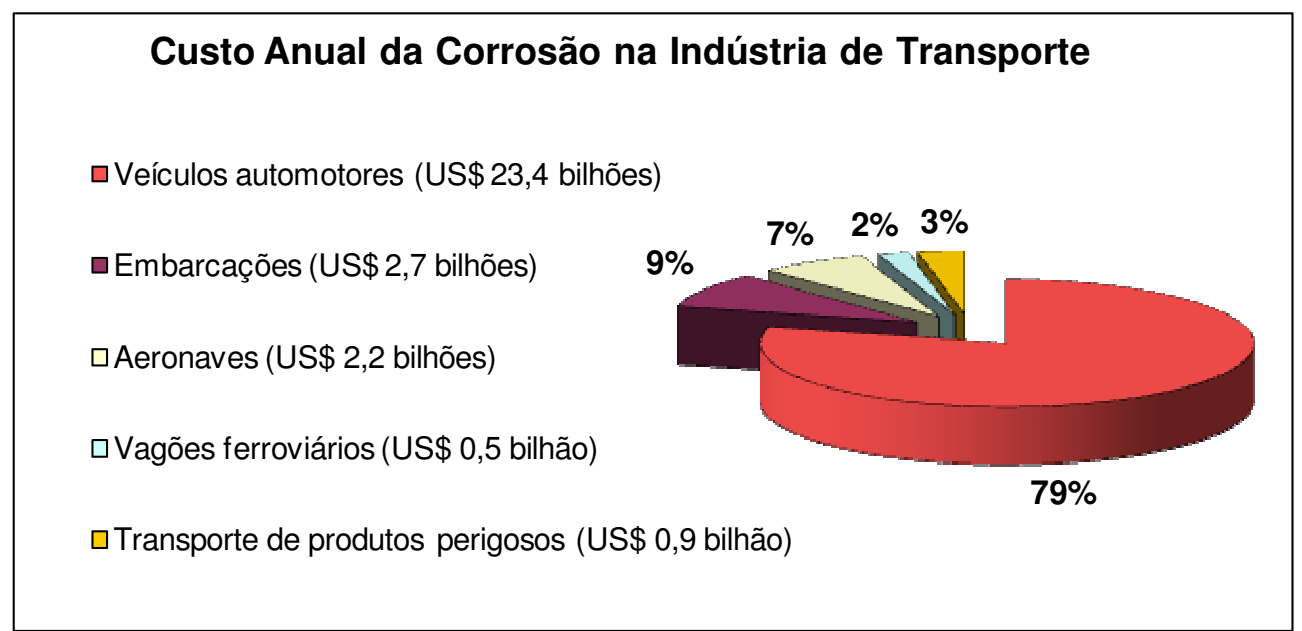

Figura 4. Distribuição dos custos diretos da corrosão nas diversas indústrias de transporte [11]

Neste estudo, os custos definidos como diretos, envolveram gastos assumidos por proprietários e administradores de estruturas, fabricantes de produtos e fornecedores de serviços. Os custos ditos indiretos envolvem gastos com perda de produtividade, superdimensionamento de projetos para evitar a corrosão, entre outros $[11,12]$.

Com base no levantamento realizado nos Estados Unidos [11], a ABRACO (Associação Brasileira de Corrosão) apresentou como custo total (direto e indireto) anual da corrosão no Brasil o montante de $3 \%$ do PIB $^{2}$ ou US\$ 6,3 bilhões. Salientando que, com a adoção de práticas de controle e combate a corrosão, pode ser economizado anualmente $1 \%$ do PIB ou cerca de US\$ 2 bilhões [13].

Em vista do exposto, o presente trabalho tem grande importância na medida em que visa suprir a necessidade ambiental da substituição do níquel e de cromatos na produção industrial. Além disso, representa uma contribuição na área da fosfatização tricatiônica, a qual é de grande relevância para a durabilidade de peças metálicas e produtos industrializados.

O presente trabalho apresenta, como originalidade, o desenvolvimento de uma nova composição de banho de fosfatização tricatiônica, nunca estudada previamente, contendo zinco, manganês e composto de nióbio, o que confere a esta pesquisa seu caráter de ineditismo.

\footnotetext{
${ }^{2}$ Em 2010, o PIB variou 7,5\% e ficou em R \$ 3,675 trilhões. Ou US\$ 2,09 trilhões, considerando o dólar a um valor médio de US\$1,76, em 2010.

http://www.ibge.gov.br/home/presidencia/noticias/noticia_visualiza.php?id_noticia=1830\&id_pagina=1.
} 


\section{OBJETIVOS}

Os objetivos gerais e específicos do presente trabalho são os seguintes:

\subsection{Objetivo Geral}

- Investigar a potencialidade de substituição do níquel por composto de nióbio, em banhos de fosfato tricatiônico, compostos originalmente por zinco, manganês e níquel, e estudar o efeito da substituição da passivação com cromo hexavalente pelo tratamento com este mesmo composto de nióbio e amônio na resistência à corrosão do aço fosfatizado, buscando atender às necessidades de soluções ambientalmente sustentáveis.

\subsection{Objetivos Específicos}

- Investigar e comparar o comportamento eletroquímico em meio de $\mathrm{NaCl}$ 0,5 mol.L $\mathrm{L}^{-1}$, de amostras de aço carbono fosfatizadas em banhos de fosfato tricatiônico; não passivadas e passivadas em soluções contendo cromo hexavalente ou composto de nióbio.

- Caracterizar físico-quimicamente as camadas de fosfato tricatiônico de zinco, manganês e níquel e de zinco, manganês e nióbio.

- Comparar a resistência à corrosão de amostras fosfatizadas nos banhos de Zn, $\mathrm{Mn}, \mathrm{Ni}$ e de $\mathrm{Zn}, \mathrm{Mn}$, Nb revestidas com tinta, através de ensaio de corrosão acelerada em câmaras de névoa salina. 


\section{ESTADO-DA-ARTE}

\subsection{Histórico da Fosfatização}

A fosfatização é o processo mais comumente usado para pré-tratamento de aços. A primeira patente para este processo foi obtida em 1869 por W. A. Ross ${ }^{3}$, onde seu procedimento consistiu em imergir peças metálicas quentes em ácido fosfórico, obtendo uma melhora na resistência a corrosão das peças [1, 14].

Em 1879, A. B. Brown e W. P. Brown propuseram um procedimento onde as peças de ferro, previamente aquecidas, eram imersas em uma solução de fosfato monoácido de sódio e amônio. Apesar de apresentar melhoras com relação à proteção contra corrosão, ainda eram procedimentos que não apresentavam uma proteção adequada, devido às camadas formadas serem muito finas [14].

Entre 1906 e 1925, Thomas W. Coslett ${ }^{4}$ obteve uma série de patentes nas quais descrevia um procedimento de fosfatização de metais ferrosos, imergindo peças em solução quase fervente de ácido fosfórico. Para reduzir a acidez livre e a violenta reação inicial do metal com o ácido, propôs a adição de aparas do mesmo metal. Neste período já se definiu o fosfato de zinco como opção ao pré-tratamento de pintura $[1,14]$.

Os trabalhos desenvolvidos por Coslett resultaram em descobertas bem conhecidas e atualmente em uso. Este descobriu que é conveniente manter uma acidez livre baixa, e que a propriedade de proteção da camada formada depende da relação entre a acidez total e a acidez livre, além de notar que o aumento da resistência à corrosão das camadas pode ser obtido acrescendo-se a esta uma película de proteção (cromatos, por exemplo). Observou ainda que alguns agentes podem ser adicionados ao banho com o objetivo de se reduzir o tempo de fosfatização (exemplo: boratos). Este trabalho foi reconhecido como base do processo de fosfatização da maneira que hoje se utiliza [14].

\footnotetext{
${ }^{3}$ W. A. Ross, Improvements in preserving the surface of iron, steel, copper, brass, and other metals or amalgams from being rusted or oxidized by exposure to water or damp air or perspiration, British patent, 1869.

4 1906. Coslett, T. e Coslett Anti Rust Syndicate. Treatment of iron or steel for preventing oxidation or rusting, B. P. Núm. 8.667. 1908. Coslett, T. W. Treatment of iron or steel to prevent oxidation or rusting. B. P. Núm. 15.628. 1909. Coslett, T. W. Treatment of iron or steel to prevent oxidation or rusting. B. P. Núm. 22.743. 1925. Coslett, T. W. e Coslett Anti Rust Syndicate. Treatment of iron or steel to prevent oxidation or rusting, B. P. Núm. 247.071.
} 
O processo de fosfatização sofreu grande evolução, desde então, como a redução dos tempos de processo, de $2 \mathrm{~h}$ a $2,5 \mathrm{~h}$, para $60 \mathrm{~s}$ a $90 \mathrm{~s}$, e a criação do processo por pulverização (spray), o que permitiu a inserção de peças de grandes tamanhos no prétratamento [1].

Outro aspecto observado no decorrer dos anos de pesquisa com fosfatização referese à redução da temperatura do banho, sendo frequentemente observadas hoje temperaturas entre $20^{\circ} \mathrm{C}$ e $35^{\circ} \mathrm{C}$. Porém, este processo ainda apresenta algumas desvantagens, sendo as principais, o uso de metais pesados e de substâncias ácidas e tóxicas nos banhos de fosfatização e no pós-tratamento [1].

Em sequencia aos testes desenvolvidos por Coslett em 1909, quando adicionou zinco aos banhos de fosfato, obtendo uma melhor aderência e cobertura mais uniforme; Richards ${ }^{5}$ propôs em 1911, uma solução à base de manganês, como banho adequado para a produção de camadas de fosfato em ferro e aço [14].

A inclusão de mais de um metal aos banhos data de 1929 quando a Parker Rust Proof Company preparou uma solução à base de fosfato diácido de ferro e manganês, contendo certa quantidade de cobre e agentes oxidantes (principalmente nitratos), sendo comercialmente denominado de Bonderite. Esta tecnologia está atualmente presente no mercado e pertencente à Henkel Corporation. Essa empresa, localizada em Detroit (Michigan/EUA), adquiriu as patentes de W. H. Allen ${ }^{6}$, pesquisador que em seus trabalhos, no período de 1915 a 1918, confirmou a importância da relação entre o ácido fosfórico total e livre. Na sequencia, a Parker Rust Proof Company lançou no mercado o processo denominado "parkerização" [14].

Também na Rússia, de acordo com E. I. Dyrmond, foi produzido um banho a base de fosfato diácido manganês-ferroso, contendo ácido fosfórico livre, sendo denominado comercialmente de Digofat [14].

Outra patente foi obtida em 1924 para o processo denominado de Eletrogranodine, em que o processo de fosfatização foi acelerado pela passagem de corrente alternada (10 a $20 \mathrm{~V}$ e $40 \mathrm{~A} / \mathrm{dm}^{2}$ ). Desde esta data, os processos de fosfatização foram sendo acelerados

\footnotetext{
${ }^{5}$ Richards, J. G. R. Treatment of iron or steel for preventing oxidation. B. P. Número 17.563. 1911.

${ }^{6}$ W. H. Allen. Parker Rust Proof Co. Process for rust proofing iron and steel. U.S.A.P. Núm. 1.206.075 (21VIII-1915) (28-XI-1916). W. H. Allen. Parker Rust Proof Co. Process for rust proofing of metals. U.S.A.P. Núm. 1.215.463 (6-XI-1915; 13-XI-1915) W. H. Allen. Parker Rust Proof Co. Process for rust proofing iron and steel. U.S.A.P. Núm. 1.167.966 (1-I-1916). W. H. Allen. Parker Rust Proof Co. Solution for rust proofing iron and steel. U.S.A.P. Núm. 1.287 .602 (16-VI-1916; 17-XII-1918).
} 
inclusive pela adição de substâncias orgânicas e inorgânicas, muito eficientes e bastante utilizadas nos dias atuais [9].

Em 1928, teve-se registro de um processo denominado Atramentol, onde se utilizou fosfatos diácidos de manganês II e III com ácido fosfórico livre. Este é ainda utilizado hoje como base para oleamento $[9,15]$.

Em 1929, o processo de fosfatização já estava bem difundido e a composição das soluções fosfatizantes consistia basicamente de uma mistura de soluções de ácido fosfórico e sais diácidos diversos com adição de agentes aceleradores como nitrito. Estes processos denominados de bonderização, permitiam a formação da camada de fosfato em substratos metálicos em um intervalo de tempo de 1 a 5 minutos [16].

O uso de camadas fosfatizadas nas operações de conformação é conhecido desde 1934 por Singer. A fosfatização foi muito utilizada na Alemanha, durante a Segunda Guerra Mundial, nas operações de conformação de metais ferrosos, principalmente para a produção de munição [17].

Após a Segunda Guerra Mundial, a fosfatização passou a ter grande importância industrial. No início dos anos 50, surgiram processos mais eficientes para a fosfatização cristalina e a fosfatização de ferro, que vieram a sofrer, nas décadas de 60 e 70, novos desenvolvimentos, impulsionados pela indústria automobilística [16].

Em 1960, a importância da fosfatização para a conformação foi comparável a da resistência à corrosão. Porém, a partir de 1960, a aplicação das camadas fosfatizadas como base de pintura foi superando à da conformação devido ao crescente aumento da indústria automobilística, que utiliza camadas fosfatizadas para melhorar a aderência à tinta [17].

Desde a primeira patente obtida por W. A. Ross (1869), muitas pesquisas foram realizadas sobre fosfatização, buscando-se uma melhoria de desempenho e otimização de processos. Parâmetros como redução do consumo energético, de água e insumos, impulsionaram estas pesquisas, que de fato muito contribuíram para os produtos hoje ofertados no mercado em geral. Grande avanço ocorreu desde as primeiras fosfatizações, sendo atualmente comercializados vários tipos de fosfatos, inorgânicos e orgânicos, aplicáveis sob processos diferentes e disponíveis para variados tipos de aços.

Hoje, no entanto, o principal fator que impulsiona as pesquisas nesta área está relacionado à redução dos problemas ambientais advindos da larga utilização industrial dos banhos de fosfatização. Na lama gerada como resíduo deste processo encontram-se metais 
pesados, classificados como tóxicos e com restrições de descarte. Além do uso, já muito restrito, do cromo hexavalente como passivador da superfície fosfatizada.

As limitações legais, impostas em vários países, relativas à utilização e descarte de elementos nocivos a saúde e ao meio ambiente têm levado muitas empresas e institutos de pesquisa à busca de novas soluções para o processo de fosfatização ou, ainda, a substituição deste por alternativas de tratamento e proteção das superfícies metálicas.

\subsection{Fosfatização}

A fosfatização é um tratamento de conversão normalmente aplicado com o objetivo de proteção contra a corrosão do ferro e aço. A superfície do metal é convertida em um fosfato insolúvel do íon metálico (normalmente $\mathrm{Zn}^{2+}, \mathrm{Fe}^{2+}, \mathrm{Mn}^{2+}$ ) que deposita-se sobre o metal modificando as suas propriedades superficiais [18]. Revestimentos formados por este processo são conhecidos como revestimentos de conversão química. São aderentes, insolúveis, inorgânicos, cristalinos ou amorfos, formados como parte integrante da superfície do metal por meio de uma reação química entre parte do substrato e componentes da solução [19]. A camada resultante é bem mais estável, portanto, menos reativa à corrosão do que a superfície original do substrato, constituindo-se em uma camada protetora. Esses revestimentos também auxiliam na adesão entre os substratos e pinturas ou outros revestimentos orgânicos.

O uso de revestimentos de fosfatos para proteção de superfícies metálicas é conhecido há mais de 50 anos. Neste período, o uso comercial cresceu constantemente. Até hoje, grande parte da produção de motores automotivos, automóveis, bicicletas, refrigeradores, máquinas de lavar, mobiliário de escritório, recebem este tipo de tratamento [20]. Estes revestimentos podem variar de espessura, desde unidades de $\mu \mathrm{m}$ até espessuras superiores a $50 \mu \mathrm{m}$ [21]. São normalmente quantificados em termos de massa por unidade de área, usualmente como g. $\mathrm{m}^{-2}$ [22]. Camadas formadas por fosfato de zinco apresentam valores de massa por área entre 1,0 a 7,0 g.m $\mathrm{m}^{-2}$, e são normalmente utilizadas como base para pinturas. Densidades maiores, entre 7,5 a 60 g.m ${ }^{-2}$ são comumente obtidas para fosfatos de manganês, e normalmente utilizadas para lubrificação e conformação a frio [23, 24].

Revestimentos de fosfato proporcionam uma barreira física efetiva ao processo de corrosão de metais no meio ambiente, apesar de apresentar poros entre os cristais. Devido 
ao isolamento do substrato com o meio, naturalmente propiciado pelo revestimento de fosfato. Estes revestimentos ajudam a prevenir o aparecimento e disseminação da corrosão. Eles apresentam proteção à corrosão tanto em metais ferrosos como em não ferrosos [19].

A fosfatização pode ser aplicada como pré-tratamento de pintura, para auxiliar nas operações de conformação, para aumentar a resistência ao desgaste e à abrasão, para proteção contra corrosão e como tratamento suplementar com óleos e graxas, para melhorar a aderência entre um metal e um não metal (como madeira, plástico, borracha), bem como isolantes elétricos, em elementos de fixação [19, 25, 26].

Fosfatização também é um método amplamente utilizado para reduzir desgaste dos elementos de máquinas e peças em movimento. Fosfatos de manganês são muito usados na indústria automobilística na redução do atrito de um aço contra o outro. Os revestimentos de fosfato não possuem propriedades intrínsecas de lubrificação, mas podem absorver uma quantidade considerável de lubrificantes devido a sua porosidade [19].

A composição dos revestimentos de fosfato é influenciada por um número de fatores como, o método de aplicação (imersão ou aspersão), grau de agitação do banho, tipo e quantidade do acelerador, tipo de substrato e presença de outros íons metálicos [14, $16]$.

\subsubsection{Mecanismo da Fosfatização}

Todas as soluções convencionais de fosfatização são soluções diluídas de ácido fosfórico, contendo um ou mais íons de metais pesados ${ }^{7}$ e/ou metais alcalinos ${ }^{8}$, que apresentam essencialmente ácido fosfórico livre e fosfatos primários dos íons metálicos [19]. Geralmente são usados cátions, como os íons $\mathrm{Zn}^{2+}, \mathrm{Mn}^{2+}$ e $\mathrm{Ni}^{2+}$, e ânions aceleradores, como $\mathrm{NO}_{2}^{-}$e $\mathrm{NO}_{3}^{-}$, acrescidos ao banho [27].

Quando um painel metálico é colocado em uma solução de fosfatização, a reação química inicia-se em regiões microanódicas onde ocorre a dissolução do aço superficial (Reação 1) pela ação do ácido fosfórico livre presente no banho [19]. Nas regiões microcatódicas ocorre a evolução do hidrogênio (Reação 2), reação que consome íons $\mathrm{H}^{+}$

\footnotetext{
${ }^{7}$ Metais pesados, são elementos químicos com densidade acima de 4 ou $5 \mathrm{~g} / \mathrm{cm}^{3}$ (ALLOWAY, B. J. Heavy metal in soils. Glasgow: Chapman \& Hall, 1990. 339p.)

${ }^{8}$ Metais alcalinos são os elementos do Grupo 1 (1A) da Tabela Periódica. Reagem muito facilmente com a água e, quando isso ocorre, formam hidróxidos (bases), liberando oxigênio. In: www.tabela.oxigenio.com/metais_alcalinos/metais_alcalinos.htm.
} 
na superfície do metal, levando a um aumento local de $\mathrm{pH}$ [28]. A Figura 5 ilustra o processo e apresenta estas reações.

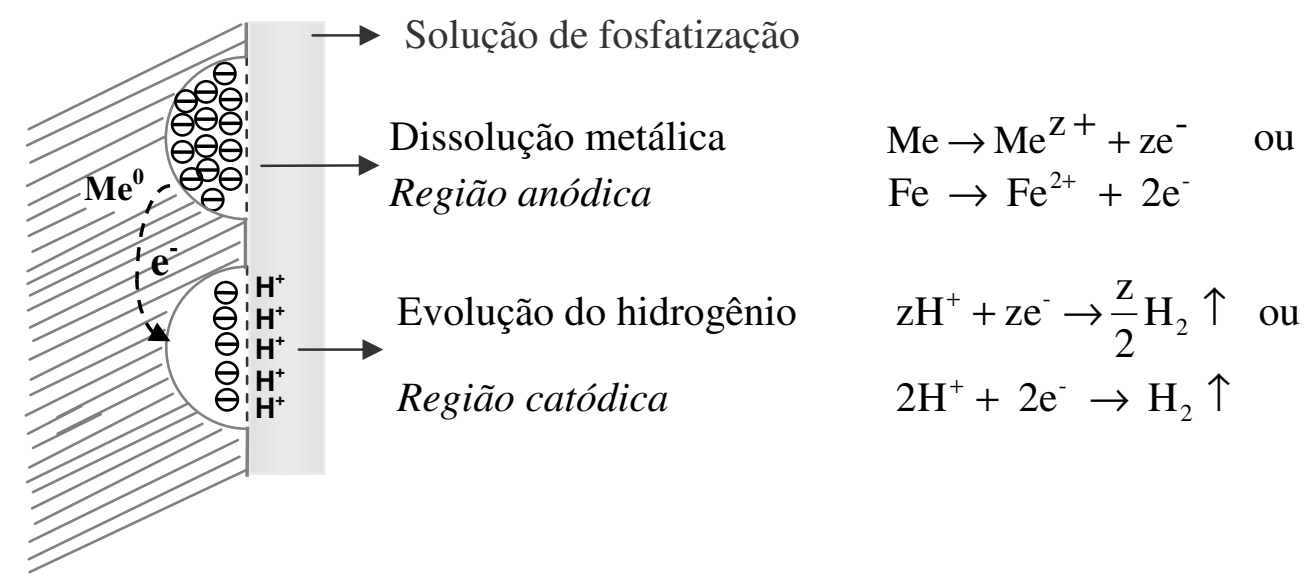

Figura 5. Representação das reações químicas geradas pelo ataque ácido na superfície metálica, de maneira genérica e para superfícies ferrosas.

De maneira mais específica, em superfícies de metais ferrosos, a reação que ocorre na interface metal/solução produz fosfato de ferro solúvel (primário) e libera hidrogênio (Reação 3). A evolução do hidrogênio dificulta a ocorrência de reações com íons dos metais pesados, sendo necessário adicionar aceleradores ao banho [19].

$$
\mathrm{Fe}+2 \mathrm{H}_{3} \mathrm{PO}_{4} \rightarrow \mathrm{Fe}\left(\mathrm{H}_{2} \mathrm{PO}_{4}\right)_{2}+\mathrm{H}_{2} \uparrow
$$

A formação de fosfato de ferro solúvel causa o empobrecimento local da concentração de ácido livre, resultando em aumento do pH na interface metal/solução. Em análises "in situ" com micro-eletrodos, observou-se aumento de $\mathrm{pH}$ de 2,8 para 4,5 próximo à região de crescimento de cristais durante a fosfatização do aço [29].

Esta mudança no $\mathrm{pH}$ altera o equilíbrio existente entre os fosfatos primários solúveis e os fosfatos insolúveis terciários dos metais pesados presentes na solução. Em banhos de fosfatização contendo íons dos metais pesados, tais como $\mathrm{Zn}^{2+}$ e $\mathrm{Mn}^{2+}$, este equilíbrio pode ser representado, de maneira genérica, pelas reações 4 e 5, onde se observa a formação de fosfatos diácidos transformando-se em fosfatos monoácidos (Reação 4), e estes transformando-se em fosfatos neutros (Reação 5). Como o fosfato neutro é insolúvel, precipita-se na superfície do metal formando a camada fosfatizada. Estas reações resultam 
na regeneração do ácido fosfórico na solução. A Figura 6 exemplifica resumidamente, o mecanismo de formação da camada de fosfato de zinco [19, 30].

$$
\begin{gathered}
\mathrm{Me}\left(\mathrm{H}_{2} \mathrm{PO}_{4}\right)_{2} \Leftrightarrow \mathrm{MeHPO}_{4}+\mathrm{H}_{3} \mathrm{PO}_{4} \\
3 \mathrm{MeHPO}_{4} \Leftrightarrow \underset{\text { insolúvel }}{\mathrm{Me}_{3}\left(\mathrm{PO}_{4}\right)_{2}}+\mathrm{H}_{3} \mathrm{PO}_{4}
\end{gathered}
$$

\section{Mecanismo Simplificado da Fosfatização}

Solução de

fosfato de zinco

Zona de conversão

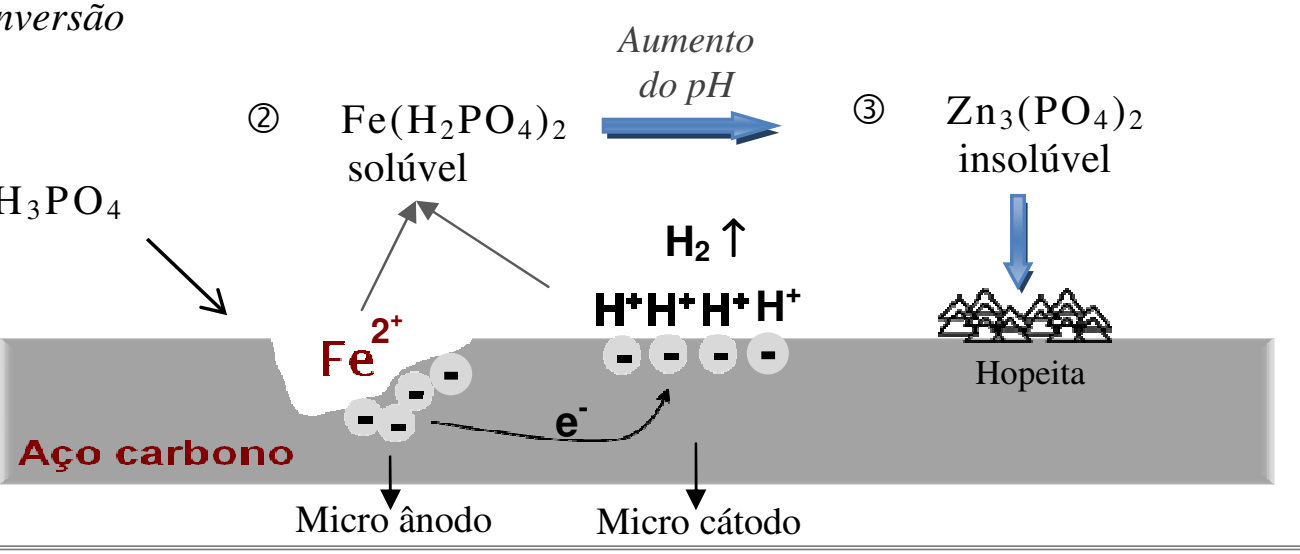

(1) $\mathrm{H}_{3} \mathrm{PO}_{4}$

Figura 6. Mecanismo simplificado de formação da camada de fosfato de zinco sobre aço carbono.

É possível acompanhar os estágios de formação da camada de fosfato através de medidas de potencial em função do tempo de fosfatização. Isto pode ser visto na Figura 7, na qual estão apresentadas as etapas de formação e crescimento da camada cristalina [31]. Na Figura 7 observa-se que o potencial do metal é deslocado para valores mais nobres devido a resistência criada pela precipitação de fosfatos sobre a superfície metálica. Esta variação do potencial ocorre normalmente entre 20 e $150 \mathrm{mV}$, dependendo das condições do tratamento, da superfície metálica e da composição química do banho [31]. 


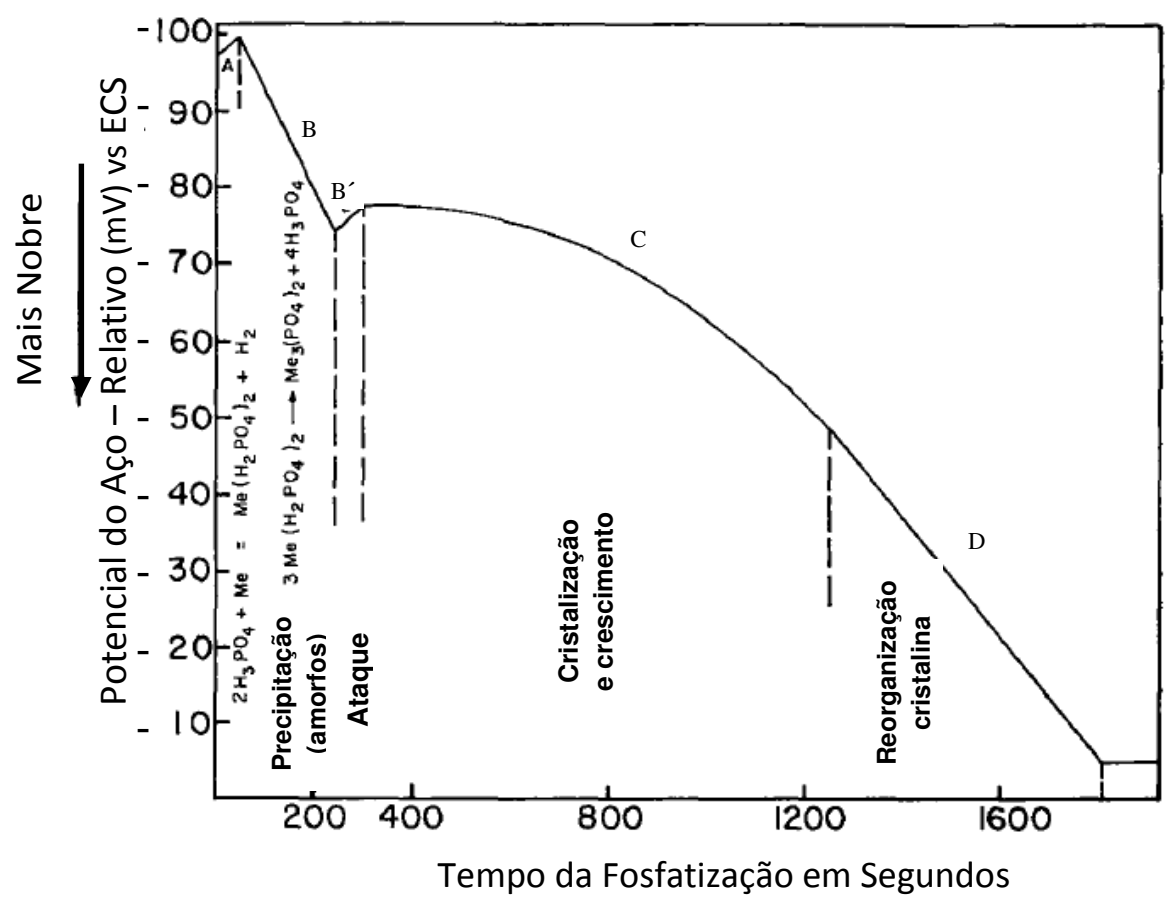

Figura 7. Identificação das etapas da fosfatização relacionadas à valores dos potenciais eletroquímicos medidos durante o processo: A - ataque eletroquímico; B precipitação amorfa; B' - Dissolução do metal base; C - cristalização e crescimento; D - reorganização cristalina [31].

Etapas descritas pela Figura 7 podem ser relacionadas com o mecanismo de fosfatização apresentado na Figura 6. Desta maneira a etapa "A" da Figura 7 identifica o ataque do ácido fosfórico ao ferro representado pelo item (1) da Figura 6. A etapa "BB" da Figura 7 identifica a formação e dissolução do dihidrogeno-fosfato de ferro representado pelo item (2) da Figura 6, e a etapa "C" da Figura 7 identifica a formação e deposição do fosfato insolúvel representado pelo item (3) da Figura 6.

A curva apresentada na Figura 7 foi obtida com amostras polidas eletroliticamente e representa uma média de quinze experimentos. Foram utilizadas amostras de aço carbono, em banho de fosfato de zinco a uma temperatura de $95 \pm 0,5^{\circ} \mathrm{C}$ [31]. A curva mostra principalmente os processos de dissolução do metal, formação do revestimento e finalização deste [31].

As principais fases presentes em revestimentos de fosfato formados sobre substratos de Fe ou Zn são indicadas na Tabela 1 [32]. 
Tabela 1. Principais fases constituintes dos revestimentos de fosfato sobre Fe e Zn [32].

\begin{tabular}{c|c|c}
\hline \multirow{2}{*}{ Metal no banho } & \multicolumn{2}{|c}{ Substrato } \\
\cline { 2 - 3 } & Ferro & Zinco \\
\hline \multirow{2}{*}{$\mathrm{Fe}$} & $\mathrm{Fe}_{3} \mathrm{H}_{2}\left(\mathrm{PO}_{4}\right)_{4} \cdot 4 \mathrm{H}_{2} \mathrm{O}$ (Hureaulita de Fe) & $\mathrm{Zn}_{3}\left(\mathrm{PO}_{4}\right)_{2} \cdot 4 \mathrm{H}_{2} \mathrm{O}$ \\
& $\mathrm{FePO}_{4} \cdot 2 \mathrm{H}_{2} \mathrm{O}$ (Strengita) & $\mathrm{Zn}_{2} \mathrm{Fe}\left(\mathrm{PO}_{4}\right)_{2} \cdot 4 \mathrm{H}_{2} \mathrm{O}$ \\
& $(\mathrm{Mn}, \mathrm{Fe})_{5} \mathrm{H}_{2}\left(\mathrm{PO}_{4}\right)_{4} \cdot 4 \mathrm{H}_{2} \mathrm{O}$ & $\mathrm{Fe}_{5} \mathrm{H}_{2}\left(\mathrm{PO}_{4}\right)_{4} \cdot 4 \mathrm{H}_{2} \mathrm{O}$ \\
\hline \multirow{2}{*}{$\mathrm{Mn}$} & $\mathrm{Zn}_{3}\left(\mathrm{PO}_{4}\right)_{2} \cdot 4 \mathrm{H}_{2} \mathrm{O}$ \\
& $\left.\mathrm{Zn}_{2} \mathrm{Fe}\left(\mathrm{PO}_{4}\right)_{4} \cdot 4 \mathrm{H}_{2}\right)_{2} \mathrm{O}$ (Hureaulita de $\left.\mathrm{Mn}\right)$ & \\
\hline \multirow{2}{*}{$\mathrm{Zn}$} & $\mathrm{Zn}_{3}\left(\mathrm{PO}_{4}\right)_{2} \cdot 4 \mathrm{H}_{2} \mathrm{O}$ (Hosfofilita) & $\mathrm{Zn}_{3}\left(\mathrm{PO}_{4}\right)_{2} \cdot 4 \mathrm{H}_{2} \mathrm{O}$ \\
& & \\
\hline
\end{tabular}

A estrutura das fases fosfofilita e hopeita, principais fases presentes em camadas de fosfato obtidas em banhos contendo Zn sobre substrato de aço, são mostradas nas Figuras 8 e $9[33,34]$.

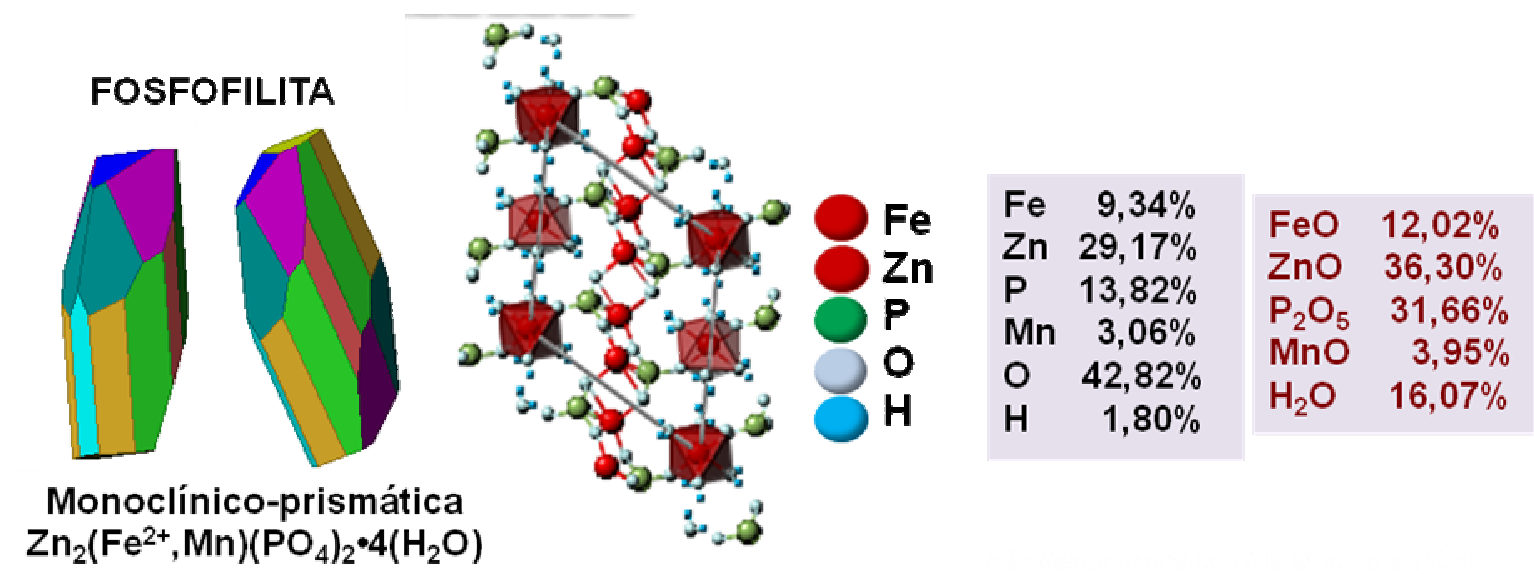

Figura 8. Ilustração e detalhes da estrutura cristalina da fosfofilita [33].
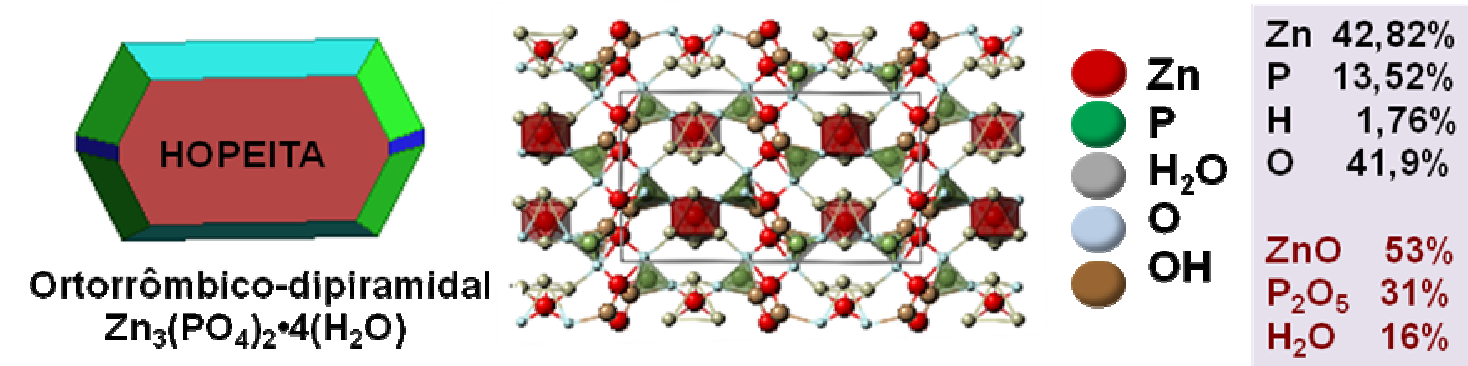

Figura 9. Ilustração e detalhes da estrutura cristalina da hopeita [33]. 
A fosfofilita $\mathrm{Zn}_{2} \mathrm{Fe}\left(\mathrm{PO}_{4}\right)_{2} \cdot 4 \mathrm{H}_{2} \mathrm{O}$ e hopeita $\mathrm{Zn}_{3}\left(\mathrm{PO}_{4}\right)_{2} \cdot 4 \mathrm{H}_{2} \mathrm{O}$ são os essenciais constituintes de revestimentos de fosfato de zinco em substratos ferrosos [19].

Um aumento na relação entre fosfofilita e hopeita leva a um aumento na aderência e resistência à corrosão de camadas de fosfato. Alguns autores [35, 36, 37] têm correlacionado a razão (Equação 6) entre a fosfofilita e hopeita e a resistência à corrosão do revestimento de fosfato. Porém, de acordo com RICHARDSON et al. esta razão não é suficiente para definir a resistência à corrosão do revestimento [37].

$$
\mathrm{P}=\frac{\text { Fosfofilita }}{\text { fosfofilita }+ \text { hopeita }}
$$

Em substratos de aço galvanizado, banhos de fosfato de zinco formam somente a hopeita. Porém a fosfofilita tem sido apresentada como mais resistente do que a hopeita em

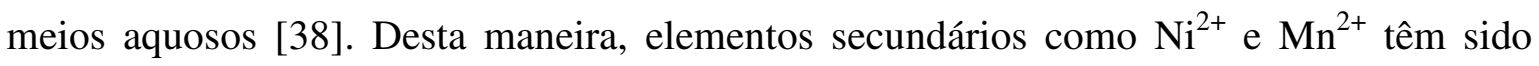
usados para aumento da estabilidade alcalina destas camadas de fosfato de zinco [39].

\subsubsection{Aceleração do Processo de Fosfatização}

As reações responsáveis pela formação das camadas de fosfato podem ser aceleradas quimicamente pela adição de oxidantes ou sais metálicos de metais mais nobres do que o ferro, mecanicamente por agitação ou eletroquimicamente pelo uso de corrente externa [40].

Aceleradores que favoreçam a liberação das bolhas de hidrogênio na superfície podem ser adicionados às soluções de fosfatização. São normalmente utilizados os nitratos $\left(\mathrm{NO}_{3}\right)$, nitritos $\left(\mathrm{NO}_{2}\right)$, cloratos $\left(\mathrm{ClO}_{3}^{-}\right)$, peróxido de hidrogênio $\left(\mathrm{H}_{2} \mathrm{O}_{2}\right)$, hidroxilamina sulfato $\left(\mathrm{NH}_{2} \mathrm{OH}\right)_{2} \cdot \mathrm{H}_{2} \mathrm{SO}_{4}[19,40]$. A Tabela 2 apresenta as vantagens e desvantagens de alguns tipos de aceleradores usados na fosfatização.

A adição de $\mathrm{NO}_{2}^{-}$e $\mathrm{NO}_{3}^{-}$em banhos de fosfatização é uma prática comum que visa a aceleração das reações na superfície, como a taxa de alcalinização local e a subsequente precipitação do fosfato [41]. O nitrito e/ou nitrato apresentam dupla atuação na interface solução/meio; como oxidantes e também despolarizando a superfície do aço, na medida em que consomem o hidrogênio ali formado. 
Embora grande esforço tenha sido empregado para substituir o nitrito por oxidantes menos prejudiciais, atualmente a combinação do nitrito com nitrato é a mais usada [19].

Neste caso, as reações mais importante para aceleração da fosfatização são aquelas indicadas abaixo (Reações 7 e 8) [19]:

$$
\begin{aligned}
& \mathrm{NO}_{3}^{-}+2 \mathrm{H}^{+}+2 \mathrm{e}^{-} \rightarrow \mathrm{NO}_{2}^{-}+\mathrm{H}_{2} \mathrm{O} \\
& \mathrm{NO}_{2}^{-}+2 \mathrm{H}^{+}+\mathrm{e}^{-} \rightarrow \mathrm{NO}+\mathrm{H}_{2} \mathrm{O}
\end{aligned}
$$

\begin{tabular}{|c|c|c|c|c|}
\hline $\begin{array}{l}\text { Tipo do } \\
\text { acelerador }\end{array}$ & Exemplo & $\begin{array}{l}\text { Concentração } \\
\text { efetiva }\end{array}$ & Vantagens & Desvantagens \\
\hline $\mathrm{NO}_{3}^{-}$ & $\begin{array}{l}\mathrm{NaNO}_{3} \\
\mathrm{Zn}\left(\mathrm{NO}_{3}\right)_{2} \\
\mathrm{Ni}\left(\mathrm{NO}_{3}\right)_{2} \\
\end{array}$ & $1-3 \%$ & $\begin{array}{l}\text { Menos lodo da } \\
\text { fosfatização }\end{array}$ & $\begin{array}{l}\text { Redução do } \mathrm{FePO}_{4} \\
\text { aumenta o teor de ferro do } \\
\text { revestimento }\end{array}$ \\
\hline $\mathrm{NO}_{2}^{-}$ & $\mathrm{NaNO}_{2}$ & $0,1-0,2 \mathrm{~g} \cdot \mathrm{L}^{-1}$ & $\begin{array}{l}\text { Permite o } \\
\text { processamento } \\
\text { rápido mesmo em } \\
\text { baixas temperaturas }\end{array}$ & $\begin{array}{l}\text { Vapores corrosivos. } \\
\text { Muito instável em banhos } \\
\text { com alta temperatura. } \\
\text { São necessárias } \\
\text { frequentes adições }\end{array}$ \\
\hline $\mathrm{H}_{2} \mathrm{O}_{2}$ & $\mathrm{H}_{2} \mathrm{O}_{2}$ & $\begin{array}{l}0,05 \text { g.L } \mathrm{L}^{-1} \\
\text { (liquido) }\end{array}$ & $\begin{array}{l}\text { Sem produtos } \\
\text { nocivos. Livre de } \\
\text { manchas }\end{array}$ & $\begin{array}{l}\text { O controle do banho tende } \\
\text { a ser crítico. Formação de } \\
\text { lama pesada. Estabilidade } \\
\text { limitada. Frequentes } \\
\text { adições são necessárias. }\end{array}$ \\
\hline $\mathrm{ClO}_{3}^{-}$ & $\mathrm{Zn}\left(\mathrm{ClO}_{3}\right)_{2}$ & $0,5-1 \%$ & $\begin{array}{l}\text { Estável como } \\
\text { líquido. Pode ser } \\
\text { usado no preparo } \\
\text { dos banhos e na } \\
\text { reposição destes. }\end{array}$ & $\begin{array}{l}\text { Natureza corrosiva do } \\
\text { clorato. Alta concentração } \\
\text { tóxica no banho. Difícil } \\
\text { remoção de precipitados } \\
\text { gelatinosos. }\end{array}$ \\
\hline $\begin{array}{l}\text {-óxido } \\
\text { orgânico }\end{array}$ & $\begin{array}{l}\text { Piridina N-óxido } \\
\text { Morfolina N- } \\
\text { óxido }\end{array}$ & $0,3-2$ g. $\mathrm{L}^{-1}$ & -------- & $\begin{array}{l}\text { Necessita de altas } \\
\text { concentrações para } \\
\text { ativação da solução antes } \\
\text { da fosfatização. }\end{array}$ \\
\hline Hidroxilamina & $\begin{array}{l}\text { Hidroxilamina } \\
\text { Hidroxilamina } \\
\text { sulfato } \\
\end{array}$ & $0,5-5$ g. $\mathrm{L}^{-1}$ & $\begin{array}{l}\text { Cristais esféricos } \\
\text { ou longos. Não se } \\
\text { decompõe sozinho }\end{array}$ & $\begin{array}{l}\text { Decompõe-se na presença } \\
\text { de cobre ou } \mathrm{H}_{2} \mathrm{O}_{2} \text { no } \\
\text { banho }\end{array}$ \\
\hline $\begin{array}{l}\text { Bromato de } \\
\text { metal }+ \\
\text { compostos } \\
\text { aromáticos }\end{array}$ & $\begin{array}{l}\text { Bromato de } \\
\text { sódio + nitro- } \\
\text { composto m- } \\
\text { nitrobenzeno } \\
\text { sulfonato }\end{array}$ & $\begin{array}{l}0,8-1,1+ \\
0,25-0,5 \text { g.L. }\end{array}$ & $\begin{array}{l}\text { Revestimento com } \\
\text { granulação fina. } \\
\text { Melhora a adesão e } \\
\text { resistência à } \\
\text { corrosão. }\end{array}$ & 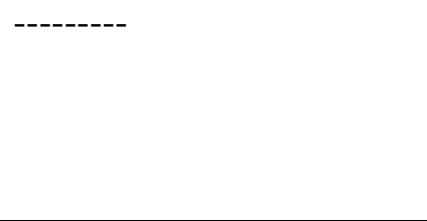 \\
\hline
\end{tabular}

Tabela 2. Diferentes tipos de aceleradores usados em fosfatização [19]. 
A Reação (8) libera óxido nítrico, gás incolor considerado tóxico ao organismo. Presente no ar, oxida-se rapidamente para $\mathrm{NO}_{2}$, que é um gás de cor acastanhada, de cheiro forte, muito tóxico. $\mathrm{NO}_{2}$ é um oxidante altamente reativo e corrosivo. Atua principalmente como um irritante que afeta a mucosa dos olhos, nariz, garganta e trato respiratório e pode diminuir a resistência às infecções respiratórias [42].

O crescimento de cristais de fosfato aumenta a cobertura da superfície do metal cessando quando o processo de corrosão não pode mais manter o gradiente de $\mathrm{pH}$. Com o aumento da concentração do acelerador a mudança de $\mathrm{pH}$ na superfície do metal torna-se maior e resulta em uma maior densidade de nucleação e de crescimento mais rápido dos cristais de fosfato [19].

\subsubsection{Tipos e Propriedade dos Fosfatos}

Os principais banhos de fosfatização são de fosfato de ferro, de zinco e de manganês, e a combinação destes. Atualmente, a fosfatização é aplicada, principalmente, sobre metais ferrosos (aço, aço zincado e ferro fundido), alumínio e suas ligas, zinco e suas ligas, e cádmio e suas ligas [18]. As Tabelas 3 e 4 exemplificam a relação entre soluções fosfatizantes, o tipo de substrato tratado, finalidade dos recobrimentos e sistemas de aplicação [14].

Existem também soluções fosfatizantes à base de produtos orgânicos, geralmente soluções de monoésteres ou diésteres alifáticos e ésteres aromáticos de ácido fosfórico. Estas, porém resultam em camadas que apresentam resultados inferiores no que se refere à resistência a corrosão [14].

A proteção proporcionada pelos fosfatos à superfície do metal depende da espessura do revestimento utilizado e da massa depositada por área recoberta, podendo ser maior para valores maiores de espessura e densidade, ainda que a morfologia da camada cristalina e porosidade existente apresentem grande influência.

Aumento significativo da proteção à corrosão pode ser alcançado pela aplicação final de tintas e óleos. Os revestimentos de fosfato oferecem uma ótima base para aplicação de pinturas, sendo este seu principal uso [35]. Eles podem ser usados como 
excelente base para tintas aplicadas pelos métodos mais modernos de pintura, tais como a pintura eletroforética ${ }^{9}$ e a aplicação de tinta a pó ${ }^{10}$ [19].

Tabela 3. Soluções de Fosfatização para substratos de ferro e aço carbono [14].

\begin{tabular}{|c|c|c|c|}
\hline $\begin{array}{l}\text { Metal a } \\
\text { Tratar }\end{array}$ & $\begin{array}{c}\text { Banho de } \\
\text { Fosfatização }\end{array}$ & Objetivo do Tratamento & $\begin{array}{l}\text { Procedimento } \\
\text { de Aplicação }\end{array}$ \\
\hline \multirow{7}{*}{$\begin{array}{c}\text { Superfícies } \\
\text { de Ferro e } \\
\text { aço }\end{array}$} & \multirow{3}{*}{$\begin{array}{l}\text { Fosfato de } \\
\quad \text { zinco }\end{array}$} & $\begin{array}{l}\text { Obtenção de base aderente para as } \\
\text { pinturas }\end{array}$ & $\begin{array}{c}\text { Imersão ou } \\
\text { pulverização }\end{array}$ \\
\hline & & $\begin{array}{l}\text { Prevenção da corrosão e retenção de } \\
\text { óleos }\end{array}$ & Imersão \\
\hline & & $\begin{array}{l}\text { Melhora das condições de obtenção de } \\
\text { peças por conformação mecânica }\end{array}$ & Imersão \\
\hline & \multirow{3}{*}{$\begin{array}{l}\text { Fosfato de } \\
\quad \text { ferro }\end{array}$} & $\begin{array}{l}\text { Obtenção de base aderente para as } \\
\text { pinturas }\end{array}$ & \multirow{3}{*}{ Imersão } \\
\hline & & $\begin{array}{l}\text { Prevenção da corrosão e retenção de } \\
\text { óleos }\end{array}$ & \\
\hline & & $\begin{array}{l}\text { Melhora das condições de obtenção de } \\
\text { peças por conformação mecânica }\end{array}$ & \\
\hline & $\begin{array}{l}\text { Fosfato de } \\
\text { manganês }\end{array}$ & Resistência ao Desgaste & Imersão \\
\hline
\end{tabular}

Tabela 4. Soluções de Fosfatização para substratos não ferrosos [14].

\begin{tabular}{c|c|lc|c}
\hline $\begin{array}{c}\text { Metal a } \\
\text { Tratar }\end{array}$ & $\begin{array}{c}\text { Banho de } \\
\text { Fosfatização }\end{array}$ & \multicolumn{1}{|c|}{ Objetivo do Tratamento } & $\begin{array}{c}\text { Procedimento } \\
\text { de Aplicação }\end{array}$ \\
\hline \multirow{2}{*}{$\begin{array}{c}\text { Superfícies } \\
\text { de Zinco }\end{array}$} & $\begin{array}{c}\text { Fosfato de } \\
\text { zinco }\end{array}$ & $\begin{array}{l}\text { Obtenção de base aderente para } \\
\text { pinturas }\end{array}$ & $\begin{array}{c}\text { Imersão ou } \\
\text { pulverização }\end{array}$ \\
\cline { 2 - 5 } & Fosfato de ferro & $\begin{array}{l}\text { Obtenção de base aderente para } \\
\text { pinturas }\end{array}$ & Imersão \\
\hline $\begin{array}{c}\text { Superfícies } \\
\text { de Cádmio }\end{array}$ & $\begin{array}{c}\text { Fosfato de } \\
\text { zinco }\end{array}$ & $\begin{array}{l}\text { Obtenção de base aderente para } \\
\text { pinturas }\end{array}$ & Imersão \\
\hline $\begin{array}{c}\text { Superfícies } \\
\text { de Alumínio }\end{array}$ & $\begin{array}{c}\text { Fosfato de } \\
\text { zinco }\end{array}$ & $\begin{array}{l}\text { Obtenção de base aderente para } \\
\text { pinturas }\end{array}$ & Imersão \\
\hline
\end{tabular}

\footnotetext{
${ }^{9}$ Pintura por processo de imersão em que a tinta tem formulação especial que permite sua polarização. Uma diferença de potencial é estabelecida entre a tinta e a peça metálica, de modo que a tinta seja atraída pelo metal [9].

${ }^{10}$ É uma tinta na forma de pó seco, sendo a película formada pela fusão do pó. Pode ser realizado com pistola eletrostática, ocorrendo a formação de um campo magnético quando da saída do pó, que deixa as partículas carregadas negativamente, sendo estas atraídas pelo metal aterrado [9].
} 
Soluções de fosfato de zinco e manganês podem ser modificadas pela adição de sais de níquel. A adição deste íon metálico causa o refinamento de grão e melhora de maneira significativa a resistência à corrosão das camadas fosfatizadas. Banhos deste tipo, especialmente desenvolvidos e conhecidos como banhos tricatiônicos, podem ser utilizados para fosfatizar alumínio, aço e aço zincado [43].

A adição de sais de níquel em uma solução de fosfatos é uma prática corrente na fosfatização. O níquel se deposita na chapa de aço ou de zinco [44], sob a forma de partículas microscópicas, o que resulta no aumento do número de centros ativos que dão origem aos cristais de fosfato [45]. O níquel é depositado na superfície como níquel metálico, por cementação [46]. A adição de níquel nos banhos de fosfatização também tem o efeito de aumentar a resistência à corrosão, bem como a aderência das camadas do revestimento [44]. A Tabela 5 apresenta os tipos de fosfatos mais utilizados.

Tabela 5. Tipos e propriedades dos fosfatos mais utilizados [47].

\begin{tabular}{l|l|l|l}
\hline Tipo de fosfato & Processo & Coloração & Propriedades \\
\hline Fosfato de ferro & Pulverização & $\begin{array}{l}\text { Cinza claro ou } \\
\text { cinza escuro }\end{array}$ & Melhor aderência à tintas \\
\hline Fosfato de zinco & $\begin{array}{l}\text { Imersão ou } \\
\text { pulverização }\end{array}$ & Azulada & $\begin{array}{l}\text { Melhor resistência } \\
\text { anticorrosiva }\end{array}$ \\
\hline $\begin{array}{l}\text { Fosfato de zinco, } \\
\text { níquel e } \\
\text { manganês }\end{array}$ & Imersão & $\begin{array}{l}\text { Cinza escuro à } \\
\text { marrom escuro }\end{array}$ & $\begin{array}{l}\text { São chamados de fosfatos } \\
\text { tricatiônicos com } \\
\text { excelente resistência } \\
\text { anticorrosiva e aderência à } \\
\text { tinta. São fosfatos de } \\
\text { última geração. }\end{array}$ \\
\hline
\end{tabular}

Tradicionalmente, o fosfato de zinco era aplicado sobre aço carbono, resultando em camadas de fosfatos com elevada resistência à corrosão, devido à presença de duas fases, a hopeita (fosfato de zinco) e fosfofilita (fosfato de ferro e zinco).

Já a camada de fosfato de zinco sobre aço zincado apresenta somente a hopeita [48]. Quando o aço zincado passou a ser muito usado, particularmente na indústria automobilística, tornou-se necessária a adição de outros elementos como manganês e níquel ao banho de fosfato de zinco, com o objetivo de aumentar sua estabilidade alcalina. Banhos denominados de tricatiônicos, compostos por zinco, manganês e níquel, surgiram devido à necessidade de melhoria da resistência à corrosão de revestimentos de fosfato de zinco sobre aço zincado (galvanizado). 
Segundo OGLE, 2004 [49], o $\mathrm{Mn}^{2+}$ e o $\mathrm{Ni}^{2+}$ substituem o $\mathrm{Zn}^{2+}$ formando a pseudofosfofilita (Fórmula Química 9), levando a uma amorfização ${ }^{11}$ da camada de fosfato de zinco.

$$
\mathrm{Zn}_{(3-\mathrm{x}-\mathrm{y}-\mathrm{z})} \mathrm{Fe}_{\mathrm{x}} \mathrm{Mn}{ }_{\mathrm{y}} \mathrm{Ni}_{\mathrm{z}}\left(\mathrm{PO}_{4}\right)_{2} \cdot 4 \mathrm{H}_{2} \mathrm{O}
$$

OGLE et al. [49] comprovaram a eficácia da adição de níquel e manganês aos banhos de fosfato de zinco, para aumentar a resistência ao ataque alcalino de aços zincados, e boa concordância entre amostras de aço fosfatizadas em banho de fosfato de zinco e amostras de aço zincado fosfatizadas em banhos tricatiônicos, sendo este resultado principalmente atribuído à adição do manganês ao banho.

A resistência da camada de fosfato em meio alcalino representa uma importante propriedade das camadas de conversão, particularmente no que se refere à adesão da pintura com o metal, e é comumente aceito que a composição da camada de fosfato tem uma forte influência na estabilidade química desta interface [49].

\subsubsection{Processo de Fosfatização}

A fosfatização industrial de metais pode ser executada por aspersão ou pelo processo de imersão [50]. Este último é o método usual de aplicação de revestimentos de fosfato. Neste processo, uma sequencia de tanques que incluem estágios de desengraxe e fosfatização, com seus respectivos enxágues, é utilizada. O tempo de tratamento varia entre 3 e 5 minutos para revestimentos de fosfato de zinco, e entre 30 e 60 minutos, para revestimentos espessos de fosfato de zinco, ferro ou manganês [18].

A sequencia mais completa de um tratamento de fosfatização consiste basicamente dos seguintes estágios [51]: preparação da superfície por limpeza mecânica, desengraxamento e/ou decapagem, condicionamento ou refinamento de grão, fosfatização, selagem ou passivação.

\footnotetext{
${ }^{11}$ Redução da característica cristalina do revestimento.
} 


\section{Limpeza mecânica, desengraxamento e/ou decapagem:}

A limpeza por processo mecânico, desengraxe e/ou decapagem consiste em retirar da superfície a ser fosfatizada quaisquer resíduos que possam interferir na qualidade da camada fosfatizada. Uma superfície limpa, livre de graxas, óleos e óxidos, é essencial para a obtenção de uma camada de fosfato de boa qualidade. Oleosidades e outras sujidades podem ser removidas com o uso de solventes, solventes emulsionáveis, desengraxantes alcalinos, jateamento com areia ou granalha, preparando, assim, as superfícies para a fosfatização. Desengraxantes alcalinos ou alcalinos fortes, em concentrações de $1 \%$ a $5 \%$ e pH entre 10 e 13, são os mais utilizados [26, 52].

\section{Condicionamento ou refinamento do cristal:}

O objetivo deste tratamento é promover o refinamento de grão, sendo aplicado antes do estágio de fosfatização. Promove a nucleação da camada de fosfato de zinco ou de manganês, com cristais finos e homogêneos, sendo ideal para o acabamento por pintura. São normalmente soluções de fosfato de titânio e sódio utilizadas como condicionadores. Para o fosfato de manganês, é comum o uso de uma solução de fosfato complexo de manganês [52].

Esta etapa do processo, que antecede a fosfatização, cria pontos de nucleação na superfície metálica, os quais induzem a formação de cristais pequenos e fortemente aderidos. O tamanho dos cristais é importante para desempenho da fosfatização. A boa eficiência do refinador, que é constituído de sais de titânio, depende de uma boa operação prévia de desengraxe e decapagem. O refinador, por ser um banho levemente alcalino, funciona também como uma decapagem alcalina com banho bem controlado. Este, além de remover os óxidos leves e as oleosidades, condiciona a superfície, pois um $\mathrm{pH}$ residual alto, promove a precipitação dos fosfatos, formando cristais pequenos [47].

\section{Fosfatização:}

É o estágio de formação da camada de fosfato. Existe uma série de fatores que influenciam notadamente as propriedades do revestimento de fosfato [14], como: composição e características físicas do substrato, preparação da superfície, composição da solução fosfatizante, temperatura de trabalho e tempo de imersão. 


\section{Pós-tratamento de selagem ou passivação:}

A selagem ou passivação da peça fosfatizada ocorre por imersão desta em solução aquosa com algum composto inorgânico, dentre os quais: compostos de cromo hexavalente ou trivalente, silicatos, fosfatos, boratos, nitritos, molibdatos e cloreto estanoso [53]. Segundo FERNÁNDEZ (1962) [14], a passivação causa a diminuição da porosidade do revestimento, e, consequentemente, aumenta sua resistência à corrosão. Pesquisa realizada pelo laboratório americano Rock Island Arsenal chegou à conclusão de que o melhor tratamento para passivação consiste em um enxágue com uma solução aquosa de cromo hexavalente $\left(\mathrm{CrO}_{3}\right)[14]$.

Entre os diferentes estágios é feita lavagem com água, com o objetivo de retirar da superfície do metal resíduos da solução anterior e evitar a contaminação da solução subsequente. É importante ressaltar que a passagem de um estágio para outro deve ser feita rapidamente, de modo a evitar a secagem da superfície em processo de fosfatização [51]. A Figura 10 apresenta um processo usual de fosfatização por imersão.

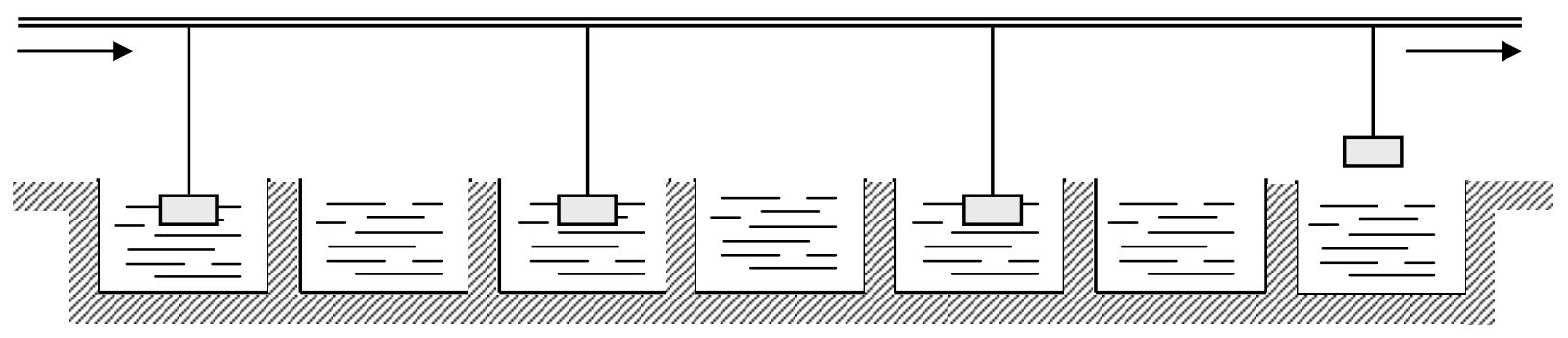

Desengraxe Enxágue Refinamento Fosfatização Enxágue Passivação Enxágue

Figura 10. Sequencia usual automatizada de fosfatização por imersão.

\subsection{Aspectos Ambientais Ligados a Fosfatização}

O processo de fosfatização é composto por várias etapas, em que as peças metálicas vão sendo gradativamente imergidas em banhos ou aspergidas por estes. As soluções que compõem estes banhos apresentam $\mathrm{pH}$ variado, desde muito ácido $(\mathrm{pH} \cong 3)$, a muito básico $(\mathrm{pH} \cong 13)$. Contêm metais e outros componentes que tornam o resíduo deste processo tóxico e de difícil descarte. O lodo ou lama de fosfatização (LF), como é denominado, é classificado como "Resíduo Classe I - Perigoso", segundo a norma brasileira NBR 10004:2004, devido à toxicidade decorrente da presença do cromo e níquel [54]. Em 
alguns casos o LF é depositado em aterro de resíduos industriais próprios (ARIP) ou encaminhado para co-processamento em fornos de cimento.

Pesquisas têm sido desenvolvidas buscando-se um aproveitamento deste resíduo, visto ser significativo o volume gerado, como mostra a Tabela 6 [55]. Um levantamento realizado pela Fundação Estadual do Meio Ambiente (FEAM) de Minas Gerais apresentou, em 2003, dados quantitativos da geração de borra de fosfato através do Inventário Estadual de Resíduos Sólidos Industriais, estabelecida através da Resolução CONAMA nº 313, de 29 de outubro de 2002 [55].

Tabela 6. Resíduos nos quais pode estar contida a borra de fosfato [55].

\begin{tabular}{|c|c|c|c|}
\hline $\begin{array}{l}\text { Ramo } \\
\text { Industrial }\end{array}$ & Tipo de Resíduo & $\begin{array}{l}\text { Geração } \\
\text { (t/ano) }\end{array}$ & Destino \\
\hline \multirow[t]{2}{*}{$\begin{array}{l}\text { Fabricação de } \\
\text { máquinas e } \\
\text { equipamentos }\end{array}$} & $\begin{array}{l}\text { Resíduos e lodo de tinta da pintura } \\
\text { industrial. }\end{array}$ & 65,60 & $\begin{array}{l}\text { Sem destino definido, co- } \\
\text { processamento em fornos de } \\
\text { cimento e sucateiros } \\
\text { intermediários. }\end{array}$ \\
\hline & $\begin{array}{l}\text { Lodos de sistema de tratamento de } \\
\text { águas residuárias da pintura industrial. }\end{array}$ & 27,10 & Sem destino definido. \\
\hline \multirow{2}{*}{$\begin{array}{l}\text { Fabricação de } \\
\text { máquinas, } \\
\text { aparelhos e } \\
\text { materiais } \\
\text { elétricos }\end{array}$} & $\begin{array}{l}\text { Resíduos e lodos de tinta da pintura } \\
\text { industrial. }\end{array}$ & 0,99 & $\begin{array}{l}\text { Sem destino definido, co- } \\
\text { processamento em fornos de } \\
\text { cimento. }\end{array}$ \\
\hline & $\begin{array}{l}\text { Lodos de sistema de tratamento de } \\
\text { águas residuárias da pintura industrial. }\end{array}$ & 37,30 & $\begin{array}{l}\text { Co-processamento em fornos } \\
\text { de cimento. }\end{array}$ \\
\hline \multirow{2}{*}{$\begin{array}{l}\text { Fabricação de } \\
\text { produtos } \\
\text { químicos }\end{array}$} & $\begin{array}{l}\text { Resíduos e lodos de tinta da pintura } \\
\text { industrial. }\end{array}$ & 34,20 & $\begin{array}{l}\text { Co-processamento em fornos } \\
\text { de cimento. }\end{array}$ \\
\hline & $\begin{array}{l}\text { Lodos de sistema de tratamento de } \\
\text { águas residuárias da pintura industrial. }\end{array}$ & 43,90 & $\begin{array}{l}\text { Co-processamento em fornos } \\
\text { de cimento. }\end{array}$ \\
\hline \multirow{2}{*}{$\begin{array}{l}\text { Fabricação de } \\
\text { produtos de } \\
\text { metal (exclusive } \\
\text { máquinas e } \\
\text { equipamentos) }\end{array}$} & $\begin{array}{l}\text { Resíduos e lodos de tinta da pintura } \\
\text { industrial. }\end{array}$ & 182,50 & $\begin{array}{l}\text { Sem destino definido, aterro } \\
\text { sanitário municipal, } \\
\text { sucateiros intermediários }\end{array}$ \\
\hline & $\begin{array}{l}\text { Lodos de sistema de tratamento de } \\
\text { águas residuárias da pintura industrial. }\end{array}$ & - & - \\
\hline \multirow{2}{*}{$\begin{array}{l}\text { Fabricação e } \\
\text { montagem de } \\
\text { veículos } \\
\text { automotores, } \\
\text { reboques e } \\
\text { carrocerias }\end{array}$} & $\begin{array}{l}\text { Resíduos e lodos de tinta da pintura } \\
\text { industrial. }\end{array}$ & 289,44 & $\begin{array}{l}\text { Sem destino definido e co- } \\
\text { processamento em fornos de } \\
\text { cimento }\end{array}$ \\
\hline & $\begin{array}{l}\text { Lodos de sistema de tratamento de } \\
\text { águas residuárias da pintura industrial. }\end{array}$ & $2.436,50$ & $\begin{array}{l}\text { Sem destino definido, co- } \\
\text { processamento em fornos de } \\
\text { cimento e aterro industrial de } \\
\text { terceiros }\end{array}$ \\
\hline \multirow[t]{2}{*}{$\begin{array}{l}\text { Metalurgia } \\
\text { básica }\end{array}$} & $\begin{array}{l}\text { Resíduos e lodos de tinta da pintura } \\
\text { industrial. }\end{array}$ & 20 & Incineração \\
\hline & $\begin{array}{l}\text { Lodos de sistema de tratamento de } \\
\text { águas residuárias da pintura industrial. }\end{array}$ & $\longrightarrow$ & - \\
\hline & Total & \multicolumn{2}{|c|}{$3.137,53$ t/ano } \\
\hline
\end{tabular}


No processo de fosfatização em etapas, além da geração de resíduo, o alto consumo de água e o tratamento dos efluentes também representam aspectos ambientais negativos, o que fortalece a necessidade de pesquisa nesta área e o interesse industrial em novas opções.

Algumas pesquisas estão voltadas ao aproveitamento da lama de fosfatização, por exemplo, como alternativa para fabricação de tijolos, ou no preparo de mudas de espécies nativas utilizadas em reflorestamento e recuperação de áreas degradadas [55, 56].

Os problemas ambientais decorrentes do processo de fosfatização superam a disposição final de seu resíduo, pois incluem também o preparo e aplicação do produto. A Tabela 7 apresenta os possíveis impactos ambientais causados pela etapa de fosfatização e pinturas industriais, muito usados na indústria automobilística [57].

Tabela 7. Impactos Ambientais e suas fontes na etapa de fosfatização [57].

\begin{tabular}{l|l}
\hline Impacto Ambiental & Fonte do impacto \\
\hline Poluição do ar e odores & Névoas \\
\hline Rejeitos na água & $\begin{array}{l}\text { Mudança do banho: metais, pH. } \\
\text { Limpeza dos tanques }\end{array}$ \\
\hline \multirow{2}{*}{ Consumo de água } & $\begin{array}{l}\text { Substituição dos banhos } \\
\text { Compensação da evaporação } \\
\text { Lavagem dos tanques }\end{array}$ \\
\hline Poluição dos solos & Fugas nos tanques ou na canalização, acidente \\
\hline Rejeitos industriais especiais & $\begin{array}{l}\text { Borra da fosfatização } \\
\text { Ácido nítrico (limpeza do tanque) }\end{array}$ \\
\hline Energia (recursos naturais) & $\begin{array}{l}\text { Manutenção do banho à } 50{ }^{\circ} \mathrm{C} . \\
\text { Filtro pressurizado. }\end{array}$ \\
\hline
\end{tabular}

Grandes usuárias do passivador à base de cromo hexavalente, as indústrias automotivas foram levadas a rever seu uso após publicação da Diretiva Européia 2000/53/CE, relativa a veículos em fim de vida útil. Esta norma ressalta a importância da aplicação de medidas preventivas a partir da fase de projeto dos veículos, com o objetivo de reduzir e controlar as substâncias perigosas, e evitar a sua liberação para o meio ambiente, facilitar a sua reciclagem e evitar a necessidade de eliminação de resíduos perigosos. Neste contexto, esta regulamentação determinou a proibição do chumbo, mercúrio, cádmio e/ou do cromo hexavalente, sendo estes somente permitidos em atividades específicas determinadas por uma listagem em constante revisão [58]. 
A Diretiva Européia 2000/53/CE determinou que, nos revestimentos anticorrosivos aplicados em diversas partes dos automóveis comercializados a partir de $1^{\mathrm{o}}$. de julho de 2003, não deveria conter mais que dois gramas do cromo hexavalente por veículo. Apesar de parecer uma grande restrição, os resíduos gerados por automóveis em fim de vida, na comunidade europeia, chegam a oito ou nove milhões de toneladas por ano [58].

Devido a estes problemas, a prevenção da poluição vem sendo tema de discussões entre os fornecedores de fosfato para a indústria automobilística. Muitos projetos já foram criados para a prevenção da contaminação ambiental [59]. A troca do níquel e do cromo por composto de nióbio vem ao encontro desta importante necessidade ambiental, que é a redução de compostos cancerígenos em processos industriais.

\subsection{Nióbio}

\subsubsection{Características e Obtenção}

O nióbio $(\mathrm{Nb})$ ou colômbio $(\mathrm{Cb})$ é um elemento metálico de número atômico 41 na tabela periódica. Sua massa específica é de $8,57 \mathrm{~g} / \mathrm{cm}^{3}$, superior à do ferro, e seu ponto de fusão é de $2.468^{\circ} \mathrm{C}$. À temperatura ambiente resiste bem à ação de ácidos clorídrico (até 35\%), sulfúrico (até 95\%), nítrico concentrado, fosfórico, crômico, acético, fórmico e cítrico [60].

O elemento 41 foi descoberto na Inglaterra, em 1801, por Charles Hatchett, que na época o denominou de colúmbio. Posteriormente, o químico alemão Heinrich Rose, pensando haver encontrado um novo elemento ao separá-lo do metal tântalo, deu-lhe o nome de nióbio em homenagem a Níobe, filha do mitológico rei Tântalo [61].

A ocorrência de nióbio na natureza está associada aos pegmatitos, sob a forma de colombita-tantalita, ou associada à carbonatitos de maciços alcalinos, constituindo-se o mineral denominado pirocloro [60].

Até a descoberta quase simultânea de depósitos de pirocloro no Canadá (Oka) e no Brasil (Araxá), na década de 1950, o uso do nióbio era limitado pela oferta limitada (era um subproduto do tântalo) e custo elevado. Com a produção primária de nióbio, o metal tornou-se abundante e ganhou importância no desenvolvimento de materiais de engenharia [60]. 


\subsubsection{Aplicação}

No início da década de 1930, o nióbio passou a ser utilizado na prevenção de corrosão intergranular em aços inoxidáveis [61]. Os avanços conseguidos até aqui ampliaram o raio de aplicação do nióbio em aços, superligas, materiais intermetálicos e ligas de $\mathrm{Nb}$, bem como em compostos, revestimentos, nanomateriais, dispositivos optoeletrônicos e catalisadores [60].

A aplicação mais importante do nióbio é como elemento de liga para conferir melhoria de propriedades em produtos de aço, especialmente nos aços de alta resistência e baixa liga, usados na fabricação de automóveis e de tubulações para transmissão de gás sob alta pressão. Outra aplicação importante é seu emprego em superligas que operam a altas temperaturas em turbinas das aeronaves a jato. O nióbio é também adicionado ao aço inoxidável utilizado em sistema de escapamento dos automóveis, e ainda na produção de ligas supercondutoras de nióbio-titânio usadas na fabricação de magnetos para tomógrafos de ressonância magnética. Encontra aplicação também em cerâmicas eletrônicas e em lentes para câmeras [60].

\subsubsection{Disponibilidade}

As reservas nacionais medidas de nióbio $\left(\mathrm{Nb}_{2} \mathrm{O}_{5}\right)$ aprovadas pelo Departamento Nacional de Produção Mineral (DNPM) totalizam 212.487.575 t de minério, com teor médio de 2,02\%, ou 4.302.248 t de nióbio contido. Elas estão concentradas nos Estados de Minas Gerais (73,11\%), Amazonas (25,42\%) e Goiás (1,47\%) [60].

O Brasil mantém a liderança na oferta de nióbio no cenário mundial, atingindo uma participação de $92,4 \%$ da produção mundial de $\mathrm{Nb}_{2} \mathrm{O}_{5}$ contido no minério, que totalizou 33.998 t, em 2000 [60].

A jazida de Araxá constitui a maior reserva mundial de nióbio. É explorada pela Companhia Brasileira de Mineração e Metalurgia (CBMM). O óxido de nióbio, que representa $13 \%$ do mercado mundial da substância, contém $99 \%$ de $\mathrm{Nb}_{2} \mathrm{O}_{5}$ e é a matériaprima utilizada para obtenção de produtos de terceira geração: níquel-nióbio, ferro-nióbio de alta pureza, óxidos especiais de nióbio (grau ótico e grau cristal) e nióbio metálico.

As reservas de nióbio são suficientes para sustentar os níveis projetados de demanda por mais de dois séculos. A tendência de mercado é de estabilização, pois os 
recursos minerais são extremamente abundantes e os atuais níveis de capacidade produtiva, tanto para o ferronióbio como para o óxido, são suficientes ao atendimento dos níveis esperados de demanda mundial dos próximos dez anos [60].

A proposta de inclusão do nióbio no processo de fosfatização apresenta-se também como economicamente viável, devido à grande oferta do produto de origem nacional.

\subsection{Oxalato de Nióbio e Amônio}

Embora existam muitos avanços em pesquisas com óxidos multi-metálicos contendo nióbio, pesquisas na área de revestimentos de materiais têm sido dificultadas pela falta apropriada de fontes específicas de nióbio. O desenvolvimento de novas fontes representa uma grande mudança neste contexto, sendo observado recentemente que muitos esforços têm ocorrido na obtenção de novos precursores de nióbio que possam apresentar propriedades versáteis, tais como, solubilidade e estabilidade [62].

A produção do oxalato de nióbio e amônio vem atender a esta demanda por precursores de $\mathrm{Nb}$ com propriedades de solubilidade. A Companhia Brasileira de Metalurgia e Mineração (CBMM) detém patente para obtenção deste composto [63]. O oxalato amoniacal de nióbio (ou oxalato de nióbio e amônio) obtido pelo processo de produção da CBMM apresenta-se como um sólido branco, de estrutura cristalina monoclínica, com teor de nióbio na faixa de 5\% a 30\% em peso, solúvel em água, cuja solubilidade apresenta-se na faixa de 60 a 160 gramas de nióbio por litro de água, em temperaturas de $20{ }^{\circ} \mathrm{C}$ a $80{ }^{\circ} \mathrm{C}$, conforme apresentado na Figura 11. Este composto pode ser usado como precursor de nióbio para síntese de materiais, tais como cerâmicas, catalisadores e filmes finos em que o nióbio é o constituinte principal [63]. 


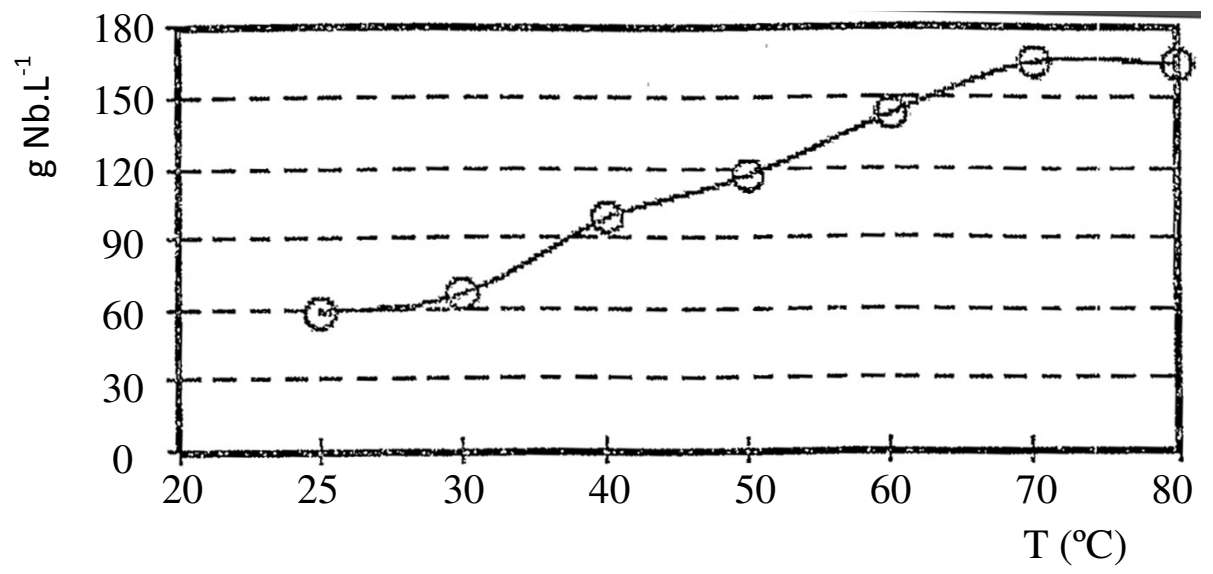

Figura 11. Solubilidade do oxalato amoniacal de nióbio em função da temperatura $[63]$.

Além do oxalato de nióbio e amônio, outros precursores de $\mathrm{Nb}$ podem ser encontrados no mercado como fonte comercial de $\mathrm{Nb}(\mathrm{V})$ (Tabela 8) [62].

Tabela 8. Algumas fontes comerciais disponíveis para $\mathrm{Nb}(\mathrm{V})$ [62].

\begin{tabular}{|c|c|c|}
\hline Nome comum & Formulação & Aspecto \\
\hline Pentóxido de nióbio & $\mathrm{Nb}_{2} \mathrm{O}_{5}$ & Pó cristalino branco \\
\hline $\begin{array}{l}\text { Ácido nióbico ou óxido de } \\
\text { nióbio hidratado }\end{array}$ & $\mathrm{Nb}_{2} \mathrm{O}_{5} \cdot \mathrm{nH}_{2} \mathrm{O}$ & Pó amorfo branco \\
\hline Pentacloreto de nióbio & $\mathrm{NbCl}_{5}$ & Pó cristalino amarelo \\
\hline $\begin{array}{l}\text { Sal oxalato de nióbio e } \\
\text { amônio }\end{array}$ & $\mathrm{NH}_{4} \mathrm{H}_{2}\left[\mathrm{NbO}\left(\mathrm{C}_{2} \mathrm{O}_{4}\right)_{3}\right] \cdot 3 \mathrm{H}_{2} \mathrm{O}$ & Pó cristalino branco \\
\hline
\end{tabular}

O pentóxido de nióbio é um composto muito insolúvel e pouco reativo. O ácido nióbico apresenta-se como o material mais conveniente como precursor do $\mathrm{Nb}(\mathrm{V})$ para sínteses envolvendo soluções aquosas. Porém este composto é bastante instável e perde reatividade com o tempo. O pentacloreto de nióbio e outros pentaóxidos são as fontes mais usadas de nióbio. Quando usado o $\mathrm{NbCl}_{5}$ é possível que o material final seja contaminado pelo cloreto. O oxalato de nióbio e amônio, também denominado de "complexo solúvel de oxalato de nióbio", é geralmente descrito como $\mathrm{NH}_{4} \mathrm{H}_{2}\left[\mathrm{NbO}\left(\mathrm{C}_{2} \mathrm{O}_{4}\right)_{3}\right] \cdot 3 \mathrm{H}_{2} \mathrm{O}$ (Figura 12). Com este complexo, apesar de solúvel em água, a solução resultante não é estável ao longo do tempo em relação à hidrólise, sendo sua estabilização alcançada pela adição do ácido oxálico. Este composto ainda é pouco estudado e caracterizado [62]. 


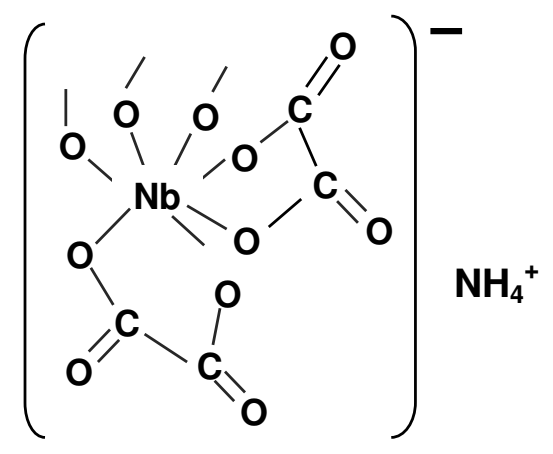

Figura 12. Estrutura molecular básica do ânion oxalato de nióbio em que o átomo de nióbio é coordenado por 7 átomos de oxigênio e 2 grupos oxalatos [63].

\subsection{Passivação de Camadas Fosfatizadas}

Passivação é um fenômeno de bloqueio dos processos de corrosão que ocorre como consequência de mudanças na superfície dos metais [64], e depende do material e do meio no qual está inserido. Alguns metais e ligas, como níquel, cromo, molibdênio, titânio, zircônio, aços inoxidáveis, se passivam ao ar. Outros somente sofrem passivação em meios muito específicos [9].

FERNÁNDEZ (1962) apresenta a resistência à corrosão pela fosfatização das peças metálicas, após teste de névoa salina, para os fosfatos de ferro, zinco e manganês (Tabela 9). Nesta tabela evidencia-se a importância do tratamento de passivação após fosfatização, levando a mais que o dobro da resistência a corrosão, em horas [14].

Tabela 9. Resistência à corrosão dos principais tipos de revestimentos de fosfatos ${ }^{12}$ [14].

\begin{tabular}{c|c|c|c}
\hline \multirow{2}{*}{$\begin{array}{c}\text { Processo de } \\
\text { Acabamento }\end{array}$} & \multicolumn{3}{|c}{ Número de Horas de Exposição à Névoa Salina } \\
\cline { 2 - 4 } & Fosfato de Ferro & Fosfato de Zinco & Fosfato de Manganês \\
\hline Oleado & $160 / 200$ & $140 / 190$ & $160 / 200$ \\
\hline $\begin{array}{c}\text { Oleado e } \\
\text { pintado }\end{array}$ & $400 / 450$ & $350 / 400$ & $450 / 500$ \\
\hline $\begin{array}{c}\text { Passivado, } \\
\text { oleado e pintado }\end{array}$ & $1000 / 1400$ & $1000 / 1300$ & $1000 / 1500$ \\
\hline
\end{tabular}

\footnotetext{
${ }^{12}$ Estes testes foram realizados pela empresa: Walterisation Co. Ltd., e cedido ao autor para publicação.
} 
A quantidade de horas apresentadas nesta tabela não se refere ao início da corrosão, mas ao momento em que o número de manchas de óxido chega a $2 / \mathrm{cm}^{2}$. Estes testes foram realizados segundo a norma ASTM D610/41 [65].

\subsubsection{Cromo Hexavalente}

Apesar da resistência proporcionada pela fosfatização ao aço, a corrosão pode iniciar-se pelos poros ainda existentes, onde o aço permanece exposto. A passivação desses poros representa uma proteção adicional a estas camadas, devido a formação de um filme superficial que atua impedindo o acesso de agentes agressivos ao substrato.

Enxágue a quente $\left(70\right.$ a $\left.80{ }^{\circ} \mathrm{C}\right)$ em solução diluída de cromo hexavalente é geralmente usado para este propósito, resultando na redução da porosidade das camadas fosfatizadas em torno de 50\%, devido a deposição de cromatos insolúveis nas áreas descobertas do revestimento [66]. A concentração usualmente adotada varia entre $0,0125 \%$ a $0,050 \%$. Excesso de cromo provoca bolhas, má aderência e amarelamento da pintura [67]. São preferidas as soluções com pH entre 2 e 5 [19].

Análises por XPS de superfícies fosfatizadas tratadas com cromato sugerem que o revestimento consiste principalmente de óxido de cromo trivalente $\left(\mathrm{Cr}_{2} \mathrm{O}_{3}\right)$ e uma pequena quantidade de compostos de cromo hexavalente, como $\mathrm{Cr}(\mathrm{OH})_{3} \cdot 1,5 \mathrm{H}_{2} \mathrm{O}$ [68].

A formação da película ocorre por reação química entre a superfície do metal (depositado), ativadores, catalisadores e cromo trivalente e hexavalente. O processo químico é uma reação de oxi-redução, onde o metal é oxidado a sua valência normal (+2 ou +3) e o cromo hexavalente é reduzido ao estado trivalente [69].

Processos adequados por passivação crômica originam películas uniformes, de cor amarela, azul, castanha ou verde oliva, dependendo da espessura e do substrato [70].

Apesar do desenvolvimento de tratamentos alternativos, ainda existe uma forte credibilidade de que o grau de proteção contra corrosão fornecida por estes não é tão boa quanto à obtida em tratamentos com cromo hexavalente [19]. 


\subsubsection{Nióbio}

O nióbio tem sido usado como aditivo em aços e ligas para aumento da resistência à corrosão [71]. Foi observado em trabalho anterior, efeitos relativos à passivação de camadas fosfatizadas de zinco e níquel por composto de nióbio [2].

A formação de um filme superficial de óxido que se forma espontaneamente ao ar ou em presença de umidade é o responsável pela grande resistência à corrosão do $\mathrm{Nb}$ metálico em diversos meios, incluindo aqueles altamente corrosivos. Este filme passivo apresenta característica bastante protetora e fortemente aderente [72].

A Figura 13 mostra o diagrama de Pourbaix a $25^{\circ} \mathrm{C}$ para o sistema $\mathrm{Nb}-\mathrm{H}_{2} \mathrm{O}$ [73]. Este diagrama representa as condições de estabilidade termodinâmica do $\mathrm{Nb}$ e seus derivados que possam existir na presença de água e soluções aquosas livres de substâncias capazes de formarem complexos solúveis ou compostos insolúveis com o $\mathrm{Nb}$ [72].

É possível observar no diagrama que em toda faixa de $\mathrm{pH}$ há tendência do metal a se passivar (domínio de estabilidade do $\mathrm{Nb}_{2} \mathrm{O}_{5}$ ), tanto em meios redutores quanto em oxidantes [72].

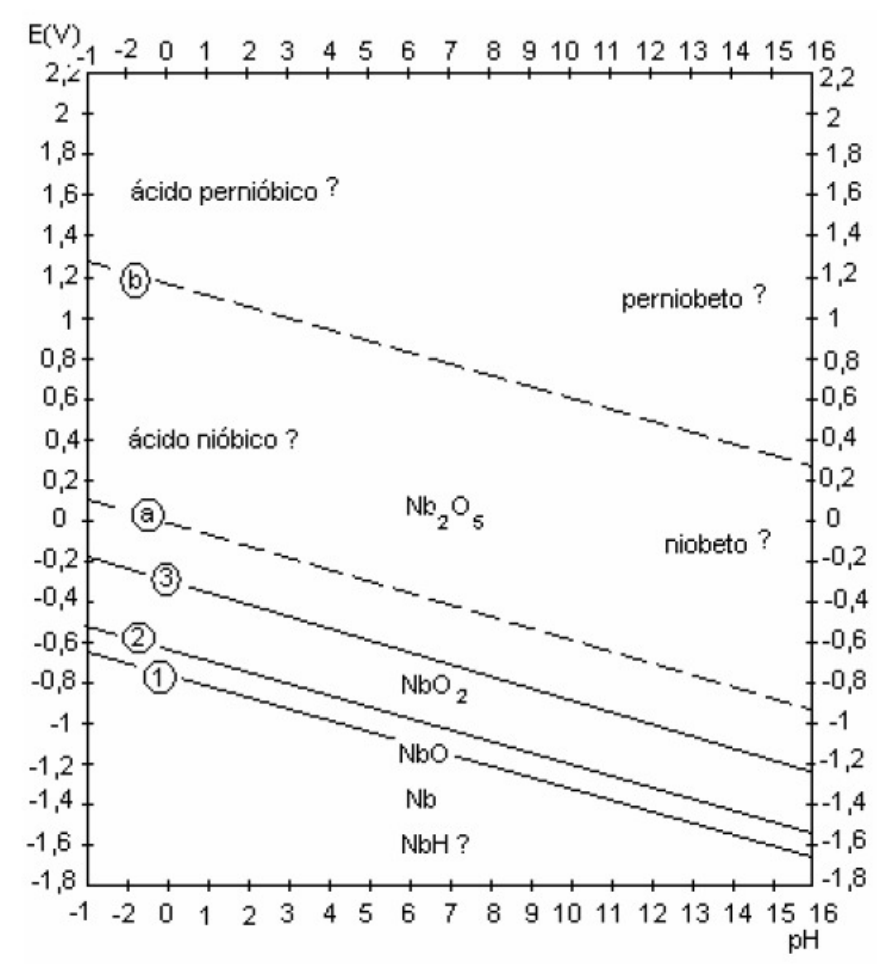

Figura 13. Diagrama de equilíbrio potencial-pH para o sistema $\mathrm{Nb}-\mathrm{H}_{2} \mathrm{O}$, a $25^{\circ} \mathrm{C}$ [73]. 
Verifica-se a formação dos óxidos $\mathrm{NbO}, \mathrm{NbO}_{2}$ e $\mathrm{Nb}_{2} \mathrm{O}_{5}$ de acordo com as seguintes reações [74]:

$$
\begin{aligned}
& \mathrm{Nb}+\mathrm{H}_{2} \mathrm{O} \rightarrow \mathrm{NbO}+2 \mathrm{H}^{+}+2 \mathrm{e}^{-} \\
& \mathrm{NbO}+\mathrm{H}_{2} \mathrm{O} \rightarrow \mathrm{NbO}_{2}+2 \mathrm{H}^{+}+2 \mathrm{e}^{-} \\
& 2 \mathrm{NbO}_{2}+\mathrm{H}_{2} \mathrm{O} \rightarrow \mathrm{Nb}_{2} \mathrm{O}_{5}+2 \mathrm{H}^{+}+2 \mathrm{e}^{-}
\end{aligned}
$$

Os óxidos $\mathrm{NbO}$ e o $\mathrm{NbO}_{2}$ são instáveis em água e em soluções aquosas, já o $\mathrm{Nb}_{2} \mathrm{O}_{5}$ apresenta estabilidade termodinâmica em presença de água, ácidos não complexantes, soluções neutras e alcalinas, podendo ser atacado por ácido fluorídrico concentrado formando complexos fluorados ou oxifluorados [72]. 


\section{PROGRAMA EXPERIMENTAL}

\subsection{Descrição Geral}

Esta pesquisa foi dividida em duas fases diferenciadas pelos tipos de concentrados de fosfato tricatiônico usados na elaboração dos banhos. Na primeira fase foi utilizada uma solução concentrada de fosfato tricatiônico elaborada em laboratório, e na segunda, utilizou-se um concentrado industrial.

Para facilitar o entendimento e identificação dos banhos e camadas de fosfatos obtidos com estes diferentes concentrados, foi criada uma denominação para cada, conforme apresentado na Tabela 10:

Tabela 10. Denominação dos banhos e camadas de fosfato utilizados neste trabalho.

\begin{tabular}{l|l}
\hline Descrição do Concentrado de Fosfato & $\begin{array}{l}\text { Banhos e Camadas de } \\
\text { Fosfato }\end{array}$ \\
\hline Concentrado Laboratorial - Fosfato tricatiônico composto por & Ftric Zn,Mn,Ni \\
zinco, níquel e manganês, cuja formulação foi elaborada em & Ftric Zn,Mn+Nb \\
laboratório através de composição baseada em fosfato de zinco & Fbic Zn,Mn \\
cedida por uma indústria de eletrodomésticos ${ }^{13}$. & \\
\hline Concentrado Industrial - Fosfato tricatiônico composto por Zn, & ST617 Zn,Mn,Ni \\
Mn e Ni e bicatiônico, (Zn, Mn) cedidos por uma indústria & ST617 Zn,Mn+Nb \\
química na Grande São Paulo ${ }^{14}$. A partir do bicatiônico (Zn e & \\
Mn) e com base na composição do tricatiônico industrial, foi & \\
montado o banho tricatiônico com Nb. & \\
\hline
\end{tabular}

Com base no banho padrão de Ftric Zn,Mn,Ni foram elaborados banhos tricatiônicos sem o níquel em sua composição, onde foram acrescidas concentrações variadas de nióbio. Após as fosfatizações nesses banhos a morfologia das camadas obtidas foram avaliadas por microscopia eletrônica de varredura (MEV). As condições de

\footnotetext{
${ }^{13}$ Atlas Indústria de Eletrodomésticos Ltda. Rodovia BR 158, Km 508 - Bairro Petrycosky. Pato Branco / Paraná.

${ }^{14}$ A sigla ST617 faz referência ao concentrado comercializado e cedido pela SurTec do Brasil Ltda., denominado de $\operatorname{SurTec}^{\circledR}$ 617, para fosfatização tricatiônica.
} 
padronização e de aplicação do banho tricatiônico com níquel foram mantidas para o banho sem níquel contendo, em seu lugar, o composto de nióbio (Ftric $\mathrm{Zn}, \mathrm{Mn}+\mathrm{Nb}$ ).

Questões relacionadas à influência do composto de nióbio no banho tricatiônico sem níquel foram investigadas através de testes realizados com o fosfato contendo somente zinco e manganês (Fbic Zn,Mn).

Para escolha do tempo de imersão do substrato nos banhos de fosfato, foram realizados testes para determinação do tempo de estabilização das camadas. Esta determinação foi realizada por ensaio gravimétrico para o banho padrão (Ftric Zn,Mn,Ni), e adotada também para o banho composto por zinco, manganês e nióbio, e para o composto com zinco e manganês.

Foram realizados, em seguida, testes eletroquímicos e de caracterização destas camadas de fosfato, detalhados ainda neste capítulo. Os resultados obtidos com a inclusão do composto de nióbio no banho foram promissores e parcerias com indústrias em São Paulo levaram a uma nova fase da pesquisa, sendo utilizadas, a partir desta segunda fase, soluções concentradas fornecidas por uma indústria química localizada na Grande São Paulo, utilizada para fosfatização tricatiônica em peças e partes de veículos automotores.

Amostras do concentrado para preparo do banho tricatiônico padrão (ST617 $\mathrm{Zn}, \mathrm{Mn}, \mathrm{Ni}$ ) e de outro concentrado sem a adição do níquel, para inclusão do composto de nióbio (ST617 Zn,Mn) foram doadas por esta indústria química.

Foram realizadas novas caracterizações e análises eletroquímicas dessas amostras fosfatizadas com base no concentrado industrial ST617, obtendo-se também resultados promissores em relação à substituição do níquel pelo composto de nióbio. O fluxograma da Figura 14 mostra, de forma simplificada, a sequencia inicialmente adotada nesta pesquisa. 


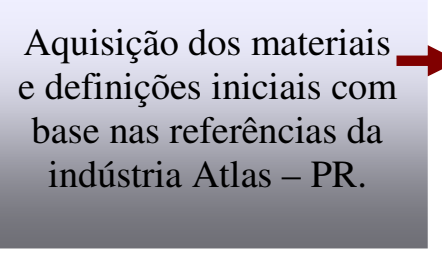

Apoio à esta pesquisa por indústrias em São Paulo.
Definição das melhores condições para aplicação do fosfato tricatiônico com nióbio.

Recebimento de amostras do concentrado de fosfato tricatiônico industrial (ST617).
Testes de caracterização e eletroquímicos das camadas de Ftric $\mathrm{Zn}, \mathrm{Mn}+\mathrm{Nb}$. Os resultados foram promissores.
Novos testes eletroquímicos e de caracterização das camadas fosfatizadas com base nos produtos industrializados.

Figura 14. Fluxograma do desenvolvimento da pesquisa.

A melhor concentração de nióbio no banho de fosfato acrescido ao zinco e manganês foi definida pela morfologia das camadas fosfatizadas. Foi selecionada a melhor cobertura superficial indicada por micrografias obtidas por $\mathrm{MEV}^{15}$.

Várias condições de fosfatização para a composição com o nióbio foram testadas variando-se a temperatura do banho, tempo de imersão da placa no banho e concentração do acelerador. Duas condições foram selecionadas atendendo o critério de melhor cobertura do substrato (item 6.1). A avaliação entre as condições selecionadas foi realizada por comparação dos resultados dos ensaios eletroquímicos em meio de cloreto de sódio.

Para o estudo do efeito da passivação sobre camadas fosfatizadas, foi adotado como padrão, soluções com base no cromo hexavalente ${ }^{16}$, e como alternativa para substituição do cromo hexavalente, soluções contendo composto de nióbio. Foi necessário investigar as condições de maior efetividade do composto de nióbio como passivador sobre o aço carbono fosfatizado. Para tanto, foram realizados testes eletroquímicos preliminares nos quais foi variado o pH da solução e a concentração de nióbio. Após seleção das melhores condições, amostras de aço foram fosfatizadas, algumas sendo passivadas com $\mathrm{CrO}_{3} \mathrm{e}$ outras com composto de nióbio, em seguida, o comportamento eletroquímico destas foi avaliado em meio de cloreto.

A avaliação do desempenho frente à corrosão das camadas fosfatizadas e passivadas, foi realizada considerando-se os resultados dos ensaios eletroquímicos, bem como dos testes de corrosão acelerada, por exposição das placas em câmaras de névoa salina. $\mathrm{O}$

\footnotetext{
${ }^{15}$ Foi definida como condição de melhor cobertura superficial, a camada de fosfato que em micrografias apresentasse o substrato metálico completamente recoberto.

${ }^{16}$ Concentrado também fornecido pela indústria química, SurTec do Brasil Ltda. Denominado de Dream $\mathrm{N}^{\mathrm{o}}$. 401 A, elaborado sob encomenda por não ser mais comercializado.
} 
fluxograma da Figura 15 apresenta como foi desenvolvida a parte final da pesquisa com os novos banhos desenvolvidos com base em banho industrial fornecido por indústria química nacional.

Recebimento de amostra do passivador a base de $\mathrm{CrO}_{3}$. Investigação do composto de nióbio como passivador da superfície fosfatizada
Testes eletroquímicos comparativos entre camadas fosfatizadas e passivadas com cromo e composto de nióbio.
Testes finais em câmaras de névoa salina, com amostras fosfatizadas, passivadas e revestidas com tinta.

Figura 15. Fluxograma das etapas finais da pesquisa.

\subsection{Materiais}

\subsubsection{Substrato Metálico}

Foi utilizado como substrato metálico, aço carbono classificado como $\mathrm{SAE}^{17} 1005$. A composição deste aço está apresentada na Tabela 11. O Anexo A mostra os laudos das análises.

Tabela 11. Caracterização química de amostras de aço carbono.

\begin{tabular}{c|c}
\hline \multicolumn{2}{c}{ Aço 1005 } \\
\hline \multirow{2}{*}{ Elemento } & Composição do aço (\% massa) \\
\hline $\mathrm{C}$ & $0,048 \pm 0,005$ \\
\hline $\mathrm{Si}$ & $0,010 \pm 0,001$ \\
\hline $\mathrm{Mn}$ & $0,239 \pm 0,003$ \\
\hline $\mathrm{P}$ & $0,026 \pm 0,001$ \\
\hline $\mathrm{S}$ & $0,006 \pm 0,001$ \\
\hline $\mathrm{Cr}$ & $0,067 \pm 0,001$ \\
\hline $\mathrm{Ni}$ & $0,016 \pm 0,001$ \\
\hline $\mathrm{Mo}$ & $0,007 \pm 0,001$ \\
\hline
\end{tabular}

${ }^{17}$ AISI-SAE Standard Carbon Steel Composition. 
Foram utilizadas amostras de aço com formato retangular e em tamanhos distintos, de acordo com o teste adotado, a saber: para ensaios de caracterização, área igual a 300 $\mathrm{mm}^{2}(15 \mathrm{~mm}$ x $20 \mathrm{~mm})$; para ensaios eletroquímicos, área igual a $600 \mathrm{~mm}^{2}$ (20 mm x 30 $\mathrm{mm})$ e, para ensaios de corrosão acelerada, área igual a $11.250 \mathrm{~mm}^{2}(75 \mathrm{~mm}$ x $150 \mathrm{~mm})$.

Todas as amostras foram lixadas sequencialmente com lixas de carbeto de silício (SiC), nas granulometrias de \#320, \#400, \#600, lavadas com água deionizada e então fosfatizadas.

\subsubsection{Reagentes Químicos}

Vários compostos químicos foram utilizados nas diversas etapas do trabalho. A Tabela 12 relaciona os reagentes com as atividades nas quais foram usados, apresentando sua finalidade. $\mathrm{O}$ detalhamento das atividades descritas na Tabela 12 está apresentado no item 5.4 "Métodos Experimentais".

A presença do nióbio nos banhos de fosfatização e de passivação se deu através da inclusão do oxalato de nióbio e amônio, cedido pela Companhia Brasileira de Metalurgia e Mineração (CBMM), localizada em Araxá - Minas Gerais. 
Tabela 12. Compostos químicos utilizados na pesquisa.

\begin{tabular}{|c|c|c|}
\hline Composto químico & Finalidade da inclusão & Atividade \\
\hline $\begin{array}{l}\text { Ácido fosfórico } 85 \% \\
\left(\mathrm{H}_{3} \mathrm{PO}_{4}\right)\end{array}$ & $\begin{array}{l}\text { Formação dos produtos - fosfatos } \\
\text { metálicos }\end{array}$ & \multirow{8}{*}{$\begin{array}{c}\text { Elaboração das soluções } \\
\text { concentradas e dos } \\
\text { banhos de fosfatização }\end{array}$} \\
\hline $\begin{array}{l}\text { Ácido nítrico } 65 \% \\
\left(\mathrm{HNO}_{3}\right)\end{array}$ & $\begin{array}{l}\text { Oxidante, na transformação do } \mathrm{Fe}^{+2} \\
\text { para } \mathrm{Fe}^{+3}[9]\end{array}$ & \\
\hline $\begin{array}{l}\text { Carbonato de manganês } \\
\left(\mathrm{MnCO}_{3}\right)\end{array}$ & $\begin{array}{l}\text { Inclusão do manganês à solução de } \\
\text { fosfato }\end{array}$ & \\
\hline $\begin{array}{l}\text { Carbonato de níquel } \\
\left(\mathrm{NiCO}_{3}\right)\end{array}$ & Inclusão do níquel à solução de fosfato & \\
\hline $\begin{array}{l}\text { Oxalato de nióbio e amônio } \\
\left(\mathrm{NH}_{4} \mathrm{H}_{2}\left[\mathrm{NbO}\left(\mathrm{C}_{2} \mathrm{O}_{4}\right)_{3}\right] \cdot 3 \mathrm{H}_{2} \mathrm{O}\right)\end{array}$ & Inclusão do nióbio à solução de fosfato & \\
\hline Óxido de zinco $(\mathrm{ZnO})$ & Inclusão do zinco à solução de fosfato & \\
\hline $\begin{array}{l}\text { Peróxido de hidrogênio } \\
\left(\mathrm{H}_{2} \mathrm{O}_{2}\right)\end{array}$ & Acelerador para fosfatização & \\
\hline $\begin{array}{l}\text { Hidróxido de sódio } \\
(\mathrm{NaOH})\end{array}$ & $\begin{array}{l}\text { Acerto prévio da acidez nos banhos de } \\
\text { fosfatização }\end{array}$ & \\
\hline $\begin{array}{l}\text { Azul de bromofenol } \\
\left(\mathrm{C}_{19} \mathrm{H}_{10} \mathrm{Br}_{4} \mathrm{O}_{5} \mathrm{~S}\right)\end{array}$ & Indicador químico & \multirow{3}{*}{$\begin{array}{l}\text { Padronização dos } \\
\text { banhos de fosfatização }\end{array}$} \\
\hline $\begin{array}{l}\text { Fenolftaleína } \\
\left(\mathrm{C}_{2} \mathrm{OH}_{14} \mathrm{O}_{4}\right)\end{array}$ & Indicador químico & \\
\hline Hidróxido de sódio & Titulação & \\
\hline $\begin{array}{l}\text { Nitrito de sódio } \\
\left(\mathrm{NaNO}_{2}\right)\end{array}$ & $\begin{array}{l}\text { Acelerador acrescido ao banho de } \\
\text { fosfato padronizado }\end{array}$ & \multirow{3}{*}{ Processo de fosfatização } \\
\hline $\begin{array}{l}\text { Cromo hexavalente } \\
\left(\mathrm{CrO}_{3}\right)\end{array}$ & Passivador das camadas fosfatizadas & \\
\hline Oxalato de nióbio e amônio & Passivador das camadas fosfatizadas & \\
\hline Cromo hexavalente $(5 \%)$ & Remoção das camadas de fosfato & Ensaio gravimétrico \\
\hline $\begin{array}{l}\text { Cloreto de sódio } \\
(\mathrm{NaCl})\end{array}$ & $\begin{array}{l}\text { Usado como eletrólito e para } \\
\text { vaporização nas câmaras de névoa } \\
\text { salina }\end{array}$ & $\begin{array}{l}\text { Ensaios eletroquímicos } \\
\text { e de corrosão acelerada }\end{array}$ \\
\hline $\begin{array}{l}\text { Fosfato de potássio } \\
\text { monobásico } \\
\left(\mathrm{KH}_{2} \mathrm{PO}_{4}\right)\end{array}$ & Elaboração de soluções tamponadas & \multirow{4}{*}{$\begin{array}{l}\text { Investigação da } \\
\text { passivação pelo } \\
\text { composto de nióbio nos } \\
\text { ensaios eletroquímicos }\end{array}$} \\
\hline $\begin{array}{l}\text { Fosfato de sódio dibásico } \\
\left(\mathrm{Na}_{2} \mathrm{HPO}_{4}\right)\end{array}$ & Elaboração de soluções tamponadas & \\
\hline Hidróxido de sódio & Elaboração de soluções tamponadas & \\
\hline Oxalato de nióbio e amônio & $\begin{array}{l}\text { Adicionado para verificação da } \\
\text { passivação }\end{array}$ & \\
\hline
\end{tabular}




\subsection{Equipamentos}

\subsubsection{Dispositivo para Controle da Temperatura nos Banhos}

O processo de fosfatização para as amostras com área de $300 \mathrm{~mm}^{2}$ e $600 \mathrm{~mm}^{2}$ foi realizado em béqueres com capacidade superior ou igual a $500 \mathrm{~mL}$. Um dispositivo montado em laboratório $^{18}$, e ilustrado na Figura 16, permitiu o controle e manutenção da temperatura nos banhos de desengraxe, refinamento e de fosfatização. O aquecimento se deu através de fios resistores e de uma manta de $\operatorname{Kevlar}^{19}$, sendo controlado através de um termostato.

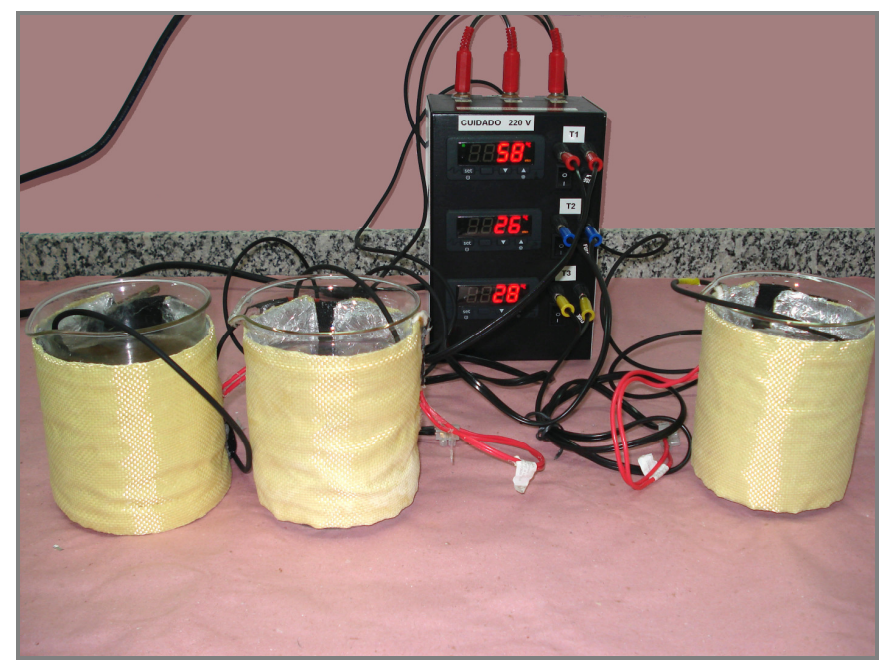

Figura 16. Dispositivo para controle de temperatura nos banhos de fosfatização.

\subsubsection{Linha Piloto de Fosfatização}

Para fosfatização das amostras com área igual a $11.250 \mathrm{~mm}^{2}$, foi utilizada uma linha de fosfatização industrial desenvolvida através de parceria com a BASS Equipamentos Ltda. ${ }^{20}$ (Figura 17). A linha de fosfatização, conforme detalhes apresentados

\footnotetext{
${ }^{18}$ Elaborado pelo aluno Luiz Rossi.

${ }^{19}$ Fibra sintética de aramida muito resistente e leve. Trata-se de um polímero resistente ao calor e mais resistente que o aço por unidade de massa.

http://www2.dupont.com/Kevlar/en_US/assets/downloads/KEVLAR_Technical_Guide.pdf

${ }^{20}$ BASS Equipamentos Ltda., endereço: Rua Lapa, 326 Barueri/SP.
} 
nas Figuras 18 e 19, foi fabricada em resina com fibra de vidro, constando de sete cubas com volume individual aproximado de 14 litros. Na Figura 17, o sistema de controle da temperatura é observado no painel frontal, sendo que a transferência de calor às soluções ocorre através de resistores em aço inox situados no interior das cubas.

Foi previsto aquecimento para quatro cubas, especificamente as que continham as soluções desengraxante, refinadora, de fosfatização e passivadora. O Anexo B apresenta o projeto da linha de fosfatização completo.

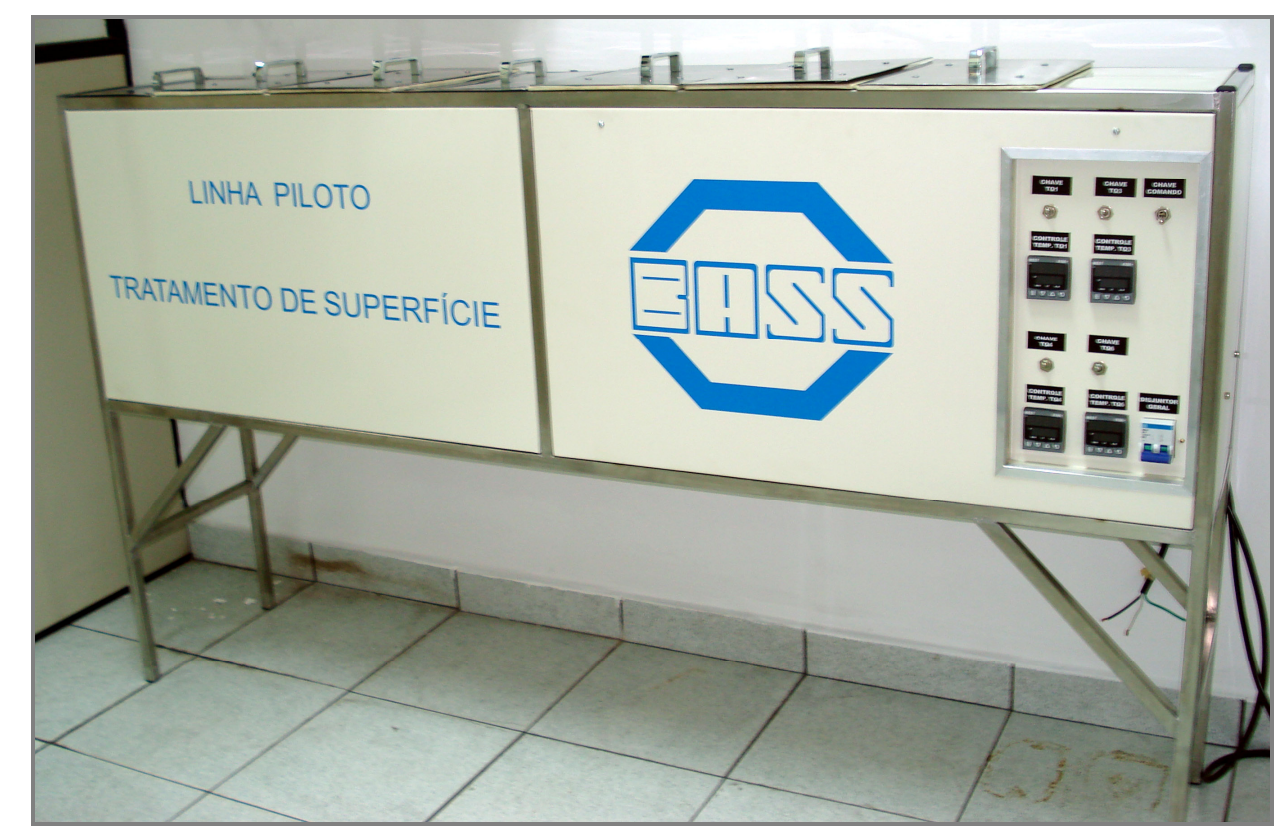

Figura 17. Linha piloto de fosfatização.

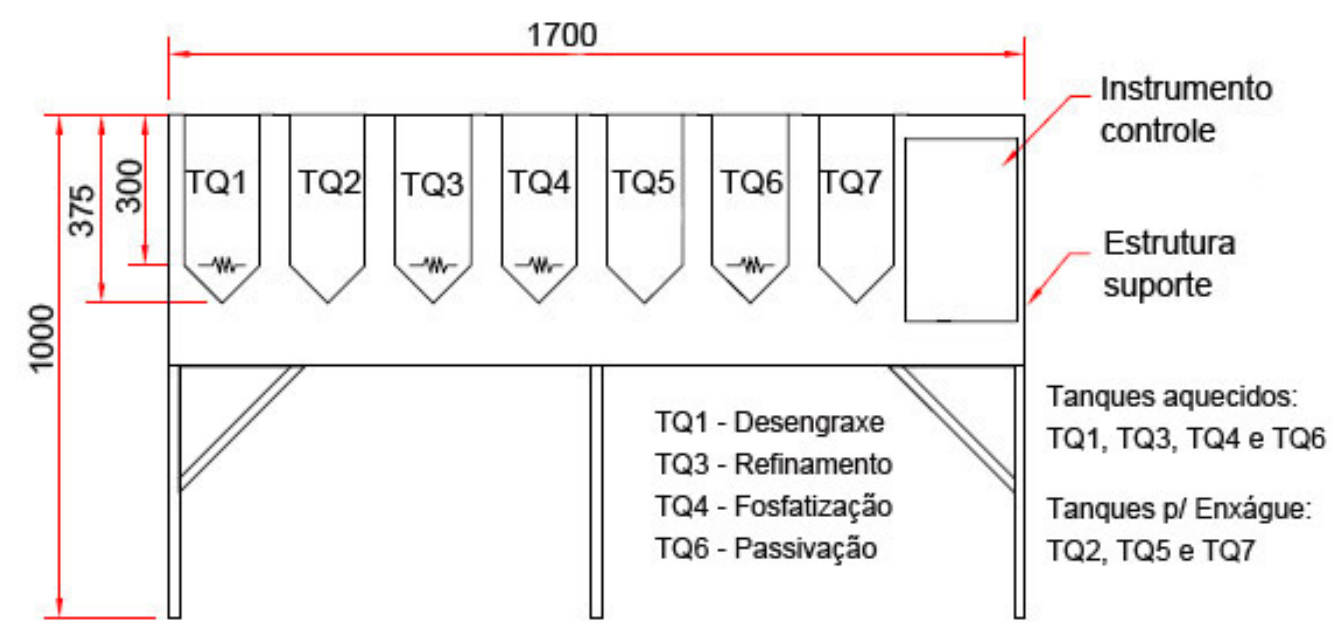

Figura 18. Projeto da linha piloto de fosfatização - vista frontal (dimensões em mm). 


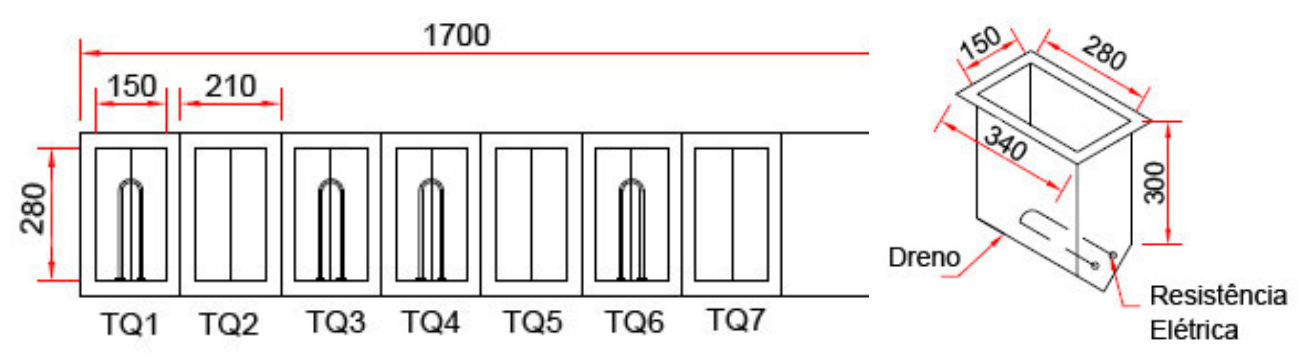

Figura 19. Projeto da linha piloto de fosfatização - vista superior e perspectiva isométrica do tanque interno (dimensões em $\mathrm{mm}$ ).

\subsubsection{Potenciostato e Frequencímetro}

Para os ensaios eletroquímicos foram utilizados os equipamentos Potenciostato/Galvanostato modelo $273 \mathrm{~A}$ da Princeton Applied Research ${ }^{\circledR}$ (PAR), e Frequencímetro modelo SI 1256 da Solartron ${ }^{\circledR}$. A Figura 20 ilustra estes equipamentos conectados a um microcomputador, através do qual e do software powerSUITE® se realizava o controle dos testes e a obtenção dos resultados.

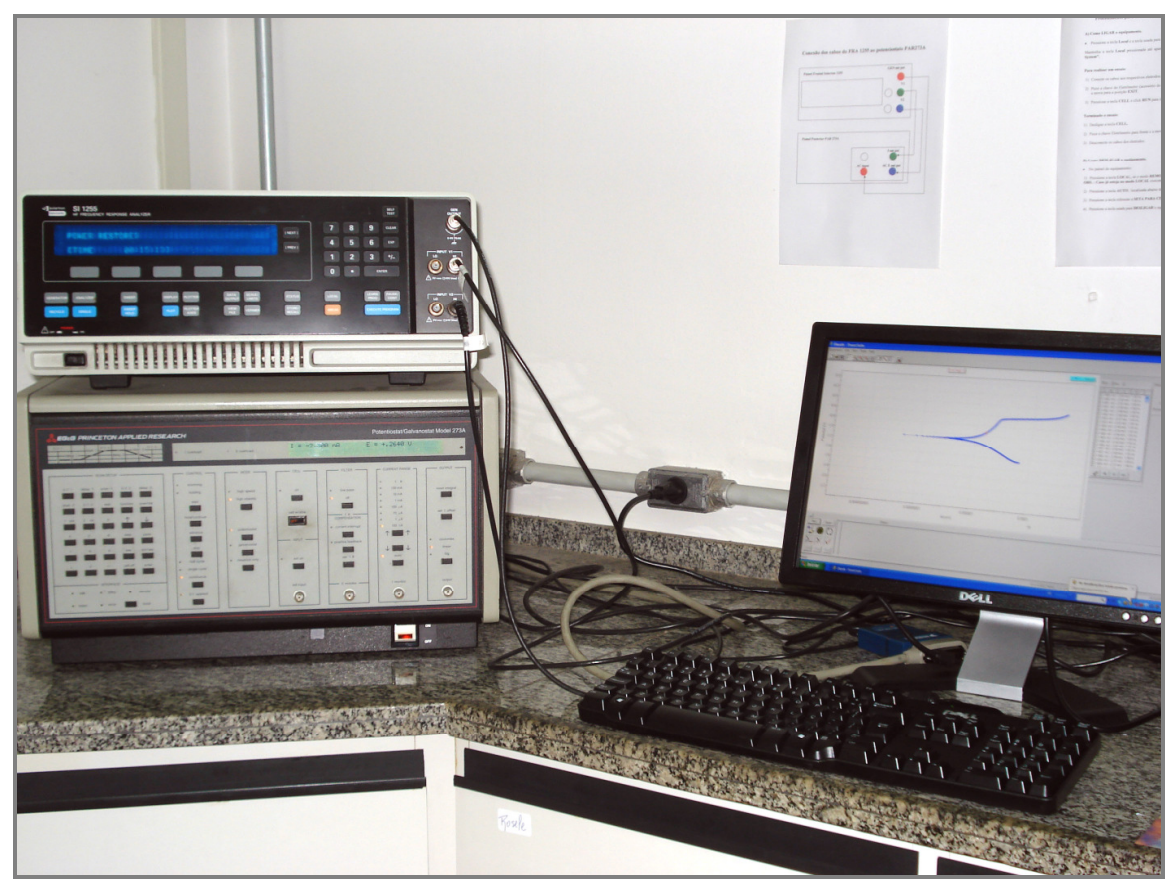

Figura 20. Potenciostato e frequencímetro conectados a microcomputador. 


\subsubsection{Células Eletroquímicas e Outros Acessórios}

Foram utilizados dois tipos de células para os testes eletroquímicos, a "Flat Cell" da EG\&G Princeton Applied Research ${ }^{\circledR}$, modelo K0235, e uma célula menor, com posicionamento da amostra na parte inferior. As Figuras 21 e 22 apresentam detalhes destas células. A região delimitada de exposição da amostra ao meio corrosivo é circular com diâmetro aproximado de $1,1 \mathrm{~cm}$, configurando uma área de $1,0 \mathrm{~cm}^{2}$.
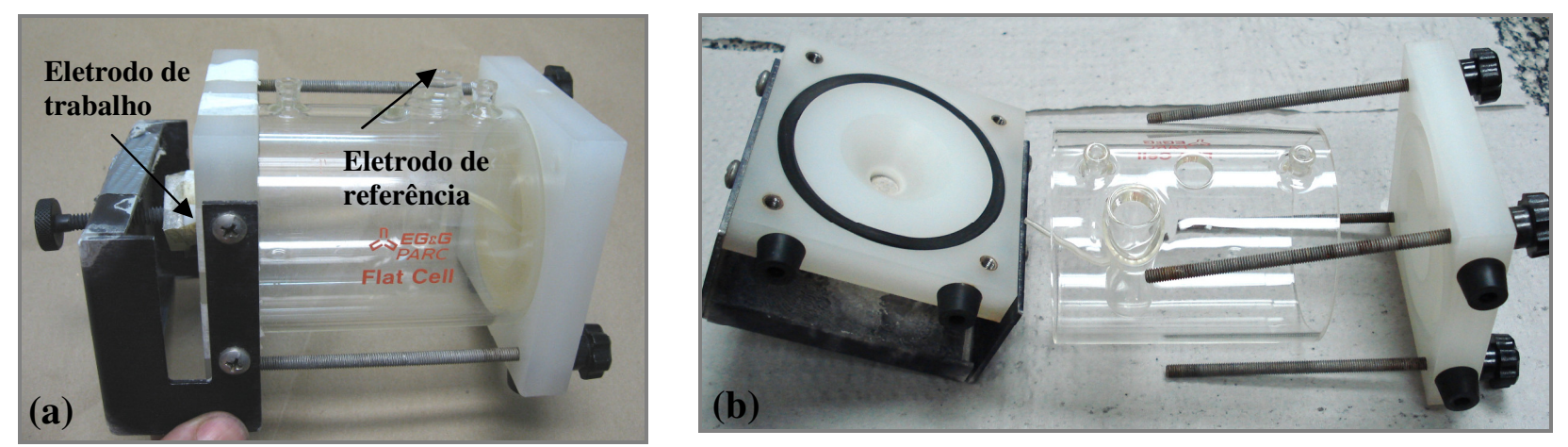

Figura 21. Foto da célula eletroquímica "flat cell" (a) montada, mostrando locais para os eletrodos de trabalho e de referência. (b) desmontada, mostrando orifícios e anel de vedação.

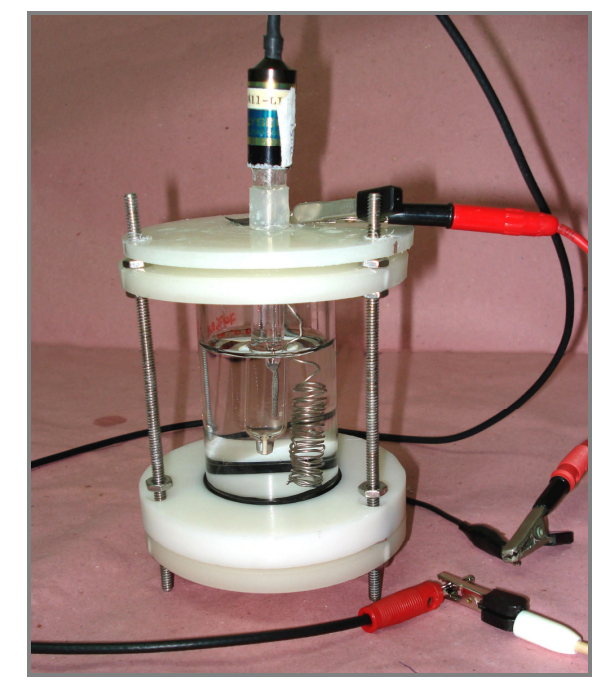

Figura 22. Célula eletroquímica com área de exposição da amostra na parte inferior, área circular igual a $1,0 \mathrm{~cm}^{2}$. Utilizada para ensaios de curta duração. 
Foi adotado o contra-eletrodo de platina em forma espiral, com área total de 23,6 $\mathrm{cm}^{2}$. Foi utilizado o eletrodo de referência de prata cloreto de prata $(\mathrm{Ag} / \mathrm{AgCl})$ em solução de cloreto de potássio $(\mathrm{KCl})$ saturado. A Figura 23 apresenta o eletrodo de referência e o contra-eletrodo utilizados neste trabalho.

(a)

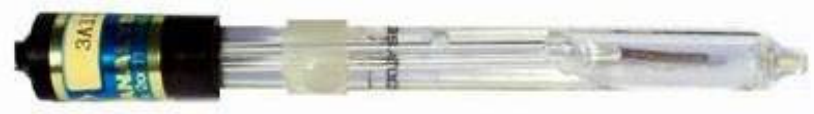

(b)

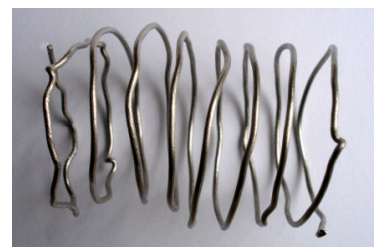

Figura 23. (a) Eletrodo de referência da Analyser ${ }^{\circledR}$ Ag/AgCl; (b) Contra-eletrodo de

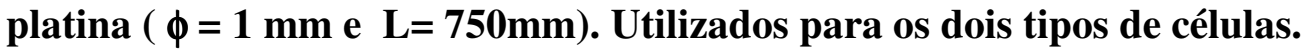

\subsubsection{Microscópio Eletrônico de Varredura e Difratômetro de Raios-X}

As micrografias apresentadas neste trabalho foram obtidas no microscópio eletrônico de varredura (MEV) da marca Philips modelo XL 30, do Departamento de Engenharia Metalúrgica e de Materiais da Poli/USP, sendo as imagens geradas através de elétrons secundários (ES).

A caracterização da superfície por difração de Raios-X foi efetuada através do método do pó $^{21}$, mediante o emprego de difratômetro de raios X, marca PANalytical, modelo X'Pert PRO com detector X'Celerator. As condições de análise foram: fonte geradora de raios $\mathrm{X}$ de cobre $(\mathrm{Cu})$, energia $45 \mathrm{kV}$, corrente de $40 \mathrm{~mA}$, intervalo angular $4^{\circ}$ à $70^{\circ}$, passo $0,02^{\circ}$, tempo/passo $10 \mathrm{~s}$, sistema spinner de rotação. A Figura 24 ilustra os referidos equipamentos.

\footnotetext{
${ }^{21}$ Os chamados métodos de difração de pó (powder diffraction) estão relacionados à difração de raios voltados aos estudos de materiais policristalinos. In:

http://www.angelfire.com/crazy3/qfl2308/1_multipart_xF8FF_2_DIFRACAO.pdf. Acessado em out/2009.
} 

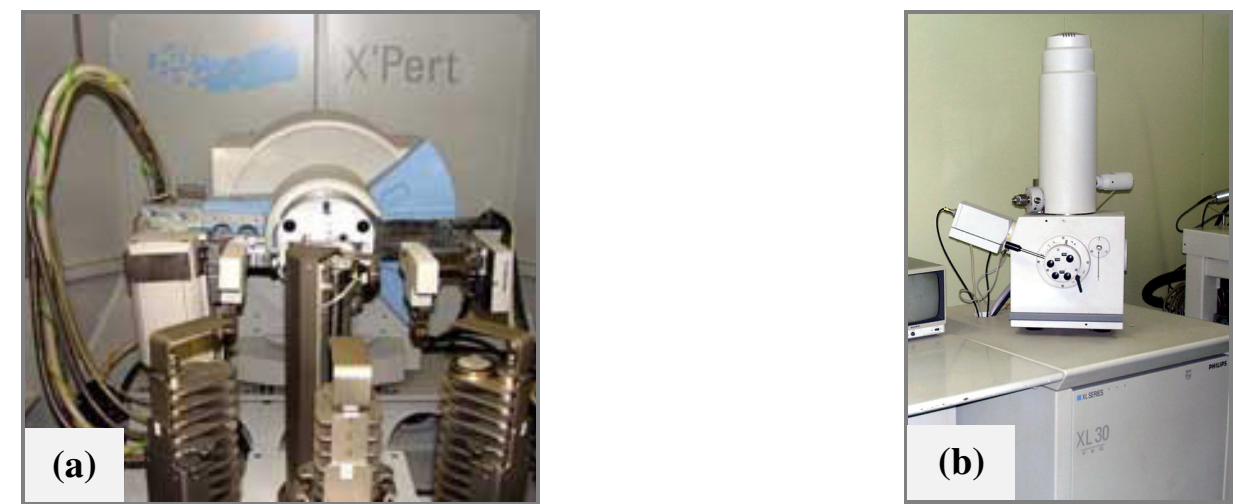

Figura 24. (a) Equipamento de difração de raios-X. (b) Microscópio eletrônico de varredura.

\subsubsection{Espectrômetro de Infravermelho}

Análises por espectroscopia de infravermelho foram realizadas com espectrômetro de infravermelho da Varian ${ }^{\circledR}$ modelo 660-IR, do Laboratório de Corrosão e Tratamento de Superfícies do Centro de Ciência e Tecnologia de Materiais (CCTM) do IPEN/CNEN-SP. Este equipamento foi adquirido e instalado durante o decorrer desta pesquisa. As leituras foram realizadas na faixa de infravermelho de 4000 a $400 \mathrm{~cm}^{-1}$, com 32 leituras por amostragem, sendo obtidas por refletância à $45^{\circ}$. O equipamento é controlado pelo programa "Resolutions Pro ${ }^{\mathrm{TM}}$ ". A Figura 25 apresenta o referido equipamento.

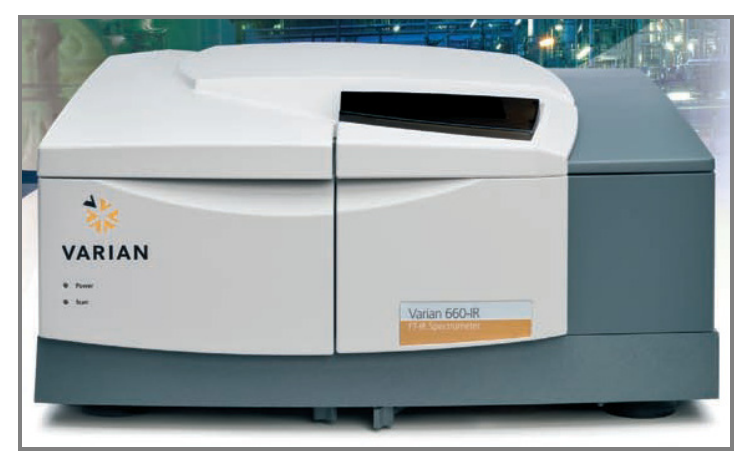

Figura 25. Espectrômetro de infravermelho. 


\subsection{Métodos Experimentais}

\subsubsection{Elaboração das Soluções para Fosfatização}

Os banhos de fosfatização foram elaborados a partir de uma solução concentrada também denominada no meio industrial de "xarope", sendo composta por uma mistura de reagentes. Este concentrado foi diluído e depois padronizado, antes de ser usado no processo de fosfatização.

Foi utilizado o oxalato de nióbio e amônio como aditivo no banho de fosfato em substituição ao níquel. Foram testadas duas concentrações de nióbio no banho, de acordo com condições iniciais testadas por BANCZEK (5 mg. $\mathrm{L}^{-1}$ e $50 \mathrm{mg} . \mathrm{L}^{-1}$ ) [2]. A morfologia da camada e recobrimento do substrato foram inicialmente avaliados por MEV. Foi considerada como melhor concentração de nióbio aquela que proporcionou a melhor cobertura superficial do substrato de aço.

Como acelerador no banho de fosfato foi utilizado o nitrito de sódio $\left(\mathrm{NaNO}_{2}\right)$ e para o tratamento de passivação foram utilizadas soluções de cromo hexavalente de uso comercial. As Tabelas 13 e 14 apresentam as composições das soluções concentradas do fosfato tricatiônico de zinco, níquel e manganês (com base na formulação industrial da Atlas Ind.) e do fosfato composto por zinco e manganês. Para composição do xarope de zinco e manganês, foram utilizados os mesmos percentuais do concentrado de $\mathrm{Zn}$, Mn e $\mathrm{Ni}$, porém sem a adição do carbonato de níquel.

Tabela 13. Composição da solução concentrada de fosfato tricatiônico com níquel.

\begin{tabular}{l|c|c}
\hline \multicolumn{3}{c}{ Composição (\% massa) } \\
\hline Ácido fosfórico & $\mathrm{H}_{3} \mathrm{PO}_{4}$ & 32 \\
\hline Ácido nítrico & $\mathrm{HNO}_{3}$ & 10 \\
\hline Óxido de zinco & $\mathrm{ZnO}$ & 15 \\
\hline Carbonato de manganês & $\mathrm{MnCO}_{3}$ & 3 \\
\hline Carbonato de níquel & $\mathrm{NiCO}_{3}$ & 2 \\
\hline Ácido fluorídrico & $\mathrm{HF}$ & 0,1 \\
\hline Peróxido de hidrogênio & $\mathrm{H}_{2} \mathrm{O}_{2}$ & 0,1 \\
\hline Água & $\mathrm{H}_{2} \mathrm{O}$ & 37,8 \\
\hline
\end{tabular}


Tabela 14. Composição da solução concentrada de fosfato de zinco e manganês, base para preparo do banho tricatiônico com nióbio.

\begin{tabular}{l|c|c}
\hline \multicolumn{3}{c}{ Composição (\% massa) } \\
\hline Ácido fosfórico & $\mathrm{H}_{3} \mathrm{PO}_{4}$ & 32 \\
\hline Ácido nítrico & $\mathrm{HNO}_{3}$ & 10 \\
\hline Óxido de zinco & $\mathrm{ZnO}$ & 15 \\
\hline Carbonato de manganês & $\mathrm{MnCO}_{3}$ & 3 \\
\hline Ácido fluorídrico & $\mathrm{HF}$ & 0,1 \\
\hline Peróxido de hidrogênio & $\mathrm{H}_{2} \mathrm{O}_{2}$ & 0,1 \\
\hline Água & $\mathrm{H}_{2} \mathrm{O}$ & 39,8 \\
\hline
\end{tabular}

O oxalato de nióbio e amônio não foi acrescido à solução concentrada, sendo adicionado após o preparo do banho e padronização do mesmo. Foram elaborados dois banhos de fosfatização, um contendo Zn, Mn e Ni e outro somente com Zn e Mn, sendo este último para estudos com e sem adição de oxalato de nióbio e amônio.

A preparação do banho de fosfato tricatiônico de zinco, manganês e níquel foi realizada através da mistura de $38,2 \mathrm{~mL}(60 \mathrm{~g})$ da solução concentrada de fosfato com 7,30 $\mathrm{mL}(10 \mathrm{~g})$ da solução de hidróxido de sódio - $\mathrm{NaOH}(50 \%)$, sendo adicionada água deionizada até completar $1000 \mathrm{~mL}$. Neste caso foi colocado aproximadamente $955 \mathrm{~mL}$ de água.

Para o banho preparado com o concentrado de zinco e manganês, as proporções foram: $953 \mathrm{~mL}$ de água deionizada somado a $39,7 \mathrm{~mL}$ da solução concentrada, somado a 7,30 mL de $\mathrm{NaOH}(50 \%)$. A densidade medida do concentrado de zinco e manganês foi de 1,51 g. $\mathrm{mL}^{-1}$.

\subsubsection{Padronização dos Banhos de Fosfatização (Ajuste da Acidez)}

Tanto a padronização inicial e posterior controle da acidez do banho irão garantir que se mantenha em solução a quantidade adequada de íons $\mathrm{H}^{+}$, pois estes íons participam das reações de início do processo de fosfatização mas são consumidos durante este.

Após preparo do banho foi feita a padronização para acertos da acidez total e acidez livre, conforme metodologia descrita a seguir. 
- Determinação da acidez total:

Adicionou-se a um erlenmeyer, $10 \mathrm{~mL}$ do banho onde foi acrescido $50 \mathrm{~mL}$ de água deionizada e cinco gotas de fenolftaleína. Em seguida titulou-se com uma solução de hidróxido de sódio $\left(0,1\right.$ mol. $\left.\mathrm{L}^{-1}\right)$, utilizando uma bureta, até a mudança de cor para violeta.

- Determinação da acidez livre:

Adicionou-se a um erlenmeyer $10 \mathrm{~mL}$ do banho de fosfato onde foi acrescido 50 $\mathrm{mL}$ de água deionizada e cinco gotas de azul de bromofenol. Em seguida titulou-se com uma solução de hidróxido de sódio a $0,1 \mathrm{~mol} . \mathrm{L}^{-1}$ usando uma bureta, até a mudança de cor para azul.

Após determinação dos valores de acidez livre e total, adicionou-se às soluções, $\mathrm{NaOH} 0,1 \mathrm{M}$ de modo a levar estes valores de acidez para padrões previamente definidos pelo fabricante. Foi adotada a seguinte relação para o cálculo da redução da acidez livre ${ }^{22}$ nos banhos de fosfato:

\section{0,4 g de $\mathrm{NaOH}$ reduz $1,0 \mathrm{~mL}$ na acidez livre, para cada 1 litro de banho.}

A quantidade requerida do $\mathrm{NaOH}$ foi adicionada na proporção em massa de 1:3, diluída em água. Após correção da acidez livre, verificou-se o valor da acidez total. A Tabela 15 apresenta os limites para a acidez livre e total para os banhos de fosfatos utilizados na pesquisa.

Tabela 15. Padrões para a acidez livre e total para os fosfatos compostos por Zn, Mn e Ni.

\begin{tabular}{c|c|c}
\hline Tipo de Fosfato & Acidez Livre & Acidez Total \\
\hline $\begin{array}{c}\mathrm{Zn}, \mathrm{Mn} \text { e Ni, com base no } \\
\text { concentrado laboratorial. }\end{array}$ & 1,5 a $2,0 \mathrm{~mL}$ & 25 a $30 \mathrm{~mL}$ \\
\hline $\begin{array}{c}\text { Zn, Mn e Ni a partir do } \\
\text { concentrado industrial. }\end{array}$ & 0,8 a $1,3 \mathrm{~mL}$ & 20 a $25 \mathrm{~mL}$ \\
\hline
\end{tabular}

\footnotetext{
${ }^{22}$ Relação atualmente adotada no meio industrial, fornecida pela Quimidream Ltda.
} 
Como já descrito, os concentrados de fosfato compostos com Zn, Mn e Ni serviram de base para elaboração dos banhos contendo composto de nióbio substituindo o níquel. Foi mantida a formulação original e, ao fosfato bicatiônico ( $\mathrm{Zn}, \mathrm{Mn}$ ) fornecido, foi adicionado oxalato de nióbio ao invés de níquel. Foram seguidos os mesmos padrões de acidez livre e total dos banhos com níquel, para os banhos com oxalato de nióbio e amônio.

Dois banhos foram tomados como referência durante a pesquisa. A Tabela 16 apresenta as especificações de cada um destes banhos.

Tabela 16. Banhos de fosfatização adotados neste trabalho.

\begin{tabular}{c|c|c|c|c}
\hline \multirow{2}{*}{ Empresa } & \multicolumn{4}{|c}{ Detalhamento } \\
\cline { 2 - 5 } & $\begin{array}{c}\text { Tipo do } \\
\text { fosfato }\end{array}$ & $\begin{array}{c}\text { Temperatura e } \\
\text { tempo de imersão } \\
\text { no banho }\end{array}$ & $\begin{array}{c}\text { Tipo e Percentual } \\
\text { do acelerador no } \\
\text { banho }\end{array}$ & $\begin{array}{c}\text { Tipo e } \\
\text { condições de } \\
\text { passivação }\end{array}$ \\
\hline $\begin{array}{c}\text { Concentrado } \\
\text { Laboratorial - } \\
\begin{array}{c}\text { Atlas Indústria de } \\
\text { Eletrodomésticos }\end{array}\end{array}$ & $\mathrm{Zn}, \mathrm{Mne} \mathrm{Ni}$ & $25^{\circ} \mathrm{C}$ por 5 minutos & $\begin{array}{c}\text { Nitrito de sódio } \\
0,5 \mathrm{~g} . \mathrm{L}^{-1}\end{array}$ & $\begin{array}{c}\text { Cromo } \\
\text { hexavalente }\end{array}$ \\
\hline $\begin{array}{c}\text { Concentrado } \\
\text { Industrial - } \\
\text { SurTec }\end{array}$ & $\mathrm{Zn}, \mathrm{Mn} \mathrm{e} \mathrm{Ni}$ & $50^{\circ} \mathrm{C}$ por 5 minutos & $\begin{array}{c}\text { Nitrito de sódio* } \\
0,3 \text { g.L } \mathrm{L}^{-1}\end{array}$ & $\begin{array}{c}\text { Cromo } \\
\text { hexavalente }\end{array}$ \\
\hline
\end{tabular}

* Conforme Boletim Técnico ST612 X.

** O passivador à base de cromo hexavalente foi elaborado e doado por esta empresa somente para os testes desta pesquisa, porém, este não está mais em uso comercial devido às restrições e problemas ambientais.

\subsubsection{Processo de Fosfatização}

O processo de fosfatização foi realizado como descrito a seguir, e está ilustrado na Figura 26. Este processo foi iniciado imediatamente após lixamento das amostras. A sequência a seguir apresenta as condições utilizadas para os banhos de referência, ou seja, aqueles com Zn, Mn e Ni. Os banhos desenvolvidos com adição de oxalato de nióbio e amônio encontram-se no capítulo de resultados. 


\section{$1^{a}$. Etapa - Desengraxe}

- Condições de desengraxe adotadas para processo de fosfatização com concentrado laboratorial:

Imersão das peças em solução com desengraxante à base de metassilicato de sódio na concentração de 50 g.L $\mathrm{L}^{-1}$ por 5 minutos. Solução aquecida entre $50{ }^{\circ} \mathrm{C}$ e $60{ }^{\circ} \mathrm{C}$.

- Condições de desengraxe adotadas para processo de fosfatização com concentrado industrial:

Imersão das peças em solução com desengraxante comercial DR 194-DS (SurTec) na concentração de 50 g.L. ${ }^{-1}$ por 5 minutos. Solução aquecida a $85^{\circ} \mathrm{C}$.

\section{Etapa - Enxágue}

- Imersão das placas em $1 \mathrm{~L}$ de água deionizada, por 10 segundos a $25^{\circ} \mathrm{C}$.

\section{$3^{\text {a }}$ Etapa - Refinamento}

- Condições de refinamento adotadas para processo de fosfatização com concentrado laboratorial:

Imersão das peças por 90 segundos na solução com o composto refinador de fosfato de titânio e sódio $\left(\mathrm{NaTi}_{2}\left(\mathrm{PO}_{4}\right)_{3}\right)$, na concentração de 3 g.L. ${ }^{-1}$. Solução aquecida entre $25^{\circ} \mathrm{C}$ e $30{ }^{\circ} \mathrm{C}$.

- Condições de desengraxe adotadas para processo de fosfatização com concentrado industrial:

Imersão das peças por 60 segundos na solução com o composto refinador SurTec $610 \mathrm{~V}$ (a base de sais complexos de titânio), na concentração de 2 g. $\mathrm{L}^{-1}$. Solução aquecida a $30{ }^{\circ} \mathrm{C}$. 


\section{4a. Etapa - Fosfatização}

- Condições de fosfatização adotadas para processo de fosfatização com concentrado laboratorial:

Imersão na solução de fosfato (banho padronizado do fosfato $\mathrm{Zn}, \mathrm{Mn}, \mathrm{Ni}$ ) com o acelerador de nitrito de sódio na concentração de 0,5 g.L. $\mathrm{L}^{-1}$, aquecida a $25{ }^{\circ} \mathrm{C}$. O tempo de imersão determinado pelo teste gravimétrico foi de 5 minutos.

- Condições de fosfatização adotadas para processo de fosfatização com concentrado industrial:

Imersão na solução de fosfato (banho de fosfato $\mathrm{Zn}, \mathrm{Mn}$, Ni de base industrial) com o acelerador de nitrito de sódio na concentração de 0,3 g.L $\mathrm{L}^{-1}$, a $50{ }^{\circ} \mathrm{C}$, por 5 minutos.

\section{5a. Etapa - Enxágue}

- Imersão das placas em $1 \mathrm{~L}$ de água deionizada, por 10 segundos a $25^{\circ} \mathrm{C}$.

\section{6 ${ }^{a}$ Etapa - Passivação com $\mathrm{CrO}_{3}$}

- Solução utilizada para processo de fosfatização com concentrado laboratorial: Imersão na solução de $\mathrm{CrO}_{3}$ na concentração de $200 \mathrm{mg} \cdot \mathrm{L}^{-1}$ a $(35 \pm 2){ }^{\circ} \mathrm{C}$ por 60 segundos.

- Solução utilizada para processo de fosfatização com concentrado industrial: Imersão em solução de cromo hexavalente (passivador Dream $\mathrm{N}^{\mathrm{o}}$ 401-A, SurTec), com concentração de $0,03 \%$ v/v, por 60 segundos à temperatura de $25^{\circ} \mathrm{C}$.

\section{Etapa - Enxágue}

- Imersão das placas em $1 \mathrm{~L}$ de água deionizada, por 10 segundos a $25{ }^{\circ} \mathrm{C}$. Seguida por lavagem em álcool e secagem com ar quente 
A Figura 26 ilustra a sequencia de etapas envolvidas no processo de fosfatização tricatiônica, adotada neste trabalho.

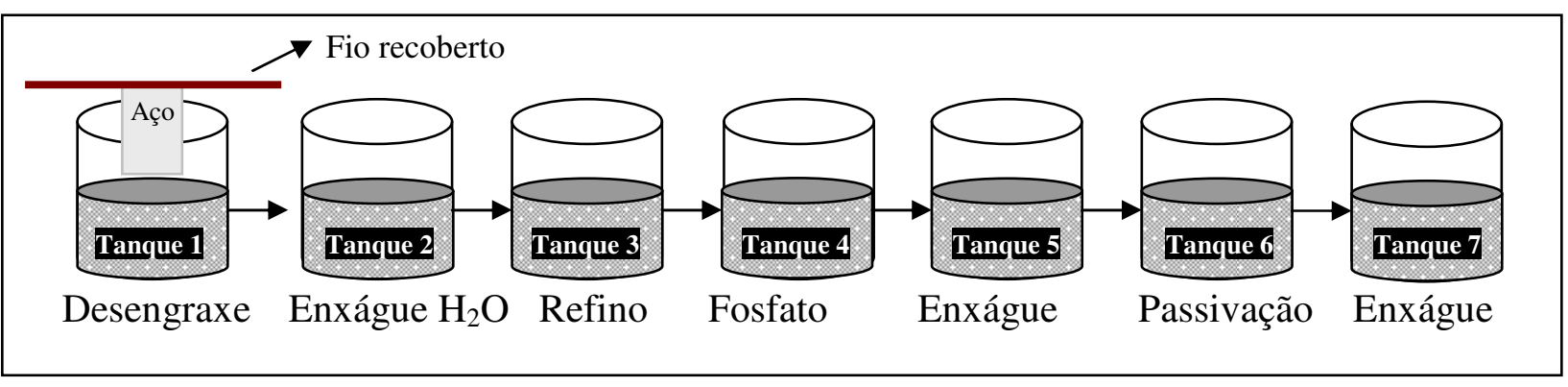

Figura 26. Ilustração da sequencia de fosfatização tricatiônica adotada.

As amostras fosfatizadas foram mantidas em dessecador até o momento de serem utilizadas nos ensaios de caracterização.

\subsubsection{Ensaio Gravimétrico}

O ensaio gravimétrico teve como objetivo a escolha do tempo de imersão nos banhos de fosfatização que resultasse no melhor compromisso entre maior massa de fosfato depositada e menor tempo de fosfatização. A norma ASTM B767-88 define a metodologia do referido teste [75].

A massa do revestimento de fosfato é determinada pela pesagem da amostra antes e depois de se dissolver este revestimento em um reagente que não ataque o substrato. Inicialmente, a área (A) da placa de aço foi determinada sendo realizadas quatro medidas em cada dimensão da placa, considerando-se a média aritmética destas. A placa foi então lavada com água e álcool e secada. Após deposição da camada de fosfato, a amostra foi pesada determinando-se a massa $\left(\mathrm{m}_{1}\right)$.

Em seguida foi feito o tratamento para dissolver a camada de fosfato, utilizando-se uma solução de 50 g. $\mathrm{L}^{-1}$ de $\mathrm{CrO}_{3}$, na qual as chapas são imersas por 15 minutos a uma temperatura de $(75 \pm 5)^{\circ} \mathrm{C}$. Após este período, as chapas foram removidas da solução, lavadas, secadas, e novamente pesadas, obtendo-se a massa $\left(\mathrm{m}_{2}\right)$. A massa de fosfato $\left(\mathrm{m}_{\text {fosfato }}\right)$ por unidade de área $(\mathrm{A})$, em $\mathrm{mg} \cdot \mathrm{cm}^{-2}$, do revestimento de fosfato depositada é dada pela Equação 13: 


$$
\mathrm{m}_{\text {fosfato }}=\frac{\mathrm{m}_{1}-\mathrm{m}_{2}}{\mathrm{~A}}
$$

Neste trabalho, foram realizadas medidas gravimétricas da camada de fosfato obtidas para períodos de fosfatização entre 1 e 10 minutos. Os resultados estão apresentados em gráficos de massa (massa da camada em g.m ${ }^{-2}$ ) versus tempo de fosfatização (em minutos).

\subsubsection{Desenvolvimento de Solução para Fosfatização Substituindo Níquel por Composto de Nióbio}

Uma das contribuições deste trabalho consistiu no desenvolvimento de uma solução de fosfatização isenta de níquel, sendo este substituído por um composto de nióbio sem restrições ambientais. Foram testadas mais de uma composição com o objetivo de selecionar as melhores condições experimentais. Os detalhes experimentais da preparação destas soluções estão indicados nos itens 5.4.1 e 5.4.2. Após a fosfatização de amostras de aço nas soluções com composto de nióbio em substituição ao níquel, as superfícies foram observadas por MEV, e os resultados encontram-se nos itens 6.1.2 a 6.1.4.

Inicialmente foram preparados dois banhos de fosfato tricatiônico com zinco e manganês e, após padronização, foi acrescido em cada um, uma concentração diferente de nióbio, a saber: $5 \mathrm{mg} . \mathrm{L}^{-1}$ e $50 \mathrm{mg} . \mathrm{L}^{-1}$ [2]. As camadas de fosfato com estes banhos foram obtidas nas mesmas condições utilizadas para o banho padrão com fosfato tricatiônico (Ftric Zn,Mn,Ni), ou seja, cinco minutos de imersão em banho a $25{ }^{\circ} \mathrm{C}$ e acelerador de $\mathrm{NaNO}_{2}$ na concentração de $0,5 \mathrm{~g} \cdot \mathrm{L}^{-1}$.

\subsubsection{Ensaios Eletroquímicos}

Nos ensaios eletroquímicos, especificamente de espectroscopia de impedância eletroquímica e polarização potenciodinâmicas, foi adotada uma solução de 0,5 mol.L ${ }^{-1}$ de cloreto de sódio. Foi usado como eletrodo de referência $\mathrm{Ag} / \mathrm{AgCl}, \mathrm{KCl}$ saturado, e como contra eletrodo, fio de platina. 
Para cada condição em estudo, foram realizadas entre quatro e doze repetições. As medidas de variação do potencial de circuito aberto em função do tempo foram realizadas por 2 horas, para avaliar a estabilidade do potencial antes da realização dos ensaios de espectroscopia de impedância eletroquímica. A faixa de frequência investigada nestes testes foi de $10 \mathrm{kHz}$ a $10 \mathrm{mHz}$, e a amplitude adotada foi de $20 \mathrm{mV} / \mathrm{rms}$, com uma taxa de aquisição de dados de 10 pontos por década.

As curvas de polarização catódica das amostras foram obtidas após o ensaio de espectroscopia de impedância eletroquímica, desde o potencial de circuito aberto até um potencial de $-0,500 \mathrm{~V}$ em relação ao potencial de circuito aberto. As curvas de polarização anódica foram obtidas do potencial de circuito aberto até $+0,500 \mathrm{~V}$ em relação a este potencial. A velocidade de varredura adotada para as curvas de polarização anódica e catódica foi de $0,166 \mathrm{mV} \mathrm{s}^{-1}$, em meio de $\mathrm{NaCl} 0,5 \mathrm{~mol} \cdot \mathrm{L}^{-1}$.

Para avaliação do efeito do tratamento de passivação, foram fosfatizadas amostras de aço carbono 1005 com o banho de fosfato de zinco, manganês e nióbio. Após fosfatização, a influência da concentração do nióbio no banho, em relação à resistência à corrosão, foi avaliada por cronoamperometria. Como referência de comparação, foi adotada solução com o passivador Dream 401-A, à base de cromo hexavalente. O tratamento de passivação consistiu na imersão de placas fosfatizadas em soluções tamponadas com pH igual a 6 e 8 [76] e em solução com $\mathrm{CrO}_{3}$. Foi acrescido nióbio às soluções tamponadas em duas concentrações, $200 \mathrm{mg} . \mathrm{L}^{-1}$ e $400 \mathrm{mg} . \mathrm{L}^{-1}$. A Tabela 17 relaciona a quantidade de amostras submetidas à cronoamperometria com as soluções usadas neste teste. 
Tabela 17. Amostras e soluções adotadas nos testes de cronoamperometria.

\begin{tabular}{|c|c|c|c|c|}
\hline \multirow{2}{*}{ pH } & \multirow{2}{*}{\multicolumn{3}{|c|}{$\begin{array}{c}\text { Composição das Soluções Tamponadas } \\
\text { (eletrólitos) }\end{array}$}} & $\begin{array}{c}\text { Aço com fosfato } \\
\text { ST617 Zn,Mn+Nb }\end{array}$ \\
\hline & & & & $\begin{array}{c}\text { Quantidade de Amostras - } \\
\text { Repetições }\end{array}$ \\
\hline \multirow{3}{*}{8} & \multirow{3}{*}{$\begin{array}{c}\text { Solução tampão: } \\
\mathrm{KH}_{2} \mathrm{PO}_{4} 0,1 \mathrm{M}-500 \mathrm{~mL} \\
+\mathrm{NaOH} \quad 0,1 \mathrm{M}-468 \mathrm{~mL}\end{array}$} & \multicolumn{2}{|c|}{$\mathrm{Sem} \mathrm{Nb}$} & 4 \\
\hline & & \multirow{2}{*}{$\begin{array}{c}\text { Com } \\
\mathrm{Nb}\end{array}$} & $200 \mathrm{mg} \cdot \mathrm{L}^{-1}$ & 4 \\
\hline & & & $400 \mathrm{mg} \cdot \mathrm{L}^{-1}$ & 4 \\
\hline \multirow{3}{*}{6} & \multirow{3}{*}{$\begin{array}{c}\text { Solução tampão: } \\
\mathrm{KH}_{2} \mathrm{PO}_{4} 0,1 \mathrm{M}-500 \mathrm{~mL} \\
+\mathrm{NaOH} \quad 0,1 \mathrm{M}-57 \mathrm{~mL}\end{array}$} & \multicolumn{2}{|c|}{$\mathrm{Sem} \mathrm{Nb}$} & 4 \\
\hline & & \multirow{2}{*}{$\begin{array}{c}\mathrm{Com} \\
\mathrm{Nb}\end{array}$} & $200 \mathrm{mg} \cdot \mathrm{L}^{-1}$ & 4 \\
\hline & & & $400 \mathrm{mg} . \mathrm{L}^{-1}$ & 4 \\
\hline 4 & \multicolumn{3}{|c|}{$\mathrm{CrO}_{3}($ Dream $401-\mathrm{A}, 0,03 \% \mathrm{v} / \mathrm{v})$} & 4 \\
\hline & & & & Total \\
\hline
\end{tabular}

As curvas cronoamperométricas foram obtidas a partir do potencial de circuito aberto - PCA (potencial de imersão), a uma sobretensão anódica de $50 \mathrm{mV}$, por 1800 segundos. A partir dos resultados, foi selecionada a solução onde a curva cronoamperométrica apresentou menor corrente de corrosão. Amostras de aço foram então fosfatizadas ( $\mathrm{ST617} \mathrm{Zn}, \mathrm{Mn}+\mathrm{Nb}$ ) e passivadas na solução selecionada com composto de nióbio, e em seguida foram submetidas a ensaios eletroquímicos (polarização e impedância) em meio de $\mathrm{NaCl}\left(0,2 \mathrm{~mol} \cdot \mathrm{L}^{-1}\right)$, comparando-se com a passivação em solução de cromo hexavalente.

\subsubsection{Caracterização Química e Morfológica das Camadas Fosfatizadas}

\subsubsection{Microscopia Eletrônica de Varredura (MEV)}

Após a fosfatização das amostras, as camadas de fosfato obtidas para cada condição testada foram observadas por microscopia eletrônica de varredura (MEV), avaliando-se a cobertura do substrato e a morfologia dos cristais. 


\subsubsection{Determinação da Composição da Camada de Fosfato}

Através da análise semiquantitativa por espectroscopia de energia dispersiva (EDS) foram indicados os elementos presentes nas camadas de fosfato. As fases presentes no fosfato foram avaliadas por difração de Raios-X. A técnica de espectroscopia de infravermelho (FT-IR) também foi utilizada para determinação da composição dos revestimentos de fosfato. A técnica de espectroscopia tem extensa aplicação na identificação dos compostos em análise.

\subsubsection{Estimativa da Espessura de Camada}

Foram utilizadas placas com dimensões de $75 \mathrm{~mm}$ x $150 \mathrm{~mm}$, fosfatizadas para o ensaio de corrosão acelerada. Sobre estas superfícies fosfatizadas, com e sem pintura, foram realizadas quatro medidas em um lado de cada placa, sendo realizadas três repetições para cada tipo de fosfato. Foi utilizado o aparelho da Fischer Technology ${ }^{\circledR}$, modelo DualScope ${ }^{\circledR}$ USB MP0R portátil (Figura 27).

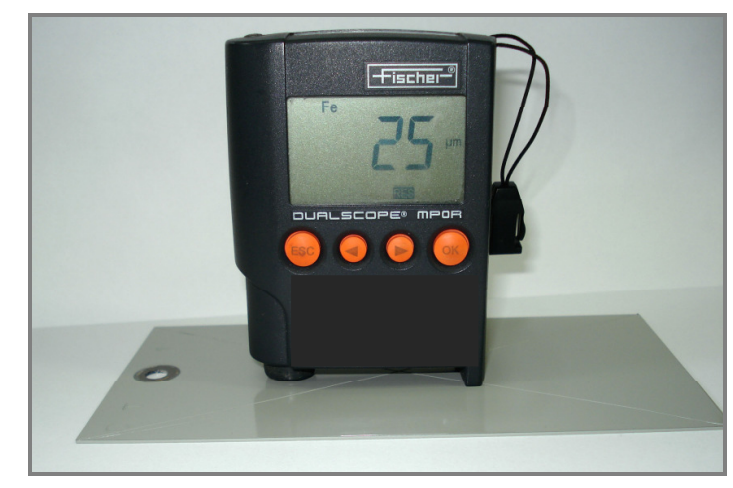

Figura 27. Aparelho utilizado para estimativa da espessura dos revestimentos

(Fischer).

\subsubsection{Passivação com Oxalato de Nióbio e Amônio}

Amostras fosfatizadas em banho de zinco, manganês e nióbio foram passivadas com passivador Dream 401-A e em soluções contendo oxalato de nióbio e amônio, e o desempenho foi avaliado pela técnica de cronoamperometria. 


\subsubsection{Ensaio de Névoa Salina e Determinação da Aderência de Tintas}

Para os ensaios de névoa salina e aderência foram utilizadas placas de aço carbono (SAE 1005) com dimensões de $75 \mathrm{~mm}$ x $150 \mathrm{~mm}$ fosfatizadas no Laboratório de Corrosão e Tratamento de Superfícies do IPEN e, posteriormente recobertas com pintura eletroforética (KTL) em linha industrial. Estas amostras foram levadas para avaliação de resistência à corrosão em câmaras de névoa salina em laboratório de corrosão industrial, onde ficaram expostas por 504 horas. As normas utilizadas como referência foram a ASTM B117/09 para corrosão e NBR 11003/09 para aderência [77, 78]. A Tabela 18 apresenta os tipos de amostras usadas neste ensaio.

Tabela 18. Definição das amostras para o teste de névoa salina.

\begin{tabular}{c|c}
\hline Tipo de Amostra & $\mathbf{N}^{\mathbf{0}}$ de Amostras \\
\hline Aço carbono 1005 & 3 \\
\hline Aço com fosfato ST617 Zn,Mn,Ni & 3 \\
\hline Aço com fosfato ST617 Zn,Mn+Nb & 3 \\
\hline
\end{tabular}




\section{RESULTADOS OBTIDOS COM CONCENTRADO LABORATORIAL}

Todos os resultados apresentados neste capítulo referem-se às camadas obtidas com o fosfato tricatiônico de zinco, manganês e níquel (Ftric Zn,Mn,Ni), zinco, manganês e nióbio (Ftric $\mathrm{Zn}, \mathrm{Mn}+\mathrm{Nb}$ ) e zinco e manganês (Fbic $\mathrm{Zn}, \mathrm{Mn}$ ) cujo concentrado foi elaborado em laboratório com base em composição industrial.

\subsection{Definição das Condições de Fosfatização para o Banho Contendo Zn, Mn e Nb}

Através de ensaio gravimétrico e análises por MEV foram definidas condições experimentais para execução da fosfatização em banho com Zn, Mn e Nb. Os resultados estão apresentados a seguir.

\subsubsection{Ensaio Gravimétrico para Camada Obtida com Fosfato de Zn, Mn e Ni}

O ensaio gravimétrico foi realizado com o objetivo de se determinar o tempo de imersão do aço no banho de fosfato, e foi utilizado para as camadas obtidas com o banho padrão de fosfato de zinco, níquel e manganês, com o tempo de imersão variando de 1 a 9 minutos. Os resultados obtidos são apresentados na Figura 28. Nota-se que o tempo para estabilização da camada foi cerca 5 minutos e, portanto, este também foi utilizado para fosfatização em banho de fosfato tricatiônico com zinco, manganês e nióbio (item 6.1.2). Para o tempo de 5 minutos foi encontrado o valor de massa por área de 2,5 g.m $\mathrm{m}^{-2}$. 


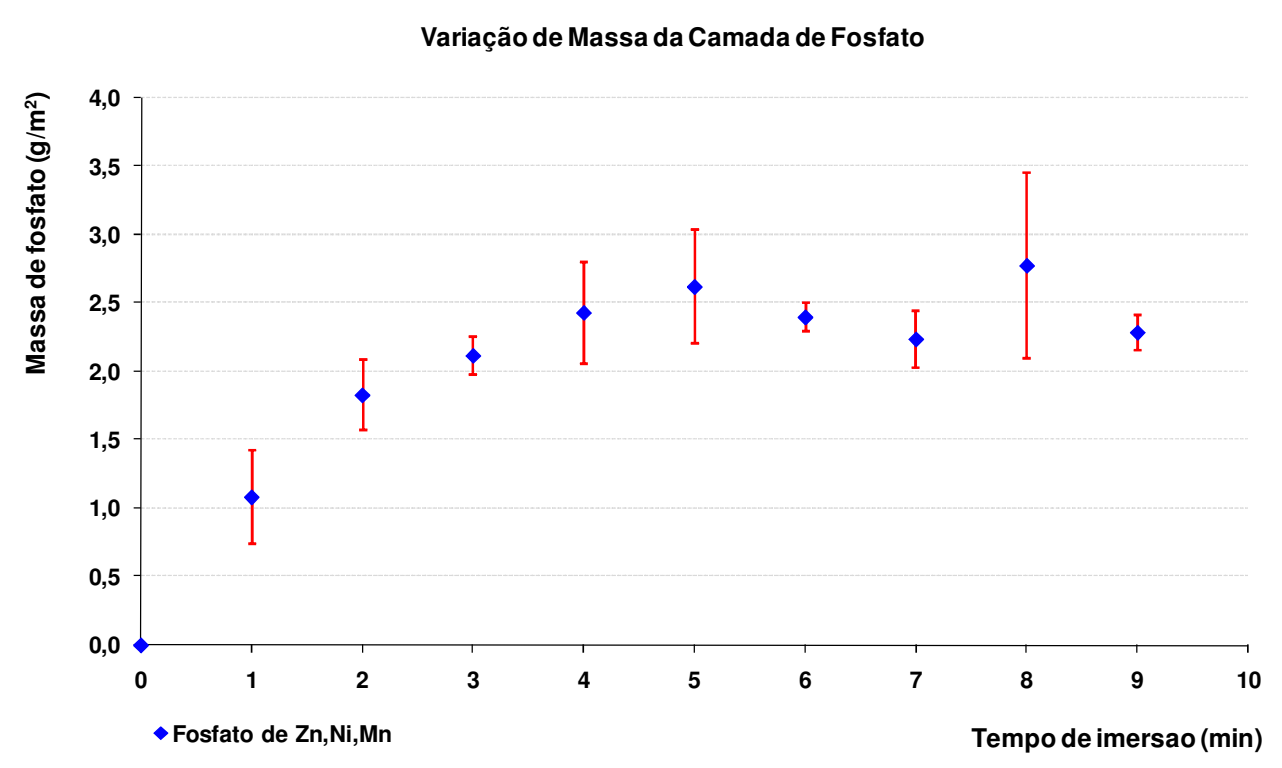

Figura 28. Variação de massa de fosfato em função do tempo de imersão no banho de fosfatização de Zn, Mn e Ni.

6.1.2. Micrografias por $\mathrm{MEV}$ das camadas de fosfato de $\mathrm{Zn}$, Mn e $\mathrm{Nb}$, com variação da concentração de $\mathrm{Nb}\left(5\right.$ e 50 mg.L $\left.{ }^{-1}\right)$

A superfície das amostras fosfatizadas por imersão durante 5 minutos a $25^{\circ} \mathrm{C} \mathrm{em}$ banho de fosfato tricatiônico de $\mathrm{Zn}, \mathrm{Mn}, \mathrm{Nb}$ ( com 0,5 g.L $\mathrm{L}^{-1}$ do acelerador $\mathrm{NaNO}_{2}$ ), para as duas concentrações de nióbio, foi observada por MEV e as micrografias obtidas são mostradas na Figura 29 (a) para a concentração de nióbio igual a 5 mg.L $\mathrm{L}^{-1}$ e (b) para a concentração de nióbio igual a 50 mg. $\mathrm{L}^{-1}$. 

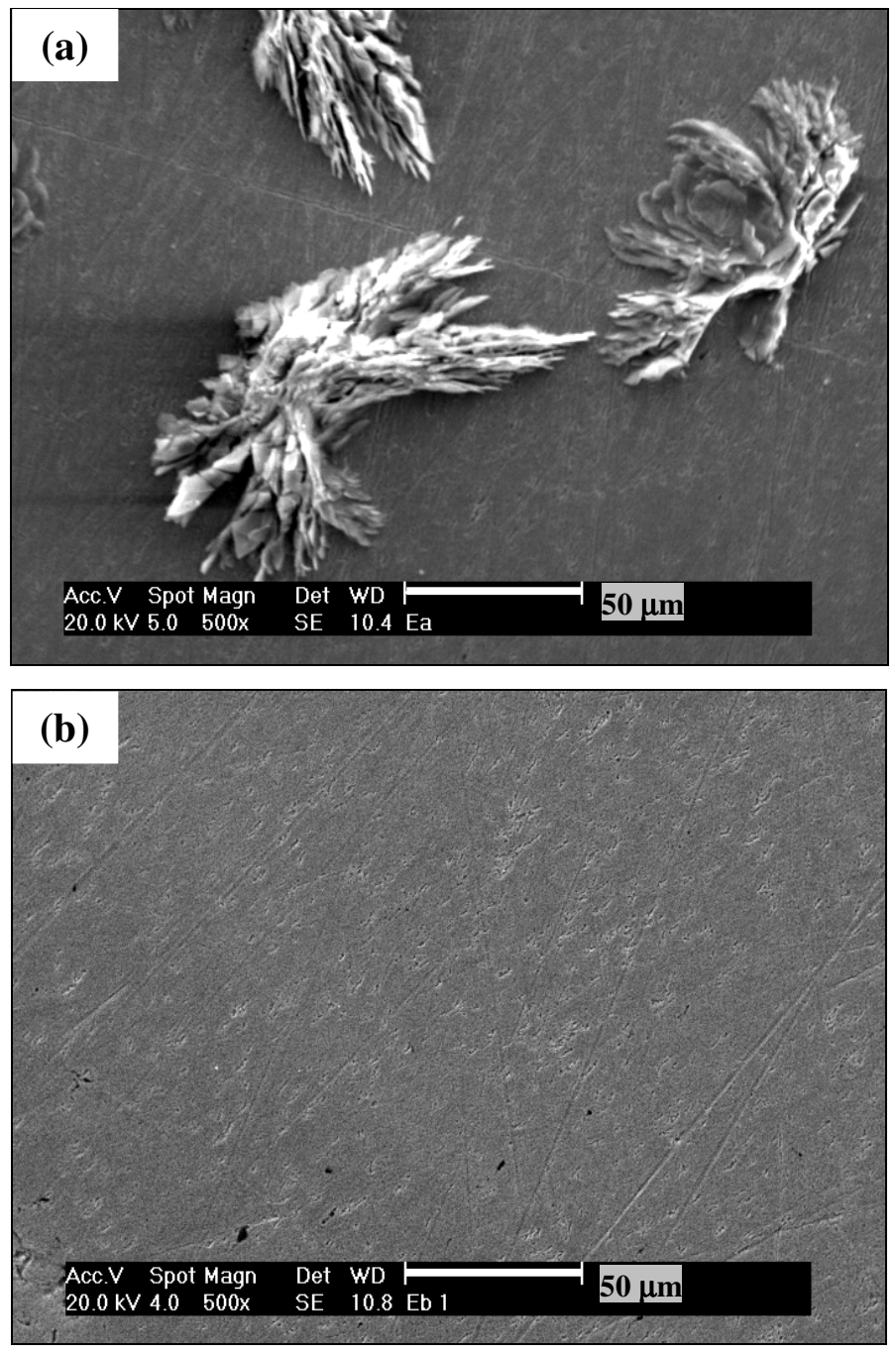

Figura 29. Micrografias por MEV da superfície do aço após imersão por 5 minutos em banho de fosfato tricatiônico ( $\mathrm{Zn}, \mathrm{Mn}, \mathrm{Nb}$ ), com teor de $\mathrm{Nb}$ de (a) 5 mg.L $\mathrm{L}^{-1}$ e (b) 50 mg. $\mathbf{L}^{-1}$.

Pelas micrografias apresentadas verifica-se que a adição de nióbio ao banho na concentração de $50 \mathrm{mg} \cdot \mathrm{L}^{-1}$, não permitiu a fosfatização da superfície, não sendo observado cristais de fosfato depositado. Consequentemente, foi adotada a concentração de $5 \mathrm{mg} . \mathrm{L}^{-1}$ de nióbio nos banhos de fosfatização para continuidade desta pesquisa.

O oxalato de nióbio e amônio favorece a formação de película passivadora na superfície do aço. Isto explica a ausência de cristais de fosfato no substrato quando foi aumentada a concentração de nióbio de 5 para $50 \mathrm{mg} . \mathrm{L}^{-1}$, ou seja, a superfície do aço foi passivada dificultando seu ataque corrosivo e consequente fosfatização com formação de 
cristais de fosfato. Este comportamento também foi observado por BANCZEK em sua pesquisa com fosfato de zinco [2].

Devido à cobertura da superfície do substrato pelo fosfato obtido na solução com concentração de nióbio de $5 \mathrm{mg} . \mathrm{L}^{-1}$ não ter sido satisfatória, foram testadas outras condições de fosfatização, variando-se a temperatura e a concentração do acelerador. Estas alterações nas condições de fosfatização tiveram o objetivo de causar o rompimento da camada passiva de óxido formada na superfície, possibilitando uma melhor cobertura cristalina.

A Tabela 19 apresenta as condições testadas para o banho de fosfato de $\mathrm{Zn}, \mathrm{Mn}, \mathrm{Nb}$ com 5 mg. $\mathrm{L}^{-1}$ de nióbio.

Tabela 19. Condições testadas para o banho de fosfatização de $\mathrm{Zn}, \mathrm{Mn}, \mathrm{Nb}$.

\begin{tabular}{l|l}
\hline Variáveis & Especificações \\
\hline Temperatura & $25^{\circ} \mathrm{C}$ e $50{ }^{\circ} \mathrm{C}$ \\
\hline Concentração do acelerador $\mathrm{NaNO}_{2}$ & 1,$0 ; 1,5$ e 2,0 g.L.- \\
\hline Tempo de imersão & 3 e 5 minutos \\
\hline
\end{tabular}

As especificações adotadas para as variáveis apresentadas na Tabela 19 foram baseadas em banhos comerciais de fosfato tricatiônico utilizados em indústrias automobilísticas em São Paulo, onde a temperatura do banho de fosfato normalmente varia entre $45^{\circ} \mathrm{C}$ e $55^{\circ} \mathrm{C}$, e o tempo da ordem de minutos. Foram testadas os mesmos teores do acelerador $\mathrm{NaNO}_{2}$ utilizados por BANCZEK, para o fosfato de zinco com adição de $\mathrm{Nb}$ [2]. 
6.1.3. Micrografias por MEV do efeito da temperatura e concentração de $\mathrm{NaNO}_{2}$ na morfologia da camada de fosfato de zinco, manganês e nióbio.

Nas Figuras 30 e 31 são apresentadas micrografias de amostras fosfatizadas em banhos de $\mathrm{Zn}, \mathrm{Mn}$ e Nb, para as temperaturas de $25^{\circ} \mathrm{C}$ e $50^{\circ} \mathrm{C}$, durante 3 e 5 minutos de imersão, respectivamente.
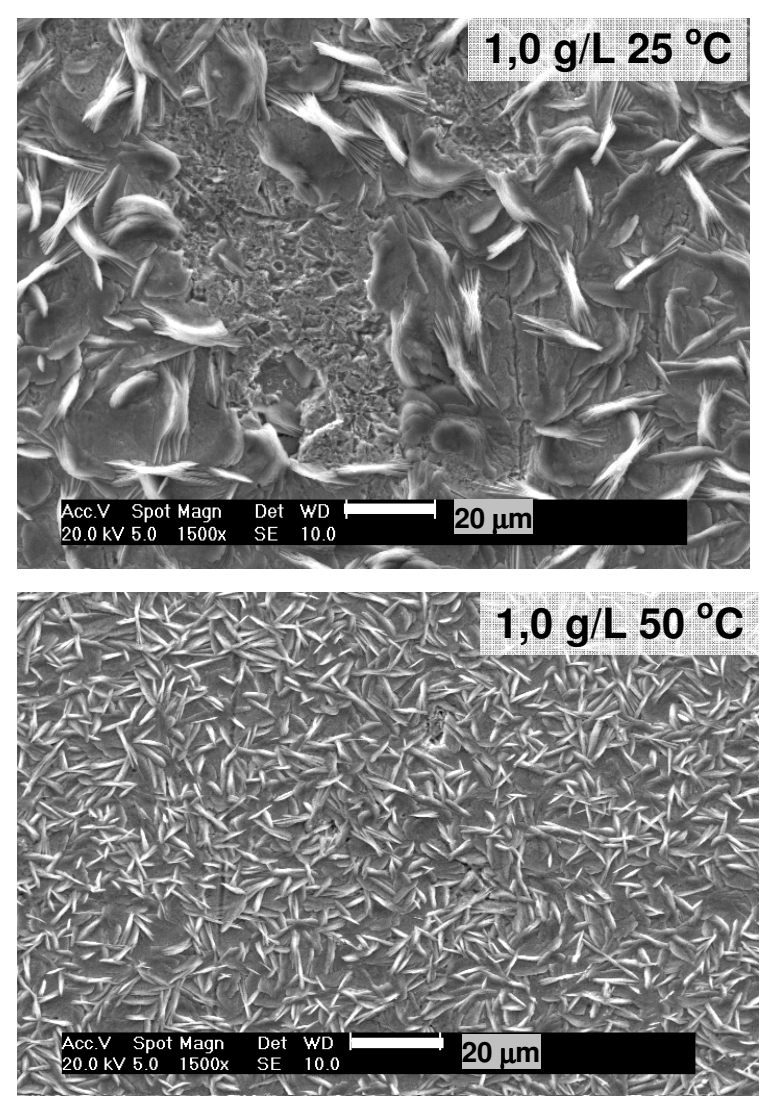

Figura 30. Camadas de fosfato de $\mathrm{Zn}$, Mn e $\mathrm{Nb}\left(5 \mathrm{mg} . \mathrm{L}^{-1}\right)$ obtidas para 3 minutos de imersão em banho de fosfato com várias concentrações de $\mathrm{NaNO}_{2}$ a $25^{\circ} \mathrm{C}$ e $50{ }^{\circ} \mathrm{C}$.
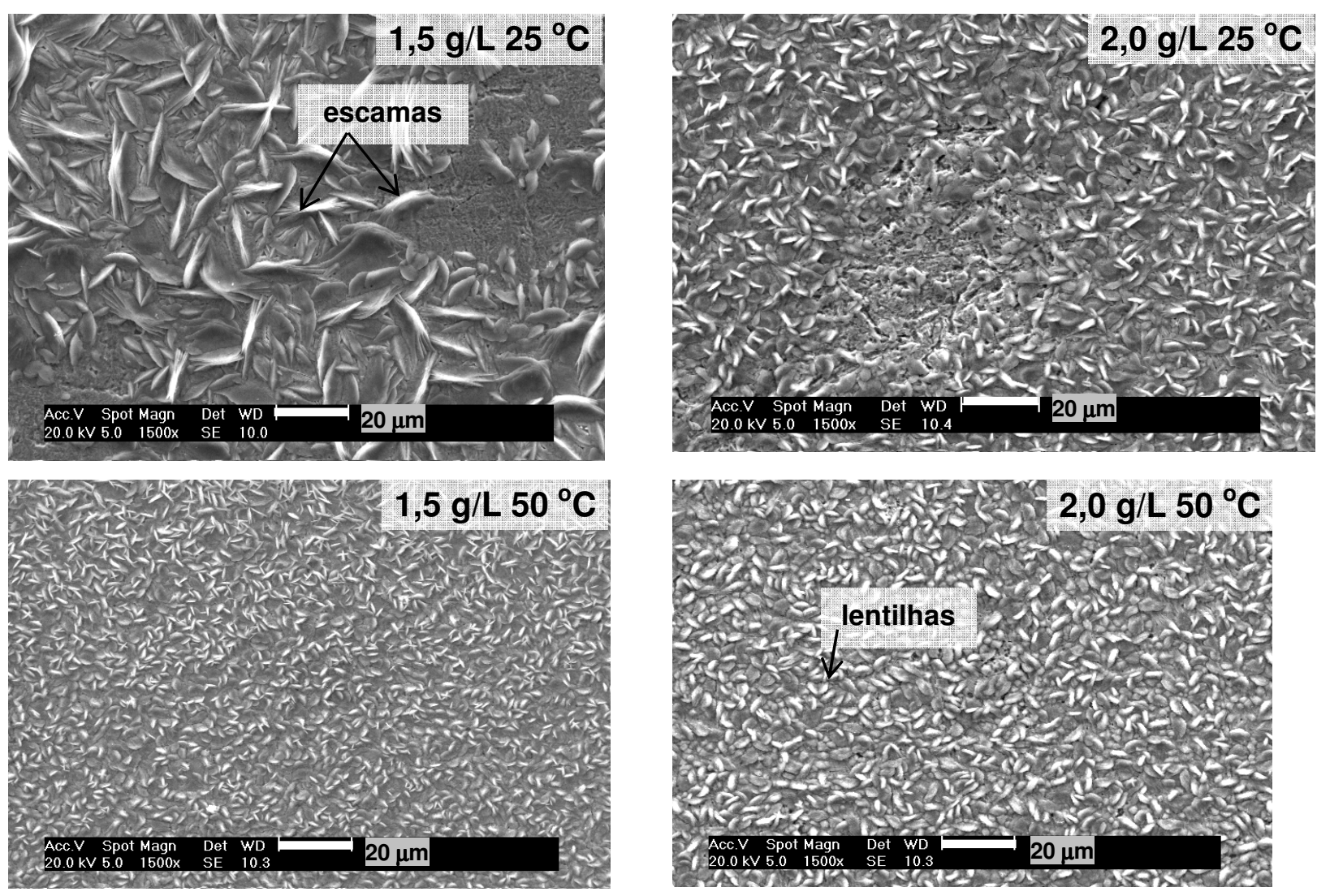

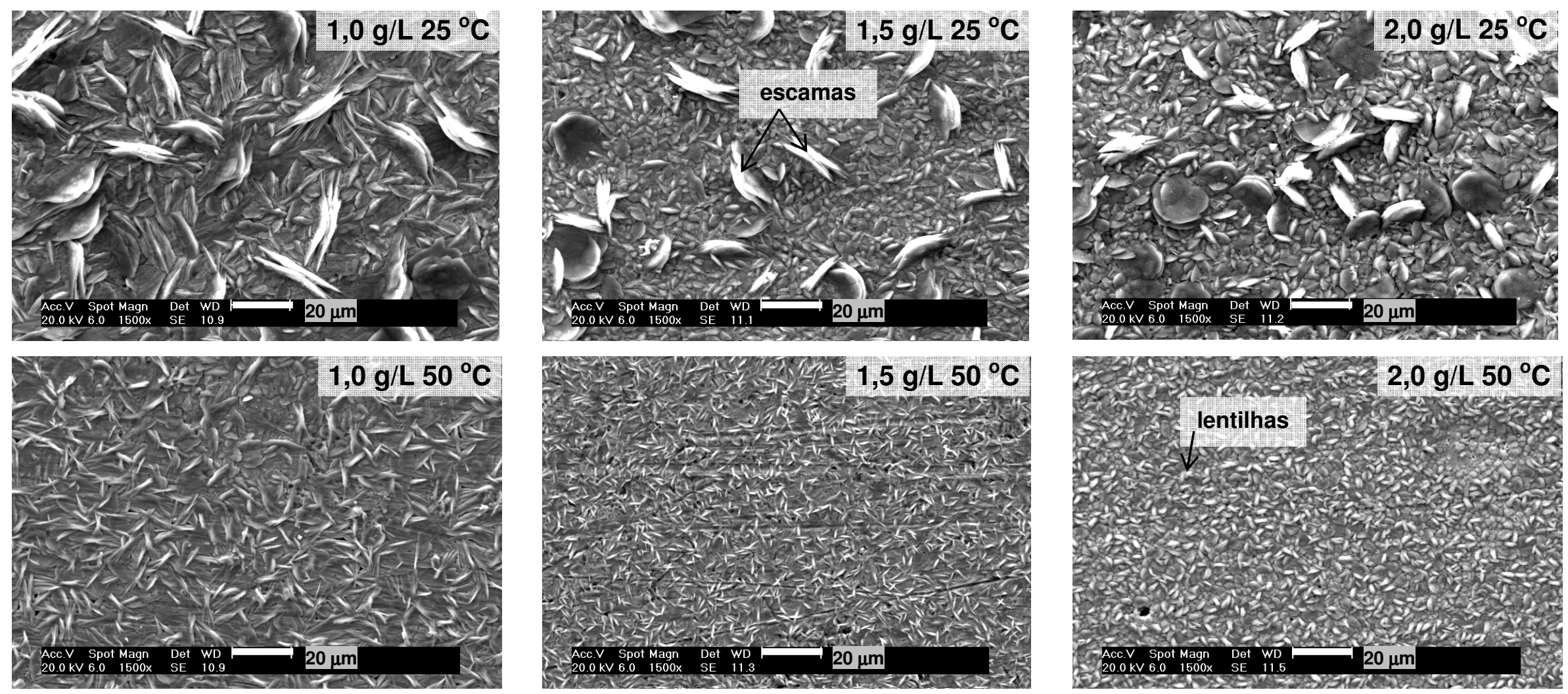

Figura 31. Camadas de fosfato de $\mathrm{Zn}$, Mn e Nb (5 mg.L $\left.\mathrm{L}^{-1}\right)$ obtidas para 5 minutos de imersão em banho de fosfato com várias concentrações de $\mathrm{NaNO}_{2}$ a $25^{\circ} \mathrm{C}$ e $50^{\circ} \mathrm{C}$. 
As micrografias da Figura 30, obtidas para o tempo de imersão de 3 minutos, mostram que o aumento da temperatura nas concentrações do acelerador de 1,0 g.L $\mathrm{L}^{-1}$ e 1,5 g. $\mathrm{L}^{-1}$, provocou redução nos tamanhos dos cristais, o que não se verificou para a concentração de 2,0 g. $\mathrm{L}^{-1}$. Também para as três concentrações, 1,0 g.L $\mathrm{L}^{-1}$ e 1,5 g. $\mathrm{L}^{-1}$ e 2,0 g. $\mathrm{L}^{-1}$ do acelerador, uma melhor cobertura foi obtida para a temperatura de $50{ }^{\circ} \mathrm{C}$ em comparação a $25{ }^{\circ} \mathrm{C}$. Pode-se observar que para $25{ }^{\circ} \mathrm{C}$ o aumento da concentração do acelerador provocou redução no tamanho dos cristais, o que é mais significativo na concentração de 2,0 g.L $\mathrm{L}^{-1}$. Já para a temperatura de $50{ }^{\circ} \mathrm{C}$ este efeito de redução do tamanho dos cristais com o aumento na concentração do acelerador não foi verificado.

Pelas micrografias da Figura 31 é possível avaliar a influência da temperatura e concentração de nitrito na morfologia e tamanho dos cristais de fosfato. Observa-se que com o aumento da concentração de acelerador de $\mathrm{NaNO}_{2}$, de 1,0 g.L $\mathrm{L}^{-1}$ para 2,0 g.L $\mathrm{L}^{-1}$, houve uma redução no tamanho dos cristais formados, e esta diminuição também ocorreu com o aumento da temperatura de $25^{\circ} \mathrm{C}$ para $50{ }^{\circ} \mathrm{C}$, o que pode ser explicado pelo favorecimento da nucleação de cristais de fosfato a partir do aumento da concentração de acelerador e da temperatura. Também nota-se que a camada formada à temperatura de $50{ }^{\circ} \mathrm{C}$ apresenta cristais mais homogêneos do que a $25{ }^{\circ} \mathrm{C}$. Porém, as camadas obtidas para $25{ }^{\circ} \mathrm{C}$ aparentemente proporcionaram melhor cobertura da superfície, não se observando os riscos do substrato que são visualizados nas camadas obtidas a $50^{\circ} \mathrm{C}$. Observa-se também uma pequena alteração na morfologia dos cristais, que tenderam a uma forma de lentilhas. 
6.1.4. Micrografias por $\mathrm{MEV}$ do efeito do tempo de imersão e da concentração de $\mathrm{NaNO}_{2}$ na morfologia da camada de fosfato de zinco, manganês e nióbio.

As Figuras 32 e 33 organizam as micrografias com relevância à influência da variação do tempo de imersão, nas camadas formadas.
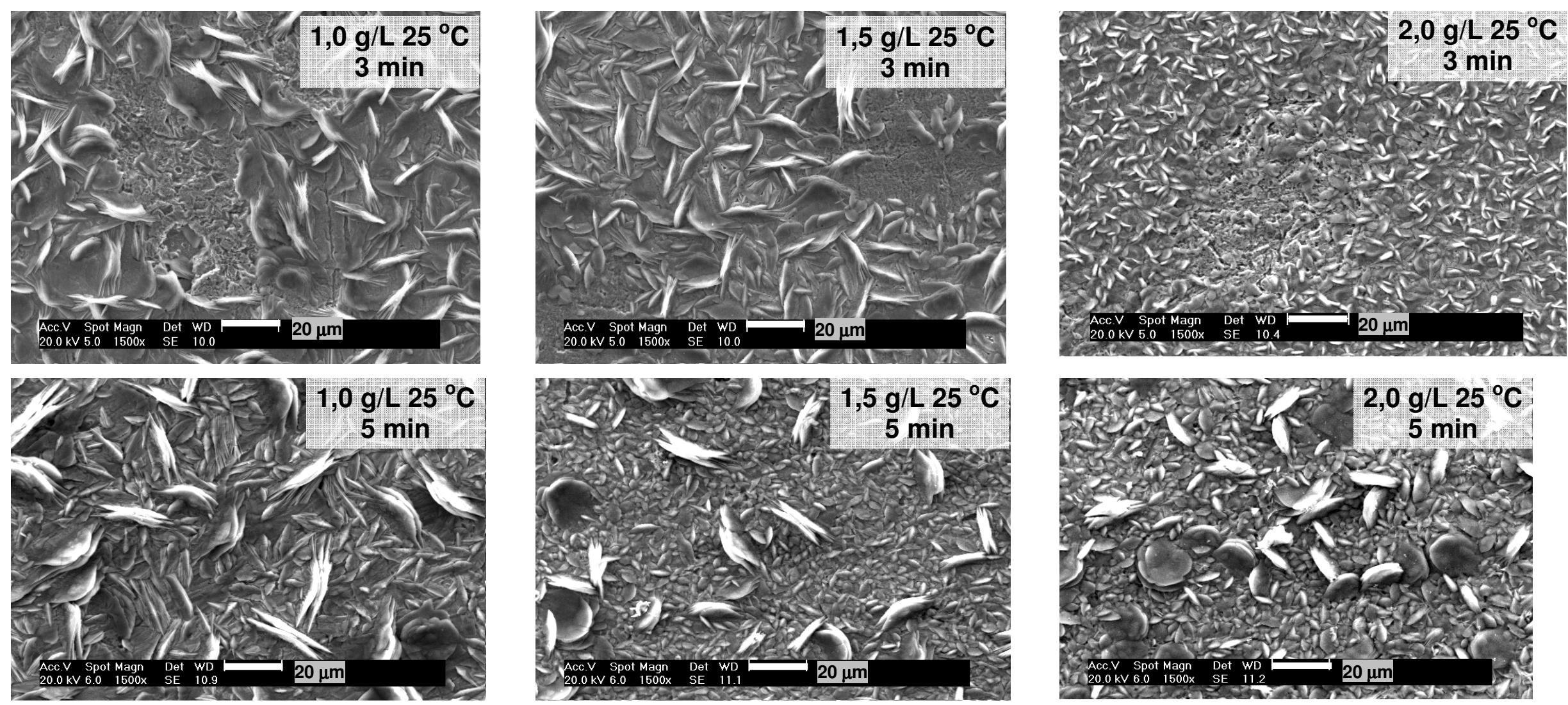

Figura 32. Superfícies do aço fosfatizado em banho de $\mathrm{Zn}, \mathrm{Mn}$ e $\mathrm{Nb}\left(5 \mathrm{mg} . \mathrm{L}^{-1}\right)$ a $25^{\circ} \mathrm{C}$ com várias concentrações de $\mathrm{NaNO}_{2}$, para 3 e 5 minutos de imersão. 

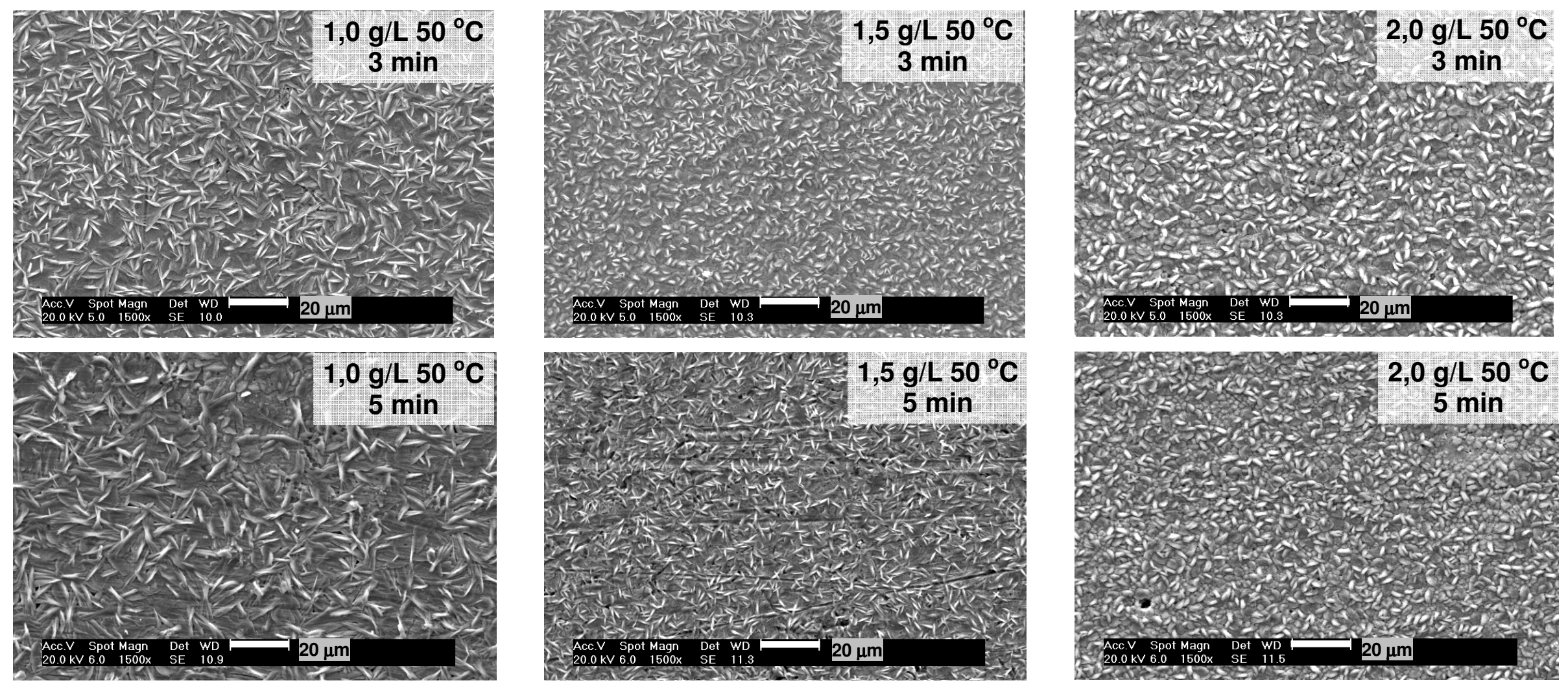

Figura 33. Superfície do aço fosfatizado em banho de $\mathrm{Zn}$, Mn e $\mathrm{Nb}\left(5 \mathrm{mg} . \mathrm{L}^{-1}\right)$ a $50{ }^{\circ} \mathrm{C}$ com várias concentrações de $\mathrm{NaNO}_{2}$, para 3 e 5 minutos de imersão. 
As micrografias da Figura 32 mostram que para uma mesma concentração de $\mathrm{NaNO}_{2}$, à mesma temperatura, o tempo de imersão de 3 minutos não proporcionou boa cobertura do substrato, o que mostra a necessidade de um tempo maior de fosfatização, como foi indicado pelo ensaio gravimétrico.

Observando a Figura 33, nota-se que o aumento no tempo de imersão para a temperatura de $50{ }^{\circ} \mathrm{C}$ não causou modificações significativas na morfologia e tamanho dos grãos, como visto para a temperatura de $25^{\circ} \mathrm{C}$.

Foram selecionadas duas condições de fosfatização para o banho contendo oxalato de nióbio e amônio, com base nas observações obtidas, a saber:

\section{1 - Banho de $\mathrm{Zn}$, Mn e $\mathrm{Nb}$ com 2 g. $\mathrm{L}^{-1}$ de $\mathrm{NaNO}_{2}$, a $25^{\circ} \mathrm{C}$, tempo de 5 minutos.}

Condição selecionada devido à boa cobertura superficial apresentada. Os cristais apresentaram morfologia na forma de "escamas", com tamanhos variados e, em maior quantidade, grãos de menor tamanho.

\section{2 - Banho de $\mathrm{Zn}, \mathrm{Mn}$ e $\mathrm{Nb}$ com 2 g. $\mathrm{L}^{-1}$ de $\mathrm{NaNO}_{2}$, a $50{ }^{\circ} \mathrm{C}$, tempo de 3 minutos.}

Condição selecionada também devido à boa cobertura do substrato e à morfologia dos cristais existentes, basicamente com formato de "lentilhas" pequenas, possibilitando uma comparação com a condição anterior.

Estas duas condições selecionadas para o banho contendo composto de nióbio foram adotadas também para o banho de fosfato de $\mathrm{Zn}$ e Mn, com fins de comparação da influência deste composto na camada de fosfato bicatiônico ( $\mathrm{Zn}$ e $\mathrm{Mn}$ ).

Além destas duas condições escolhidas para o banho com $\mathrm{Nb}$ e com $\mathrm{Zn}$ e $\mathrm{Mn}$, foram também caracterizadas amostras de aço fosfatizado com o banho tricatiônico de referência contendo níquel, e o aço sem nenhum revestimento (item 6.2). 


\subsection{Caracterização Superficial das Camadas de Fosfato Obtidas em Banhos com Base em Concentrado Laboratorial}

\subsubsection{Microscopia Eletrônica de Varredura (MEV) das Camadas de Fosfato}

A morfologia dos revestimentos de fosfato foi observada em microscópio eletrônico de varredura, sendo apresentadas a seguir as micrografias do substrato metálico e das várias camadas de fosfato obtidas.

\subsubsection{Aço Carbono sem Revestimento}

A Figura 34 apresenta micrografia da superfície do aço carbono 1005, após lixamento com papel de SiC com granulometrias \#320, \#400 e \#600, lavagem com água e álcool e secagem com ar quente.

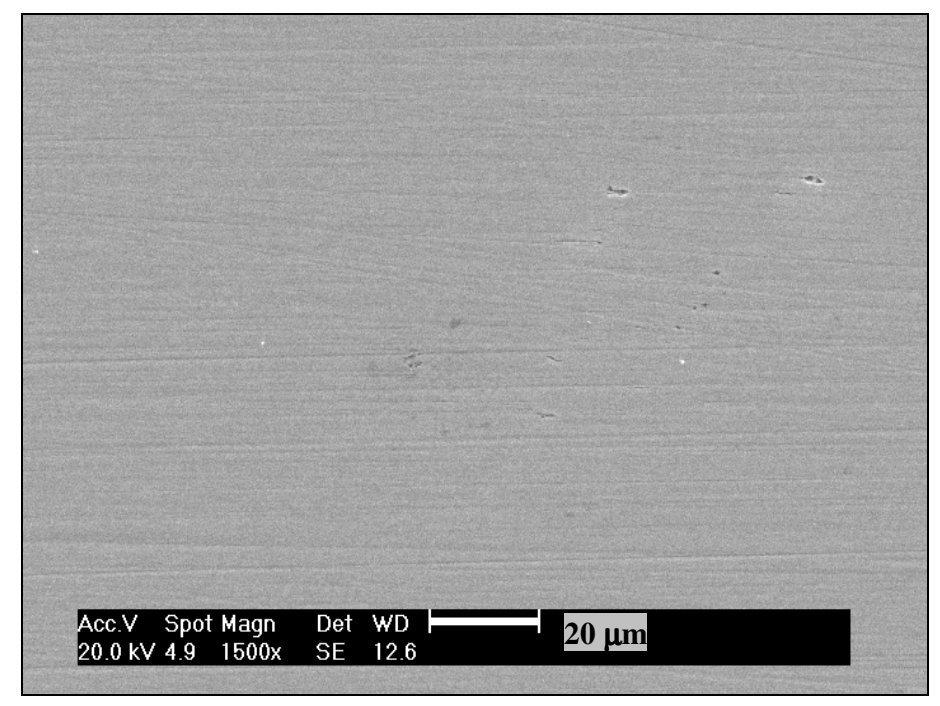

Figura 34. Micrografia obtida por MEV da superfície do aço carbono sem revestimento.

\subsubsection{Aço com Fosfato Tricatiônico de Zinco, Manganês e Níquel}

As micrografias apresentadas na Figura 35 mostram o revestimento de fosfato de zinco, manganês e níquel, obtido em banho com 0,5 g.L $\mathrm{L}^{-1}$ de $\mathrm{NaNO}_{2}$ a $25{ }^{\circ} \mathrm{C}$ por 5 minutos 
de imersão (banho padrão). As micrografias mostram cobertura relativamente homogênea do substrato por cristais finos na forma de lâminas.
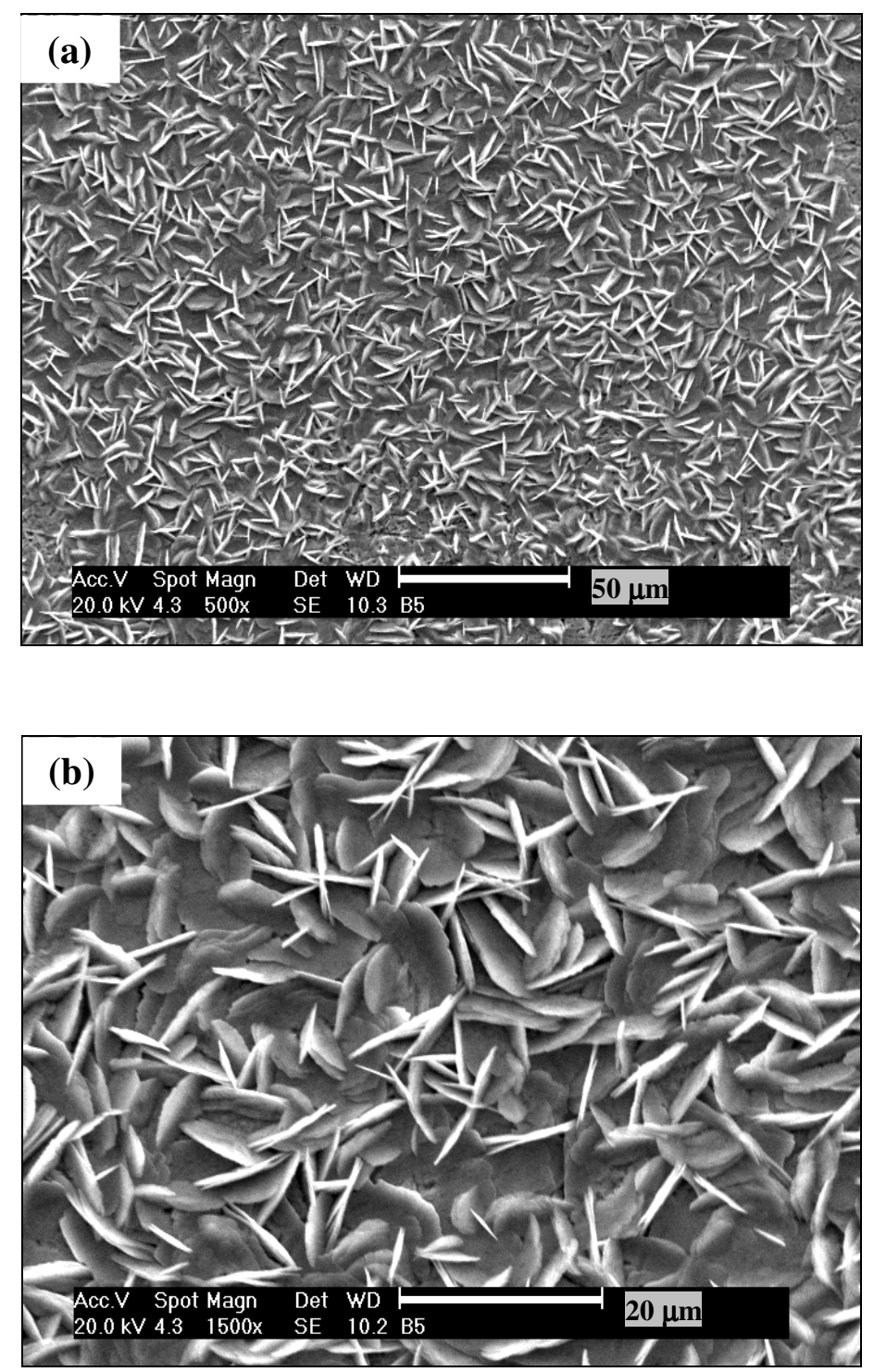

Figura 35. Micrografias por MEV de camada de fosfato tricatiônico de Zn, Mn e Ni, obtido para 5 minutos em banho com 0,5 g. $\mathrm{L}^{-1}$ de $\mathrm{NaNO}_{2}$, a $25^{\circ} \mathrm{C}$. (a) Aumento menor mostrando regiões de baixa cobertura do substrato e (b) maior aumento mostrando a morfologia dos cristais. 
6.2.1.3. Aço com Fosfato Tricatiônico de Zinco, Manganês e Nióbio

As micrografias apresentadas pelas Figuras 36 e 37 mostram os revestimentos de fosfato de zinco, manganês e nióbio obtidos em banhos com 2,0 g. $\mathrm{L}^{-1}$ de $\mathrm{NaNO}_{2}$ nas temperaturas de $25^{\circ} \mathrm{C}$ por 5 minutos e $50^{\circ} \mathrm{C}$ por 3 minutos de imersão.
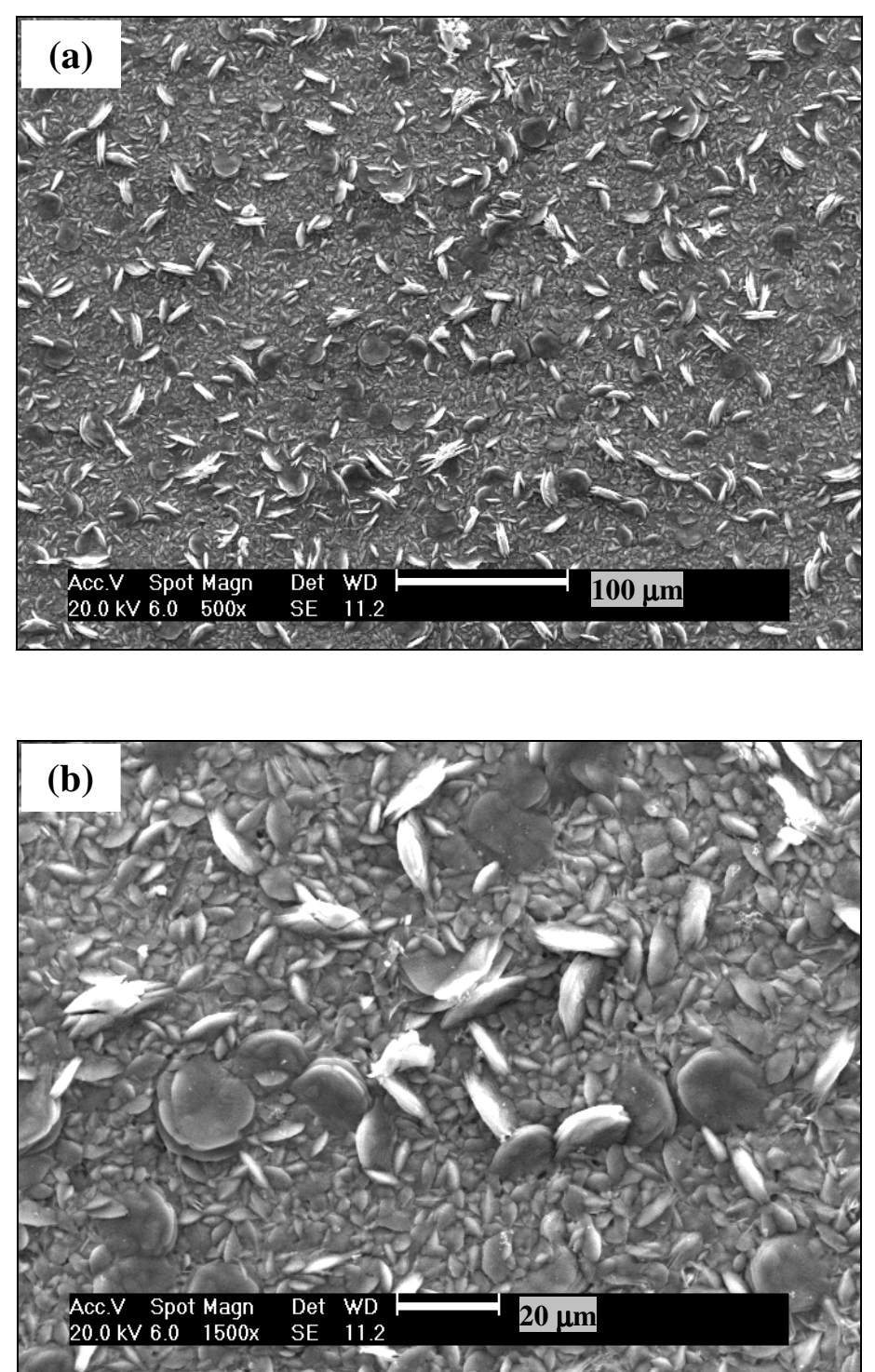

Figura 36 (a) e (b). Micrografias por MEV de camada de fosfato tricatiônico de Zn, Mn e Nb, obtido para 5 minutos em banho com 2,0 g. $\mathrm{L}^{-1}$ de $\mathrm{NaNO}_{2}$, a $25{ }^{\circ} \mathrm{C}$. 

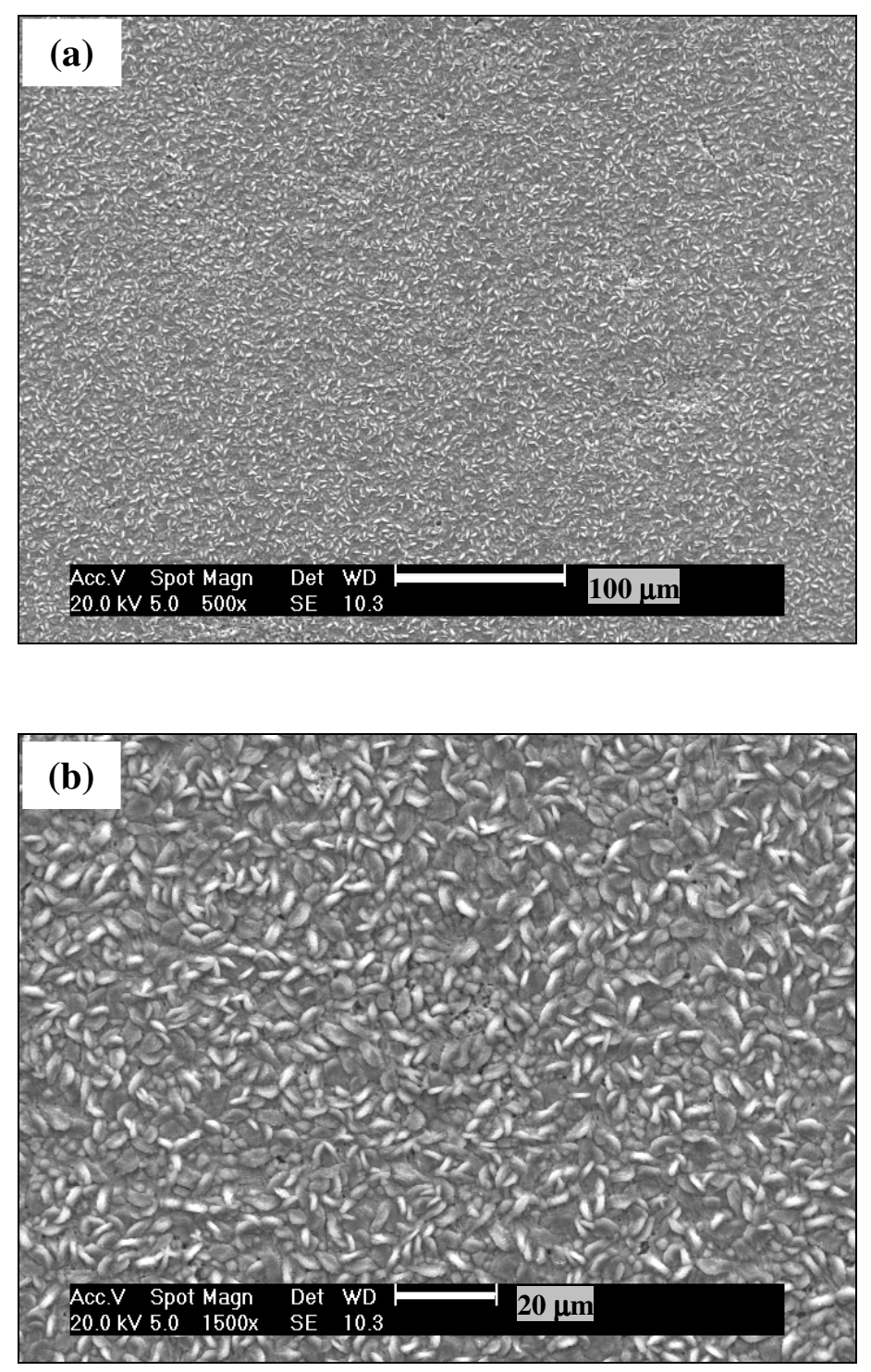

Figura 37 (a) e (b). Micrografias por MEV de camada de fosfato tricatiônico de Zn, Mn e Nb, obtido para 3 minutos em banho com 2,0 g. $\mathrm{L}^{-1}$ de $\mathrm{NaNO}_{2}$, a $50{ }^{\circ} \mathrm{C}$.

As duas condições de fosfatização no banho com composto de nióbio produziram camadas com morfologia de cristais bem diferentes, porém, boa cobertura em ambas as condições. A camada formada para tempo de imersão de 5 minutos a $25^{\circ} \mathrm{C}$ é composta por cristais de tamanhos bem diferentes, os maiores com formato de "escamas" irregulares e, em geral, maiores do que o dos cristais da camada obtida para 3 minutos de imersão a 50 ${ }^{\circ} \mathrm{C}$. As micrografias das Figuras 36 e 37 mostram uma cobertura relativamente homogênea do substrato pelos cristais de fosfato. A presença de cristais com formatos irregulares, como o da Figura 36, pode contribuir para uma boa aderência a revestimentos orgânicos. 
O aumento da temperatura parece ter contribuído para uma diminuição no tamanho dos cristais e maior homogeneização dos mesmos. Isto pode ser causado pelo favorecimento da nucleação com o aumento da temperatura, o que resulta em cristais de menor tamanho.

A morfologia dos cristais encontrada nas camadas de fosfato com $\mathrm{Zn}, \mathrm{Mn}$ e $\mathrm{Nb}$ é bem distinta daquela observada em camadas de fosfato compostas por $\mathrm{Zn}, \mathrm{Mn}$ e Ni. A troca do níquel pelo composto de nióbio provoca, portanto, a mudança na morfologia dos cristais, da forma de lâminas, característica do fosfato tricatiônico com Ni, para a forma de “escamas" ou "lentilhas", para camadas sem a presença do Ni.

\subsubsection{Aço com Fosfato de Zinco e Manganês}

Camadas de fosfato compostas somente por Zn e Mn foram também observadas por MEV para as mesmas condições de fosfatização usadas para o fosfato tricatiônico com composto de nióbio. As Figuras 38 e 39 apresentam micrografias destas camadas.

Os cristais nas camadas de fosfato de zinco e manganês apresentaram forma mais lamelar que os encontrados na presença de $\mathrm{Nb}$, sendo que o aumento da temperatura proporcionou um aumento no tamanho dos cristais, ao contrário do que se verificou nas camadas de fosfato de zinco, manganês e nióbio. Estes resultados sugerem que o nióbio favorece a nucleação (formação de novos núcleos), enquanto que na ausência de nióbio, o aumento da temperatura favorece o crescimento dos cristais.

As micrografias apresentadas mostram que o composto de nióbio acrescido ao banho de fosfato de $\mathrm{Zn}$ e $\mathrm{Mn}$, altera significativamente a morfologia dos cristais bem como o tamanho destes. 

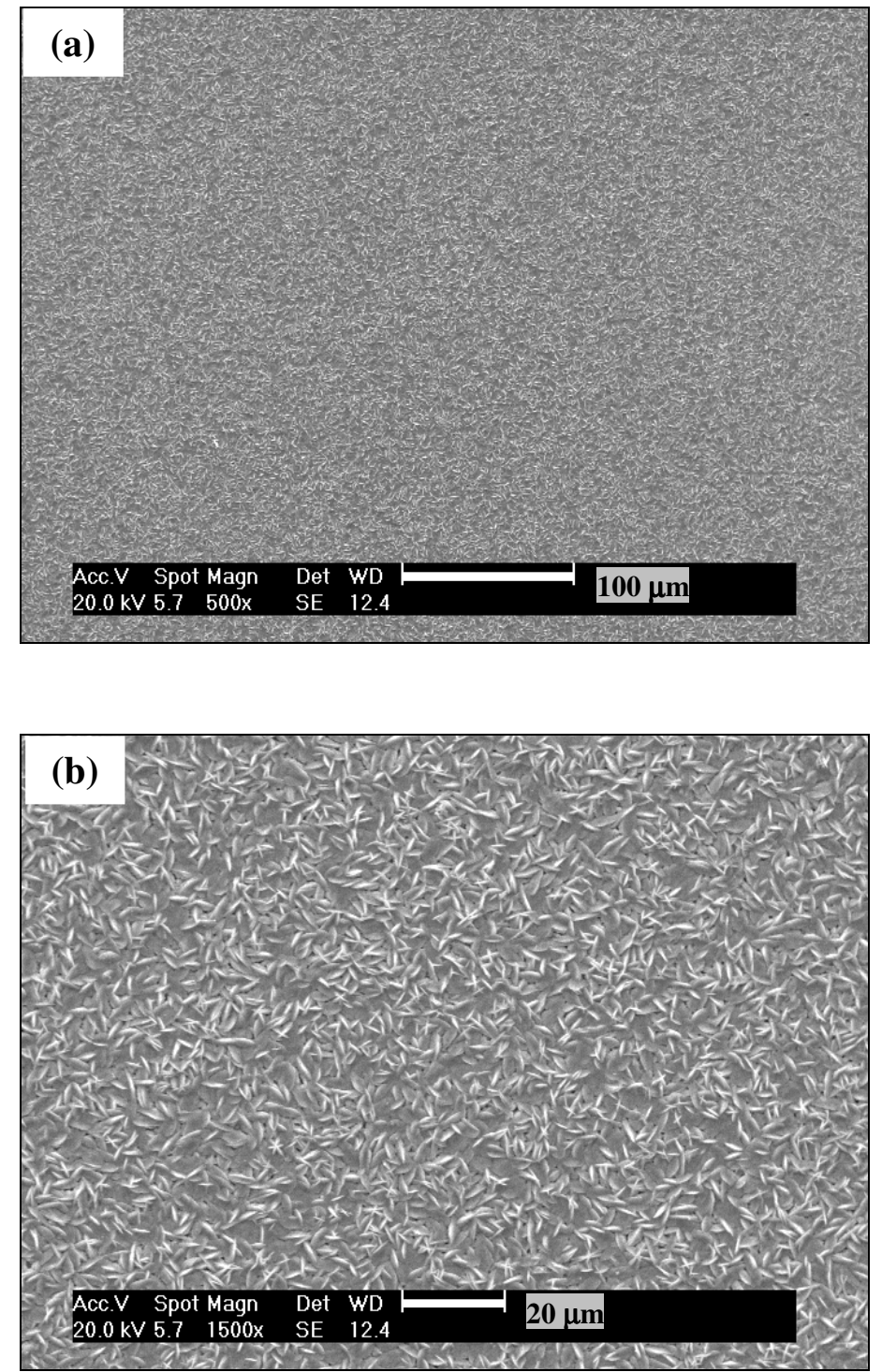

Figura 38 (a) e (b). Micrografias por MEV de camada de fosfato de Zn e Mn obtida para 5 minutos de imersão em banho com 2,0 g. $\mathrm{L}^{-1}$ de $\mathrm{NaNO}_{2}$, a $25^{\circ} \mathrm{C}$. 

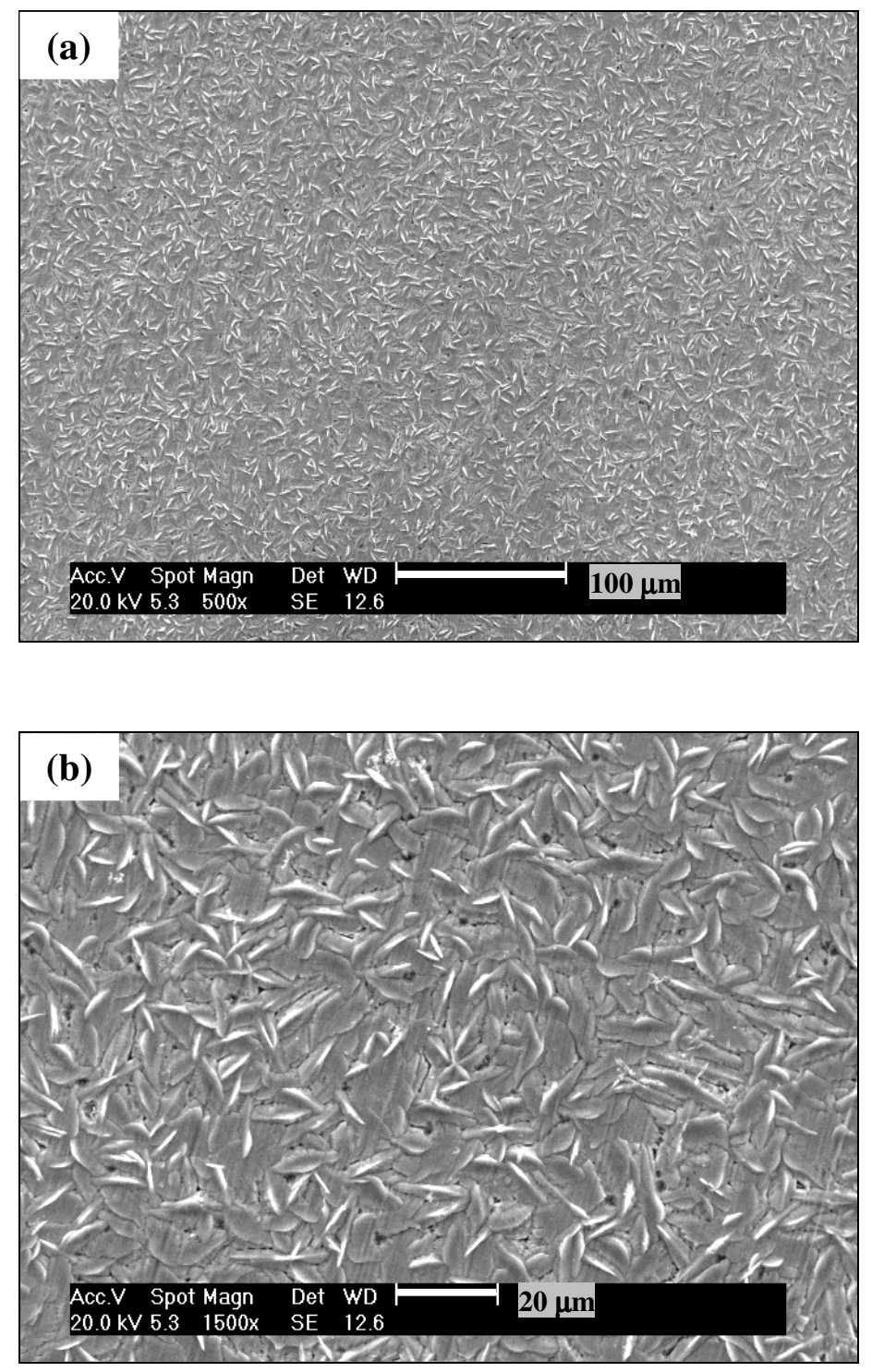

Figura 39 (a) e (b). Micrografias por MEV de camada de fosfato de Zn e Mn obtida para 3 minutos de imersão em banho com 2,0 g. $\mathrm{L}^{-1}$ de $\mathrm{NaNO}_{2}$, a $50{ }^{\circ} \mathrm{C}$.

\subsubsection{Determinação da Composição Química Elementar das Camadas de Fosfato}

A caracterização das camadas de fosfato foi também realizada por espectroscopia de energia dispersiva, espectroscopia por infravermelho e difração de raios-X. 


\subsubsection{Espectroscopia de Energia Dispersiva (EDS)}

A caracterização química das camadas obtidas foi realizada por espectroscopia de energia dispersiva acoplada a microscópio eletrônico de varredura (marca Philips modelo XL - 30), no Laboratório de Microscopia Eletrônica e de Força Atômica, do Departamento de Engenharia Metalúrgica e de Materiais, EPUSP. Na Figura 40 são apresentados espectros obtidos de amostras de aço fosfatizadas, e sem revestimento.

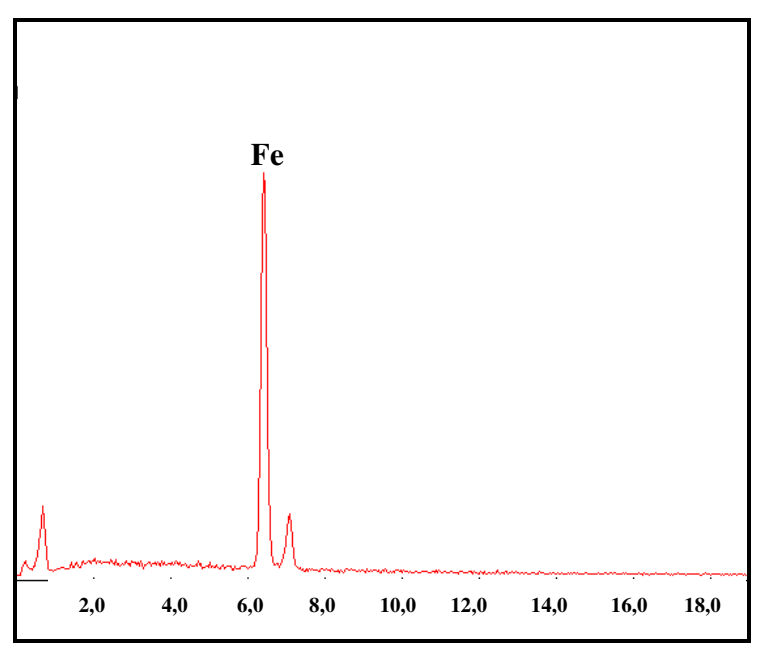

(a) Sem revestimento

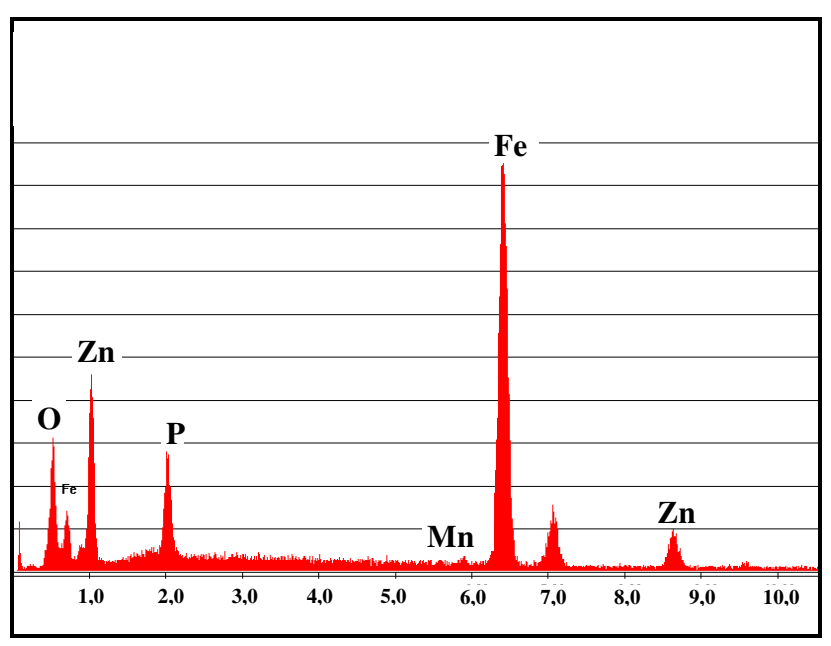

(b) Fosfato de Zn, Mn, Ni obtido a $25{ }^{\circ} \mathrm{C}$ por 5 min, com 0,5g.L $\mathrm{L}^{-1}$ de $\mathrm{NaNO}_{2}$

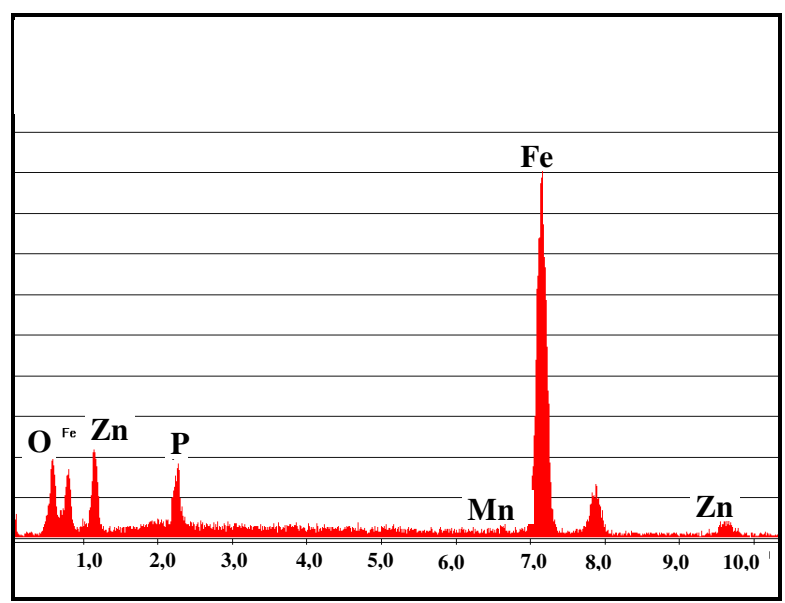

(d) Fosfato de Zn, Mn, Nb obtido a 50 ${ }^{\circ} \mathrm{C}$ por 3 min, com 2 g. $\mathrm{L}^{-1}$ de $\mathrm{NaNO}_{2}$ por 5 min, com 2 g.L $\mathrm{L}^{-1}$ de $\mathrm{NaNO}_{2}$ 


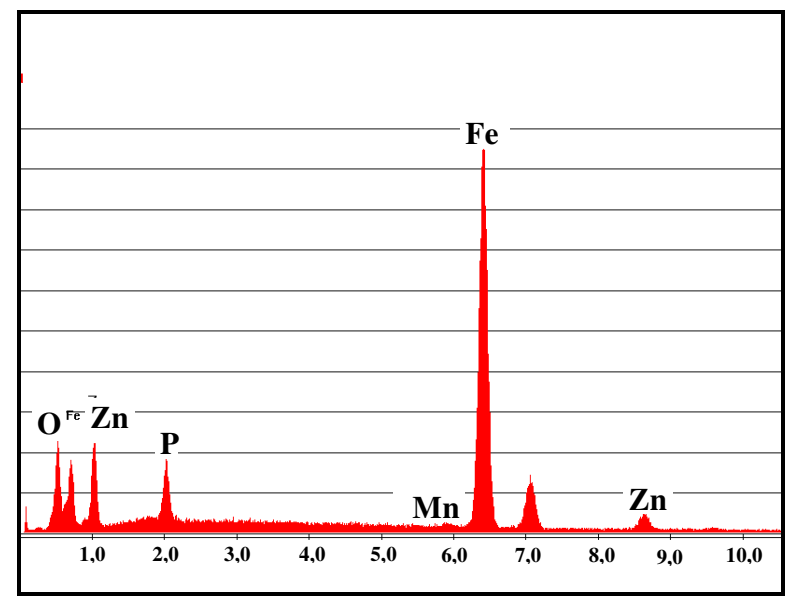

(e) Fosfato de Zn, Mn obtido a $25^{\circ} \mathrm{C}$ por 5 min, com 2g. $\mathrm{L}^{-1}$ de $\mathrm{NaNO}_{2}$

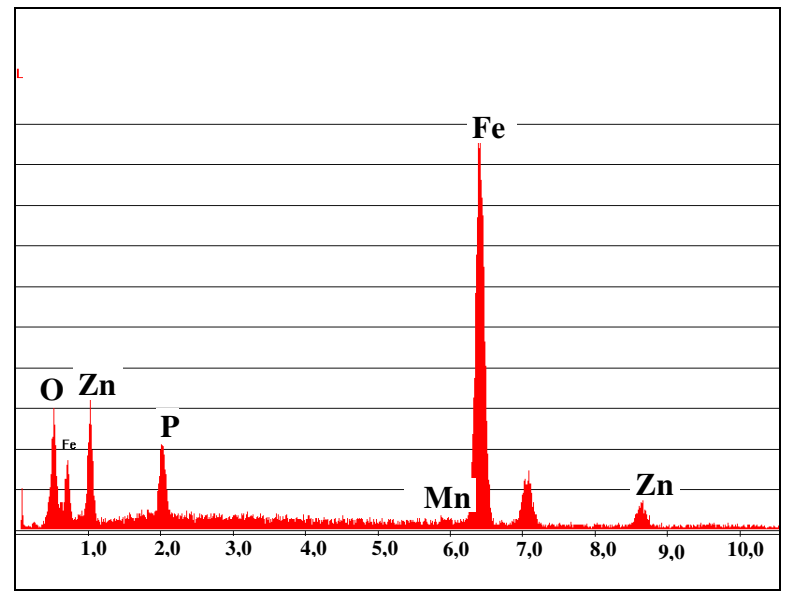

(f) Fosfato de Zn, Mn obtido a $50{ }^{\circ} \mathrm{C}$ por 3 min, com 2 g. $\mathrm{L}^{-1}$ de $\mathrm{NaNO}_{2}$

\section{Figura 40 (a) - (f). Espectros obtidos por EDS da superfície do aço carbono, sem e com vários tipos de camadas de fosfato.}

Os espectros apresentados na Figura 40 mostram picos relacionados aos elementos: Oxigênio (O), Zinco (Zn), Fósforo (P), Manganês (Mn) e Ferro (Fe) da camada de fosfato. Isto foi observado para todas as camadas de fosfato obtidas, sendo que o níquel (Ni) e o nióbio $(\mathrm{Nb})$ que também estavam na composição dos banhos de fosfatização, não foram observados em nenhum espectro. O nióbio e o níquel não foram identificados provavelmente devido às quantidades muito baixas destes adicionadas aos banhos.

Não foram observadas diferenças significativas entre as quantidades dos elementos nas camadas de fosfato de $\mathrm{Zn}$ e $\mathrm{Mn}$, ainda que tenham existido diferenças no tempo de imersão, temperatura e concentração do acelerador. Esta diferença é bem mais relevante entre as camadas do fosfato tricatiônico com composto de nióbio, em que maiores quantidades de zinco e fósforo foram obtidas para o fosfato de $\mathrm{Zn}, \mathrm{Mn}$ e $\mathrm{Nb}$ a $25^{\circ} \mathrm{C}$ por 5 min, com 2 g.L.-1 de $\mathrm{NaNO}_{2}$ (Figura 40 (c)). 


\subsubsection{Espectroscopia por Infravermelho}

As Figuras 41 e 42 apresentam uma comparação entre os espectros obtidos para as camadas de fosfato de $\mathrm{Zn}, \mathrm{Mn}$ e $\mathrm{Ni}$, em relação às camadas de fosfato de $\mathrm{Zn}, \mathrm{Mn}, \mathrm{Nb}$ e de Zn e Mn, nos tempos de 3 e 5 minutos de imersão destas últimas.

Pode-se observar que em todos os casos os espectros obtidos têm a mesma configuração. Os picos ocorrem nos mesmos intervalos de número de onda, o que mostra que a troca do níquel pelo composto de nióbio não altera os espectros. Na Figura 42 observa-se uma diferença de massa nas camadas, sendo a camada com composto de nióbio a de maior massa.

A configuração do espectro apresentada é a mesma encontrada em referência bibliográfica para o fosfato tricatiônico [79]. As diferenças encontradas nos valores de \% de transmitância, representam diferenças no valor de massa por área das camadas, sendo que os valores menores (eixo dos Y) indicam quantidades maiores de massa [79]. A Figura 42 mostra que o maior valor de massa por área foi relacionado com a camada de fosfato de $\mathrm{Zn}, \mathrm{Mn}$ e $\mathrm{Nb}$, com 2 g. $\mathrm{L}^{-1}$ de $\mathrm{NaNO}_{2}$, por 5 minutos de imersão a $25^{\circ} \mathrm{C}$, seguida da camada de fosfato de $\mathrm{Zn}, \mathrm{Mn}$ e Ni, e da camada de fosfato de $\mathrm{Zn}$ e Mn.

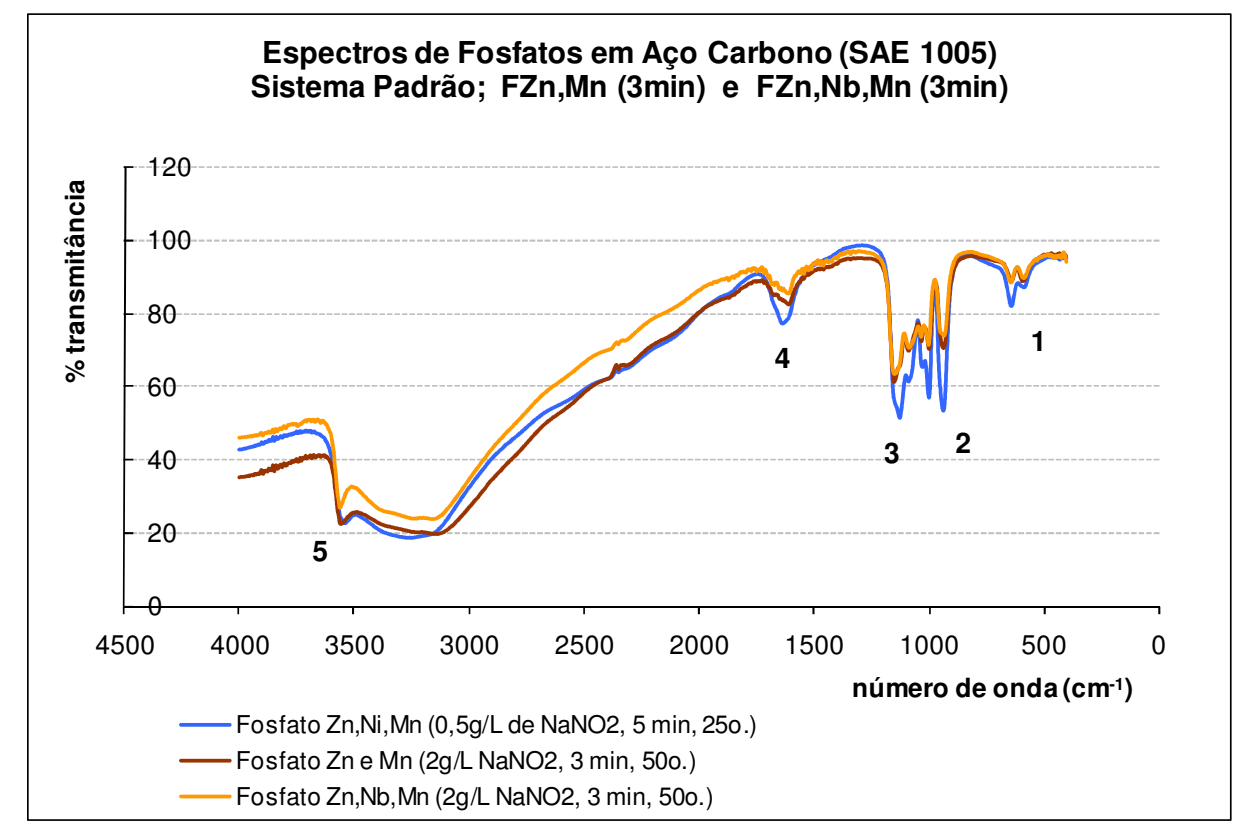

Figura 41. Espectros de infravermelho das camadas de fosfato de $\mathrm{Zn}$, Mn e Ni; Zn, Mn, Nb e Zn, Mn, obtidas para diferentes condições de temperatura e tempo de imersão. 


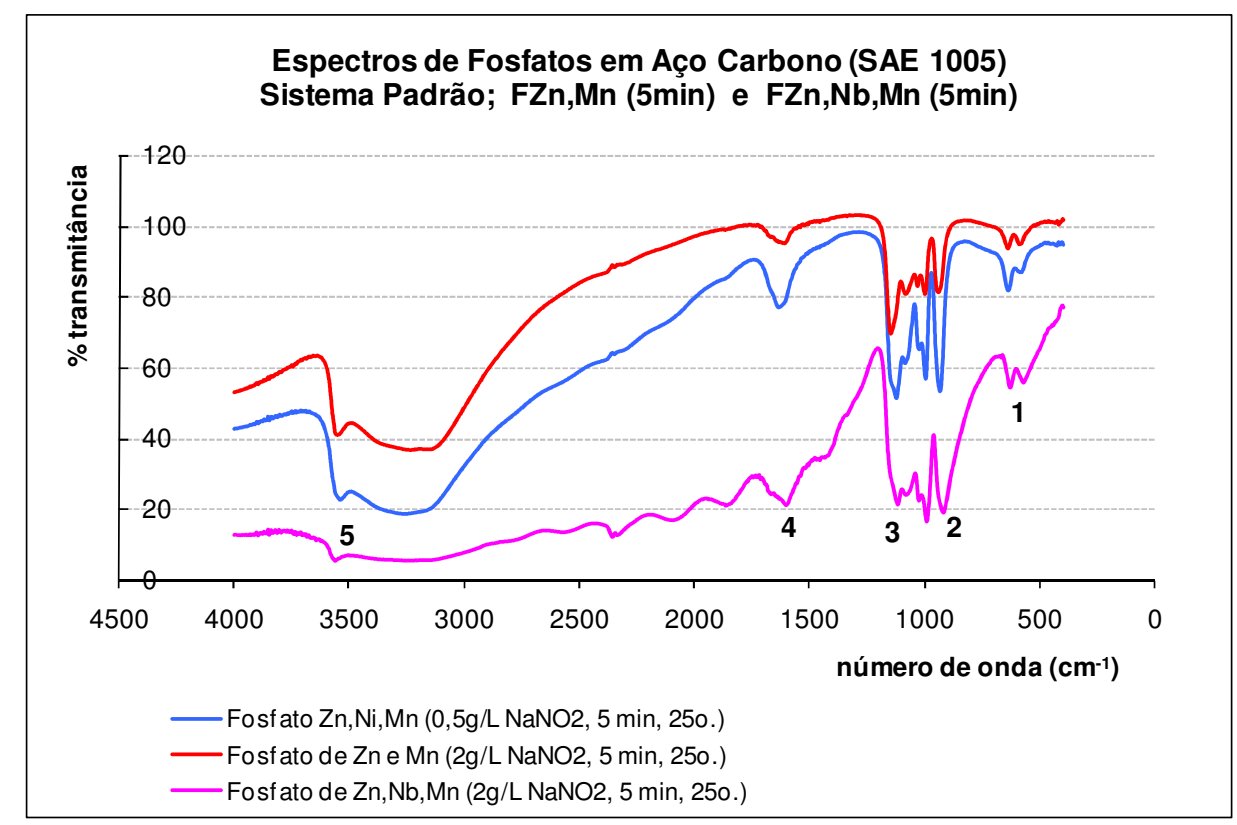

Figura 42. Espectros de infravermelho das camadas de fosfato de $\mathrm{Zn}$, Mn e Ni em relação às camadas de $\mathrm{Zn}, \mathrm{Mn}, \mathrm{Nb}$ e de $\mathrm{Zn}, \mathrm{Mn}$ à $25^{\circ} \mathrm{C}$ por 5 minutos de imersão.

A Tabela 20 apresenta as faixas de absorção características para os picos encontrados nos gráficos das Figuras 41 e 42 [19, 39].

Tabela 20. Absorções características no IR para camadas obtidas de fosfato tricatiônico.

\begin{tabular}{l|l|l}
\hline $\begin{array}{l}\text { Faixa de absorção } \\
\text { característica }\left(\mathbf{c m}^{-1}\right)\end{array}$ & Atribuição & $\begin{array}{l}\mathbf{N}^{\mathbf{0}} \text { dos } \\
\text { picos }\end{array}$ \\
\hline $640 \mathrm{~cm}^{-1}$ & Vibrações devido ao grupo $\mathrm{PO}_{4}^{-3}(\mathrm{~V})^{23}$ & 1 \\
\hline $900-1200 \mathrm{~cm}^{-1}$ & Vibrações devido ao grupo $\mathrm{PO}_{4}^{-3}(\mathrm{v})$ & 2 a 3 \\
\hline $1640 \mathrm{~cm}^{-1}$ & Deformação do H-O-H em água & 4 \\
\hline 3000 a $3500 \mathrm{~cm}^{-1}$ & Vibração do estiramento O-H em água & 5 \\
\hline
\end{tabular}

${ }^{23}$ A frequência da vibração varia de acordo com o tipo de vibração molecular. Podendo ocorrer movimentos de alongamento e flexão, simétricos ou não, para dentro ou fora do plano em questão. (http://www.chem.umn.edu/groups/hoye/teaching/Teaching2312Fall2011/IR_Theory_from_CU_Boulder_sit e.pdf). 


\subsubsection{Difração de Raios X}

A análise por difração de raios-X foi realizada no Laboratório de Caracterização Tecnológica do Departamento de Engenharia de Minas e de Petróleo da Escola Politécnica da USP. A Figura 43 apresenta os resultados deste tipo de analise.
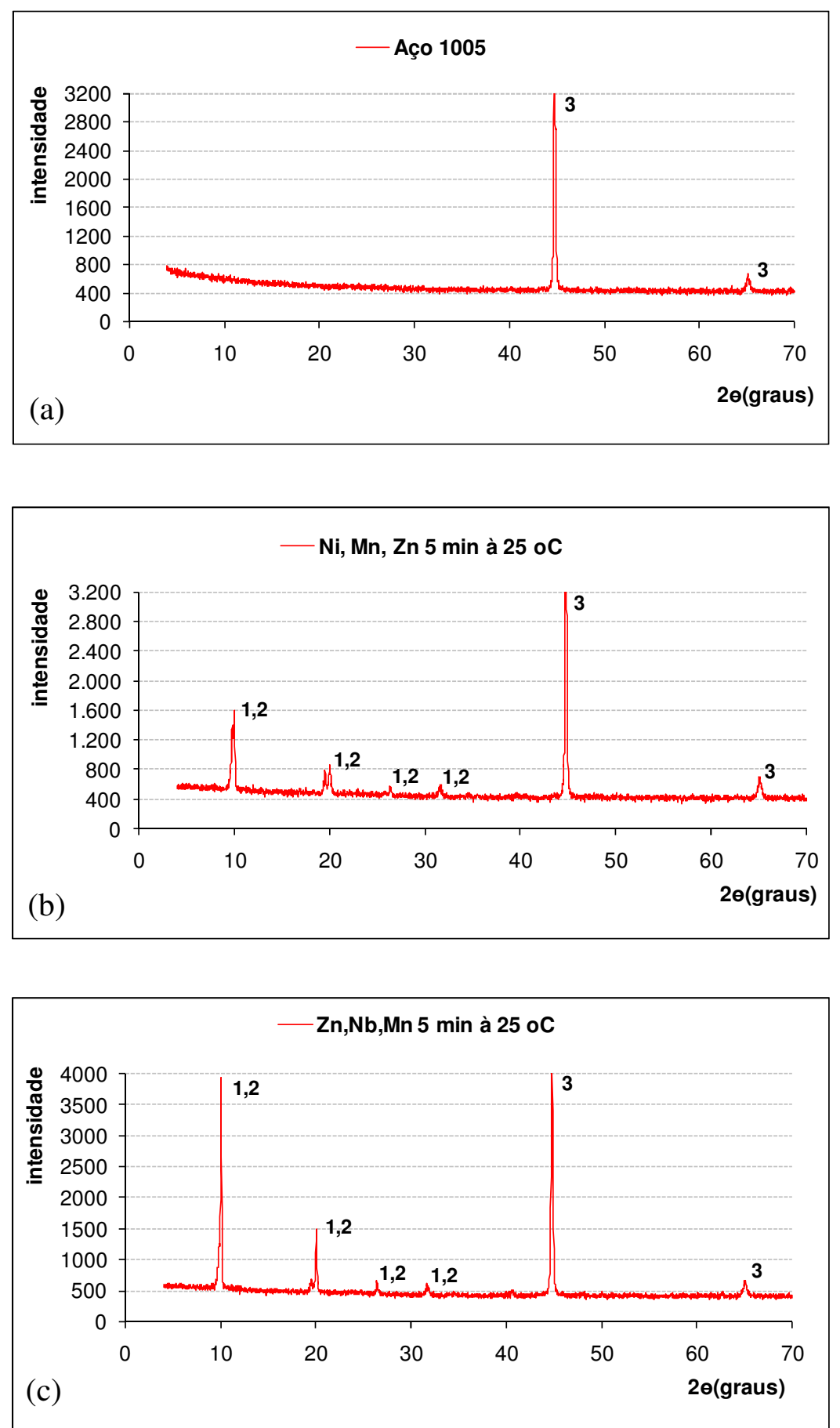


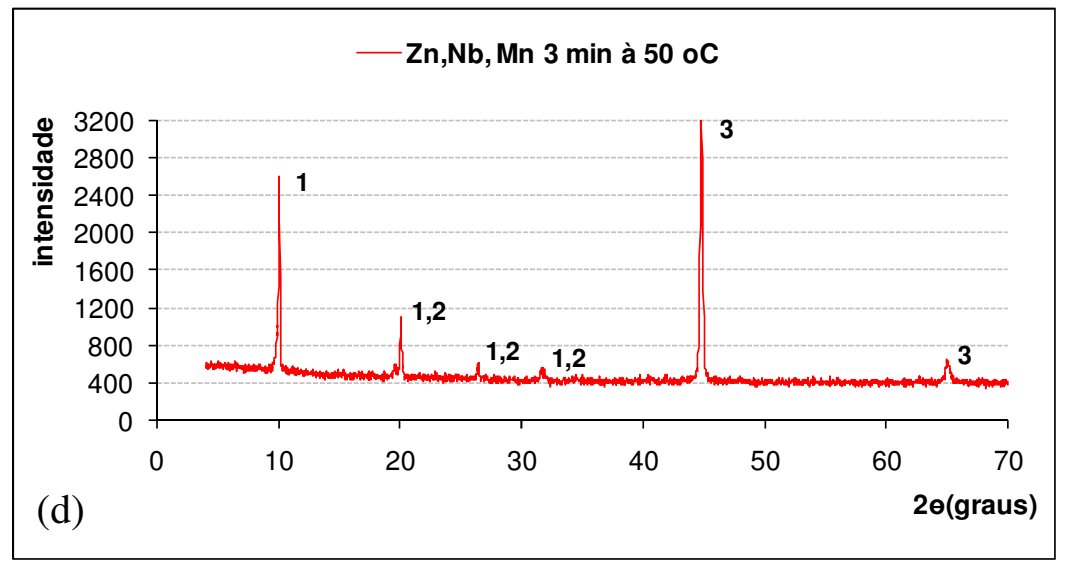

Figura 43 (a) - (d). Difratogramas de raios-X do aço carbono sem revestimento e com camadas distintas de fosfato. (1) $\mathrm{Zn}_{2} \mathrm{Fe}\left(\mathrm{PO}_{4}\right)_{2}\left(\mathrm{H}_{2} \mathrm{O}\right)_{4}$ (fosfofilita); (2) $\mathrm{Zn}_{3}\left(\mathrm{PO}_{4}\right)_{2}\left(\mathrm{H}_{2} \mathrm{O}\right)_{4}$ (hopeita); (3) Fe (ferro).

Foram identificadas 3 fases: $\mathrm{Zn}_{3}\left(\mathrm{PO}_{4}\right)_{2}\left(\mathrm{H}_{2} \mathrm{O}\right)_{4}$ (hopeite) ficha 70-1907; $\mathrm{Zn}_{2} \mathrm{Fe}\left(\mathrm{PO}_{4}\right)_{2}\left(\mathrm{H}_{2} \mathrm{O}\right)_{4}$ (phosphophyllite) ficha 76-0743 e Fe (iron) ficha 87-0722. A hopeita aparece bem próxima a fosfofilita, porém sempre em menor quantidade. Depois do ferro, a fase encontrada em maior proporção refere-se à fosfofilita (CHEEVER ${ }^{24}$ apud GENTIL) [9]. Em tratamentos de fosfatização realizados por imersão a proporção de fosfofilita tende a ser maior. Esta é quantitativamente maior no fosfato de $\mathrm{Zn}, \mathrm{Mn}$ e $\mathrm{Nb}$, obtido por 5 minutos a $25^{\circ} \mathrm{C}$ em banho com 2 g.L $\mathrm{L}^{-1}$ de $\mathrm{NaNO}_{2}$.

A identificação das fases cristalinas foi realizada com auxílio do software High Score Plus, por comparação do difratograma da amostra com os bancos de dados PDF2 do ICDD - International Centre for Diffraction Data (2003) e PAN-ICSD - PANalytical Inorganic Crystal Structure Database (2007).

${ }^{24}$ CHEEVER, G. D. Journal of Paint Technology, 39, 504 (1967). 


\subsection{Avaliação Eletroquímica da Resistência à Corrosão de Aços com Tratamentos Selecionados de Fosfatização.}

As amostras com camadas de fosfato obtidas nas condições de fosfatização selecionadas ( 3 minutos, $50{ }^{\circ} \mathrm{C}$ e 5 minutos, $25^{\circ} \mathrm{C}$ ) em banho contendo $5 \mathrm{mg} . \mathrm{L}^{-1}$ composto de nióbio foram ensaiadas por métodos eletroquímicos. Para efeito de comparação, foram também ensaiadas amostras com o fosfato de $\mathrm{Zn}, \mathrm{Mn}$, Ni e o aço 1005 sem revestimento. A Tabela 21 abaixo apresenta as condições adotadas para obtenção das camadas de fosfato avaliadas por métodos eletroquímicos.

Tabela 21. Definição dos sistemas eletroquímicos analisados.

\begin{tabular}{c|c|c|c|c}
\hline Amostra & $\begin{array}{c}\text { Tempo de } \\
\text { imersão }\end{array}$ & $\begin{array}{c}\text { Temperatura } \\
\text { do banho de } \\
\text { fosfato }\end{array}$ & $\begin{array}{c}\text { Concentração } \\
\text { do acelerador } \\
\text { (NaNO }\end{array}$ & Passivador \\
\hline Aço carbono & ---- & ---- & ----- & ---- \\
\hline $\begin{array}{c}\text { Aço com fosfato } \\
\text { Ftric } \mathrm{Zn}, \mathrm{Mn}, \mathrm{Ni}\end{array}$ & 5 minutos & $25^{\circ} \mathrm{C}$ & $0,5 \mathrm{~g} . \mathrm{L}^{-1}$ & $\mathrm{CrO}_{3}$ \\
\hline $\begin{array}{c}\text { Aço com fosfato } \\
\text { Ftric } \mathrm{Zn}, \mathrm{Mn}+\mathrm{Nb}\end{array}$ & 5 minutos & $25^{\circ} \mathrm{C}$ & $2 \mathrm{~g} . \mathrm{L}^{-1}$ & $\mathrm{CrO}_{3}$ \\
\hline $\begin{array}{l}\text { Aço com fosfato } \\
\text { Ftric } \mathrm{Zn}, \mathrm{Mn}+\mathrm{Nb}\end{array}$ & 3 minutos & $50^{\circ} \mathrm{C}$ & $2 \mathrm{~g} . \mathrm{L}^{-1}$ & $\mathrm{CrO}_{3}$ \\
\hline
\end{tabular}

\subsubsection{Espectroscopia de Impedância Eletroquímica (EIE) de Aços Fosfatizados}

Os ensaios de espectroscopia de impedância foram realizados após 2 horas de imersão na solução de ensaio de corrosão. As Figuras 44 e 45 apresentam os diagramas de Nyquist e de ângulo de fase de Bode para o aço sem revestimento e para amostras fosfatizadas e passivadas com $\mathrm{CrO}_{3}$. 


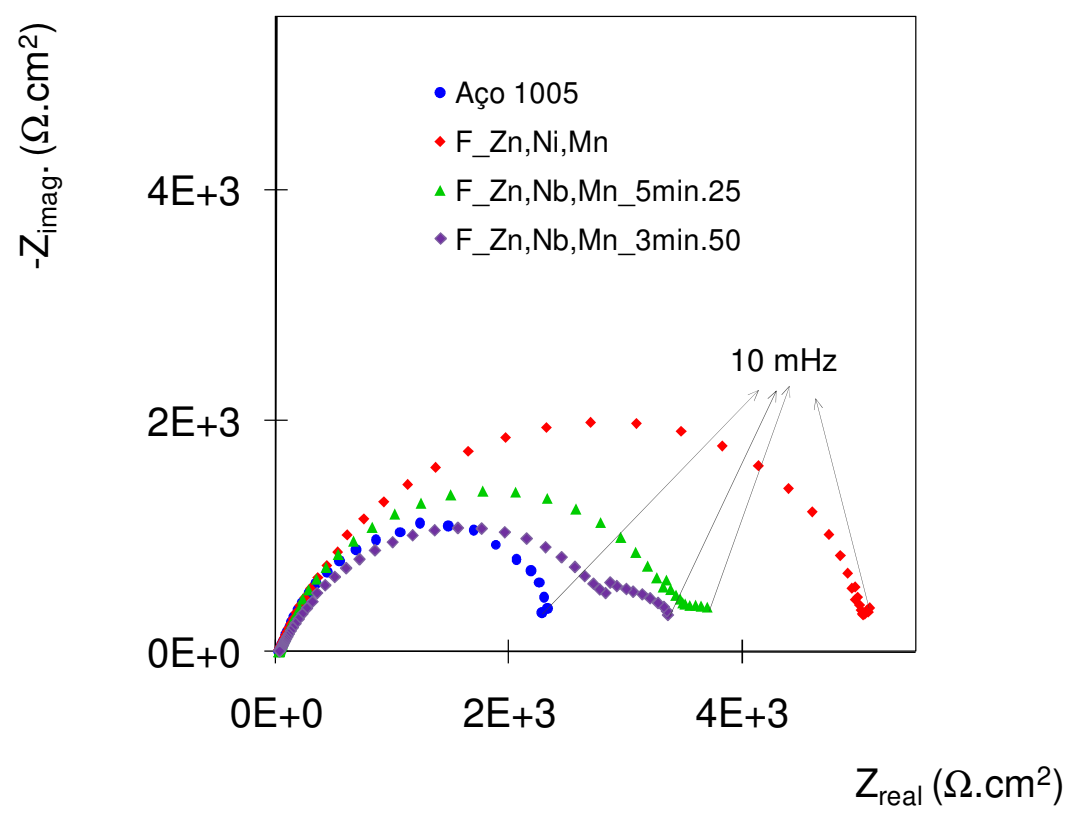

Figura 44. Diagramas de Nyquist para amostras de aço carbono $1005 \mathrm{sem}$ revestimento e revestidas com fosfatos tricatiônicos, ensaiadas em solução de 0,5 mol.L ${ }^{-1}$ de NaCl.

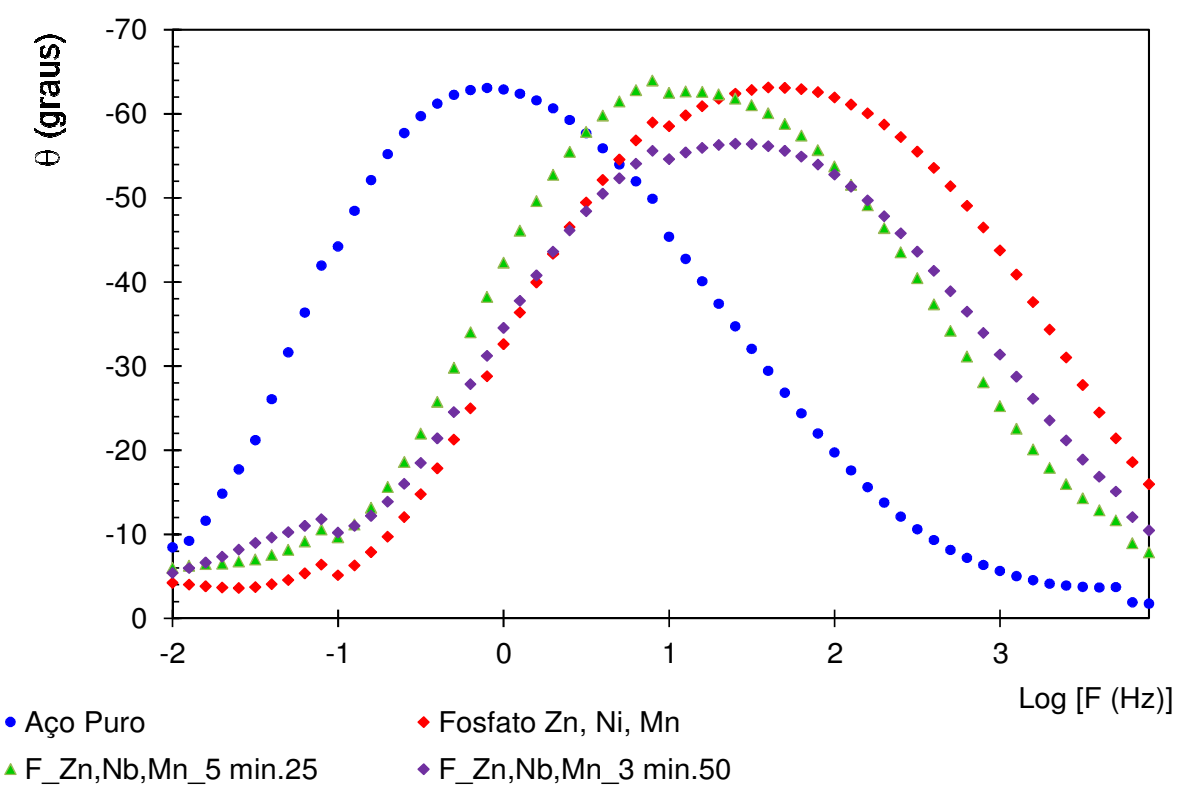

Figura 45. Diagramas de ângulo de fase de Bode para amostras de aço carbono 1005 sem revestimento e revestidas com fosfatos tricatiônicos, ensaiadas em solução de 0,5 mol.L ${ }^{-1}$ de $\mathrm{NaCl}$. 
Maiores impedâncias foram associadas ao fosfato obtido em solução de fosfatização com Zn, Mn e Ni em comparação com o fosfato com Zn, Mn e Nb, para as duas condições de fosfatização testadas. Comparando-se o efeito do tempo e temperatura, nota-se que melhores resultados foram associados à camada obtida por fosfatização durante 5 minutos em solução a $25^{\circ} \mathrm{C}$ em comparação à temperatura de $50{ }^{\circ} \mathrm{C}$ por 3 minutos. Maiores valores de impedância estão associados a uma maior resistência da placa metálica à corrosão superficial, o que no caso do fosfato com níquel pode ter decorrido de uma melhor cobertura cristalina apresentada por este fosfato (Figura 35).

Os diagramas de ângulo de fase de Bode mostram apenas uma constante de tempo para todos os sistemas testados. Para o aço sem revestimento, esta é observada em frequências próximas a $1 \mathrm{~Hz}$ e deve-se a processos de transferência de carga e carregamento da dupla camada elétrica. Já para as amostras com tratamento de fosfatização, a constante de tempo ocorre em maiores frequências, sendo observada a frequências próximas a $80 \mathrm{~Hz}$ para o fosfato tricatiônico de $\mathrm{Zn}$, Mn e $\mathrm{Ni}$, e para frequências entre 10 e $30 \mathrm{~Hz}$ para os fosfatos de $\mathrm{Zn}, \mathrm{Mn}$ e $\mathrm{Nb}$. O deslocamento observado nos diagramas de ângulo de fase de Bode para os resultados com fosfato em relação ao aço sem revestimento indica a presença de uma camada sobre o aço, o que está coerente com o que foi executado experimentalmente.

\subsubsection{Curvas de Polarização Potenciodinâmicas de Aços Fosfatizados}

As Figuras 46 e 47 apresentam as curvas de polarização potenciodinâmicas, catódicas e anódicas, para aço carbono sem revestimento; com revestimento de fosfato formado em banho de $\mathrm{Zn}$, Mn e Ni e em banho de fosfato de $\mathrm{Zn}$, Mn e $\mathrm{Nb}$, em condições de fosfatização diferentes, com base no concentrado laboratorial.

A Figura 46 mostra efeito da polarização da reação catódica para a camada de fosfato tricatiônico com níquel e pelas demais camadas de fosfato. Não sendo observado este efeito para o resultado com o aço sem revestimento, que registrou um aumento da densidade de corrente a partir de $-0,95 \mathrm{~V}$, aproximadamente. As curvas catódicas indicam controle da reação por difusão. Esta reação é provavelmente a de redução do oxigênio, controlada pelo processo de difusão deste na solução de ensaio. A polarização da reação anódica das amostras fosfatizadas apresentam-se semelhantes para os diversos tipos de 
camadas (Figura 47). As curvas de polarização mostram reações anódicas pouco polarizadas, indicando que o controle da reação de corrosão é pela reação catódica.

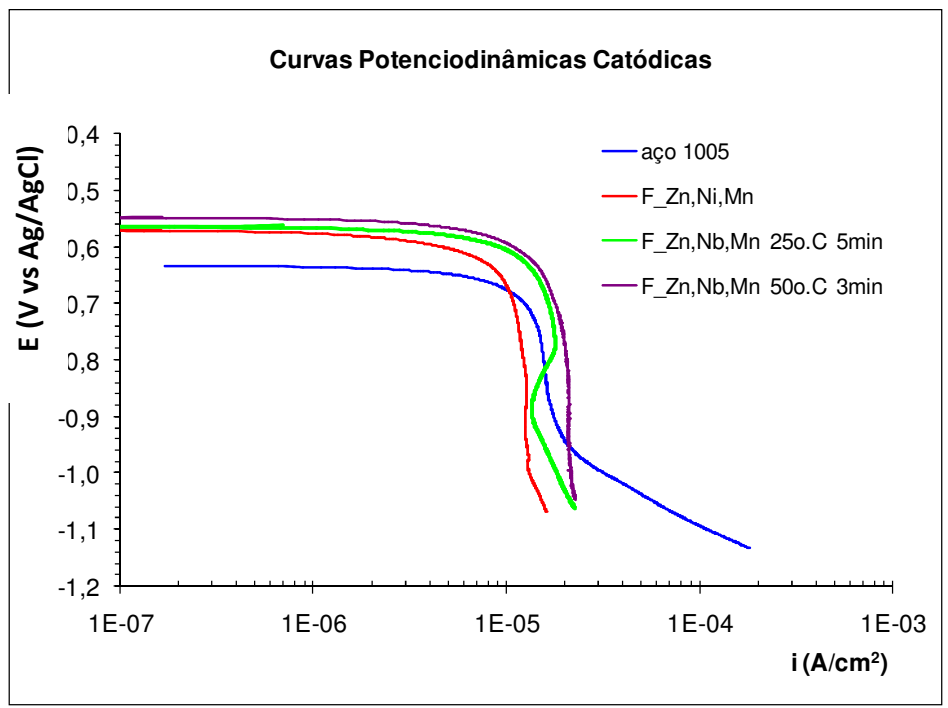

Figura 46. Curvas de polarização potenciodinâmicas catódicas para o aço carbono sem e com revestimentos de fosfatos.

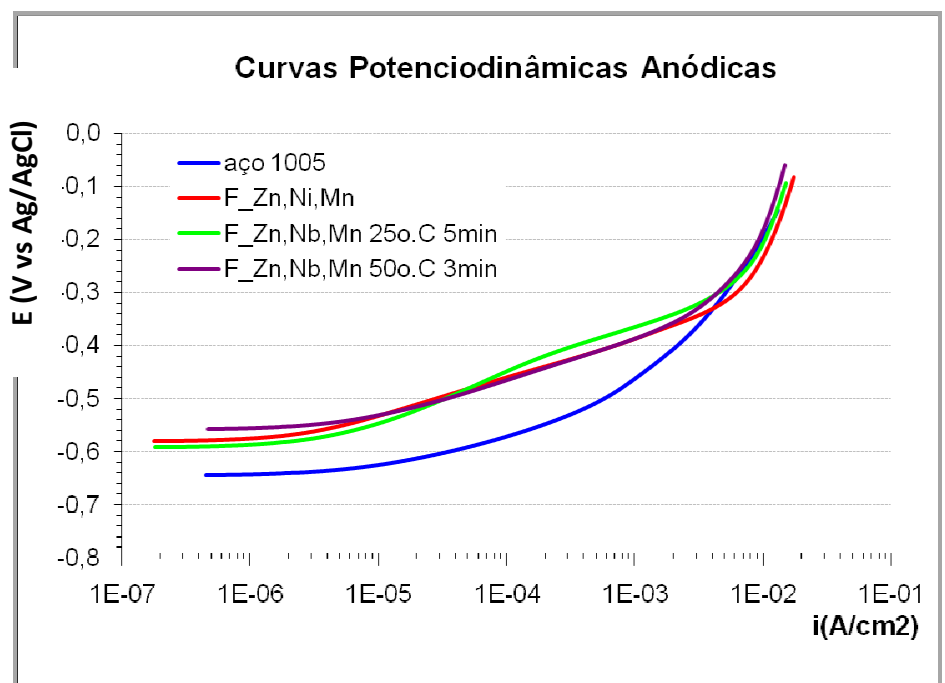

Figura 47. Curvas de polarização potenciodinâmicas anódicas para o aço carbono sem e com revestimentos de fosfatos. 


\section{CONSIDERAÇÕES PRELIMINARES}

I. Há uma relação entre a temperatura, tempo de imersão e concentração do acelerador, na formação das camadas de fosfato. Os resultados mostraram também que o aumento concomitante da temperatura e tempo de imersão, para uma dada concentração do acelerador, pode levar a falhas na cobertura cristalina.

II. Os resultados eletroquímicos indicaram que a camada de fosfato composta por $\mathrm{Zn}$, $\mathrm{Mn}$ e $\mathrm{Nb}$ fornece proteção contra corrosão do aço equivalente à proporcionada pela camada formada por $\mathrm{Zn}$, Mn e Ni.

III. A substituição do níquel pelo nióbio no fosfato tricatiônico alterou significativamente a morfologia da camada cristalina, tendo a camada com nióbio apresentado cristais com forma e tamanho diferentes. A inclusão do Nb no banho de fosfato de $\mathrm{Zn}$ e Mn foi essencial para uma completa cobertura do substrato, comprovando ser importante sua adição ao banho.

IV. As micrografias obtidas por MEV mostraram boa cobertura superficial do substrato pela camada de fosfato tricatiônico com nióbio.

V. As técnicas de espectroscopia de energia dispersiva, espectroscopia por infravermelho e difração de raios-X indicaram a presença de maior massa associada às camadas formadas com composto de nióbio.

Durante o desenvolvimento da parte inicial do programa experimental, a pesquisa foi sendo redirecionada no sentido de torná-la próxima a prática industrial. As informações obtidas durante esta fase inicial apontaram para a necessidade de troca dos banhos de fosfato até então utilizados, levando a uma reavaliação das camadas formadas, como também a influência das condições do banho de fosfatização. 


\section{RESULTADOS OBTIDOS COM CONCENTRADO INDUSTRIAL}

As camadas de fosfato passaram a ser obtidas usando-se o concentrado tricatiônico doado pela SurTec (ST 617), com e sem níquel.

Para a formulação com composto de nióbio, foi proposta a redução (orientada no boletim técnico) na concentração do acelerador de $\mathrm{NaNO}_{2}$ de 2 g.L $\mathrm{L}^{-1}$ para 1 g.L $\mathrm{L}^{-1}$, e o aumento da temperatura de $25{ }^{\circ} \mathrm{C}$ para $50{ }^{\circ} \mathrm{C}$, em relação às condições anteriormente definidas. A redução na concentração do acelerador é relevante no sentido de representar, também, uma redução na quantidade de lama de fosfatização gerada, que tende a aumentar com o aumento da concentração do acelerador. Resultados anteriores apoiaram a necessidade do ajuste no banho de fosfatização tricatiônica com composto de nióbio. $\mathrm{O}$ banho com níquel foi ajustado conforme orientação do boletim técnico SurTec ST617, considerando-se resultados já obtidos nesta pesquisa. Os novos banhos estão descritos na Tabela 22, e com base neles foram realizados os ensaios e análises apresentados a partir deste capítulo.

Tabela 22. Banhos de fosfato com base em concentrado industrial (ST617).

\begin{tabular}{c|c|c}
\hline \multicolumn{2}{c}{ Descrição dos Novos Banhos de Fosfato } \\
\hline $\begin{array}{c}\text { Referência do } \\
\text { concentrado }\end{array}$ & $\begin{array}{c}\text { Temperatura e tempo de } \\
\text { imersão no banho }\end{array}$ & $\begin{array}{c}\text { Tipo e concentração do acelerador } \\
\text { no banho }\end{array}$ \\
\hline ST617 Zn,Mn,Ni & $50^{\circ} \mathrm{C}$ por 5 minutos & Nitrito de sódio $\left(0,3\right.$ g.L $\left.\mathrm{L}^{-1}\right)$ \\
\hline ST617 Zn,Mn+Nb & $50^{\circ} \mathrm{C}$ por 5 minutos & Nitrito de sódio $\left(1,0\right.$ g.L.- $\left.{ }^{-1}\right)$ \\
\hline
\end{tabular}


8.1. Caracterização Superficial de Aços com Camadas de Fosfato Obtidas em Banhos com Base em Concentrado Industrial

\subsubsection{Ensaio Gravimétrico para as Camadas de Fosfato Obtidas em Banhos com Base em Concentrado Industrial}

Os resultados do ensaio gravimétrico permitiram o cálculo de valores de massa por área para as camadas de fosfato de zinco, manganês e níquel e de zinco, manganês e nióbio, nas condições descritas na Tabela 22. A Figura 48 apresenta a massa de fosfato obtida por unidade de área em função do tempo de imersão no banho de fosfatização, para a faixa de tempo entre 1 e 10 minutos. Segundo o Boletim Técnico SurTec 617, as camadas de fosfato de $\mathrm{Zn}, \mathrm{Mn}$ e $\mathrm{Ni}$, obtidas por processo de imersão podem apresentar entre $1,8 \mathrm{~g} \cdot \mathrm{m}^{-2}$ a $2,2 \mathrm{~g} \cdot \mathrm{m}^{-2}$, o que é compatível com os resultados obtidos no presente estudo.

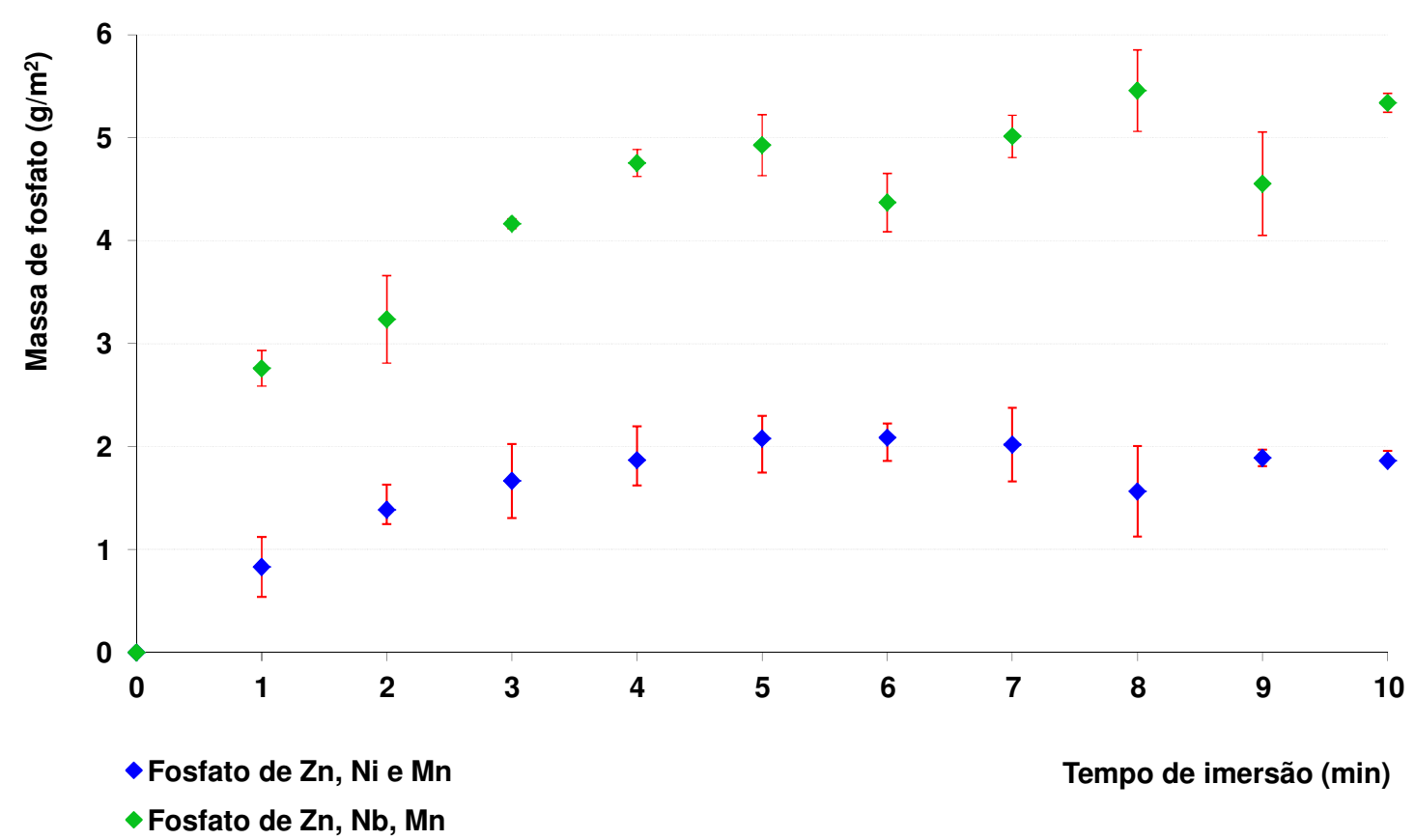

Figura 48. Variação de massa de fosfato em função do tempo de imersão no banho de fosfatização de Zn, Mn e Ni e de Zn, Mn e Nb. 
O tempo de 5 minutos para camada com níquel representa o tempo mínimo para estabilização camada de fosfato. A camada formada em banho com $\mathrm{Nb}$, apesar da maior variabilidade nos resultados, também apresentou o tempo de 5 minutos, como mínimo para estabilização da camada. Os resultados mostram que as duas camadas obtidas com os banhos de fosfato de base em concentrado industrial apresentam valores de massa por área dentro dos padrões esperados (de 1,0 a $7 \mathrm{~g} \cdot \mathrm{m}^{-2}$ ) para fosfatos de zinco e/ou fosfatos de zinco modificados (ditos tricatiônicos) [23, 24]. Foram obtidos 2,1 g.m ${ }^{-2}$ para a camada contendo Zn, Mn e Ni e 4,9 g.m $\mathrm{m}^{-2}$ para a camada contendo Zn, Mn e Nb.

Valores de massa por área das camadas de fosfato também foram avaliados através de medições realizadas por equipamento, Gardometer ${ }^{\circledR}$, de fabricação da Chemetall GmbH. Foram utilizadas 3 placas para cada tipo de fosfato, com $75 \mathrm{~mm}$ x $150 \mathrm{~mm}$ cada, sendo realizadas 3 medidas por lado de cada placa. A média encontrada para a camada com níquel foi de 2,3 g.m $\mathrm{m}^{-2}$ e 4,4 g.m $\mathrm{m}^{-2}$ para a camada de fosfato contendo composto de nióbio. Estes valores estão coerentes com os obtidos pelo ensaio gravimétrico.

\subsubsection{Microscopia Eletrônica de Varredura (MEV) de Aços com Camadas de Fosfato Obtidas em Banhos com Base em Concentrado Industrial}

As Figuras 49 e 50 apresentam micrografias por MEV para as camadas de fosfato de Zn, Mn, Ni e Zn, Mn, Nb em duas magnificações (500x e 1500x).

A troca do níquel pelo composto de nióbio produziu camada de fosfato com grãos de tamanhos variados, resultando em superfície mais irregular e heterogênea. Nesta camada são observados grãos em relevo. 

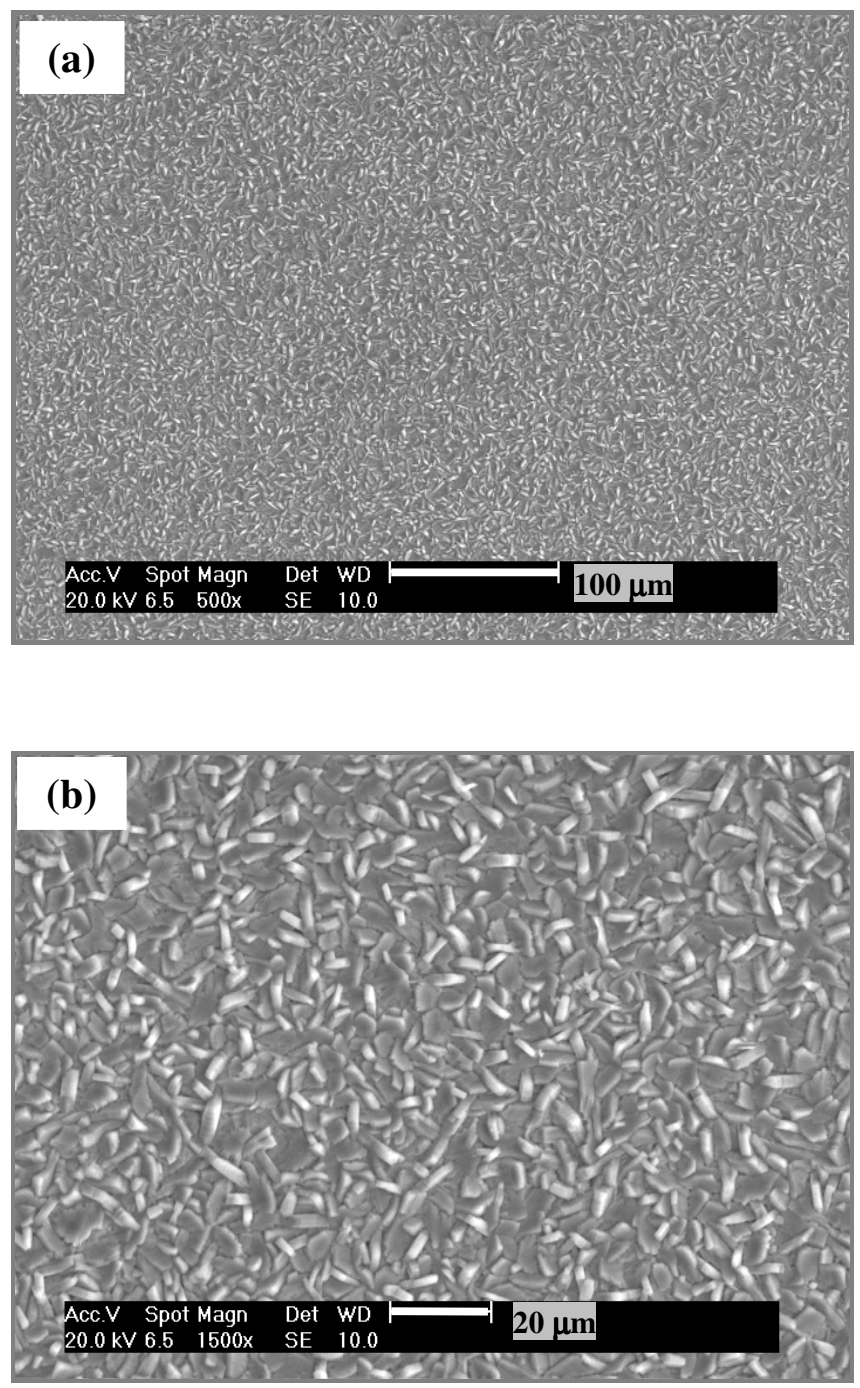

Figura 49. Micrografias obtidas por MEV do revestimento de fosfato composto por $\mathrm{Zn}$, Mn e Ni (imersão por 5 minutos, com 0,3 g. $\mathrm{L}^{-1}$ de $\mathrm{NaNO}_{2}, \mathrm{a} 50^{\circ} \mathrm{C}$ ). 

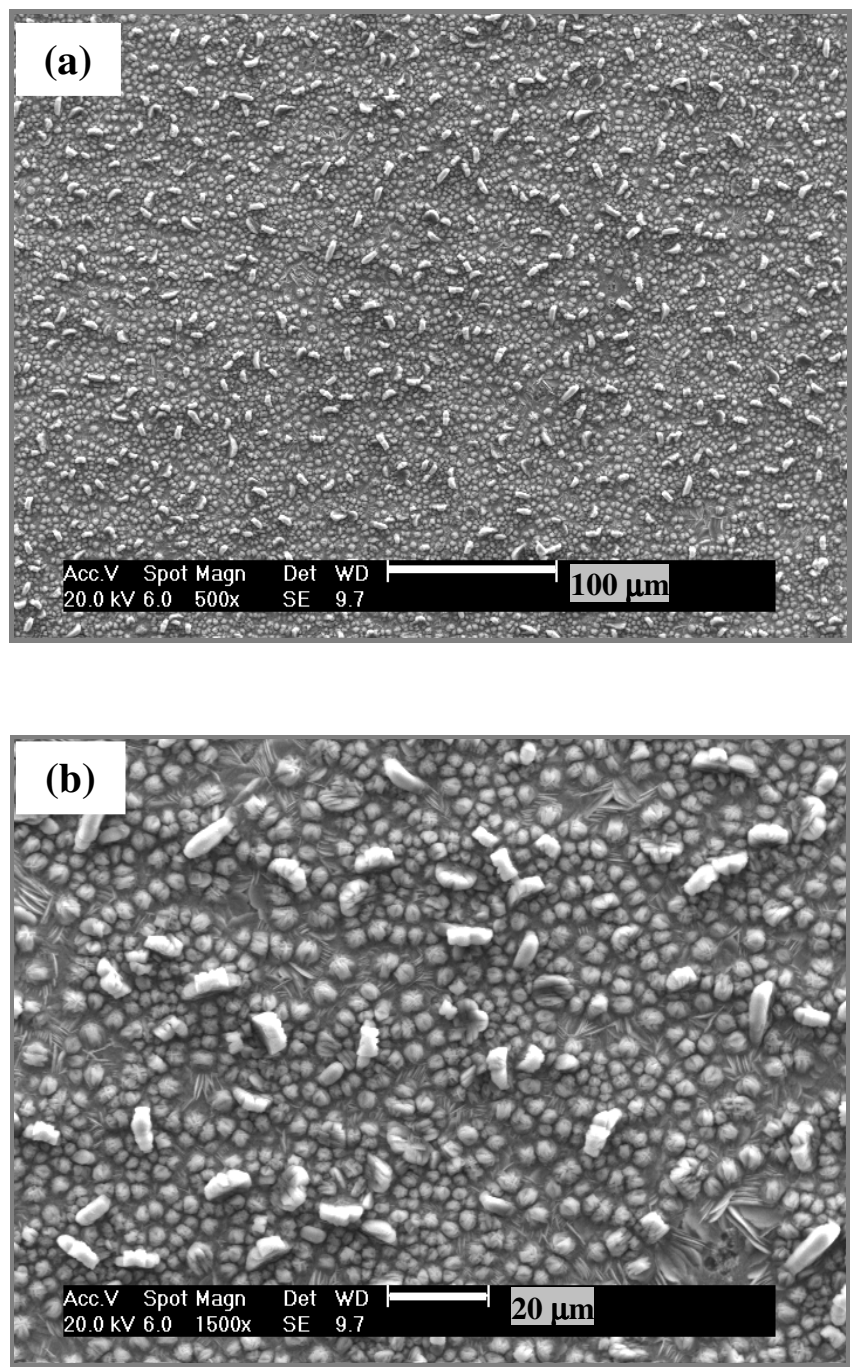

Figura 50. Micrografias obtidas por MEV do revestimento de fosfato composto por Zn, Mn e Nb (imersão por 5 minutos, com 1,0 g.L ${ }^{-1}$ de $\mathrm{NaNO}_{2}$, a $50{ }^{\circ} \mathrm{C}$ ).

8.1.3. Determinação da Composição das Camadas de Fosfato Obtidas em Banhos com Base em Concentrado Industrial

\subsubsection{Espectroscopia de Energia Dispersiva (EDS)}

A Figura 51 apresenta os elementos presentes nas camadas de fosfato obtidas pelo banho de fosfato de base industrial - SurtTec 617. E a Tabela 23 mostra a avaliação semiquantitativa dos elementos presentes. 

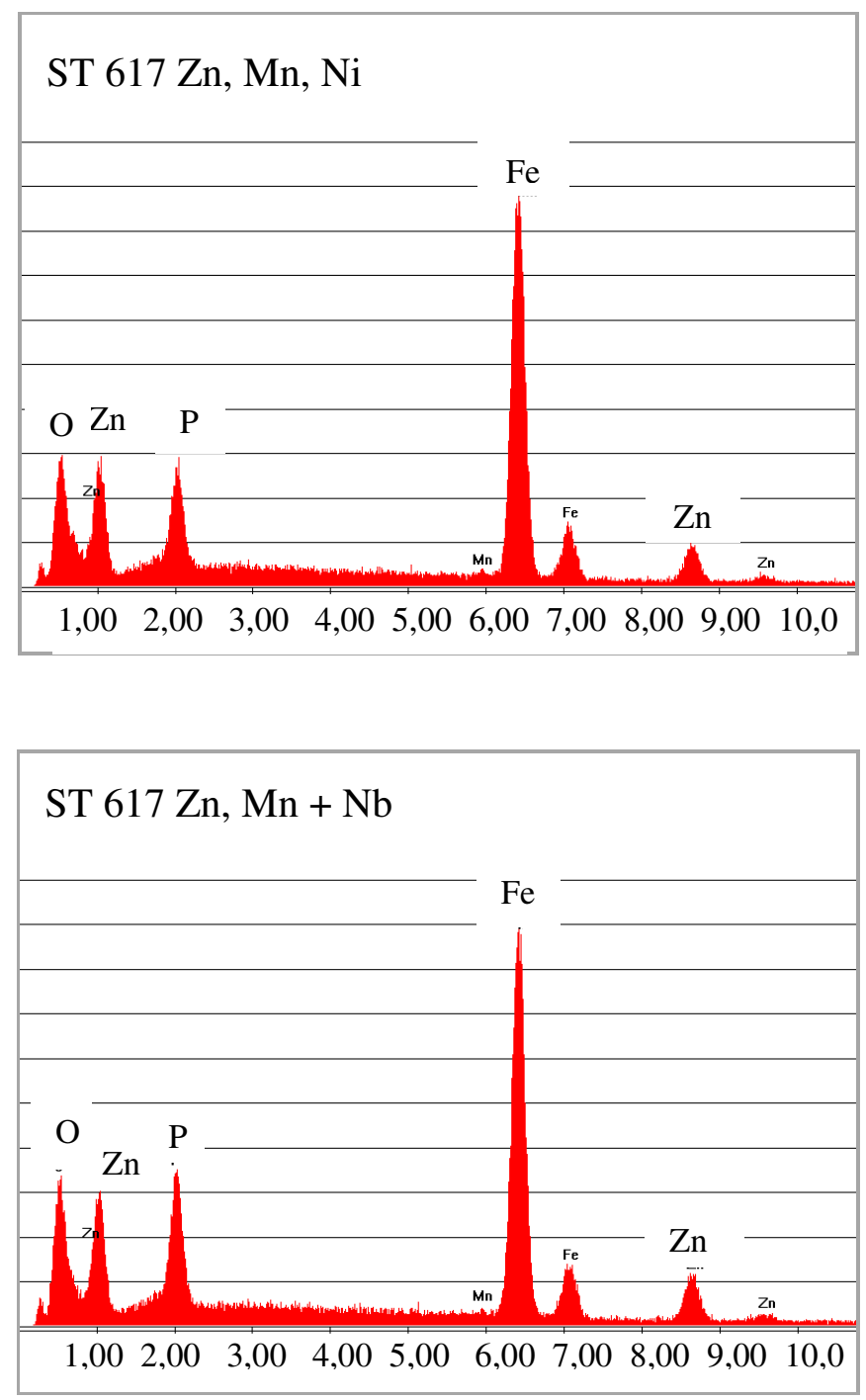

Figura 51. Espectros obtidos por EDS da superfície do aço com revestimento de fosfato.

Tabela 23. Análise semi-quantitativa da composição química por EDS das camadas de fosfato ST617 Zn,Mn,Ni e ST617 Zn,Mn+Nb.

\begin{tabular}{c|c|c}
\hline Elemento & $\begin{array}{c}\text { Fosfato ST617 Zn, Mn, Ni } \\
(\% \text { massa })\end{array}$ & $\begin{array}{c}\text { Fosfato ST617 Zn, Mn + Nb } \\
\text { (\% massa) }\end{array}$ \\
\hline $\mathbf{P}$ & 8,1 & 10,6 \\
\hline $\mathbf{M n}$ & 0,7 & 0,8 \\
\hline $\mathbf{F e}$ & 73,4 & 68,2 \\
\hline $\mathbf{Z n}$ & 17,8 & 20,4 \\
\hline
\end{tabular}


A Figura 51 sugere que, as concentrações de fósforo e oxigênio são praticamente iguais, ou seja, sugere que há a mesma concentração de fosfato na camada formada em presença do composto de nióbio em relação a de níquel. Na Tabela 23 observam-se valores pouco maiores para os elementos P, Mn e Zn no fosfato com nióbio.

\subsubsection{Espectroscopia por Infravermelho}

A Figura 52 apresenta os espectros das novas camadas de fosfato de Zn, Mn, Ni e $\mathrm{Zn}, \mathrm{Mn}, \mathrm{Nb}$. A configuração geral e posicionamento dos picos são semelhantes aos espectros obtidos anteriormente (Figuras 41 e 42). Apesar da troca do níquel pelo nióbio, não houve alteração nos picos relativos às absorções do fosfato $\left(500 \mathrm{e} 1200 \mathrm{~cm}^{-1}\right)$, como detalhado na Figura 52-(b). Estes resultados também são coerentes com espectros de fosfatos tricatiônicos encontrados na literatura [19, 39, 79]. A variação na massa superficial apresentada pelas curvas indicadas na Figura 52 é bem discreta.

Estudo realizado para diferentes camadas de fosfato, mono, bi e tricatiônico, sobre aço galvanizado, mostrou que a configuração geral desses espectros é bem semelhante à obtida no presente trabalho, havendo pequenas diferenças na posição das bandas, conforme dados apresentado na Tabela 24 [39].

Tabela 24. Posição das bandas no espectro de infravermelho de revestimentos de fosfatos sobre aço galvanizado [39].

\begin{tabular}{c|c|c|c|c|c}
\hline \multirow{2}{*}{ Camada } & \multicolumn{5}{|c}{ Posição das Bandas $\left(\mathbf{c m}^{-1}\right)$} \\
\cline { 2 - 6 } & $\boldsymbol{V}(\mathbf{O H})$ & $\boldsymbol{V}\left(\mathbf{H}_{\mathbf{2}} \mathbf{O}\right)$ & $\boldsymbol{\delta}\left(\mathbf{H}_{\mathbf{2}} \mathbf{O}\right)$ & $\boldsymbol{V}\left(\mathrm{PO}_{4}^{-3}\right)$ & $\boldsymbol{\delta}\left(\mathrm{PO}_{4}^{-3}\right)$ \\
\hline Zn, Mn, Ni & 3541 & 3276 & 1636 & $\begin{array}{c}1101 / 1066 \\
1018 / 994 \\
927\end{array}$ & 629 \\
\hline Hopeita & 3510 & 3265 & 1628 & $\begin{array}{c}1104 / 1067 \\
1019 / 1000 \\
935\end{array}$ & 631 \\
\hline Hopeita + Mn & 3535 & 3264 & 1627 & $\begin{array}{c}1106 / 1068 \\
1021 / 1001 \\
938\end{array}$ & 635 \\
\hline \multirow{2}{*}{ Hopeita + Ni } & 3528 & 3277 & 1627 & $\begin{array}{c}1102 / 1066 \\
1017 / 994 \\
929\end{array}$ & 628 \\
\hline
\end{tabular}




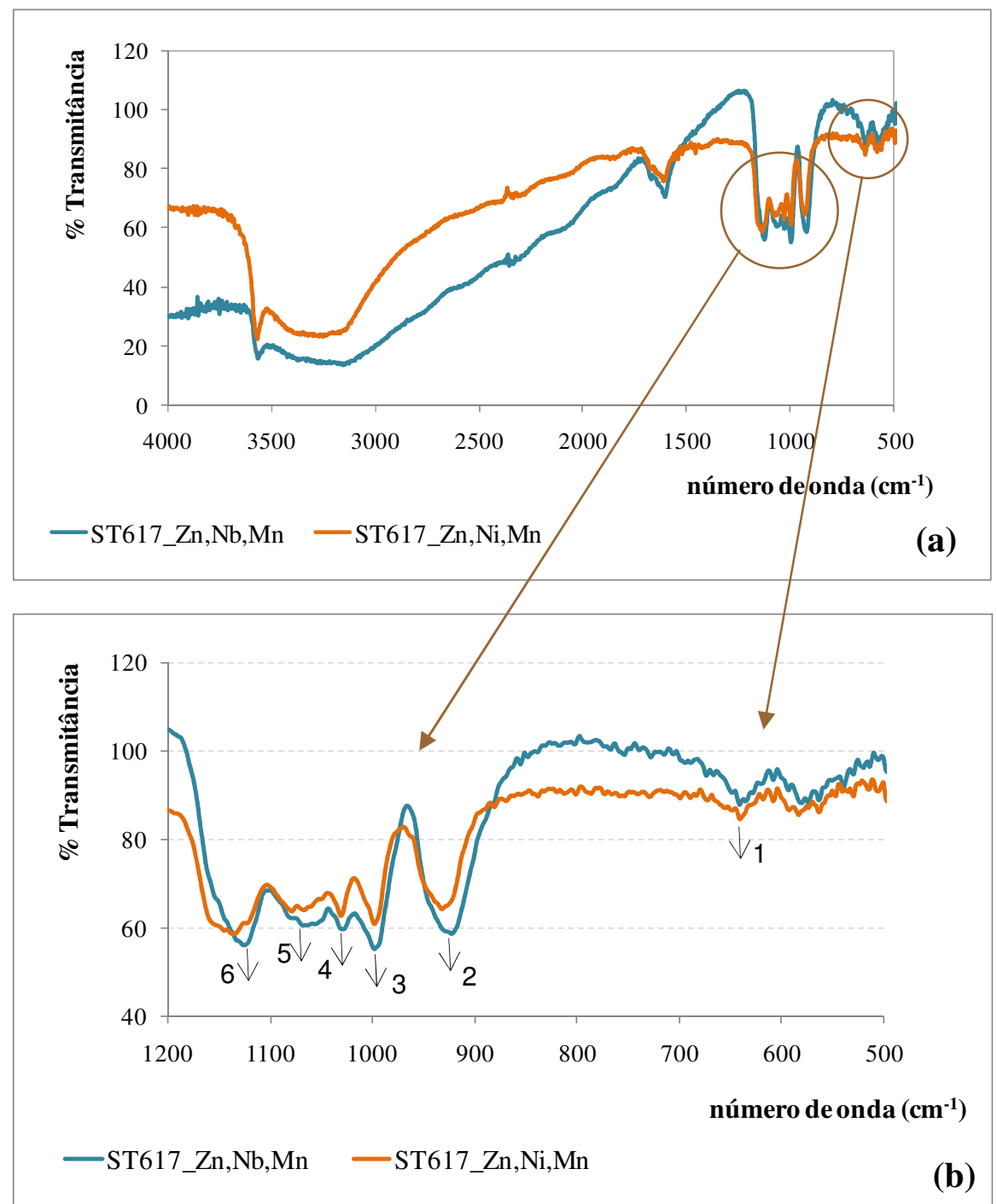

Figura 52. Espectros de fosfatos tricatiônicos obtidos por espectroscopia de infravermelho. (a) Intervalo entre $500 \mathrm{~cm}^{-1}$ a $4000 \mathrm{~cm}^{-1}$. (b) Ampliação do espectro para o intervalo entre $500 \mathrm{~cm}^{-1} \mathrm{e} 1200 \mathrm{~cm}^{-1}$.

De acordo com ASSAAOUDI, 2001 [80], o íon livre $\mathrm{PO}_{4}^{-3}$ apresenta quatro modos normais de vibração de um íon tetraédrico (estrutura molecular ilustrada na Figura 53), v1 - alongamento simétrico, v3 - alongamento assimétrico e v2 e V4 - vibrações de flexão. 

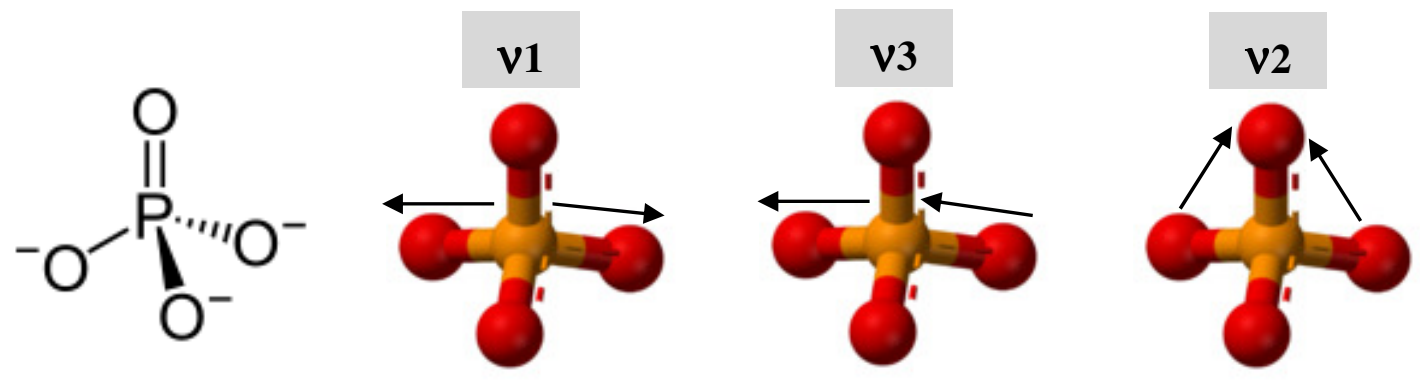

Figura 53. Estrutura molecular do fosfato.

A Tabela 25 relaciona estes modos de vibração com as bandas encontradas nos espectros dos fosfatos tricatiônicos para a faixa de absorção do fosfato, como apresentado na Figura 52-(b).

Tabela 25. Modos de vibração para as bandas encontradas nos fosfatos tricatiônicos de $\mathrm{Zn}$, Mn, Ni e de $\mathrm{Zn}$, Mn, Nb relacionados com os picos do espectro da Figura 52.

\begin{tabular}{|c|c|c|c|c|}
\hline \multirow[b]{2}{*}{ Camada } & \multicolumn{4}{|c|}{ Posição das Bandas para absorção do $\mathrm{PO}_{4}^{-3}\left(\mathrm{~cm}^{-1}\right)$} \\
\hline & $\begin{array}{c}\text { Pico } \mathrm{N}^{\mathrm{O}} 2 \\
\text { v1 }\end{array}$ & $\begin{array}{c}\text { Picos } N^{0 S} \\
6 / 5 / 4 / 3 \\
\text { v3 }\end{array}$ & $\begin{array}{c}\text { Pico } N^{0} 1 \\
\text { V4 }\end{array}$ & $\begin{array}{c}\text { Referência } \\
\text { [39] }\end{array}$ \\
\hline ST617 Zn, Mn, Ni & 928 & $\begin{array}{l}1132 \text { / } 1063 \\
1030 / 997\end{array}$ & 638 & $\begin{array}{l}\text { v1 - } 929 \\
\text { v3 - } 1105 / 1066\end{array}$ \\
\hline ST617 Zn, Mn + Nb & 920 & $\begin{array}{l}1122 / 1063 \\
1026 / 995\end{array}$ & 636 & $\begin{aligned} 1026 / 1000 \\
v 4-635\end{aligned}$ \\
\hline
\end{tabular}

\subsubsection{Difração de Raios X}

A Figura 54 a seguir apresenta os resultados da analise por difração de raios-X das camadas de fosfato. Esta mostra as mesmas fases presentes em ambas as camadas de fosfato formadas, seja em solução com $\mathrm{Ni}$ ou com $\mathrm{Nb}$, especificamente fosfofilita (1), hopeita (2) e ferro (3). 

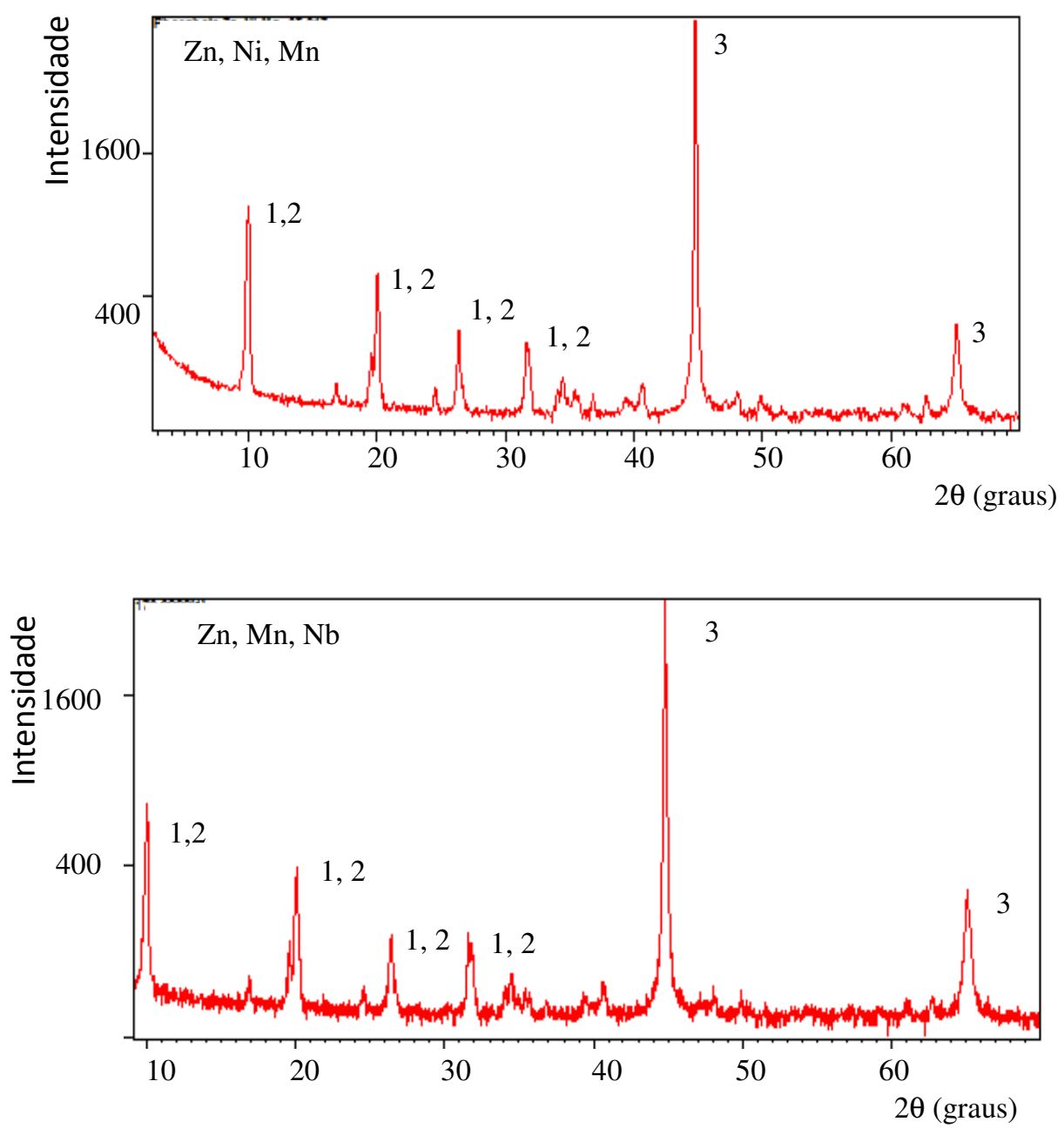

Figura 54. Difratograma de raios-X do aço carbono com revestimentos de fosfato tricatiônico (Zn, Mn, Nb) onde (1) fosfofilita, (2) hopeita e (3) ferro .

Os difratogramas da Figura 54 apresentam configuração igual aos da Figura 43, e também indicam que a fosfofilita aparece em maior quantidade que a hopeita, porém devido a estas fases ocorrerem para as mesmas posições angulares, fica difícil a visualização individual. Isto acontece devido ao fato de camadas de fosfatos de zinco obtidas em banhos com adição de manganês e níquel, apresentaram-se isomorfas em relação a hopeita [39], como pode-se observar na Figura 55. Nesta figura, nota-se que a camada de fosfato de zinco sobre aço galvanizado [81] apresenta a hopeita exatamente na posição onde nos difratogramas de fosfato tricatiônico pode-se observar também a fosfofilita. 


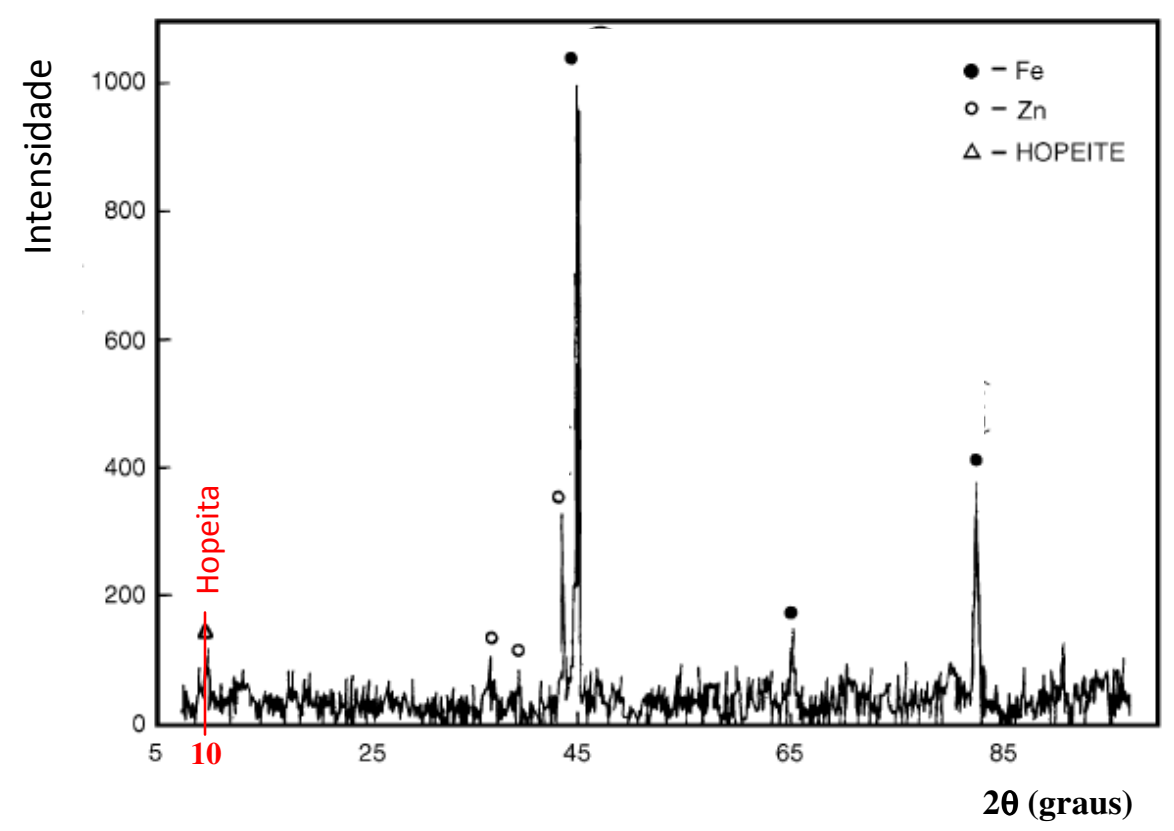

Figura 55. Difratograma de raios-X padrão para revestimento de fosfato de zinco em substrato de aço zincado [81].

\subsubsection{Espessura das Camadas}

A Tabela 26 mostra o resumo das médias das espessuras obtidas. Os resultados referentes à espessura das camadas de fosfato apresentaram variação entre $1 \mu \mathrm{m}$, no mínimo e $5 \mu \mathrm{m}$ no máximo, sendo a média aritmética de todos os valores encontrados igual a 2,5 $\mu \mathrm{m}$. Medidas obtidas para as placas com fosfato e revestimento de tinta eletroforética, ficaram entre $24 \mu \mathrm{m}$ e $27 \mu \mathrm{m}$, com média geral igual a $25 \mu \mathrm{m}$. A literatura [82] indica espessuras de cerca de $2,5 \mu \mathrm{m}$ para camada de fosfato de zinco e níquel com valor de massa por área igual a 2,5 g.m $\mathrm{m}^{-2}$. Revestimentos de fosfato com valor de massa por área entre 1,5 e 2,0 g.m $\mathrm{m}^{-2}$ podem apresentar espessura da ordem de $1 \mu \mathrm{m}$ [19]. 
Tabela 26. Valores de espessura, desvio padrão e médias para camadas de fosfatos com e sem tinta.

\begin{tabular}{c|c|c|c|c|c|c}
\hline $\begin{array}{c}\text { Tipo de } \\
\text { fosfato }\end{array}$ & $\begin{array}{c}\text { Fosfato } \\
\text { Média Arit. }\end{array}$ & $\begin{array}{c}\text { Desvio } \\
\text { padrão }\end{array}$ & $\begin{array}{c}\text { Média } \\
\text { geral }\end{array}$ & $\begin{array}{c}\text { Fosfato + tinta. } \\
\text { Média Arit. }\end{array}$ & $\begin{array}{c}\text { Desvio } \\
\text { padrão }\end{array}$ & $\begin{array}{c}\text { Média } \\
\text { geral }\end{array}$ \\
\cline { 1 - 1 } $\mathrm{Zn}, \mathrm{Mn}, \mathrm{Ni}$ & $2,1 \mu \mathrm{m}$ & 0,5 & \multirow{2}{*}{$2,5 \mu \mathrm{m}$} & $26 \mu \mathrm{m}$ & 0,8 & \multirow{2}{*}{$25 \mu \mathrm{m}$} \\
\cline { 1 - 1 } $\mathrm{Zn}, \mathrm{Mn}, \mathrm{Nb}$ & $2,9 \mu \mathrm{m}$ & 1,3 & & $24 \mu \mathrm{m}$ & 0,5 & \\
\hline
\end{tabular}

É possível também estimar a espessura de uma camada de conversão relacionando a massa por área $\left(\mathrm{g} . \mathrm{m}^{-2}\right)$ com a densidade aparente da camada formada $\left(\mathrm{g} . \mathrm{cm}^{-3}\right)$. Esta densidade é função da porosidade e rugosidade superficial, e sua irregularidade dificulta uma determinação precisa. Porém valores entre 0,9 e $2,5 \mathrm{~g} . \mathrm{cm}^{-3}$ são comumente adotados para revestimentos de conversão. No caso de camadas de fosfato pode-se usar o valor médio 1,7 g. $\mathrm{cm}^{-3}$, considerando-se um erro de $\pm 45 \%$ [50].

Tomando como base os valores acima descritos e o valor de massa por área das camadas (item 8.1.1), a espessura das novas camadas de fosfato pode ser calculada segundo a equação [50]:

Densidade aparente $\left(\mathrm{g} / \mathrm{cm}^{3}\right)=\frac{\text { peso da camada }\left(\mathrm{g} / \mathrm{m}^{2}\right)}{\operatorname{espessura}(\mu \mathrm{m})}$

Desta maneira, a camada de $\mathrm{Zn}, \mathrm{Mn}, \mathrm{Ni}$ apresenta espessura aproximada de 1,2 $\mu \mathrm{m}$. Considerando o erro de $45 \%$, o valor da espessura fica entre 0,66 e 1,74 $\mu \mathrm{m}$.

Para a camada de fosfato de $\mathrm{Zn}, \mathrm{Mn}$ e $\mathrm{Nb}$ a espessura resulta em 2,9 $\mu \mathrm{m}$, com intervalo entre 1,6 e 4,2 $\mu \mathrm{m}$ (erro de 45\%). Os valores obtidos pela Equação 14 também estão próximos ao intervalo de 1 a $5 \mu \mathrm{m}$, encontrado nas medidas realizadas neste trabalho. Os valores de espessura obtidos são semelhantes aos praticados na indústria e aos indicados em referências bibliográficas [52, 82, 83]. 


\subsection{Avaliação Eletroquímica da Resistência à Corrosão das Camadas de Fosfato Obtidas em Banhos com Base em Concentrado Industrial}

As Figuras 56 a 60 apresentam os resultados de espectroscopia de impedância eletroquímica e curvas de polarização para os aços com camadas de fosfato obtidas em banhos com Ni ou com $\mathrm{Nb}$.

\subsubsection{Espectroscopia de Impedância Eletroquímica de Aços com Camadas de} Fosfato Obtidas em Banhos com Base em Concentrado Industrial

Os resultados apresentados nas Figuras 56 e 57 correspondem a diagramas de Nyquist para seis amostras de aço com camada de fosfato de Zn, Mn e Ni e de Zn, Mn e $\mathrm{Nb}$, respectivamente, após duas horas de imersão em meio de 0,5 mol. $\mathrm{L}^{-1}$ de $\mathrm{NaCl}$. E a Figura 58 apresenta o diagrama de ângulo de fase de Bode, para os maiores valores de impedância encontrados nos diagramas de Nyquist.

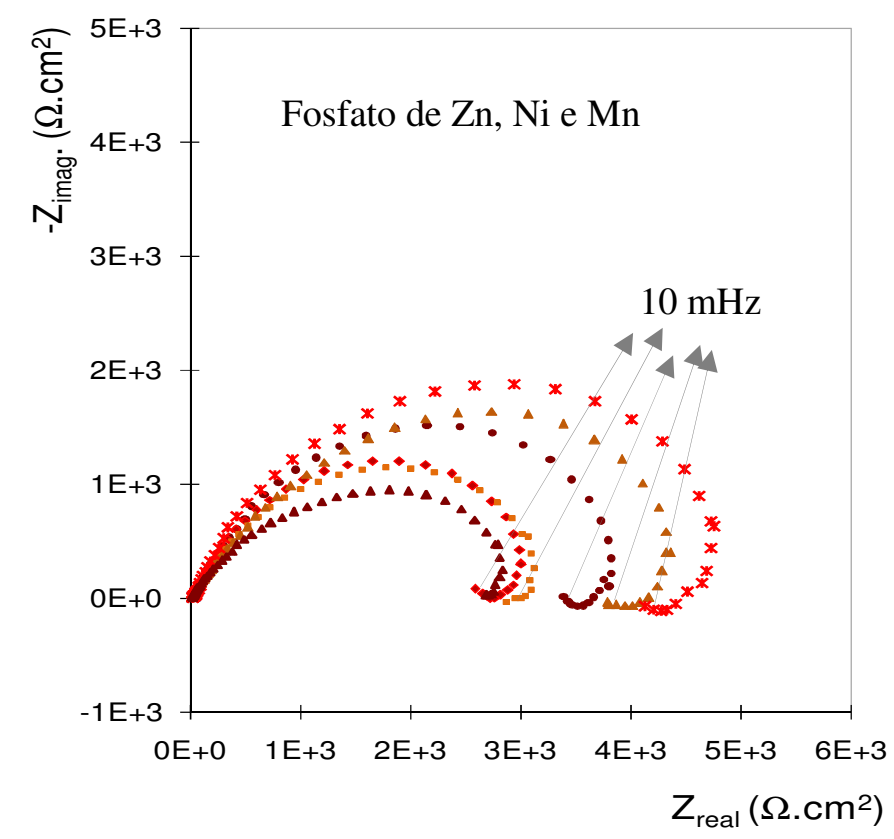

Figura 56. Diagramas de Nyquist para amostras de aço carbono 1005 com camada de fosfato de $\mathrm{Zn}$, Mn e Ni obtida a $50^{\circ} \mathrm{C}$ durante 5 minutos de imersão. Ensaios realizados em meio de $0,5 \mathrm{~mol} \mathrm{~L}^{-1}$ de $\mathrm{NaCl}$, após $2 \mathrm{~h}$ de imersão. 


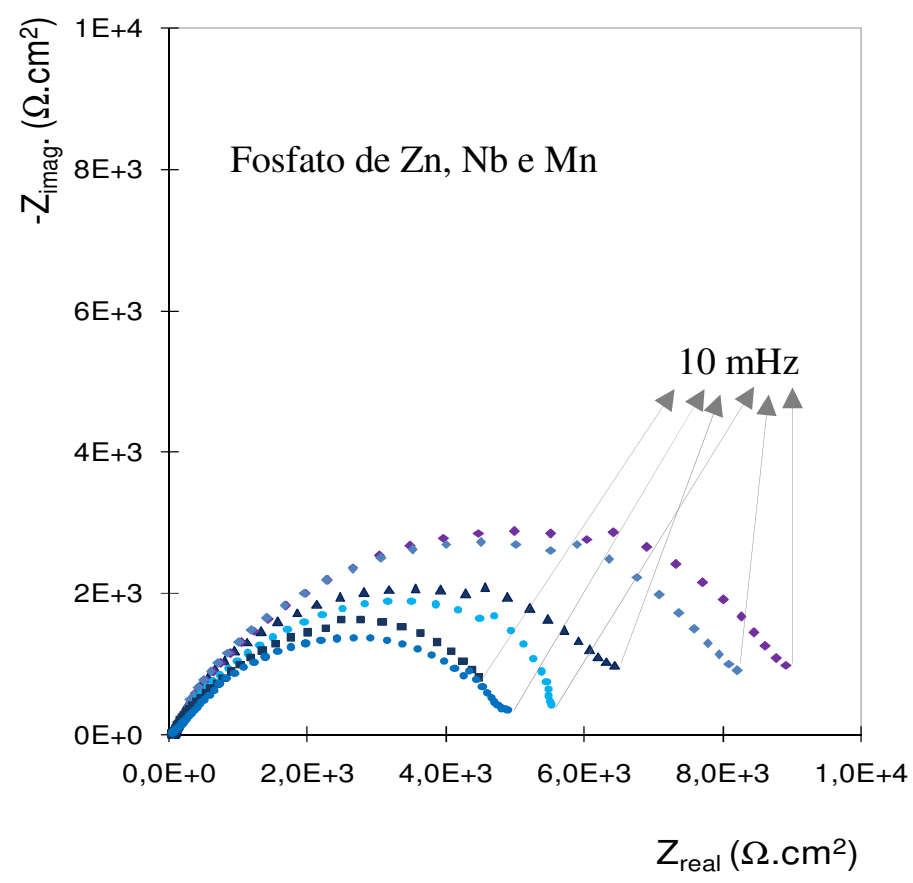

Figura 57. Diagramas de Nyquist para amostras de aço carbono 1005 com camada de fosfato de $\mathrm{Zn}$, Mn e $\mathrm{Nb}$ obtida a $50{ }^{\circ} \mathrm{C}$ durante 5 minutos de imersão. Ensaios realizados em meio de $0,5 \mathrm{~mol} \mathrm{~L}^{-1}$ de $\mathrm{NaCl}$, após $2 \mathrm{~h}$ de imersão.

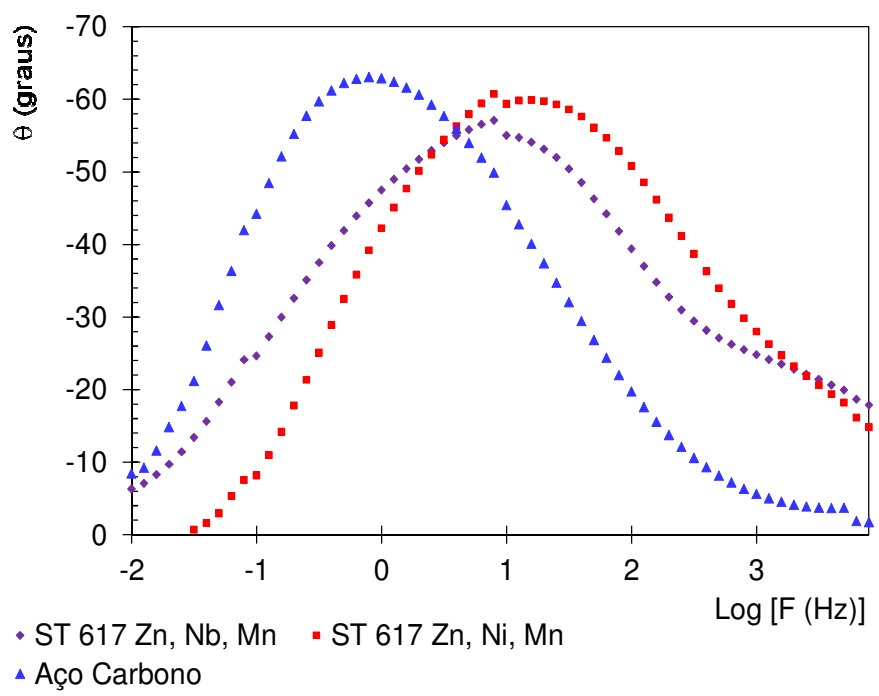

Figura 58. Diagramas de ângulo de fase de Bode para amostras de aço carbono 1005 com camadas de fosfato de $\mathrm{Zn}$, Mn, $\mathrm{Nb}$ e $\mathrm{Zn}$, Mn, Ni obtidas a $50^{\circ} \mathrm{C}$ durante 5 minutos de imersão. Ensaios realizados em meio de $0,5 \mathrm{~mol} \mathrm{~L}^{-1}$ de $\mathrm{NaCl}$, após $2 \mathrm{~h}$ de imersão. 
As Figuras 56 e 57 mostram diagramas de Nyquist com formatos similares para as amostras com um mesmo tipo de camada, apesar da variabilidade na grandeza da impedância; o que seria esperado, em se tratando de camadas porosas. DE LEVIE [84] demonstrou que o ângulo de fase de um processo difusivo no interior de um poro corresponde à metade daquele usualmente encontrado para difusão de um eletrodo plano, que é de 45 graus. Observando-se o diagrama de ângulo de fase de Bode (Figura 58), os resultados com fosfato indicam a presença de uma segunda constante de tempo para altas frequências em torno de 22,5 graus, indicativo portanto da característica porosa do revestimento de fosfato.

Os formatos semelhantes dos diagramas de Nyquist para um mesmo tipo de camada sugerem mecanismos também similares. Maiores impedâncias foram sempre associadas com as camadas obtidas com fosfato contendo $\mathrm{Nb}$ comparativamente às obtidas em presença de Ni. Foi observado um arco indutivo em baixas frequências para todas as amostras testadas com camada de fosfato com Ni. Este arco indutivo pode estar associado com a adsorção de íons cloreto no substrato metálico (aço), levando ao ataque corrosivo deste. A indicação de adsorção de íons cloreto nas camadas com Ni sugere mais fácil acesso de espécies agressivas através destas até o substrato metálico, provavelmente por esta se tratar de camada menos compacta que a obtida em presença de composto de $\mathrm{Nb}$.

\subsubsection{Curvas de Polarização Potenciodinâmicas de Aços com Camadas de Fosfato Obtidas em Banhos com Base em Concentrado Industrial}

As Figuras 59 e 60 apresentam as curvas de polarização das amostras de aço com camadas de fosfato de $\mathrm{Zn}, \mathrm{Mn}$ e $\mathrm{Nb}$, e $\mathrm{Zn}, \mathrm{Mn}$ e Ni respectivamente. E a Figura 61 apresenta um comparativo entre as camadas de fosfato. 

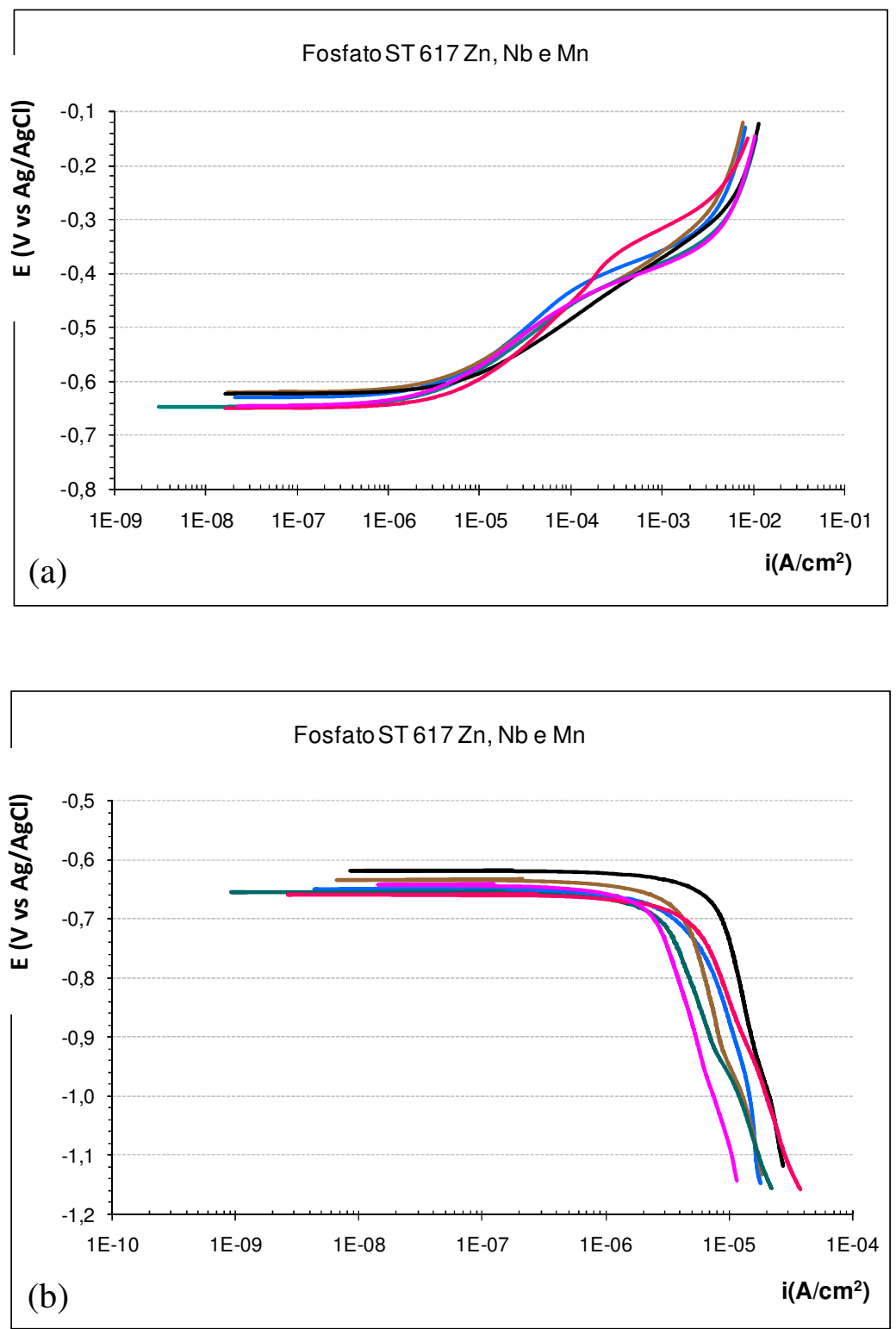

Figura 59. Curvas de polarização potenciodinâmicas anódicas (a) e catódicas (b) para o aço carbono com revestimento de $\mathrm{Zn}$, Mn e Nb. Ensaios realizados para 3 horas de imersão em meio de 0,5 mol.L $\mathrm{L}^{-1}$ de NaCl. 

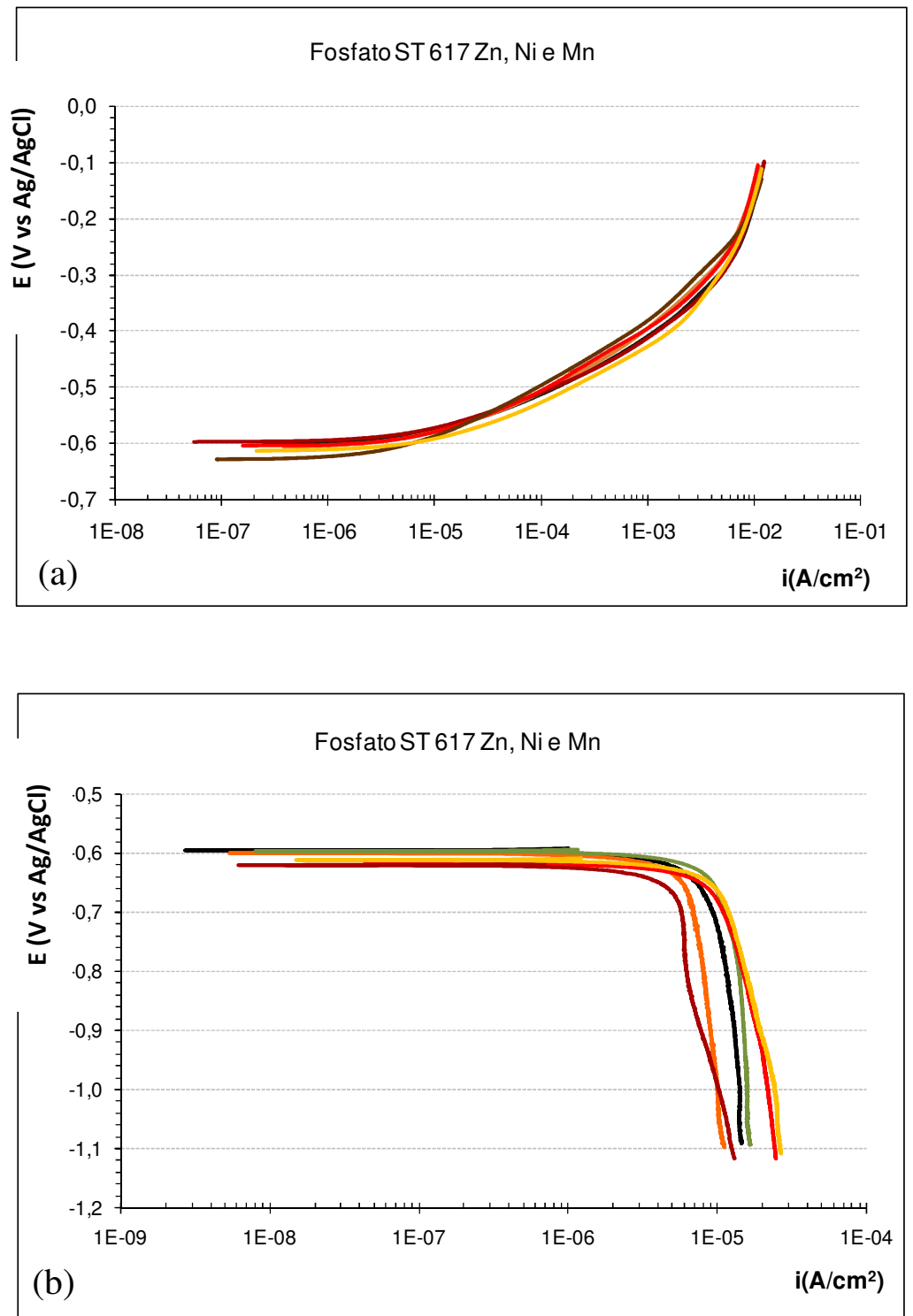

Figura 60. Curvas de polarização potenciodinâmicas anódicas (a) e catódicas (b) para o aço carbono com revestimento de Zn, Mn e Ni. Ensaios realizados para 3 horas de imersão em meio de 0,5 mol. $\mathrm{L}^{-1}$ de $\mathrm{NaCl}$. 

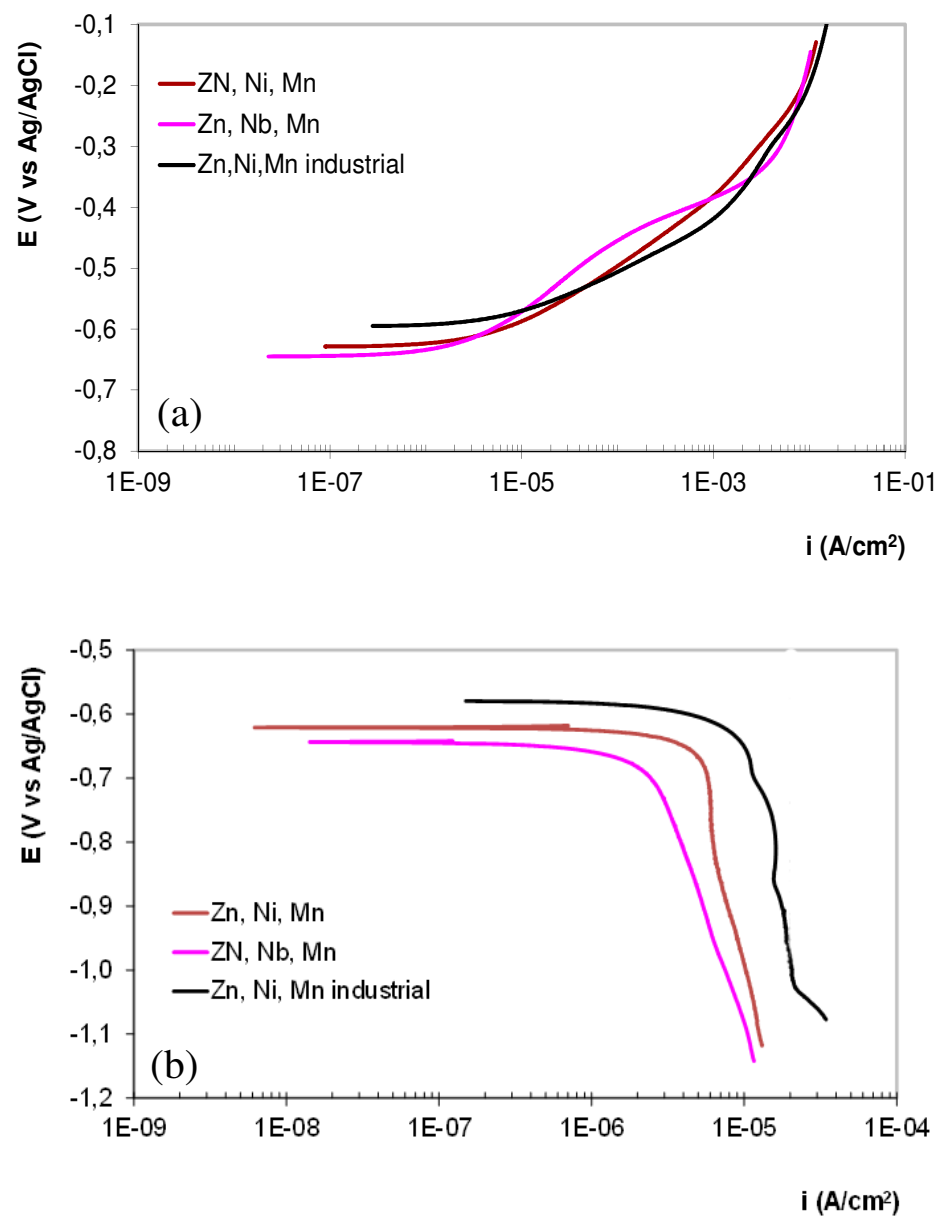

Figura 61. Curvas de polarização potenciodinâmicas anódicas (a) e catódicas (b) de aços fosfatizados em banhos de $\mathrm{Zn}, \mathrm{Mn}, \mathrm{Ni}$; Zn, Mn, Nb e tricatiônico industrial. Ensaios realizados para 3 horas de imersão em meio de 0,5 mol.L ${ }^{-1}$ de $\mathrm{NaCl}$.

Na Figura 61 a camada referida como "Zn,Ni,Mn industrial” apresenta o resultado de amostras de aço fosfatizadas ( $\mathrm{Zn}, \mathrm{Mn}$ e Ni) e passivadas diretamente em linha de processo da indústria automobilística, por aspersão (3 minutos), à aproximadamente $50{ }^{\circ} \mathrm{C}$. O processo de aspersão naturalmente resulta em camadas com menor resistência a corrosão devido a uma presença preponderante da hopeita (CHEEVER ${ }^{25}$ apud GENTIL) [9]. O resultado obtido em linha industrial vem mostrar que a camada de fosfato com composto de nióbio atende aos padrões hoje adotados neste meio, em relação aos resultados obtidos pelas curvas de polarização potenciodinâmicas.

${ }^{25}$ CHEEVER, G. D. Journal of Paint Technology, 39, 504 (1967). 
Comparando-se as outras camadas com $\mathrm{Ni}$ e $\mathrm{Nb}$, as curvas de polarização anódica mostram reação mais polarizada no caso das amostras com camada de fosfato com $\mathrm{Nb}$ em comparação com a de fosfato com $\mathrm{Ni}$, o que apoia os resultados anteriores de espectroscopia de impedância eletroquímica que indicam maior impedância e, portanto, uma camada mais compacta em relação à obtida em solução com Ni. Propõe-se que isto ocorra devido à maior proteção do substrato em consequência da fosfatização em solução contendo composto de $\mathrm{Nb}$. Isto poderia ocorrer seja pela presença de uma camada de fosfato mais compacta, o que foi também sugerido pela observação e comparação da morfologia das camadas de fosfato tricatiônico (item 8.1.2), ou pela formação de um filme passivo sobre substrato metálico, já durante o processo de fosfatização.

As curvas de polarização catódicas foram muito similares no caso dos dois tipos de camada, indicando controle difusional para os dois tipos de fosfato e densidades de corrente limite próximas. Estes resultados indicam que a maior resistência da camada de fosfato com $\mathrm{Nb}$, indicada pelas maiores impedâncias, deve-se preferencialmente à polarização da reação anódica provavelmente pela presença de uma camada mais espessa e/ou compacta devido à modificação na morfologia dos cristais formados em presença de $\mathrm{Nb}$ comparativamente à camada de $\mathrm{Ni}$, ou mesmo, conforme mencionado acima, à formação de um filme passivo sobre o substrato metálico durante a fosfatização.

\subsection{Resultado da Passivação com Oxalato de Nióbio e Amônio}

Este item apresenta os resultados da avaliação de soluções de passivação para aços fosfatizados através da cronoamperometria, e os resultados da avaliação de amostras sequencialmente fosfatizadas e passivadas, através de curvas potenciodinâmicas anódicas e catódicas e por espectroscopia de impedância eletroquímica.

Às soluções originalmente tamponadas (Tabela 17), usadas nos ensaios de cronoamperometria, foi adicionado oxalato de nióbio e amônio, como descrito no item 5.4.8. A adição deste composto provocou redução no valor do $\mathrm{pH}$ original, devido a sua acidez, como indicado na Tabela 27. Os resultados das curvas cronoamperométricas estão apresentados nas Figuras 62 e 63 e mostram que na presença do oxalato de nióbio ocorre redução da corrente de corrosão. 
Tabela 27. Efeito da adição do oxalato de nióbio e amônio no pH do eletrólito.

\begin{tabular}{c|c|c}
\hline \multicolumn{3}{|c}{ Soluções Tamponadas } \\
\hline pH sem Nb & pH com 200 mg.L $^{-1}$ Nb & pH com $\mathbf{4 0 0}$ mg.L ${ }^{-1}$ Nb \\
\hline 6 & 5.3 & 4.0 \\
\hline 8 & 7.4 & 6.8 \\
\hline
\end{tabular}
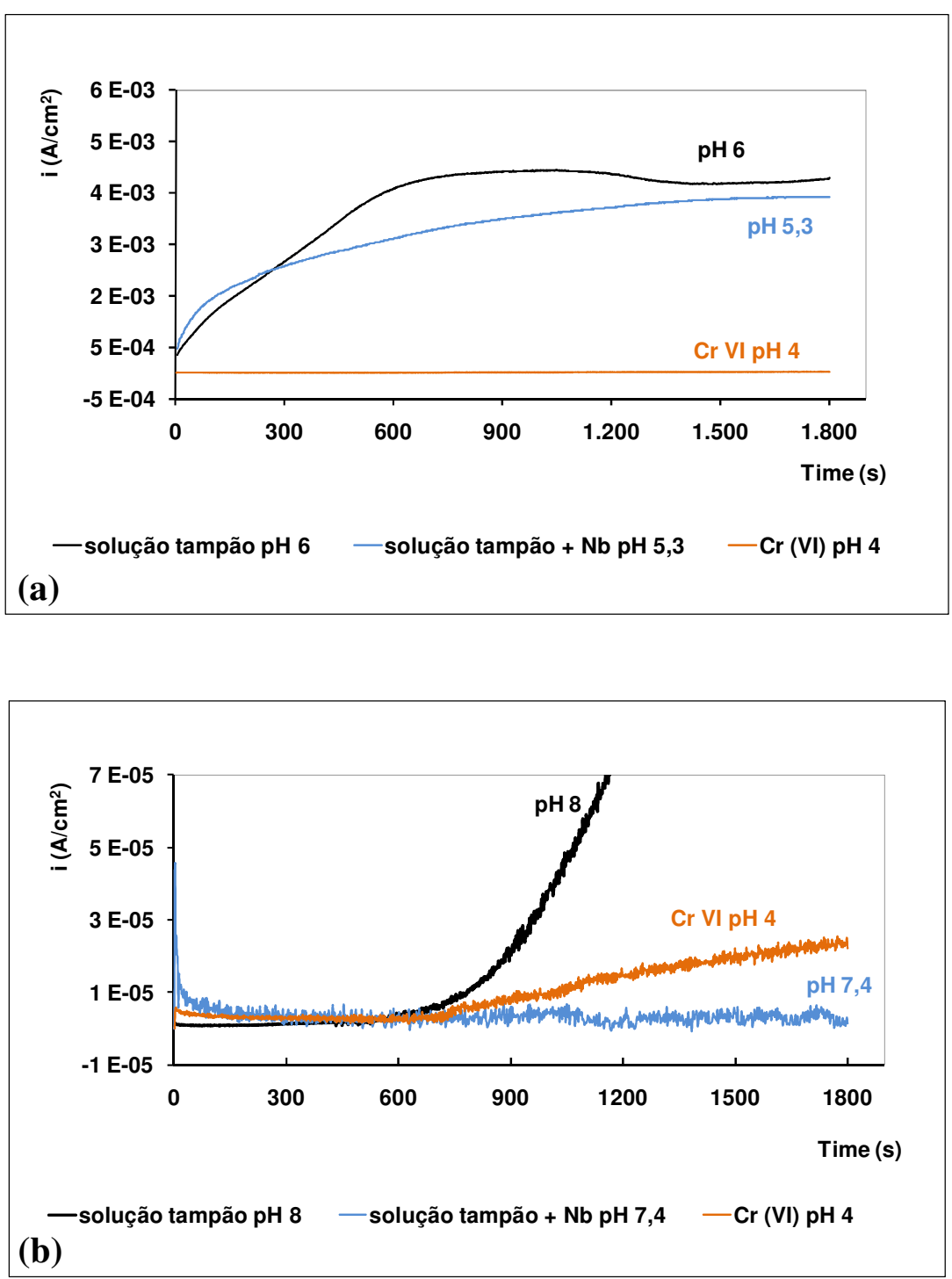

Figura 62. Curvas cronoamperométricas de aços fosfatizados em banho de Zn, Mn e $\mathrm{Nb}$ imersos em soluções tamponadas com e sem nióbio (200 mg. $\left.\mathrm{L}^{-1}\right)$. (a) Soluções tampão originalmente com pH 6. (b) Soluções tampão originalmente com pH 8. Comparadas à passivação em solução de cromo hexavalente (pH 4). 

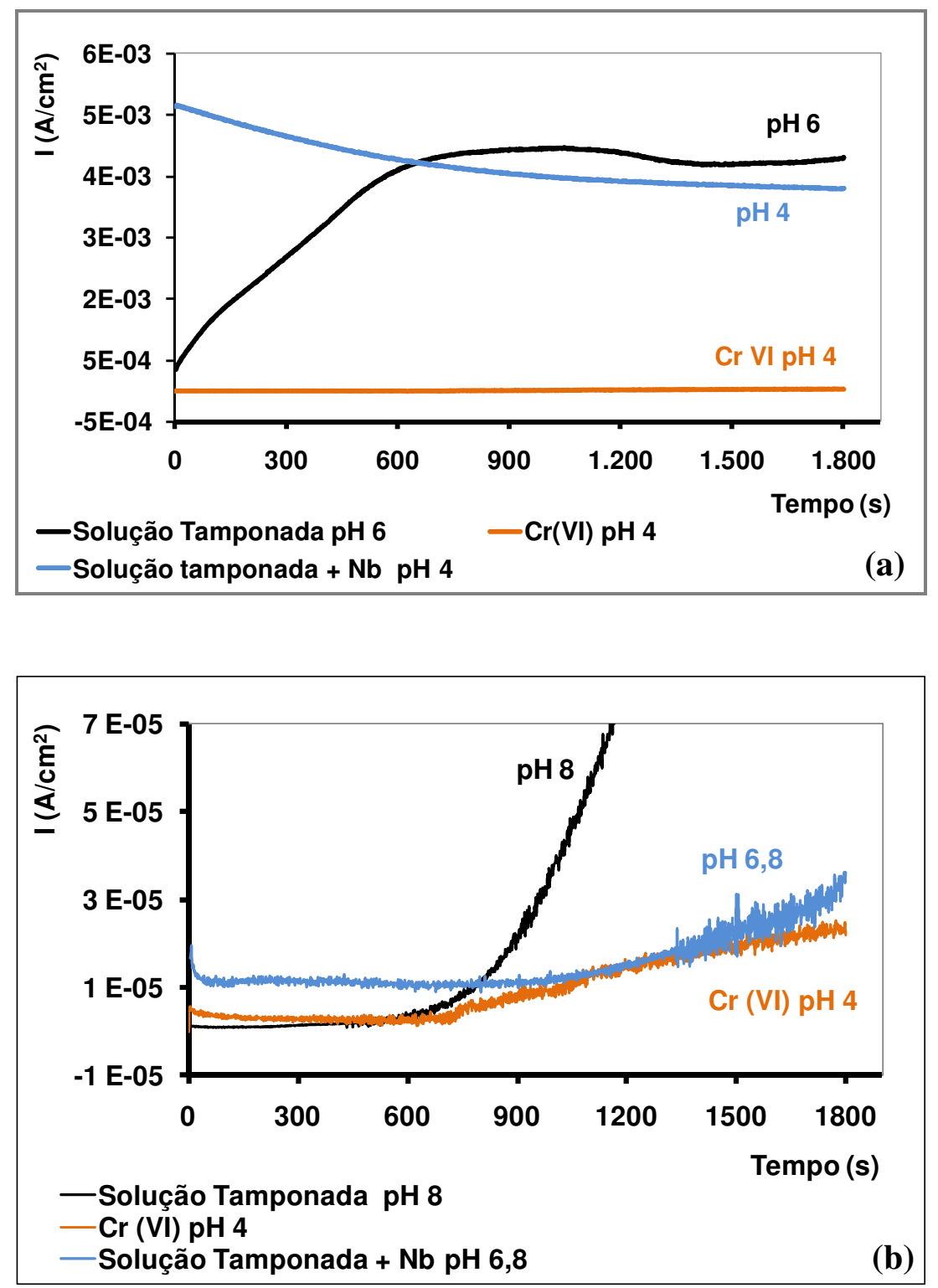

Figura 63. Curvas cronoamperométricas de aços fosfatizados em banho de Zn, Mn e $\mathrm{Nb}$ imersos em soluções tamponadas com e sem nióbio (400 mg. $\mathrm{L}^{-1}$ ). (a) Soluções tampão originalmente com pH 6. (b) Soluções tampão originalmente com pH 8.

Comparadas à passivação em solução de cromo hexavalente (pH 4).

A densidade de corrente do aço fosfatizado e imerso na solução com $200 \mathrm{mg} . \mathrm{L}^{-1}$ de $\mathrm{Nb}$ (Figura 62a), tanto para $\mathrm{pH}$ igual a6 como para $\mathrm{pH}$ igual a 5,3, foi sempre superior à obtida em solução com $\mathrm{CrO}_{3}$. Em meio ligeiramente alcalino sem adição de composto de $\mathrm{Nb}$ ( $\mathrm{pH}$ igual a 8), a densidade de corrente, inicialmente próxima às obtidas para meio com 
$\mathrm{CrO}_{3}$, aumentou significativamene após $600 \mathrm{~s}$ de imersão, indicando ataque da camada de fosfato e/ou do substrato (Figura 62b). Todavia, na solução com pH 7,4, foram observadas menores densidades de corrente do que na solução com $\mathrm{CrO}_{3}$, o que sugere ausência de ataque à camada de fosfato e passivação do substrato para a solução com Nb (Figura 62b).

Já em soluçôes com $400 \mathrm{mg} . \mathrm{L}^{-1}$ de composto de $\mathrm{Nb}$ e com pH igual a 4 ou 6 , as densidades de corrente foram sempre maiores, mesmo na solução de passivação com $\mathrm{Nb}$ do que no meio com $\mathrm{CrO}_{3}$ (Figura 63a).

Os resultados em soluções com $\mathrm{CrO}_{3}$ foram apenas comparáveis aos da solução com $\mathrm{Nb}$ em pH aproximadamente neutro (6,8) (Figura 63b), o que pode ser atribuído à baixa agressividade do meio à camada de fosfato. Para esta solução, a corrente diminuiu nos momentos iniciais, e estabilizou durante certo período, passando a ser da mesma ordem das obtidas em solução com $\mathrm{CrO}_{3}$. Esses resultados sugerem o efeito benéfico do oxalato de nióbio e amônio em $\mathrm{pH}$ aproximadamente neutro, na proteção contra corrosão do substrato. Com a finalidade de investigar este efeito, amostras de aço foram fosfatizadas e passivadas, pela imersão em soluções de $200 \mathrm{mg} . \mathrm{L}^{-1}$ de $\mathrm{Nb}\left(\mathrm{pH} \mathrm{7,4}\right.$ a $25^{\circ} \mathrm{C}$ por $\left.120 \mathrm{~s}\right) \mathrm{e}$ pela imersão em soluções com passivador Dream 401-A, a base de $\mathrm{CrO}_{3}(0,03 \%$ v/v a 25 ${ }^{\circ} \mathrm{C}$ por $60 \mathrm{~s}$ ). Essas amostras foram submetidas à avaliação eletroquímica em soluções de cloreto de sódio $\left(0,2\right.$ mol. $\left.\mathrm{L}^{-1}\right)$. Os resultados estão apresentados nas Figuras 64 e 65. 


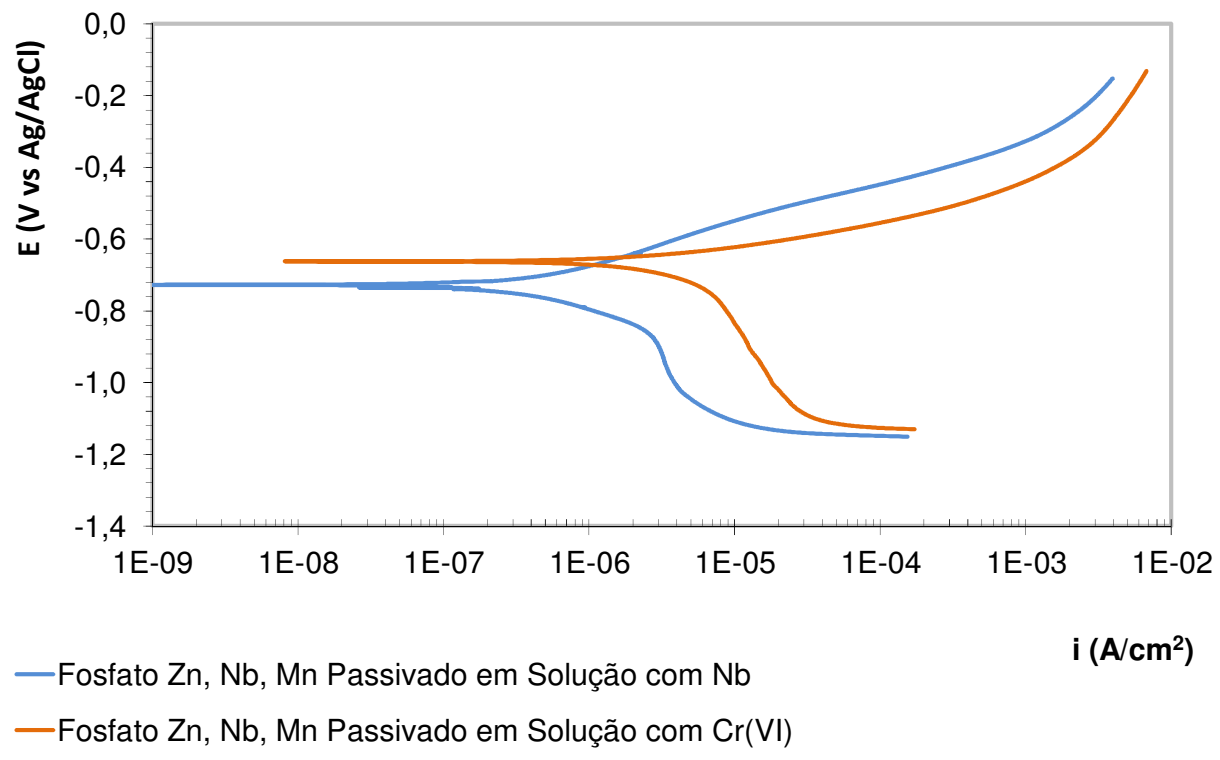

Figura 64. Curvas de polarização anódicas e catódicas do aço fosfatizado (Zn, Mn e $\mathrm{Nb}$ ) e passivado em soluções com $\mathrm{Nb}_{\text {ou }} \mathrm{CrO}_{3}$. Resultados obtidos em solução 0,2 mol $\mathrm{L}^{-1}$ de $\mathrm{NaCl}$.

A Figura 64 compara as curvas de polarização (anódica e catódica) de amostras passivadas em soluções contendo $\mathrm{CrO}_{3}$ e composto de $\mathrm{Nb}$. Menores densidades de corrente, tanto anódicas quando catódicas, foram associadas a este último tipo de solução. Ambas as reações, catódicas e anódicas, foram comparativamente mais polarizadas para amostras passivadas em solução com oxalato de nióbio e amônio do que em soluções com $\mathrm{CrO}_{3}$, provavelmente devido à passivação do substrato metálico.

Os resultados da espectroscopia de impedância eletroquímica (EIE), apresentados na Figura 65 apoiam essas indicações, apresentando maiores impedâncias associadas às amostras passivadas em soluções com composto de $\mathrm{Nb}$ em comparação com a passivação pelo $\mathrm{CrO}_{3}$. Estes resultados sugerem que o tratamento em solução com composto de $\mathrm{Nb}$ com $\mathrm{pH}$ igual a 7,4 resulta na passivação do substrato e em uma superfície com maior resistência à corrosão em comparação à passivação em solução com $\mathrm{CrO}_{3}$. 


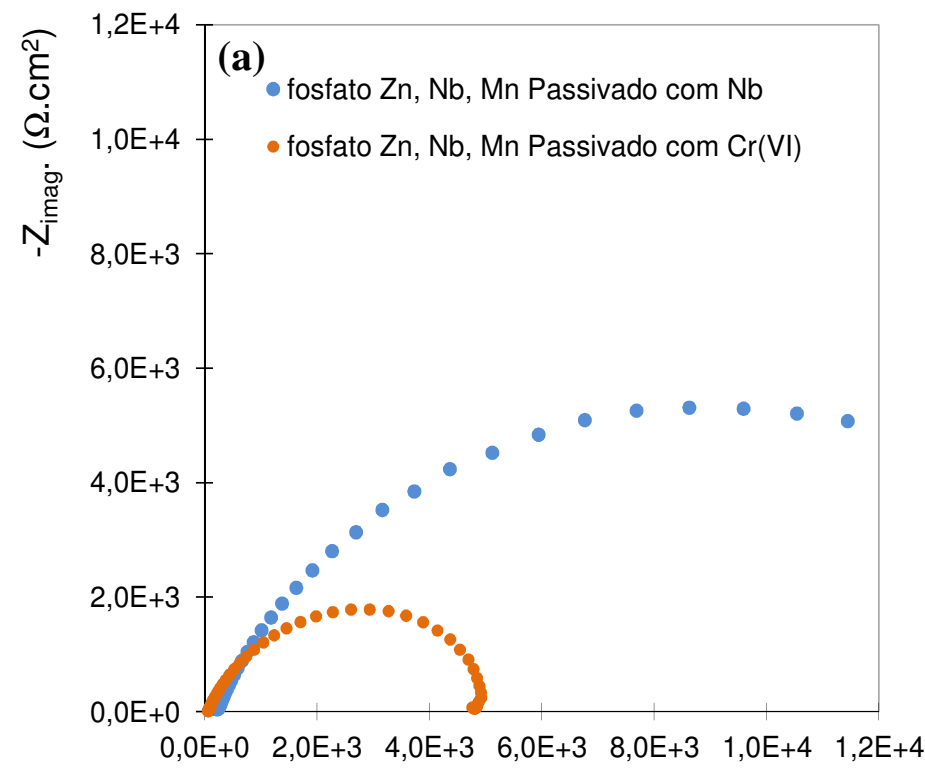

$Z_{\text {real }}\left(\Omega . \mathrm{cm}^{2}\right)$

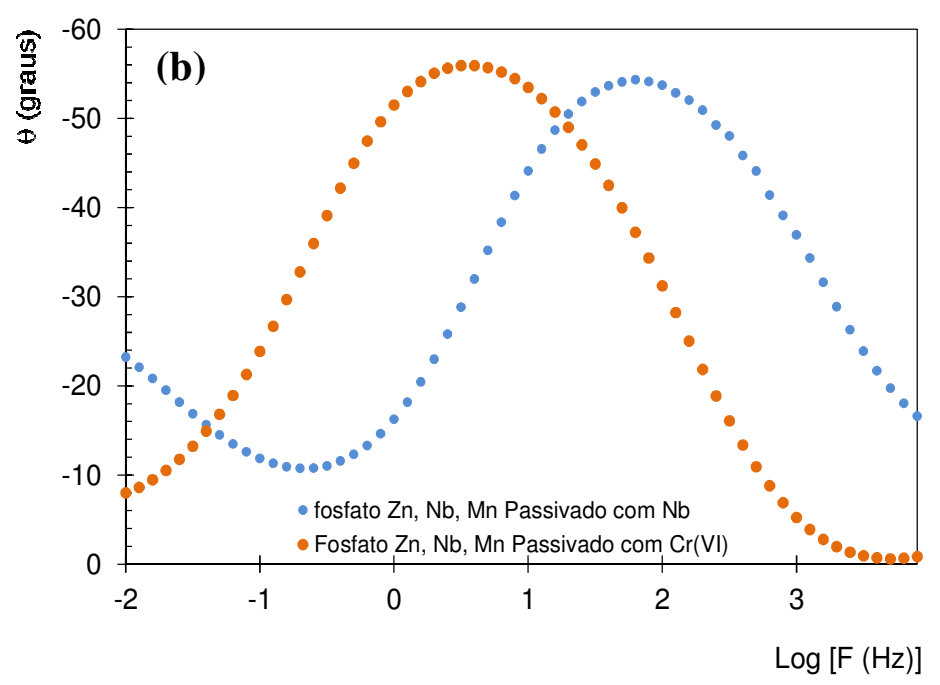

Figura 65. Resultados de EIE: (a) Diagramas de Nyquist e (b) Diagramas de ângulo de fase de Bode de aço fosfatizado ( $\mathrm{Zn}, \mathrm{Mn}$ e $\mathrm{Nb}$ ) e passivado em soluções com composto de $\mathrm{Nb}$ ou $\mathrm{CrO}_{3}$. Resultados obtidos em solução 0,2 mol.L ${ }^{-1} \mathrm{NaCl}$ após $2 \mathrm{~h}$ de imersão.

Os resultados apresentados mostram a possibilidade da atuação do composto de nióbio como passivador de aço com camadas de fosfato tricatiônico, em substituição ao cromo hexavalente. 


\subsection{Ensaio de Névoa Salina e Determinação da Aderência de Tintas}

Para o ensaio de névoa salina amostras de aço foram fosfatizadas em banhos ST617 $\mathrm{Zn}, \mathrm{Mn}, \mathrm{Ni}$ e ST617 Zn, Mn+Nb e após esta etapa receberam camada de tinta eletroforética. A Figura 66 ilustra as placas de aço, com e sem fosfatização.
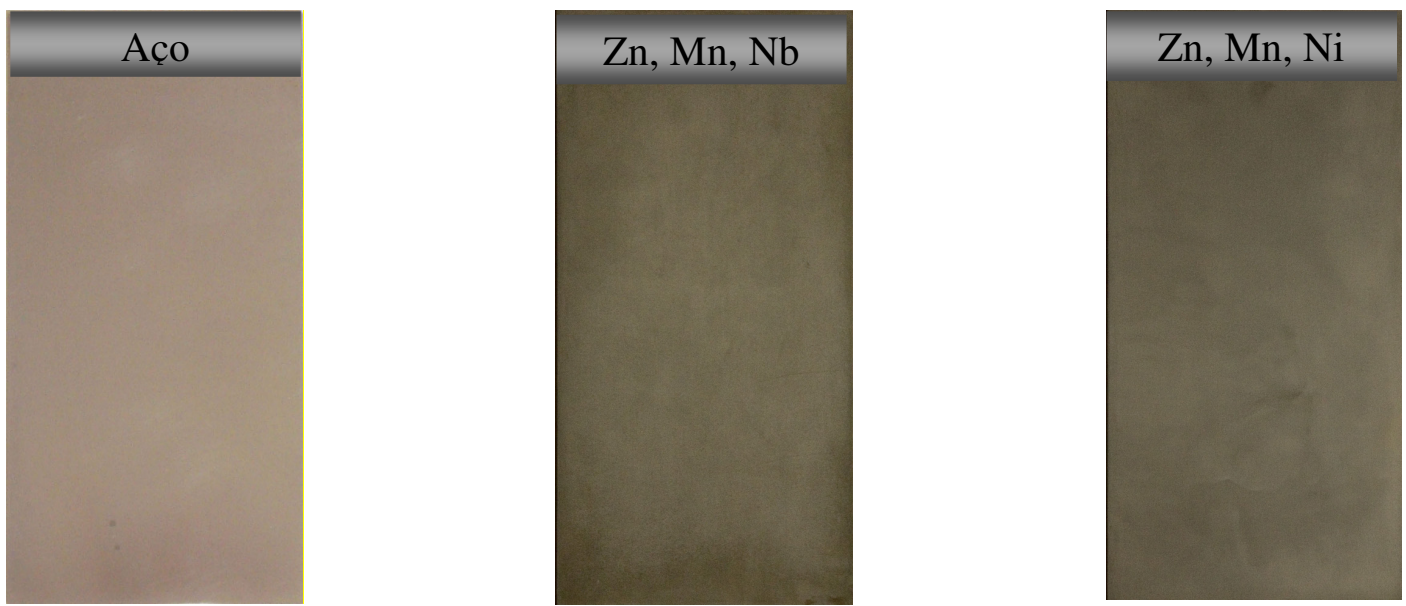

Figura 66. Placas de aço sem revestimento e fosfatizadas em banhos tricatiônicos.

As placas fosfatizadas e sem revestimento foram imersas em tinta KTL CathoGuard 310 (BASF) por 4 minutos, e na sequência permaneceram em estufa à $180{ }^{\circ} \mathrm{C}$ por 15 minutos, em linha de produção da indústria automobilística. A Figura 67 mostra a fixação das placas antes da pintura por imersão na linha industrial e após pintura e secagem.
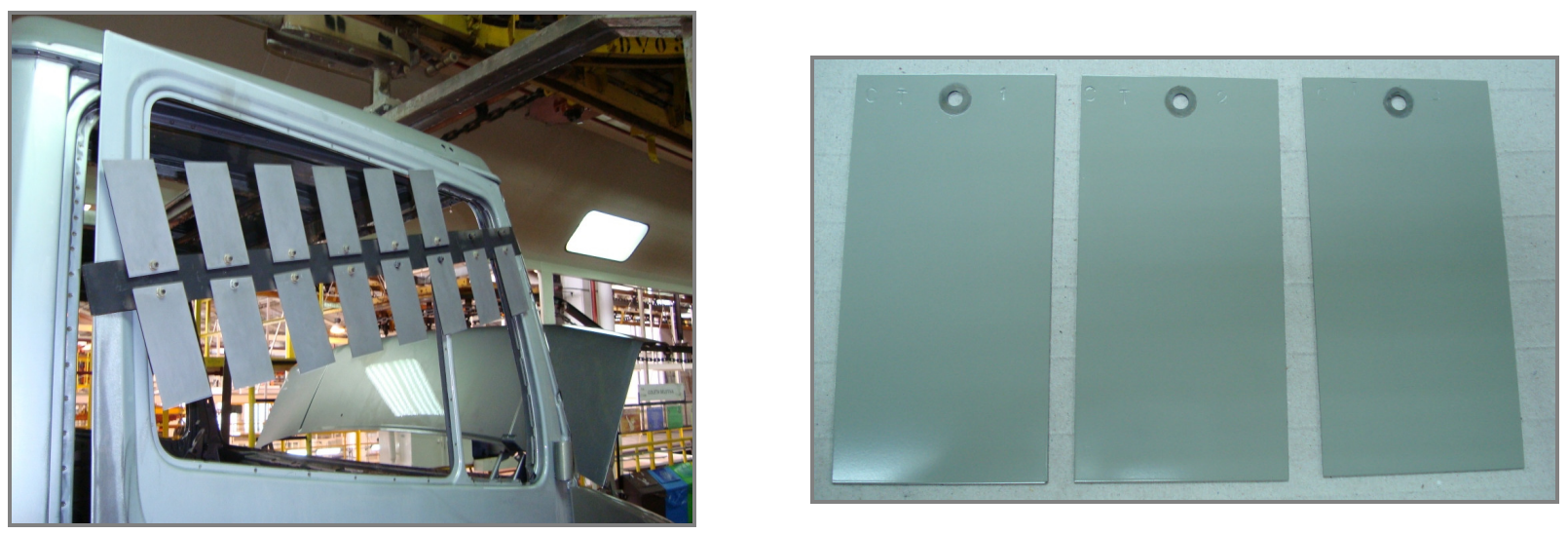

Figura 67. Placas de aço fixadas em cabine antes da pintura por imersão e revestidas com tinta eletroforética, após pintura e secagem. 
Após revestimento por tinta, as amostras foram encaminhadas para exposição em câmara de nevoa salina durante 504 horas. A avaliação visual das amostras após este período não apresentou diferenças significativas em relação aos produtos de corrosão para as camadas com fosfato tricatiônico, com exceção para as placas sem revestimento de fosfato, onde se observou o efeito da corrosão subcutânea. A proteção proporcionada pelo revestimento de fosfato ao aço, no sentido de evitar a ocorrência da corrosão subcutânea é conhecida e referenciada [50].

No ensaio de aderência observou-se descolamento da película de tinta para a amostra sem fosfato, e desempenho semelhante para as camadas com fosfato.

A Figura 68 apresenta os resultados do ensaio por névoa salina. E a Figura 69 apresenta o resultado do ensaio de aderência, realizado após exposição em névoa salina, para as placas nas mesmas condições.
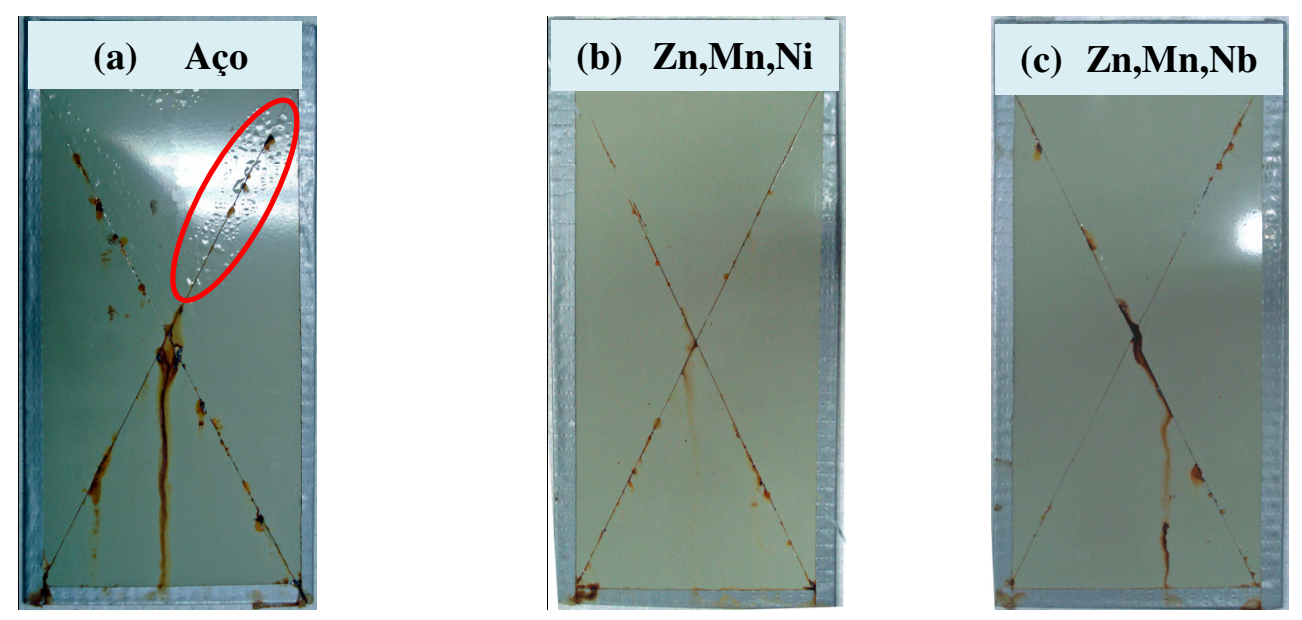

Figura 68. Placas após 504 horas em câmara de névoa salina, segundo norma ASTM B-117. (a) Aço sem revestimento, com tinta eletroforética. (b) Aço com fosfato de Zn, Mn, Ni e tinta eletroforética. (c) Aço com fosfato de Zn, Mn, Nb e tinta eletroforética. 

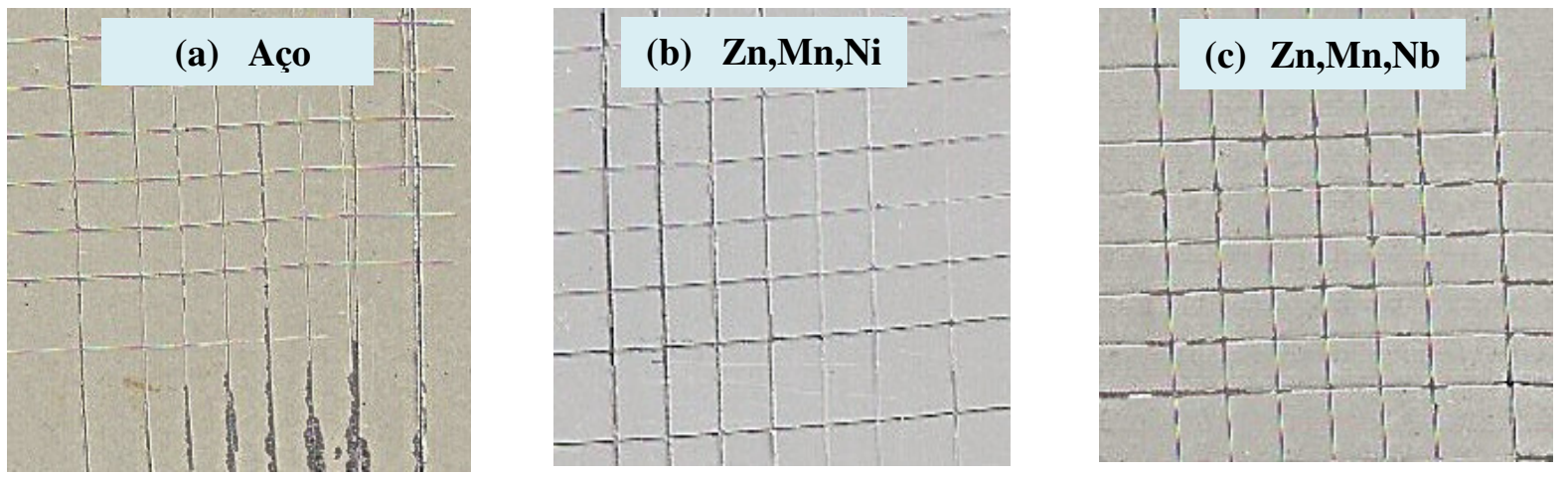

Figura 69. Resultado do ensaio de aderência, após corrosão por névoa salina, segundo norma NBR 11003/2009. (a) Aço sem revestimento, com tinta eletroforética. (b) Aço com fosfato de $\mathrm{Zn}$, Mn, Ni e tinta eletroforética. (c) Aço com fosfato de $\mathrm{Zn}, \mathrm{Mn}$, $\mathrm{Nb}$ e tinta eletroforética. 


\section{DISCUSSÃO DOS RESULTADOS}

Observando-se os resultados relativos à caracterização superficial das camadas de fosfato pelas técnicas de espectroscopia de energia dispersiva, espectroscopia por infravermelho e difração de raios-X, a troca do $\mathrm{Ni}$ pelo composto de $\mathrm{Nb}$ não apresentou alterações significativas nesses gráficos. Isto pode estar relacionado a pequenas quantidades adicionadas destes compostos e/ou a uma atuação semelhante entre eles, sendo que neste caso o composto de $\mathrm{Nb}$ estaria atuando mais efetivamente na criação de pontos de nucleação dos cristais. Esta hipótese deve-se à observação de camadas com tamanho de grãos menores (em grande parte) e maior valor de massa por área $\left(4,9\right.$ g.m $\left.\mathrm{m}^{-2}\right)$, no caso do fosfato obtido em presença de $\mathrm{Nb}$, que é quase duas vezes e meia a massa por área do fosfato com níquel (2,1 g.m ${ }^{-2}$ ) (item 8.2.1). Em apoio a estes resultados, no item 8.1.4 observa-se que para valores médios estimados das espessuras das camadas, aquela composta com composto de nióbio apresentou maior espessura $(2,6 \mu \mathrm{m})$ em relação à com níquel $(1,5 \mu \mathrm{m})$.

Além de uma atuação mais efetiva na nucleação, acredita-se que o composto de nióbio também atue durante a fosfatização passivando algumas regiões da superfície do aço. Os resultados eletroquímicos apresentados no item 8.3 indicaram redução na corrente de corrosão quando há presença do composto de nióbio em soluções, o que é um indicativo de sua propriedade de passivação. Além disso, pelas curvas de polarização anódicas (item 8.2.2), observa-se que as camadas com composto de nióbio apresentaram maior polarização que as com $\mathrm{Ni}$, indicando que nesta primeira camada as reações de corrosão foram dificultadas pela presença de um filme passivo.

Uma observação experimental relevante, que reforça a existência de filme passivo no substrato metálico, como resultado da ação do composto de nióbio durante a fosfatização, foi obtida quando o banho de fosfatização (ST617 Zn,Mn+Nb) eventualmente atingiu $58{ }^{\circ} \mathrm{C}$, onde as placas de aço ficaram imersas por 5 minutos. Como resultado, estas placas apresentaram uma cobertura de fosfato muito irregular e parte da superfície azulada (Figura 70). 
Estudos realizados durante esta pesquisa e já publicados [85], avaliaram o efeito da variação da temperatura nos banhos de fosfato (Tric $\mathrm{Zn}, \mathrm{Mn}, \mathrm{Nb}$ ), entre $40{ }^{\circ} \mathrm{C}$ e $70^{\circ} \mathrm{C}$, e mostraram que as propriedades de proteção e a morfologia das camadas de fosfato são altamente dependentes da temperatura do banho, melhorando, de maneira geral, com o aumento desta.
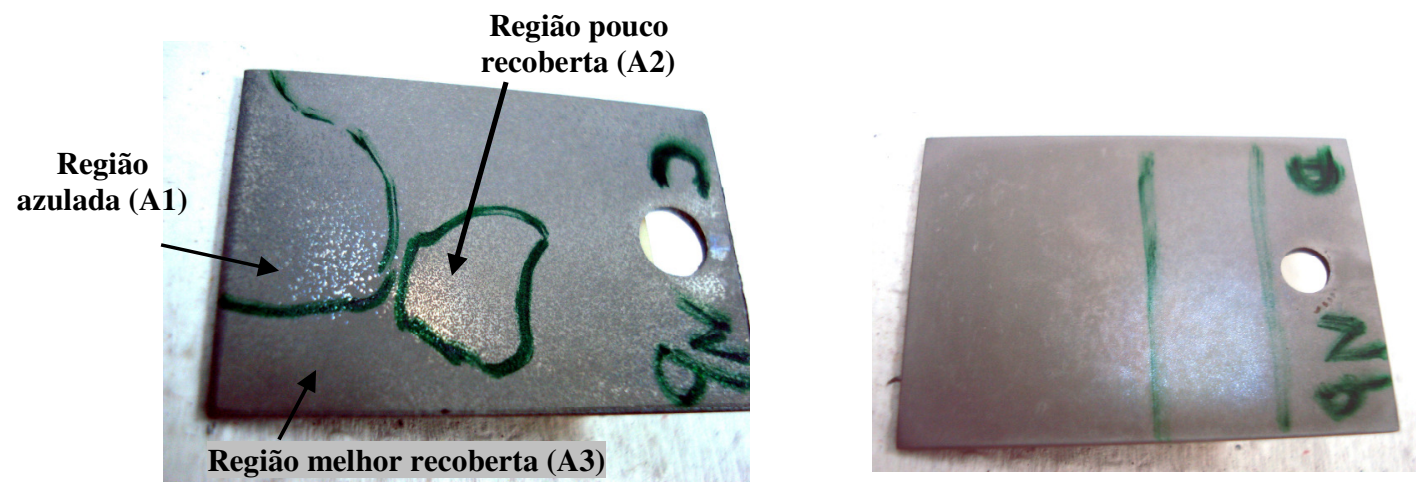

Figura 70. Amostras de aço apresentando revestimento não uniforme de fosfato de $\mathrm{Zn}, \mathrm{Mn}$ e $\mathrm{Nb}$ aplicado à $58^{\circ} \mathrm{C}$ por 5 minutos, com 1 g. $\mathrm{L}^{-1}$ de $\mathrm{NaNO}_{2}$.

As análises por MEV e EDS (Figuras 71 e 72) mostraram que nestas áreas a camada de fosfato apresentou morfologia completamente modificada em relação às micrografias anteriores (Figura 50). Na composição semiquantitativa da região azulada (A1) é observado menos $\mathrm{O}, \mathrm{Zn}$ e $\mathrm{P}$ que o encontrado na região bem recoberta (A3), indicando menos fosfato (Figura 72).

Na Figura 71, a imagem "A2" é um exemplo do que ocorre na superfície do aço durante a fosfatização quando não há uma nucleação adequada. Os cristais formados crescem bastante por não haver outros muito próximos. Nas imagens A1 e A3 desta mesma figura também são observados cristais de tamanhos e formas diferentes, dentro das mesmas regiões analisadas, resultado de uma atuação diferenciada do composto de nióbio na superfície. 

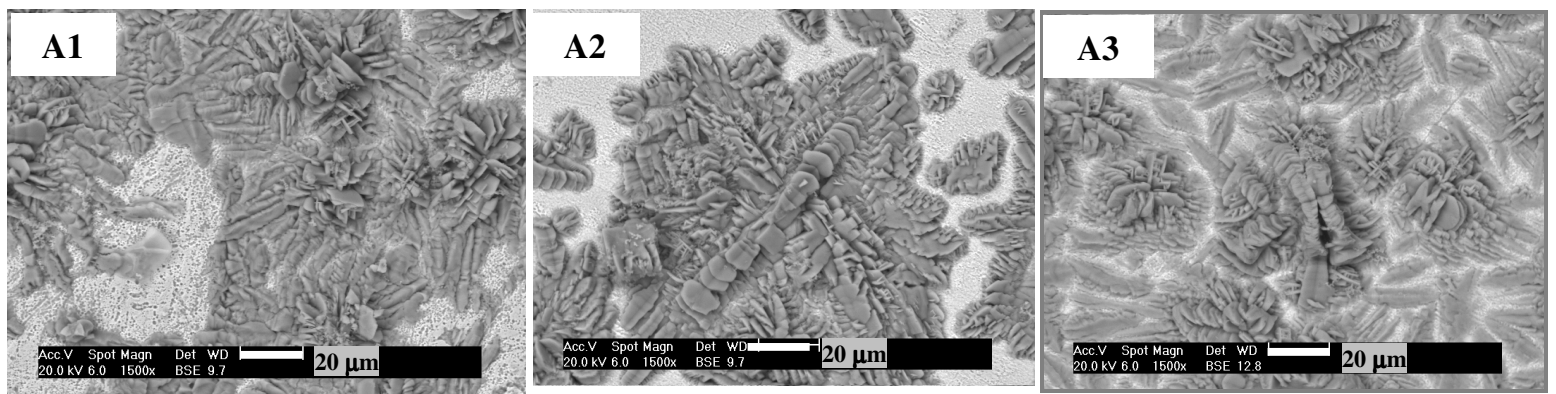

Figura 71. Micrografias por MEV (imagens por elétrons retroespalhados) de camada de fosfato de $\mathrm{Zn}$, Mn e $\mathrm{Nb}$, obtida por 5 minutos de imersão a $58^{\circ} \mathrm{C}$, apresentando 3 regiões distintas, referenciadas na Figura 70. A1) região azulada. A2) região pouco recoberta. A3) região melhor recoberta.
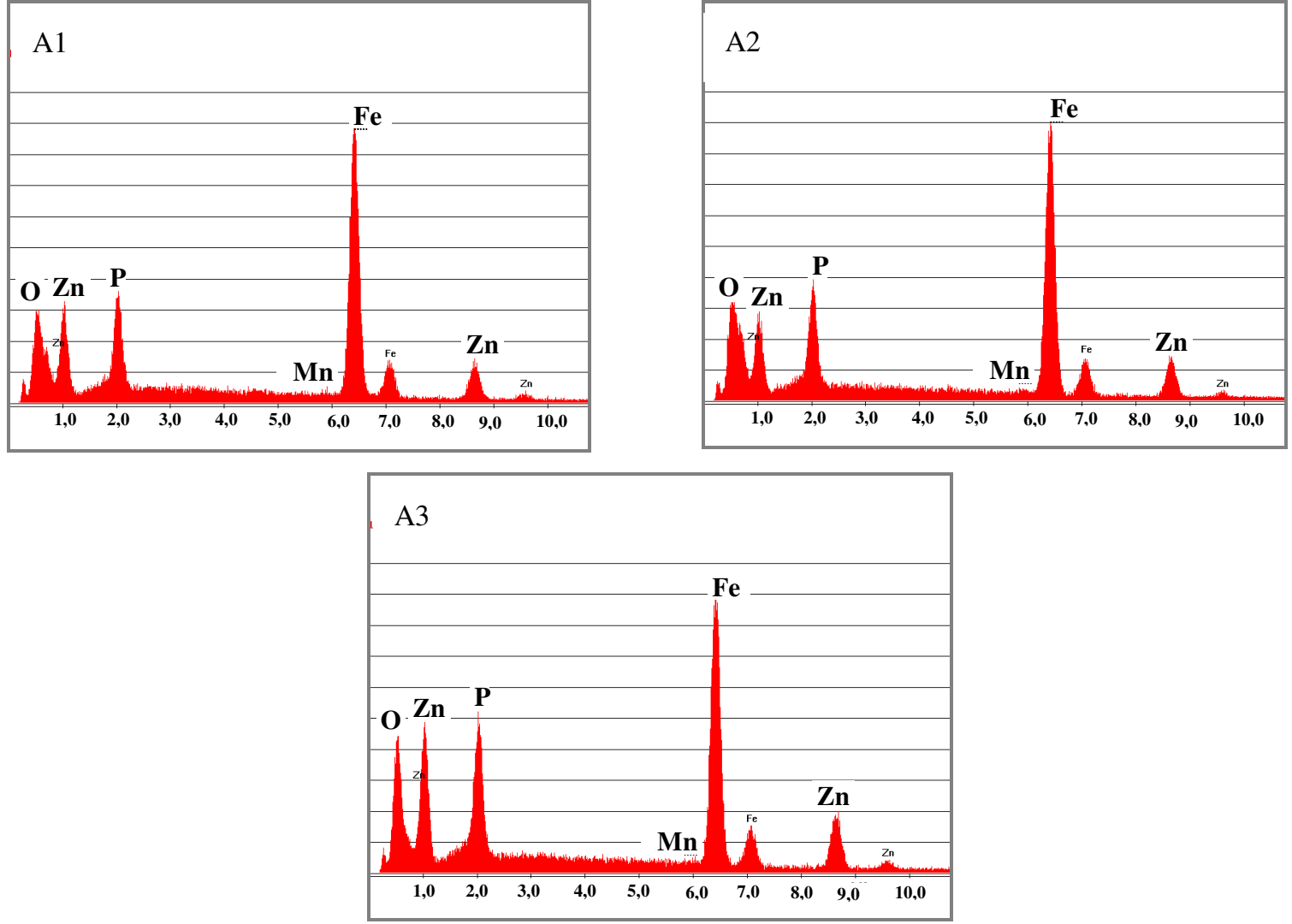

Figura 72. Espectros obtidos por EDS de camada de fosfato de $\mathrm{Zn}$, Mn e Nb obtida por 5 minutos de imersão a $58^{\circ} \mathrm{C}$, das 3 regiões distintas referenciadas na Figura 70. A1) região azulada. A2) região pouco recoberta. A3) região melhor recoberta. 


\subsection{Proposta de Mecanismo para Atuação do Oxalato de Nióbio e Amônio durante Fosfatização do Aço Carbono}

Acredita-se que o aumento da temperatura do banho de fosfatização durante a imersão da placa de aço, a $58{ }^{\circ} \mathrm{C}$, resultou concomitantemente na fosfatização e passivação superficial de parte do substrato exposto dessa amostra, como proposta apresentada na Figura 73. Esta hipótese propõe uma atuação dupla do composto de nióbio quando adicionado aos banhos de fosfatização, que resulta em maior proteção superficial das placas fosfatizadas com composto de nióbio em relação ao níquel.

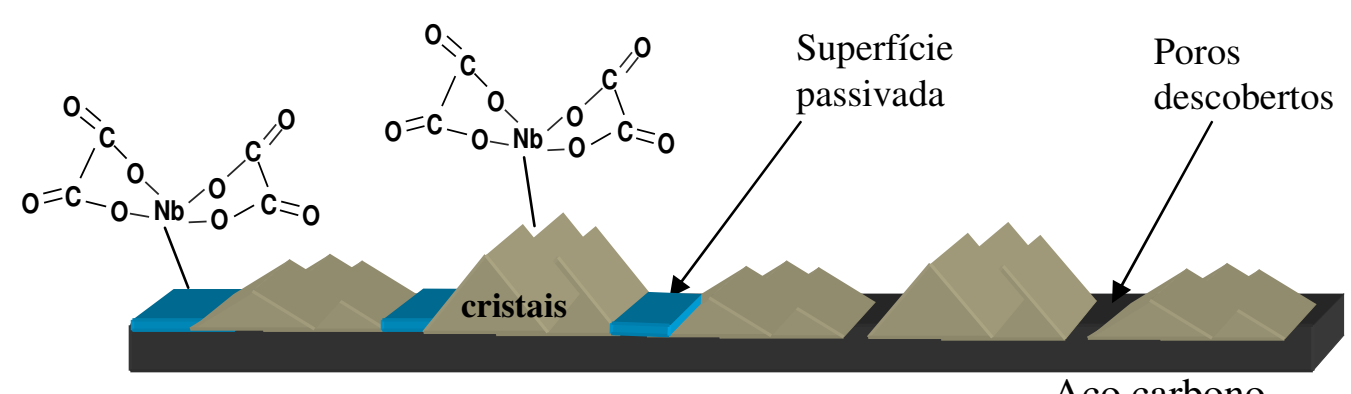

Aço carbono

Figura 73. Representação esquemática de proposta para atuação do oxalato de nióbio e amônio em banho de fosfatização tricatiônico, tanto na nucleação de cristais como na passivação superficial de áreas do substrato metálico exposto.

Acredita-se que para uma mesma microrregião, o composto de nióbio atue nucleando cristais e passivando a superfície metálica. Desta maneira, quando sua atuação for mais efetiva na nucleação de cristais, o resultado observado é uma cobertura cristalina homogênea, com tamanho de cristais semelhantes; porém quando sua atuação for mais efetiva na passivação superficial, o que se observa é a formação de cristais com maior tamanho e com forma diferenciada. Este foi o resultado observado por MEV para as camadas otimizadas de fosfato tricatiônico contendo o oxalato de nióbio e amônio, na concentração de 5 ppm de nióbio (Figuras 36 e 50). Eventualmente, a passivação da superfície metálica impede a formação da camada de fosfato em algumas áreas. 
Análises por XPS (Espectroscopia de Fotoelétrons por Raios-X) deste filme de passivação sobre superfícies de aço galvanizado [86] indicaram em sua composição uma concentração de carbono muito superior que a de $\mathrm{Nb}$ em sua forma estável $\left(\mathrm{Nb}_{2} \mathrm{O}_{5}\right)$.

Considerando que nos banhos de fosfatização não ocorra a polimerização e precipitação do $\mathrm{Nb}_{2} \mathrm{O}_{5}$ [63], devido ao baixo $\mathrm{pH}$ das soluções de fosfatização $(\mathrm{pH}<4,0)$, é provável que o oxalato tenha presença relevante na composição deste filme passivo. 


\section{CONCLUSÕES}

$>$ A substituição do níquel por composto de nióbio em banhos de fosfato tricatiônico é vantajosa do ponto de vista de resistência à corrosão. Os resultados eletroquímicos de polarização potenciodinâmica e de espectroscopia de impedância eletroquímica foram relevantes na avaliação final dos resultados e indicaram maior proteção à corrosão para aço fosfatizado em presença de composto de nióbio.

A observação da superfície por MEV, para o fosfato obtido no banho de $\mathrm{Zn}, \mathrm{Mn}$ e $\mathrm{Nb}$ à $50{ }^{\circ} \mathrm{C}$ por 5 minutos, com adição de 1 g. $\mathrm{L}^{-1}$ de $\mathrm{NaNO}_{2}$, apresentou uma boa cobertura superficial do substrato.

A morfologia da camada de fosfato obtida em presença do composto de nióbio foi significativamente modificada em relação à camada formada em banho contendo níquel. Os cristais da primeira apresentaram-se menos angulosos em comparação à segunda, além de indicarem maior cobertura do substrato metálico.

A presença do composto de nióbio no banho de fosfatização leva a formação de camadas de fosfato com maior valor de massa por área $\left(\mathrm{g} \cdot \mathrm{m}^{-2}\right)$ e espessura em comparação à obtida em solução com níquel.

- Os resultados sugeriram que o composto de nióbio atua na superfície do aço de maneira semelhante ao níquel, aumentando os pontos de nucleação do fosfato na fosfatização; porém, ao mesmo tempo atuando na passivação do substrato metálico exposto na base dos poros. Também que pode ser viável seu uso como passivador em substituição ao $\mathrm{CrO}_{3}$, sendo porém interessante uma maior investigação.

> Os ensaios em névoa salina e aderência não mostraram diferenças significativas entre a camada de fosfato obtida em presença do composto de $\mathrm{Nb}$ e aquela formada em presença de Ni.

$>$ Os resultados mostraram que pode ser viável a troca do níquel pelo composto de nióbio em banhos de fosfato tricatiônico. 


\section{PROPOSIÇÃO DE TEMAS PARA PESQUISAS FUTURAS}

Estudo da relação entre a área de aço exposta e o volume do banho de fosfatização;

Estudo da passivação pelo oxalato de nióbio e amônio de placas fosfatizadas, em soluções não tamponadas;

$>$ Estudo de filmes passivos formados pelo oxalato de nióbio e amônio em aço carbono e/ou aço galvanizado e caracterização desses filmes;

Estudo da camada composta por zinco, manganês e nióbio em aços galvanizados;

$>$ Otimização da concentração do acelerador $\mathrm{NaNO}_{2}$ para fosfatização tricatiônica de $\mathrm{Zn}$, $\mathrm{Mn}$ e Nb;

Investigação de alternativas para substituição do acelerador de nitrito por outros sem restrições ambientais;

Estudo da porosidade de camadas de fosfato, com e sem tratamentos de passivação. 
ANEXO A

LAUDOS DA ANÁLISE DO AÇO 1005 


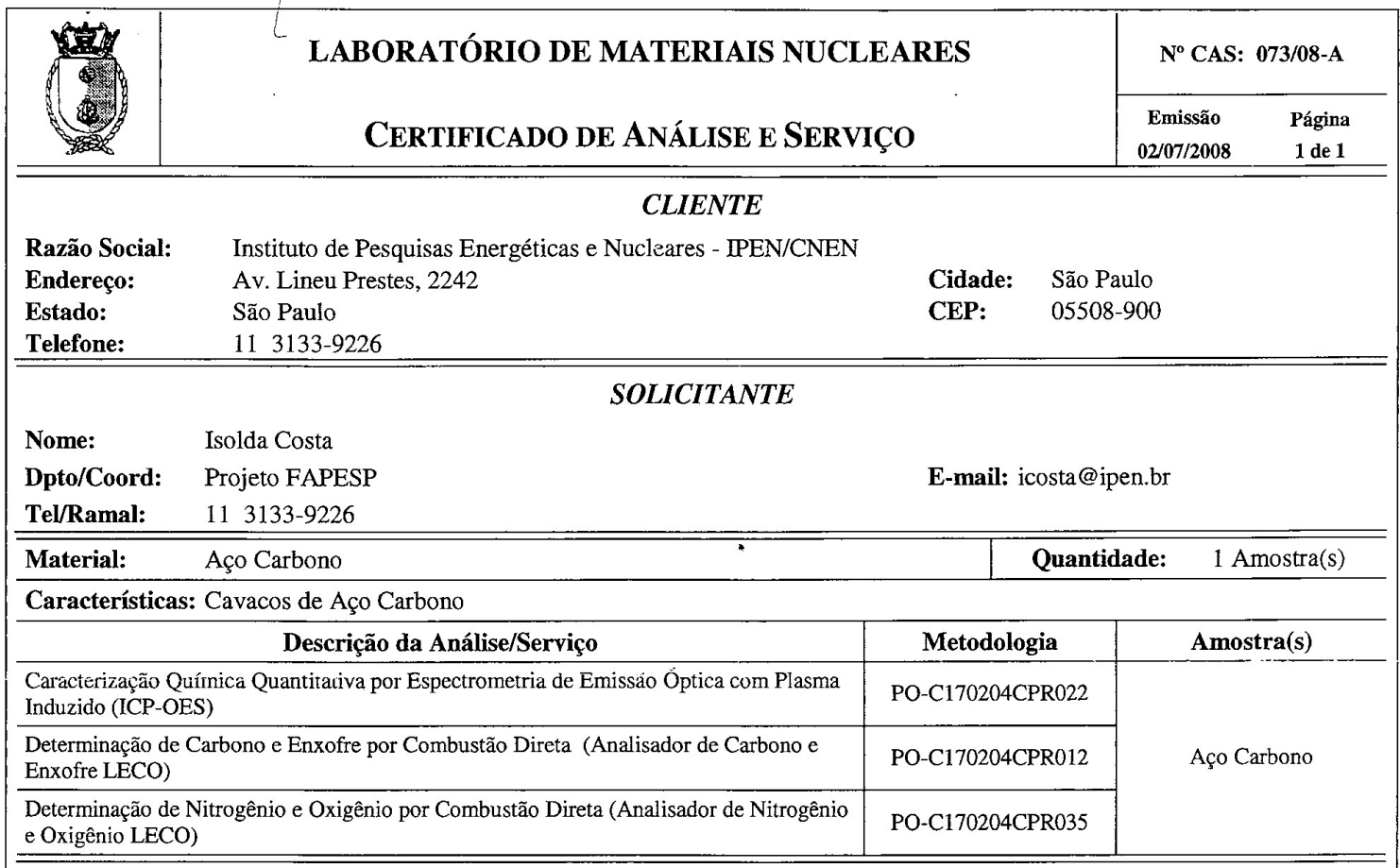

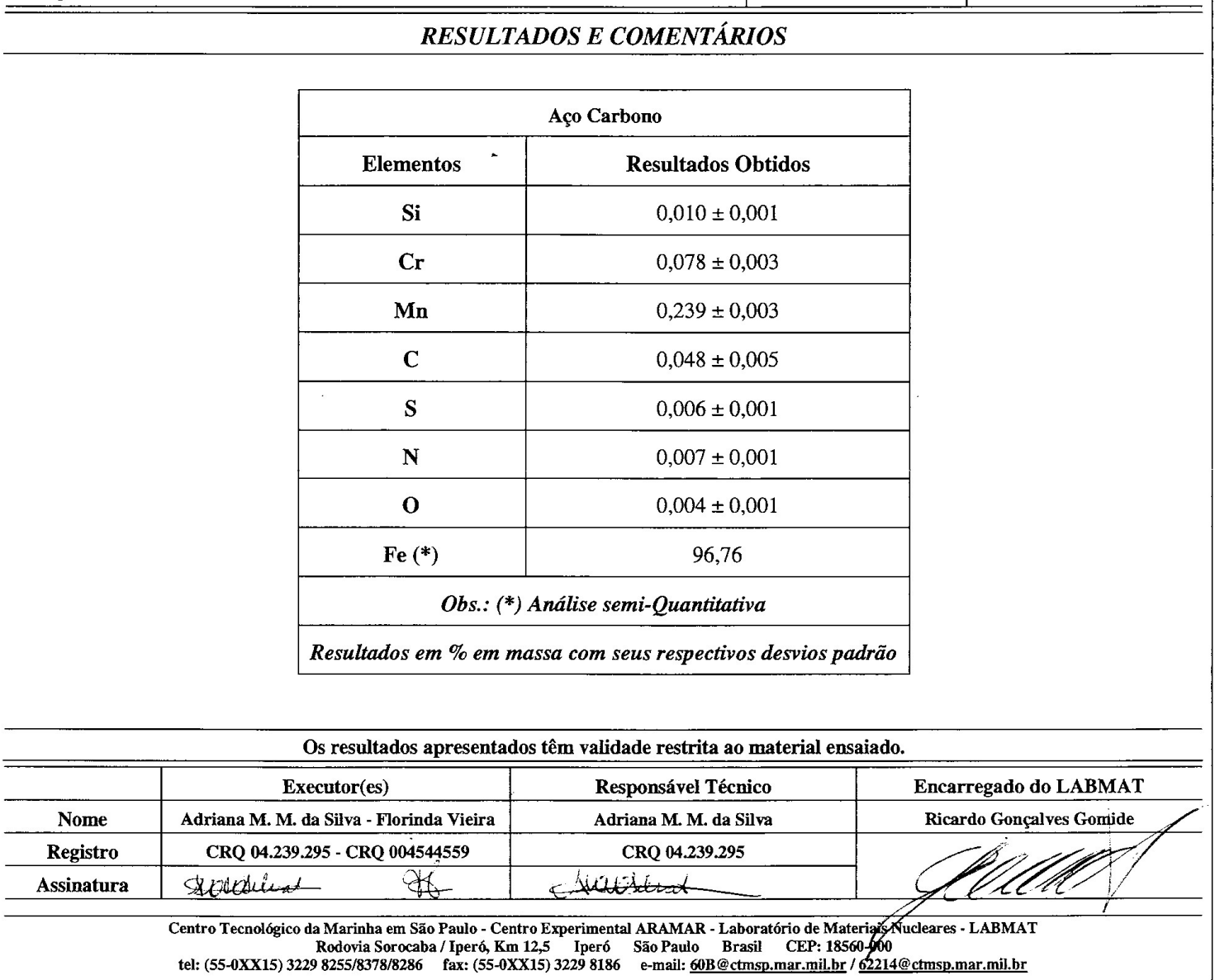




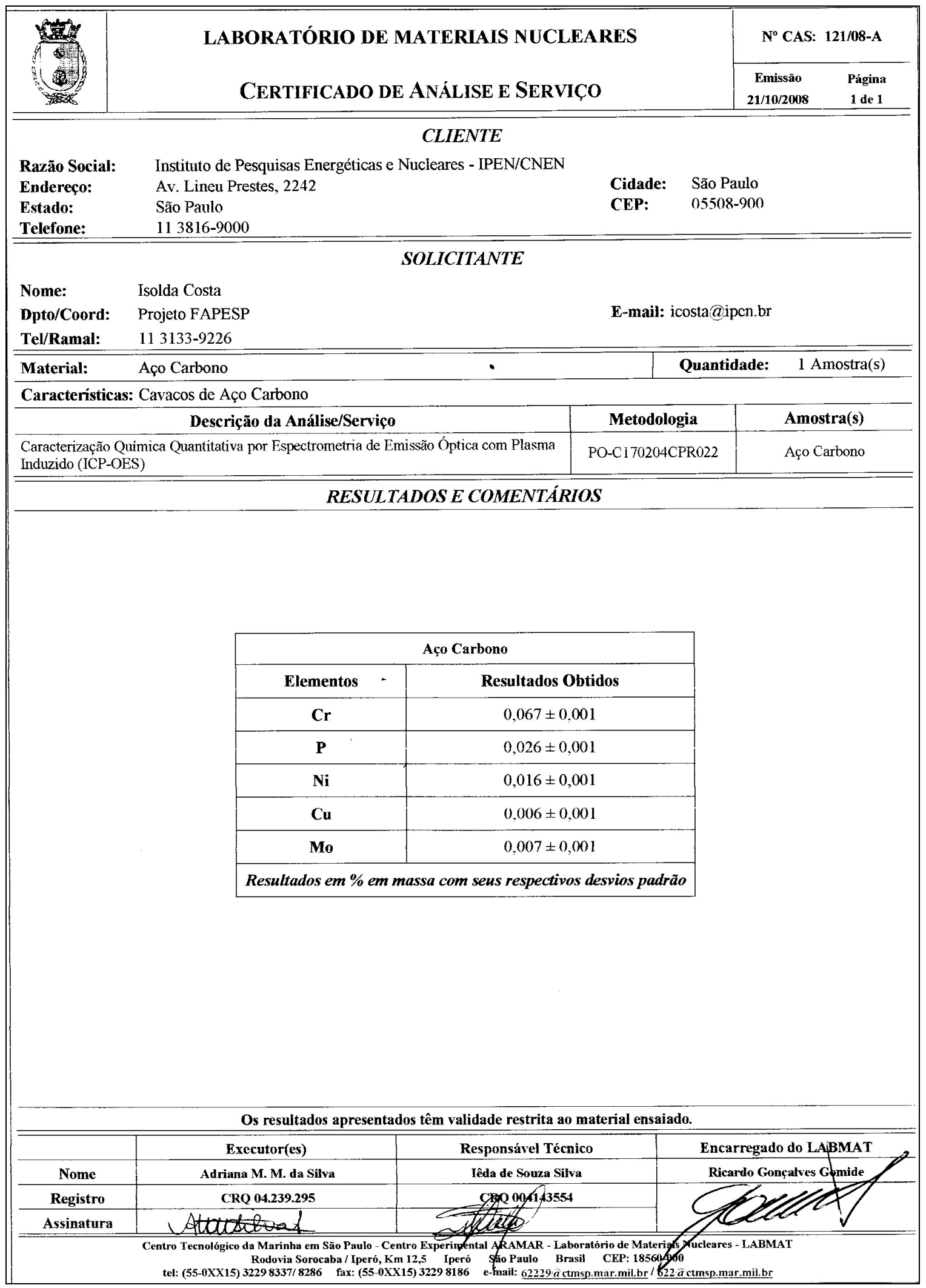


ANEXO B

PROJETO DA LINHA PILOTO DE FOSFATIZAÇÃO 


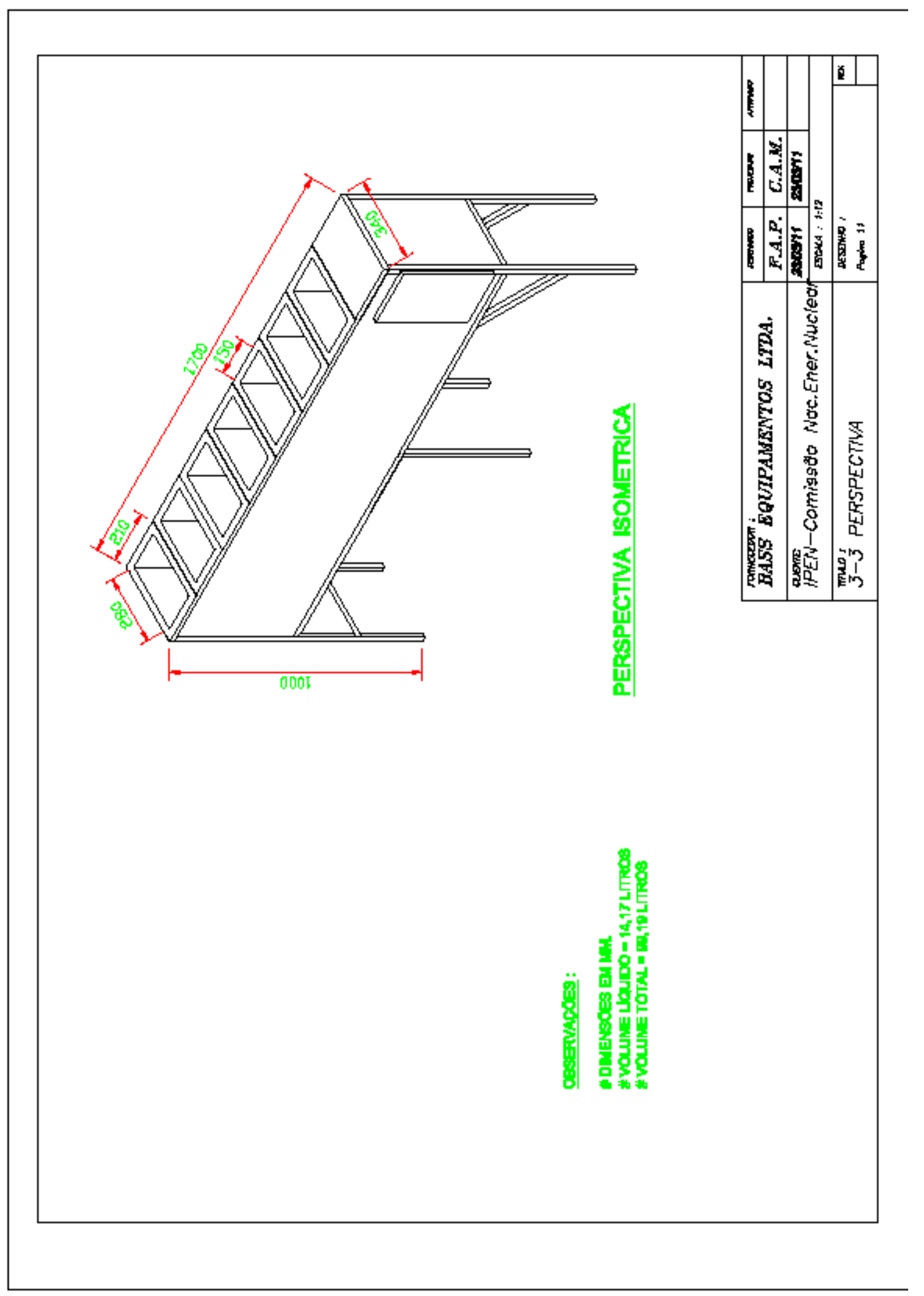




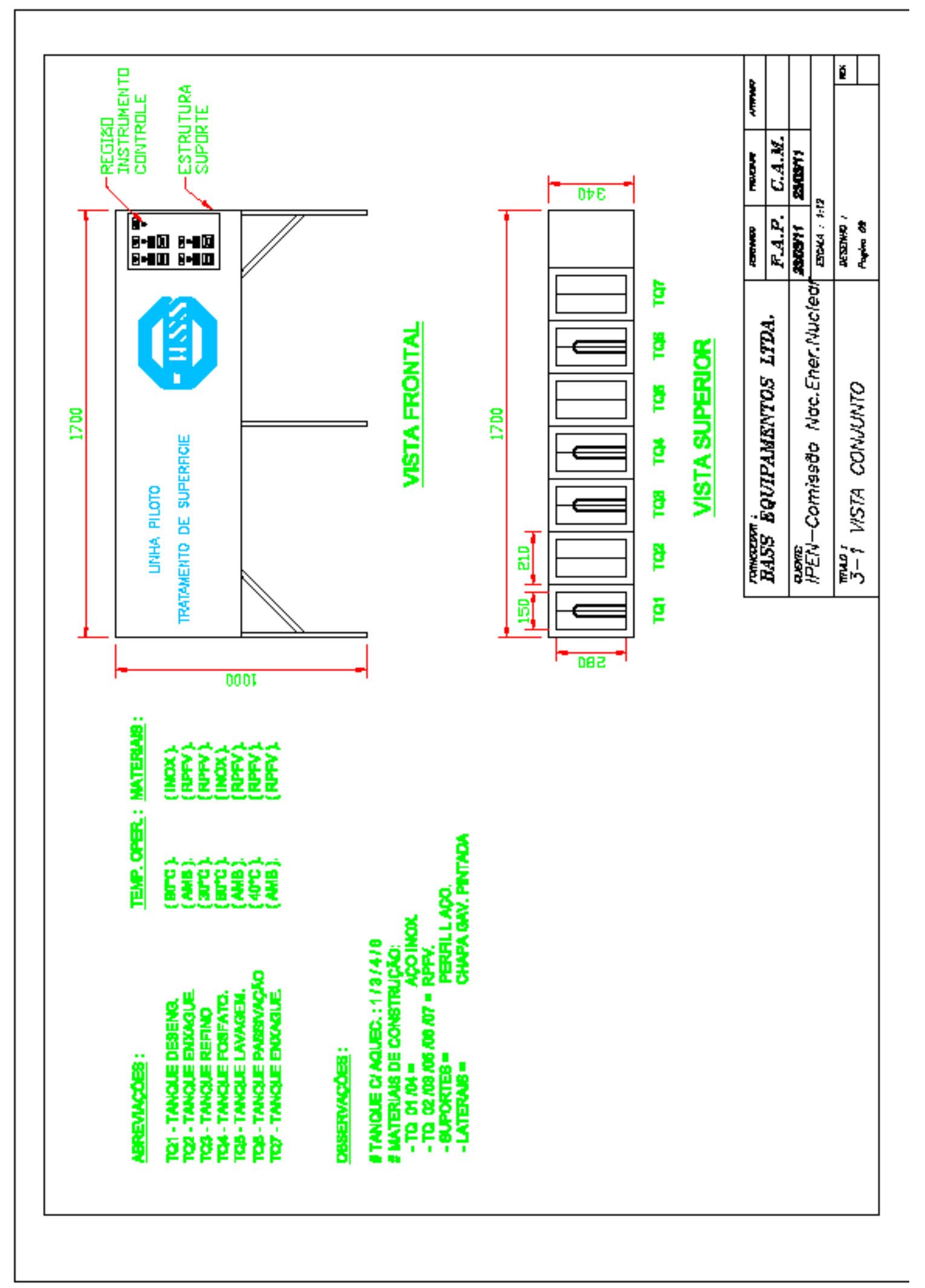




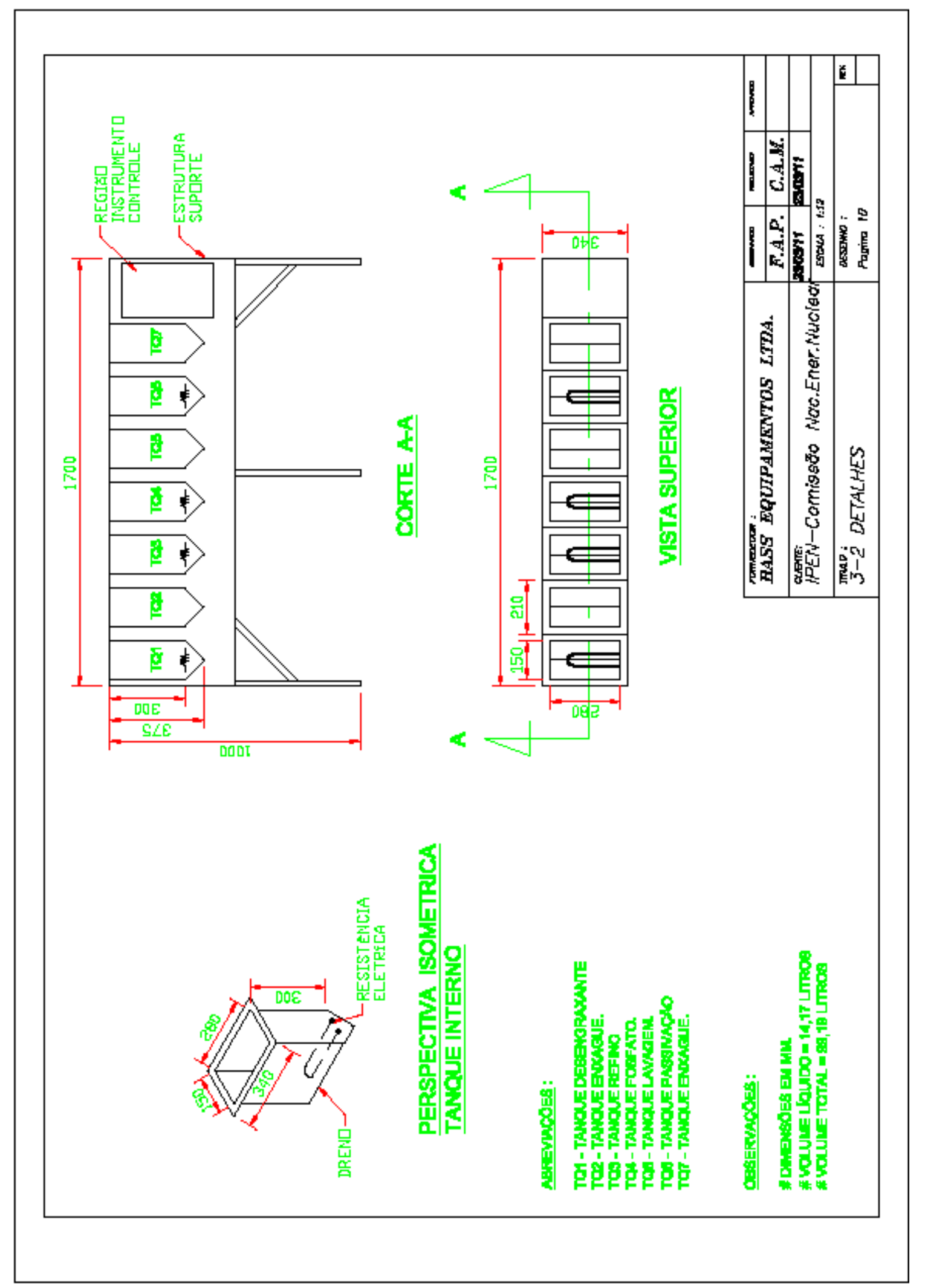




\section{REFERÊNCIAS BIBLIOGRÁFICAS}

1 H.J.A. BREUR, J.H.W. de Wit b, J. van Turnhout c, G.M. Ferrari. Electrochemical impedance study on the formation of biological iron phosphate layers. Electrochimica Acta 47 (2002) 2289-2295.

2 BANCZEK, E. P. Desenvolvimento e Caracterização de Camadas de Fosfato de Zinco/Níquel e Zinco/Nióbio. 2008. Tese de Doutorado. IPEN - Instituto de Pesquisas Energéticas e Nucleares, autarquia associada a USP. 2008.

3 Occupational Health Guideline for Nickel Metal and Soluble Nickel Compounds. Disponível em: <http://www.cdc.gov/niosh/docs/81-123/pdfs/0445.pdf>. Acesso em: setembro de 2011.

4 Evaluation of Carcinogenic Risks To Humans - Chromium, Nickel and Welding. International Agency for Research on Cancer . World Health Organization. IARC Monographs, vol. 49. IARC Lion / France. 1990.

5 Nickel Compounds. U.S. Environmental Protection Agency. Disponível em: <http://www.epa.gov/ttn/atw/hlthef/nickel.html>. Acesso em: outubro de 2009

6 Variáveis de Qualidade das águas. Disponível em: $<$ http://www.cetesb.sp.gov.br/agua/aguas-superficiais/34-variaveis-de-qualidade-dasaguas-old\#niquel>. Acesso em: setembro de 2011.

7 Contact Dermatitis. Disponível em: <http://health.allrefer.com/health/contactdermatitis-dermatitis-nickel-on-the-sole.html>. Acesso em: outubro de 2009

8 Hexavalent Chromium. National Institute for Occupational Safety and Health NIOSH. Disponível em: <http://www.cdc.gov/niosh/topics/hexchrom/>. Acesso em: outubro de 2009

9 GENTIL, V. Corrosão. LTC - Livros Técnicos e Científicos Editora S.A. $3^{\text {a }}$. Edição 1996. Rio de Janeiro/RJ.

10 LANA, C. R. Corrosão, Polímeros Sintéticos e Baterias - Química do Automóvel (4). Em: http://educacao.uol.com.br/quimica/ult1707u68.jhtm. Acesso em 2010. 
$11 \mathrm{KOCH}, \mathrm{G}$. H. et al. Corrosion Costs and Preventive Strategies in the United States. Publication No. FHWA-RD-01-156. US Department of Transportation. Federal Highway Administration. Nace International. 2002 USA.

12 GUERreiro, M. A. V. Avaliação de Processo de Fosfatização. Trabalho de Diplomação ENG 02298. Universidade Federal do Rio Grande do Sul, novembro, 2009.

13 COELHO, J. F. P. Palestra Nova ABRACO. In: http://www.abraco.org.br/NAbracoP/slide0.htm\#MARCA. Acesso em 2010.

14 FERnÁndeZ, A. C. La Fosfatación. Tratamiento Anticorrosivo. Base adherente para lãs pinturas. Para la deformación em frio de los metales. Mejora la lubricación em condiciones serveras. Editor José Oriol Ávila Montesó. Barcelona,1962.

15 SOUZA JR, O. B. A Nanotecnologia Aplicada a Prevenção da Corrosão: O Uso de Nanocerâmicos de Alumina e Zircônia. Dissertação (Mestrado). Universidade Estadual de Londrina, Londrina - 2008.

16 ZEMPULSKI, L. N.; ZEMPULSKI, M. F. S. Fosfatização. Dossiê Técnico do Instituto de Tecnologia do Paraná - TECPAR. Agosto, 2007.

17 FERREIRA FILHO, A. Tiras de aço relaminadas a frio e fosfatizadas aplicadas em processos de estampagem - Parte 1. Siderurgia Brasil Edição 51.

18 PANOSSIAN, Z.; SANTOS, C. A. L. Fosfatização de Metais Ferrosos. Parte 1 Histórico. In: Corrosão\&Proteção. Maio/junho de 2006. Págs. 22-23

19 NARAYANAN, Sankara. Surface Pretreatement by Phosphate Conversion Coating - A Review. Rev.Adv.Mater.Sci. 9 (2005) 130-177.

20 SHREIR, L. L. Corrosion Control. Corrosion, volume 2. John Wiley \& Sons, INC. New York. 1963.

21 RAMANATHAN, V. L. Corrosão e Seu Controle. Hemus Editora Ltda. São Paulo.

22 RAUSCH, W. The Phosphating of Metals. ASM International. Metals Park, Ohio, USA. Finishing Publications Ltd, Teddington, Middlesex, England. 1990. 
23 OGLE, K.; WOLPERS, M. Phosphation Conversion Coatings. Corrosion: Fundamentals, Testing, and Protection. ASM Handbook, ASM International, 2003, Vol. 13A, p. 712-719.

24 CAPE, Thomas W. Chemfill Corporation. Phosphate Conversion Coatings. ASM Handbook. 1992. Vol. 13, p. 869-881.

25 BRITISH STANDARDS. Phosphate conversion coatings of metals. Method of specifying requirements. BS EN 12476:2000.

26 International Organization for Standardization. Phosphate conversion coatings for metals - Method of specifying requirements. ISO 9717:1990.

27 ZIMMERMANN, D.; MUÑOZ, A.G.; SCHULTZE, J.W. Formation of Zn-Ni alloys in the phosphating of Zn layers. Surface and Coatings Technology 197 (2005), p. $260-269$.

28 KLUSMANN, E.; SCHULTZE, J. W. pH-Microscopy: technical application in phosphating solutions. Electrochimica Acta 48 (2003), p. 3325-3332.

29 SCHULTZE, J.W., MULLER, N., Metalloberflache 53 (1999) 17, apud Zimmermann, D., Munõz, A.G., Schultze, J.W. Microscopic local elements in the phosphating process. Electrochimica Acta 48 (2003) 3267-3277.

30 PANOSSIAN, Z., SANTOS, C. A. L. Fosfatização de metais ferrosos. Parte 5 Mecanismos de Fosfatização. Corrosão e Proteção, Janeiro/Fevereiro, 2007. Págs. 24-26.

31 GHAli, E. L. and POTVIN, R. J. A. The Mechanism of Phosphating of Steel. Corrosion Science, 1972, Vol. 12, p. 583 - 594.

32 NEUHAUS, A. and GEBHARDT, M. Werkstoff und Korrosion 17 (1966) 493. Apud NARAYANAN, Sankara. Surface Pretreatement by Phosphate Conversion Coating - A Review. Rev.Adv.Mater.Sci. 9 (2005) 130-177.

33 Dados do Mineral fosfofilita e hopeita. Em: http://webmineral.com/data/Hopeite.shtml; http://www.webmineral.com/data/Phosphophyllite.shtml. Acesso em 2010. 
34 PANOSSIAN, Z; SANTOS, C. A. L. Propriedades das camadas fosfatizadas. Corrosão e Proteção. Ano 7, No. 35. Novembro/dezembro 2010. São Paulo-SP.

35 FEDRIZZI, L.; DEFLORIAN, F.; ROSSI, S.; FAMBRI, L.; BONORA, P.L. Study of the corrosion behavior of phosphatized and painted industrial water heaters. Progress in Organic Coating 42 (2001) 65-74.

36 MIYAWAKI, T., OKITA, H., UMEHARA, S. and OKABE, M., In: Proceedings of the conference on Interfinish 80 (Kyoto, 1980). Apud NARAYANAN, Sankara. Surface Pretreatement by Phosphate Conversion Coating - A Review. Rev.Adv.Mater.Sci. 9 (2005) 130-177.

37 RICHARDSON, M.O.W., FREEMAN, D.B., BROWN, K. and DJAROUD, N. Influence of zinc phosphate crystalline morphology on the corrosion resistance of electropainted steel. Technical Papers, Annual Technical Conference and Exhibition - Institute of Metal Finishing, 3, pp. 35-53.

38 NARAYANAN, S. T. S. N. and SUBBAIYAN, M. Effect of Surfactants on the Porosity and Corrosion Resistance of Zinc-Phosphated Steel. Metal Finishing, August, 1993, pp. 43-45.

39 FERNANDES, K. S.; ALVARENGA, E. A.; BRANDÃO, P. R. G.; LINS, V. F. C. Análise por espectroscopia no infravermelho das camadas de fosfato de zinco e de zinco modificado com níquel e manganês em aço eletrogalvanizado. REM: R. Esc. Minas, Ouro Preto, 64(1), 045-049, janeiro/março, 2011. Metalurgia e Materiais.

40 BIESTEK, T. and WEBER, J. Electrolytic and chemical conversion coatings. $1^{\text {st }}$ ed. Wydawnictwa: Portecceilles, 432p. 1976. Apud PANOSSIAN, Z. and SANTOS, C. L. Fosfatização de metais ferrosos. Parte 11- Aceleradores: Sais metálicos e outros. Corrosão e Proteção, Janeiro/fevereiro, 2008.

41 MUÑOZ, A.G.; SCHLTZE, J. W. Effects of $\mathrm{NO}_{2}-$ on the corrosion of $\mathrm{Ni}$ in phosphate solutions. Electrochimica Acta 49 (2004) p. 293-301.

42 An Introduction to Indoor Air Quality (IAQ) - Nitrogen Dioxide ( $\left.\mathbf{N O}_{2}\right)$. http://www.epa.gov/iaq/no2.html. Acesso em 17/10/11. 
43 NARAYANAN, S. Influence of various factors on phosphatability - an overview. Metal finishing. v.94, n. 6, p.86-90, june. 1996.

44 Zimmermann D.; Munoz A.G.; Schultze J.W. Elementos Microscópicos Locais no Processo de Fosfatização. Electrochimica Acta, Volume 48, Número 20, 30 Setembro, 2003, p. 3267-3277(11). Elsevier.

<http://www.galvano.com.br/fosfatizacao/fosfatizacao.htm>. Acesso em outubro de 2009.

46 KLUSMANN, E.; KÖNIG, U., SCHULTZE, J. W. Electrochemical characterization of phosphate layers on zinc coated steel. Materials and Corrosion Volume 46, Issue 2, pag. 83-91, Fevereiro, 1995.

47 GNECCO, C., MARIANO, R., FERNANDES F. Tratamento de Superfície e Pintura. Série Manual de Construção em Aço. Rio de Janeiro: IBS/SBCA 2003. 94 p.

48 TOMANDL, A., WOLPERS, M., OGLE, K. The alkaline stability of phosphate coatings II: in situ Raman spectroscopy. Corrosion Science. Volume 46, Issue 4, Abril, 2004, Págs. 997-1011.

49 OGLE, K., TOMANDL, A., MEDDAHI, N., WOLPERS, M. The alkaline stability of phosphate coatings. I: ICP atomic emission spectroelectrochemistry. Corrosion Science 46 (2004) 979-995.

50 RAUSCH, W. The Phosphating of Metals. Finishing Publications Ltd., England,1990.

51 BRITISH STANDARDS. Specification for phosphate treatment of iron and steel. BS 3189:1973.

52 REIS, F. M., BARITS, R. A fosfatização. Chemettal. s.d.

53 PANOSSIAN, Z.; SANTOS, C. A. L. Fosfatização de Metais Ferrosos. Parte 13 - Os Estágios de um processo de fosfatização. In: Corrosão\&Proteção. Maio/junho de 2008. Págs. 23-24.

54 ASSOCIAÇÃO BRASILEIRA DE NORMAS TÉCNICAS - ABNT. Resíduos Sólidos - Classificação. NBR 10004:2004. 
55 GIFFONI, P. O.; LANGE, L.C. A Utilização de Borra de Fosfato como MatériaPrima Alternativa para a Fabricação de Tijolos. Engenharia Sanitária e Ambiental, v.10, n.2, p.128-136, abril-junho, 2005.

56 ATALFIN, V. L. et all. Utilização de Lodo de Fosfatização na Produção de Mudas de Espécies Nativas. Engenharia Ambiental, Espírito Santo do Pinhal, v.1, n.1, p.4550, jan./dez., 2004.

57 DE BEM, P. P. T. Minimização do Efluente Gerado em Pré-Tratamento de Pintura Automotiva: Um Caso Industrial. Dissertação (Mestrado) - Universidade Federal do Paraná, Setor de Tecnologia, Programa de Pós-Graduação em Engenharia Mecânica, 2008.

58 DIRECTIVA 2000/53/CE DO PARLAMENTO EUROPEU E DO CONSELHO. Relativa aos veículos em fim de vida. De 18 de Setembro de 2000. Jornal Oficial das Comunidades Européias, 21.10.2000. L 269/34 PT.

59 PETSCHEL, M. Pollution Prevention and Conversion Coating in the Automobile Industry. Metal Finishing. 26-29. Setembro, 1996.

60 SILVA, C. S. Nióbio. Balanço Mineral Brasileiro. Disponível em: http://www.dnpm.gov.br/assets/galeriadocumento/balancomineral2001/niobio.pdf. Acesso em: outubro de 2009.

61 BORDignON, P.; CARNEIRO, T., TAGUSAGAWA, S., HULKA, K. História do nióbio e, Uso e usuários finais do nióbio. Disponível em: <http://www.cbmm.com.br/portug/index.html>. Acessado em: outubro de 2009.

62 BUCKLEY, R. W. Progress in Solid State Chemistry Research. Precursors routes for the preparation of Nb-based multimetallic oxides, pp. 119-120. Nova Science Publishers, New York. 2007.

63 PEREIRA, A. T.; OLIVEIRA, K. A.; MONTEIRO, R. S. Processo de produção de oxalato amoniacal de nióbio, oxalato amoniacal de nióbio e uso do mesmo. Companhia Brasileira de Metalurgia e Mineração, Araxá/MG. Patente Número PI 0403891-6 de 15/09/2004. 
64 TICIANELLI, E. A.; GONZALEZ, E. R. Eletroquímica, princípios e aplicações. $2^{\text {a }}$ ed. São Paulo. Editora da Universidade de São Paulo, 2005.

65 American Society for Testing and Materials. Prática Padrão para Avaliar o Grau de Ferrugem em Superfícies de Aço Pintado. ASTM D610/08, versão original de 1941.

66 MACHU, W., Die Phosphatierung. Frankfurt Verlog Chimie 1950. 306 p.

67 SPRING, S., Preparation of Metals for Painting (Reinhold Publishing Corporation, New York, 1965). Apud NARAYANAN, Sankara. Surface Pretreatement by Phosphate Conversion Coating - A Review. Rev.Adv.Mater.Sci. 9 (2005) 130-177.

68 MAEDA, S.; YAMAMOTO, M. The role of chromate treatment after phosphating in paint adhesion. Progress in Organic Coatings. Volume 33, Issue 1, 30 January 1998, Pages 83-89.

69 POLEDNA, S. R. C. EEP SENAI. SENAI-RS/Departamento Regional.15/06/2005. Palavras chave: Eletrolítica; galvanização; processo. Disponível em: http://www.sbrt.ibict.br, acessar: http://www.respostatecnica.org.br/acessoRT/889 .

70 ALMEIDA, M.E.M. Guia sobre proteção anticorrosiva na indústria automobilística, Protap, 2000. Apud TETTO DE BEM, P. P. Minimização do efluente gerado em pré-tratamento de pintura automotiva: um caso industrial. Dissertação de Mestrado, Universidade Federal do Paraná, Curitiba, 2008.

71 BARD, A. J. Encyclopedia of electrochemistry of the elements. Editor: Allen J. Bard. New York. M. Dekker, 1973.

72 QUElHAS, K.A.S. Estudo da Corrosão do Nióbio em Meio Metanólico. Tese (doutorado) Engenharia Metalúrgica e de Materiais, 2007) Tese - Universidade Federal do Rio de Janeiro, COPPE. Rio de Janeiro - 2007.

73 SILVA, A. G. S. G. Estudo do comportamento eletroquímico do nióbio sob carregamentos e descarregamentos de hidrogênio. Universidade Federal do Paraná, Curitiba, 2007.

74 D'AlKaINE, C.V. et al. The Anodic Behavior of Niobium-III. Kinetics of Anodic Film Growth by Potentiodynamic and Galvanostatic Techniques - General 
Models, Equations and their Application. Corrosion Science, v.34, n.1, p.129-149, 1993.

75 AMERICAN SOCIETY FOR TESTING AND MATERIALS. Standard guide for determining mass per unit area of electrodeposited and related coating by gravimetric and other chemical analysis procedures. ASTM B767-88 (2006).

76 MORITA, T.; ASSUMPÇÃO, R. M. V. Manual de Soluções Reagentes e Solventes. Padronização - Preparação - Purificação. Editora Edgard Blucher Ltda. $2^{\mathrm{a}}$. Edição. 1972, São Paulo/SP.

77 AMERICAN SOCIETY FOR TESTING AND MATERIALS. Standard Practice for Operating Salt Spray (Fog) Apparatus. ASTM B 117 - 2009.

78 ASSOCIAÇÃO BRASILEIRA DE NORMAS TÉCNICAS. Tintas - Determinação da Aderência. ABNT NBR 11003: 2009.

79 MOLT, K.; BEHMER, D.; POHL, M. Different techniques for determining the coating weight of phosphate layers on galvanized steel by means of FT-IRspectrometry. Fresenius Journal of Analytical Chemistry (1997) 358:36-41.

80 ASSAAOUDI, H., ENNACIRI, A., RULMONT, A. Vibrational spectra of hydrated rare earth orthophosphates. Vibrational Spectroscopy 25 (2001) 81-90.

81 JEGANNATHANA, S., SANKARA NARAYANAN, T.S.N., RAVICHANDRANA K., RAJESWARI S. Formation of zinc-zinc phosphate composite coatings by cathodic electrochemical treatment. Surface \& Coatings Technology 200 (2006) 4117 - 4126.

82 FLIS, J.; TOBIYAMA, Y.; MOCHIZUKI, K.; SHIGA, C. Characterisation of phosphate coatings on zinc, zinc-nickel and mild steel by impedance measurements in dilute sodium phosphate solutions. Corrosion Science. Volume 39, Issues 10-11, October-November 1997, Pages 1757-1770.

83 VILlaS, M. R. A.; MAINIER, F. B. Processo de deposição de tintas catódicas por eletroforese e suas correlações com a qualidade e o meio ambiente. II Simpósio de Excelência em Gestão e Tecnologia - SEGeT’2005. Págs. 646-655. 
84 DE LEVIE, R. Electrochemical response of porous na rough electrodes. In: Advances in Electrochemistry and Electrochemical Engineering. V.6, New York: Delahay P., p. 329-397, 1967. Apud MENNUCCI, M. M. Estudo da Corrosão do Cobre em Meios de Sulfato e de Cloreto com Auxílio do Microeletrodo com Cavidade e de uma Microcélula. Tese Doutorado, Escola Politécnica da Universidade de São Paulo. Departamento de Engenharia Química. São Paulo, 2011, $264 \mathrm{p}$.

85 LIMA, R.C.; OLIVEIRA SOBRINHO, A. C.; JAZBINSEK, L. A. R.; CURTOLO, D. C.; BANCZEK, E. P.; COSTA, I. Efeitos da temperatura na morfologia e porosidade da camada de fosfato tricatiônico de $\mathrm{Zn}, \mathrm{Nb}, \mathrm{Mn}$, em aço carbono $\mathrm{SAE}$ 1020. In: INTERCORR 2010, Fortaleza/CE.

86 SOUZA, E. C.; TOMACHUK, C. R.; FERREIRA Jr., J. M.; COSTA, I. Investigation on the passive film formed on electrogalvanized steel by immersion in $\mathrm{Nb}$ containing solution. In: 10th International Symposium on the Passivation of Metals and Semi-Conductors and the Properties of Thin Oxide Layers - Passivity 10. Florianópolis/SC. Abril, 14/10/2011. 